\title{
A Uranium(II) Arene Complex That Acts as a Uranium(I) Synthon
}

\section{Supplementary Information}

Mark D. Straub, ${ }^{\mathrm{a}, \mathrm{b}}$ Erik T. Ouellette, ${ }^{\mathrm{a}, \mathrm{b}}$ Michael A. Boreen,${ }^{\mathrm{a}, \mathrm{b}}$ R. David Britt, ${ }^{\mathrm{c}}$ Khetpakorn Chakarawet, ${ }^{\mathrm{c}}$ Iskander Douair, ${ }^{\mathrm{e}}$ Colin A. Gould, ${ }^{\mathrm{a}}$ Laurent Maron, ${ }^{\mathrm{e}}$ Iker Del Rosal, ${ }^{\mathrm{e}}$ David Villarreal, ${ }^{\mathrm{c}}$ Stefan G. Minasian, ${ }^{\mathrm{b}}$ and John Arnold ${ }^{\mathrm{a}, \mathrm{b}}$

${ }^{a}$ Department of Chemistry, University of California, Berkeley, Berkeley, CA 94720, USA

${ }^{\mathrm{b}}$ Chemical Sciences Division, Lawrence Berkeley Laboratory, Berkeley, CA 94720, USA

${ }^{c}$ Department of Chemistry, University of California, Davis, Davis, CA, 95616, USA

${ }^{d}$ Université de Toulouse et CNRS, INSA, UPS, UMR 5215, LPCNO 135 Avenue de Rangueil, 31077 Toulouse, France

\section{Table of Contents}

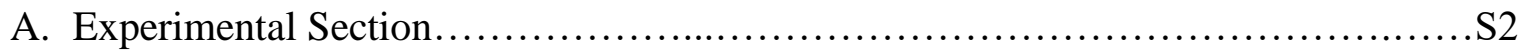

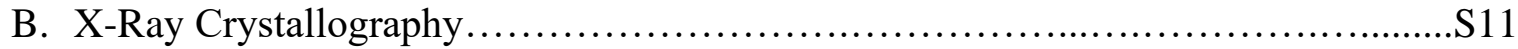

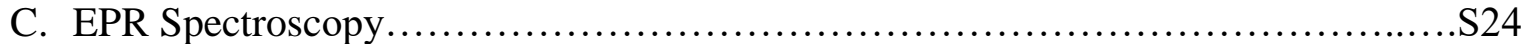

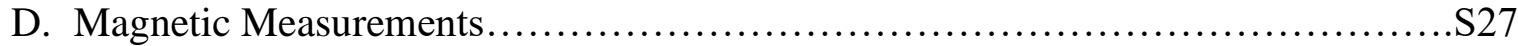

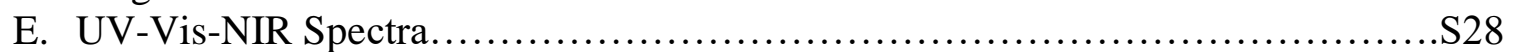

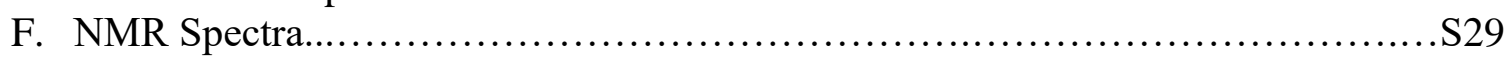

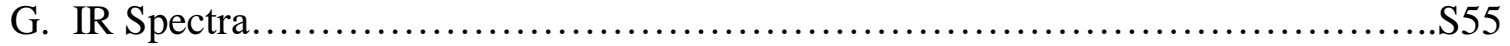

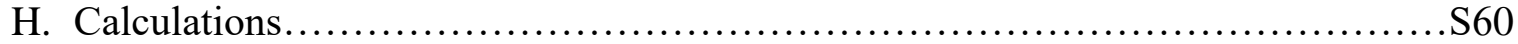

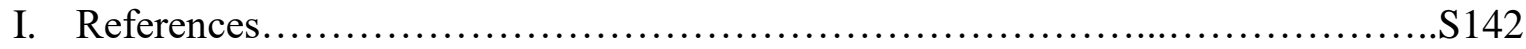




\section{A. Experimental Section}

\section{Methods and Materials}

Unless otherwise noted, all syntheses were performed using standard Schlenk techniques under an atmosphere of nitrogen or in an MBraun glovebox under an atmosphere of nitrogen. Glassware, cannulae, and Celite were stored in an oven at $160{ }^{\circ} \mathrm{C}$ for at least 12 hours prior to use. $3 \AA$ and $4 \AA$ molecular sieves were activated by heating under vacuum at $300{ }^{\circ} \mathrm{C}$ for 24 hours. Hexane, pentane, toluene, benzene, diethyl ether, tetrahydrofuran (THF), and dimethoxyethane (DME) were purified by passage through a column of activated alumina prior to use. $\mathrm{C}_{6} \mathrm{D}_{6}$ and $\mathrm{d}_{8}$-THF were purchased from Cambridge Isotope Labs, degassed with two freeze-pump-thaw cycles, and stored over $4 \AA$ molecular sieves. $\mathrm{C}_{5} \mathrm{D}_{5} \mathrm{~N}$ was purchased from Cambridge Isotope Labs, degassed with two freeze-pump-thaw cycles, and stored over $3 \AA$ molecular sieves. $\mathrm{CDCl}_{3}$ was purchased from Cambridge Isotope Labs and used as received.

$N$-(2,6-di-iso-propylphenyl)pivalamide (H(TDA)) was prepared according to literature procedures ${ }^{1}$ and purified by sublimation at $250{ }^{\circ} \mathrm{C}, 10 \mathrm{mTorr} \mathrm{ThCl}_{4}(\mathrm{DME})_{2}$ and $\mathrm{U}\left(\mathrm{N}\left(\mathrm{SiMe}_{3}\right)_{2}\right)_{3}$ were synthesized according to literature procedures. ${ }^{2,3}$ Unless otherwise specified, all other chemicals were purchased from Sigma-Aldrich or Acros Organics and used as received. ${ }^{1} \mathrm{H}$ and ${ }^{13} \mathrm{C}$ NMR spectra were recorded at room temperature using Bruker AV-600, AV-500, AVB-400, AVQ-400, and AV-300 spectrometers at room temperature unless otherwise specified. Variable temperature (VT) NMR spectra were collected on an AV-500 spectrometer, and temperatures were calibrated using a solution of $20 \%$ ethylene glycol in MeOD. ${ }^{1} \mathrm{H}$ chemical shifts were referenced to $\mathrm{C}_{6} \mathrm{D}_{5} \mathrm{H}(\delta=7.16 \mathrm{ppm}), \mathrm{C}_{4} \mathrm{D}_{7} \mathrm{HO}\left(\delta_{1}=3.58 \mathrm{ppm}\right), \mathrm{C}_{5} \mathrm{D}_{4} \mathrm{HN}\left(\delta_{1}=8.74 \mathrm{ppm}\right)$, and $\mathrm{CHCl}_{3}(\delta=7.26 \mathrm{ppm}) .{ }^{13} \mathrm{C}$ chemical shifts were referenced to $\mathrm{C}_{6} \mathrm{D}_{6}(\delta=128.39 \mathrm{ppm})$ and $\mathrm{C}_{5} \mathrm{D}_{5} \mathrm{~N}$ $\left(\delta_{1}=150.35 \mathrm{ppm}\right)$. Samples for IR spectroscopy were prepared as Nujol mulls, and spectra were taken in $\mathrm{KBr}$ plates using a Nicolet iS10 spectrometer. UV-vis-NIR spectra were collected using a Varian Cary 5000 UV-Vis-NIR spectrophotometer within the wavelength range of 300 to 1600 nm. A $1 \mathrm{~cm}$ path length quartz cell was used for UV-Vis-NIR measurements on solution samples, and a solvent blank was subtracted from each run. Melting points were determined in sealed tubes under an atmosphere of nitrogen using a Stanford Research Systems OptiMelt instrument and are reported uncorrected. Magnetic susceptibility measurements were collected using a Quantum Design MPMS2 SQUID magnetometer. 


\section{Synthesis of Compounds}

K(TDA): A THF solution (100 mL) of $\mathrm{KN}\left(\mathrm{SiMe}_{3}\right)_{2}(3.84 \mathrm{~g}, 19.3 \mathrm{mmol})$ was added to a stirred THF solution $(150 \mathrm{~mL})$ of $\mathrm{H}(\mathrm{TDA})(5.00 \mathrm{~g}, 19.1 \mathrm{mmol})$ maintained at $-78{ }^{\circ} \mathrm{C}$ via cannula. The resulting solution was slowly warmed to room temperature and stirred for $2 \mathrm{~d}$, then the solvent was removed in vacuo to give an off-white powder. This powder was washed with hexane (50 $\mathrm{mL}$ ) to remove impurities, then the solvent was removed in vacuo to give the product as a colorless powder (4.94 g, 86\% yield).

${ }^{1} \mathrm{H}$ NMR $\left(\mathrm{C}_{5} \mathrm{D}_{5} \mathrm{~N}, 400 \mathrm{MHz}\right): \delta 7.17$ (d, 2H, Ar- $H$ ), 6.99 (t, $\left.1 \mathrm{H}, \mathrm{Ar}-H\right), 3.77\left(\mathrm{~m}, 2 \mathrm{H}, \mathrm{CH}\left(\mathrm{CH}_{3}\right)_{2}\right.$, $1.68\left(\mathrm{~s}, 9 \mathrm{H}, \mathrm{C}\left(\mathrm{CH}_{3}\right)_{3}\right), 1.32$ and $1.26\left(\mathrm{dd}, 12 \mathrm{H}, \mathrm{CH}\left(\mathrm{CH}_{3}\right)_{2}\right)$.

${ }^{13} \mathrm{C} \mathrm{NMR}\left(\mathrm{C}_{5} \mathrm{D}_{5} \mathrm{~N}, 600 \mathrm{MHz}\right): \delta 176.48(\mathrm{NCO}), 155.37(\mathrm{CCN}), 141.61(\mathrm{Ar}), 122.91(\mathrm{Ar}), 120.22$ (Ar), $39.80\left(C\left(\mathrm{CH}_{3}\right)_{3}\right), 30.82\left(\mathrm{C}\left(\mathrm{CH}_{3}\right)_{3}\right), 28.80\left(\mathrm{CH}\left(\mathrm{CH}_{3}\right)_{2}\right), 24.00\left(\mathrm{CH}\left(\mathrm{CH}_{3}\right)_{2}\right)$.

IR (cm $\left.{ }^{-1}\right): 1586(\mathrm{w}), 1542$ (s), 1517 (s), 1433 (s), 1390 (m), 1349 (s), 1317 (m), 1255 (m), 1219 (m), $1176(w), 1158(w), 1101(w), 1056(w), 1041(w), 914(m), 883(w), 848(w), 808(w), 791$ (m), $751(\mathrm{~s})$.

Melting point: $148-150{ }^{\circ} \mathrm{C}$; vaporizes slowly above this temperature.

K(TDA)(THF)[2.2.2]cryptand: A THF solution (2 mL) of [2.2.2]cryptand (26 mg, 0.069 mmol) was added to a stirred THF solution $(2 \mathrm{~mL})$ of $\mathrm{K}(\mathrm{TDA})(24 \mathrm{mg}, 0.080 \mathrm{mmol})$. The resulting solution was stirred for $2 \mathrm{~h}$, then the solvent was removed in vacuo to give a colorless oil, which was triturated with hexane $(2 \mathrm{~mL})$. This material was extracted into $\mathrm{Et}_{2} \mathrm{O}(3 \mathrm{~mL})$ and filtered, then the solvent was removed in vacuo to give a colorless oil. This oil was triturated twice with hexane $(2 \mathrm{~mL})$ and the solvent was removed in vacuo to give the final product as a colorless solid. (44 mg, 94\% yield).

${ }^{1} \mathrm{H}$ NMR $\left(\mathrm{C}_{6} \mathrm{D}_{6}, 600 \mathrm{MHz}\right): \delta 7.28(\mathrm{~d}, 2 \mathrm{H}, \mathrm{Ar}-H), 7.04(\mathrm{t}, 1 \mathrm{H}, \mathrm{Ar}-H), 3.97\left(\mathrm{~m}, 2 \mathrm{H}, \mathrm{CH}\left(\mathrm{CH}_{3}\right)_{2}\right.$, 3.15 (s, 12H, cryptand), 3.07 (t, 12H, cryptand), 2.14 (t, 12H, cryptand), $1.88\left(\mathrm{~s}, 9 \mathrm{H}, \mathrm{C}\left(\mathrm{CH}_{3}\right)_{3}\right)$, 1.59 (d, 12H, $\left.\mathrm{CH}\left(\mathrm{CH}_{3}\right)_{2}\right)$. 
${ }^{13} \mathrm{C}$ NMR $\left(\mathrm{C}_{6} \mathrm{D}_{6}, 600 \mathrm{MHz}\right): \delta 156.45$ (Ar), 141.21 (Ar), 121.93 (Ar), 70.65 (cryptand), 68.37 (cryptand), 54.99 (cryptand), $40.12\left(\mathrm{C}_{\left.\left(\mathrm{CH}_{3}\right)_{3}\right),} 31.36\left(\mathrm{C}\left(\mathrm{CH}_{3}\right)_{3}\right), 29.23\left(\mathrm{CH}\left(\mathrm{CH}_{3}\right)_{2}\right), 24.47\right.$ $\left(\mathrm{CH}\left(\mathrm{CH}_{3}\right)_{2}\right)$. The amidate backbone peak and one aryl peak are very low intensity in the ${ }^{13} \mathrm{C}$ NMR spectra of this compound and cannot be seen clearly above the baseline.

IR (cm $\left.{ }^{-1}\right): 1588(\mathrm{w}), 1540(\mathrm{~s}), 1428(\mathrm{~m}), 1388(\mathrm{~m}), 1355(\mathrm{~m}), 1297(\mathrm{w}), 1258(\mathrm{~m}), 1133(\mathrm{~m})$, 1104 (s), 1080 (m), 950 (m), 932 (m), 907 (w), 830 (w), 780 (w), 749 (w), 734 (m).

[K[2.2.2]cryptand][U(TDA)4] (1-crypt): All solvents and glassware were cooled to $-40{ }^{\circ} \mathrm{C}$ for the duration of the synthesis and workup of this compound. A purple DME solution (1 mL) of 2 (49 $\mathrm{mg}, 0.048 \mathrm{mmol})$ and [2.2.2]cryptand $(18 \mathrm{mg}, 0.048 \mathrm{mmol})$ was filtered through a pipette containing $\mathrm{KC}_{8}(26 \mathrm{mg}, 0.192 \mathrm{mmol})$ layered on Celite over the course of $1 \mathrm{~min}$, resulting in formation of a reddish-brown solution. The solvent was promptly removed in vacuo, and the remaining maroon solids were washed with hexane $(2 \mathrm{~mL})$, then $\mathrm{Et}_{2} \mathrm{O}(2 \mathrm{~mL})$. The product was extracted into THF (2 mL) and filtered, then the solvent was removed in vacuo to give the product as a maroon solid (29 $\mathrm{mg}, 49 \%$ yield).

${ }^{1} \mathrm{H}$ NMR (d8-THF, $600 \mathrm{MHz}$ ): $\delta 6.07$ (broad), 3.50 (s, 12H, cryptand), 3.52 (t, 12H, cryptand), 2.56 (t, 12H, cryptand), 0.87 (broad), -0.54 (broad), -1.76 (broad).

IR (cm $\left.{ }^{-1}\right)$ : 1613 (m), 1585 (m), 1355 (m), 1329 (w), 1293 (m), 1259 (w), 1208 (m), 1158 (m), $1134(\mathrm{w}), 1105$ (m), 1078 (w), 952 (w), 933 (w), 912 (m), 833 (w), 807 (w), 783 (w), 740 (m), $561(\mathrm{w}), 526(\mathrm{w})$.

We have previously reported full characterization of the closely-related complex [K(18-crown-6)][U(TDA) $)_{4}$ (1-crown). ${ }^{4}$

U(TDA)3 (2): H(TDA) (903 $\mathrm{mg}, 3.45 \mathrm{mmol}$ ) was added to a hexane solution (10 $\mathrm{mL})$ of $\mathrm{U}\left(\mathrm{N}\left(\mathrm{SiMe}_{3}\right)_{2}\right)_{3}(803 \mathrm{mg}, 1.12 \mathrm{mmol})$ cooled to $-40{ }^{\circ} \mathrm{C}$. The dark purple solution was allowed to warm to room temperature and stirred for $16 \mathrm{~h}$, then the solvent was removed in vacuo, and the 
product was extracted into pentane $(35 \mathrm{~mL})$. The resulting colorless solution was filtered and cooled to $-40{ }^{\circ} \mathrm{C}$, yielding dark purple crystals (794 $\mathrm{mg}, 68 \%$ yield).

${ }^{1} \mathrm{H}$ NMR (C6 $\mathrm{D}_{6}, 600 \mathrm{MHz}$ ): $\delta 15.74$ (s), 11.11 (s), 9.66 (broad), 4.58 (s), 2.90 to -0.90 (broad, multiple resonances), $-3.44(\mathrm{~s}),-10.63$ (s), -12.48 (s), -17.39 (s), -22.28 (s).

IR ( $\left.\mathrm{cm}^{-1}\right)$ : $1648(\mathrm{w}), 1541$ (s), 1477 (m), $1420(\mathrm{w}), 1394$ (w), $1362(\mathrm{w}), 1333$ (m), 1312 (m), 1253 (w), 1214 (m), 1170 (m), 1106 (w), 1052 (w), 1041 (w), 1028 (w), 935 (w), 918 (w), 882 (w), $845(\mathrm{w}), 836(\mathrm{w}), 802(\mathrm{w}), 768(\mathrm{w}), 762(\mathrm{w}), 749(\mathrm{w}), 736(\mathrm{w}), 653(\mathrm{w}), 627(\mathrm{w}), 601(\mathrm{w})$, $583(\mathrm{w}), 564(\mathrm{w}), 541(\mathrm{w}), 516(\mathrm{w})$.

EA calcd for $\mathrm{C}_{51} \mathrm{H}_{78} \mathrm{~N}_{3} \mathrm{O}_{3} \mathrm{U}: \mathrm{C}: 60.10 \%, \mathrm{H}: 7.71 \%$, N: 4.12\%. Found: C: $60.33 \%, \mathrm{H}: 7.48 \%$, N: $3.91 \%$.

Melting point: decomposes $\mathrm{ca} .80^{\circ} \mathrm{C}$.

[K[2.2.2]cryptand][U(TDA) 2$]$ (3): All solvents, reagents, and glassware were cooled to $-40{ }^{\circ} \mathrm{C}$ for the duration of the synthesis and workup of this compound. A THF suspension ( $1 \mathrm{~mL})$ of $\mathrm{KC}_{8}(52 \mathrm{mg}, 0.385 \mathrm{mmol})$ was added dropwise to a THF solution (1 mL) of 2 (99 mg, 0.097 $\mathrm{mmol})$ and [2.2.2]cryptand $(73 \mathrm{mg}, 0.194 \mathrm{mmol})$. Upon addition of $\mathrm{KC}_{8}$, the purple solution immediately turned reddish-brown. The solvent was promptly removed in vacuo and the remaining dark brown solids were washed with hexane $(2 \mathrm{~mL})$, then $\mathrm{Et}_{2} \mathrm{O}(2 \mathrm{~mL})$. The product was then extracted into DME (2 mL) and filtered, then the solvent was removed in vacuo to give the product as a dark brown solid (47 $\mathrm{mg}, 41 \%$ yield). Similar yields were obtained when DME was used in place of THF as the reaction solvent.

Formation of $\mathbf{3}$ required an excess of $\mathrm{KC}_{8}$ and two equivalents of [2.2.2]cryptand; when either reagent was reduced to one equivalent, only 1-crypt could be isolated from the reaction mixture. Although this second equivalent of [2.2.2]cryptand does not incorporate into the structure of $\mathbf{3}$, we observed the formation of K(TDA)[2.2.2]cryptand when two equivalents of [2.2.2]cryptand were used. However, when only one equivalent of [2.2.2]cryptand was used, we saw no formation of $\mathrm{K}(\mathrm{TDA})$ or $\mathrm{K}(\mathrm{TDA})[2.2 .2]$ cryptand. These results suggest that coordination of 
[2.2.2]cryptand may help facilitate the loss of potassium amidate along the pathway to forming $\mathbf{3}$ from 2.

${ }^{1} \mathrm{H}$ NMR (d8-THF, $\left.600 \mathrm{MHz}\right): \delta 12.98\left(\mathrm{~s}, 2 \mathrm{H}, \mathrm{CH}\left(\mathrm{CH}_{3}\right)_{2}\right), 7.33\left(\mathrm{~s}, 2 \mathrm{H}, \mathrm{CH}\left(\mathrm{CH}_{3}\right)_{2}\right), 3.79$ (s, 12H, cryptand), 3.73 (t, 12H, cryptand), 3.59 (s, 6H, $\left.\mathrm{CH}\left(\mathrm{CH}_{3}\right)_{2}\right), 2.72$ (t, 12H, cryptand), 1.66 (d, 6H, $\left.\mathrm{CH}\left(\mathrm{CH}_{3}\right)_{2}\right), 0.73\left(\mathrm{~s}, 18 \mathrm{H}, \mathrm{C}\left(\mathrm{CH}_{3}\right)_{3}\right),-2.08\left(\mathrm{~s}, 6 \mathrm{H}, \mathrm{CH}\left(\mathrm{CH}_{3}\right)_{2}\right),-3.18\left(\mathrm{~s}, 6 \mathrm{H}, \mathrm{CH}\left(\mathrm{CH}_{3}\right)_{2}\right), \quad-14.71$ (s, 2H, Ar-H), -18.65 (s, 2H, Ar-H), -21.51 (s, 2H, Ar-H).

IR ( $\left.\mathrm{cm}^{-1}\right): 1587(\mathrm{w}), 1541(\mathrm{~m}), 1428(\mathrm{~m}), 1388(\mathrm{~m}), 1355$ (m), $1297(\mathrm{w}), 1259$ (w), $1132(\mathrm{~m})$, $1103(\mathrm{~m}), 1080(\mathrm{~m}), 950(\mathrm{~m}), 932(\mathrm{w}), 906$ (w), $930(\mathrm{w}), 779(\mathrm{w}), 751(\mathrm{w}), 734(\mathrm{w}), 525(\mathrm{w})$.

EA calcd for $\mathrm{C}_{52} \mathrm{H}_{88} \mathrm{KN}_{4} \mathrm{O}_{8} \mathrm{U}: \mathrm{C}: 53.18 \%, \mathrm{H}: 7.55 \%$, N: $4.77 \%$. Found: C: $52.99 \%$, H: 7.69\%, $\mathrm{N}: 4.78 \%$.

Melting point: decomposes at room temperature.

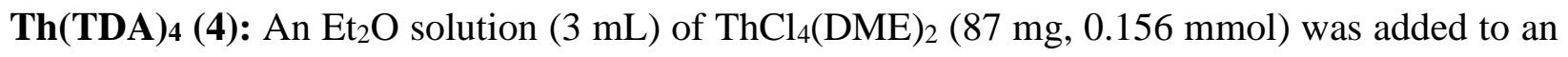
$\mathrm{Et}_{2} \mathrm{O}$ solution $(4 \mathrm{~mL})$ of $\mathrm{K}(\mathrm{TDA})(188 \mathrm{mg}, 0.625 \mathrm{mmol})$ dropwise. The colorless solution turned cloudy over the course of the reaction. The solution was stirred for $7 \mathrm{~d}$, then the solvent was removed in vacuo and the product was extracted into $\mathrm{Et}_{2} \mathrm{O}(10 \mathrm{~mL})$. The resulting colorless solution was filtered to remove $\mathrm{KCl}$, concentrated to $5 \mathrm{~mL}$, and cooled to $-40{ }^{\circ} \mathrm{C}$, yielding colorless crystals (151 mg, $77 \%$ yield).

${ }^{1} \mathrm{H}$ NMR $\left(\mathrm{C}_{6} \mathrm{D}_{6}, 600 \mathrm{MHz}\right): \delta 7.11(\mathrm{~m}, 12 \mathrm{H}, \mathrm{Ar}-H), 6.99(\mathrm{t}, 1 \mathrm{H}, \mathrm{Ar}-H), 3.43\left(\mathrm{~m}, 8 \mathrm{H}, \mathrm{CH}\left(\mathrm{CH}_{3}\right)_{2}\right.$, $1.30\left(\mathrm{~s}, 36 \mathrm{H}, \mathrm{C}\left(\mathrm{CH}_{3}\right)_{3}\right), 1.00\left(\mathrm{~d}, 48 \mathrm{H}, \mathrm{CH}\left(\mathrm{CH}_{3}\right)_{2}\right)$.

${ }^{13} \mathrm{C}$ NMR $\left(\mathrm{C}_{6} \mathrm{D}_{6}, 600 \mathrm{MHz}\right): \delta 183.27(\mathrm{NCO}), 142.10(\mathrm{CCN}), 140.85$ (Ar), 124.55 (Ar), 122.86

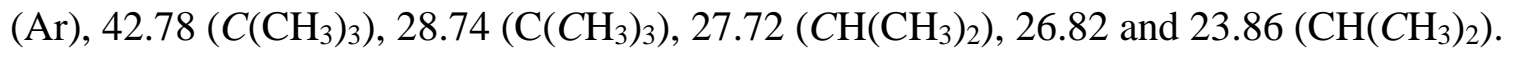

IR ( $\left.\mathrm{cm}^{-1}\right)$ : 1537 (m), $1524(\mathrm{~m}), 1397$ (m), 1365 (w), 1312 (m), 1255 (w), 1215 (m), 1170 (m), 1115 (w), 1106 (w), 1056 (w), 1044 (w), 1031 (w), 929 (w), 913 (w), 842 (w), 832 (w), 802 (w), $762(\mathrm{~m}), 735(\mathrm{w}), 613(\mathrm{w}), 582(\mathrm{w}), 517(\mathrm{w})$. 
EA calcd for $\mathrm{C}_{68} \mathrm{H}_{104} \mathrm{~N}_{4} \mathrm{O}_{4}$ Th: C: $64.13 \%, \mathrm{H}: 8.23 \%$, N: 4.40\%. Found: C: $64.28 \%, \mathrm{H}: 8.43 \%$, $\mathrm{N}: 4.32 \%$.

Melting point: decomposes $c a .367^{\circ} \mathrm{C}$.

[K[2.2.2]cryptand][Th(TDA) 3 (THF)] (5): All solvents, reagents, and glassware were cooled to $-40{ }^{\circ} \mathrm{C}$ for the duration of the synthesis and workup of this compound. A THF suspension (1 $\mathrm{mL})$ of $\mathrm{KC}_{8}(11 \mathrm{mg}, 0.079 \mathrm{mmol})$ was added dropwise to a THF solution $(2 \mathrm{~mL})$ of 4 (47 mg, $0.037 \mathrm{mmol}$ ) and [2.2.2]cryptand (14 $\mathrm{mg}, 0.037 \mathrm{mmol})$, causing the colorless solution to turn red-orange. The solution was stirred for $15 \mathrm{~min}$, then the solvent was removed in vacuo and the resulting red solids were washed with hexane $(3 \mathrm{~mL})$. The product was then extracted into $\mathrm{Et}_{2} \mathrm{O}$ $(2 \mathrm{~mL})$ and filtered, then the solvent was removed in vacuo to give a red solid, which was washed once more with hexane $(3 \mathrm{~mL})(54 \mathrm{mg}, 98 \%$ yield). Crystals suitable for x-ray diffraction were grown by slow evaporation of an $\mathrm{Et}_{2} \mathrm{O}$ solution at $-40^{\circ} \mathrm{C}$.

${ }^{1} \mathrm{H}$ NMR ( $\mathrm{C}_{6} \mathrm{D}_{6}, 500 \mathrm{MHz}$ ): $\delta 7.32$ (s), 7.26 (s), 7.20 (d), 7.14 (s), 7.00 to $7.11(\mathrm{~m}), 6.95$ (s), 3.65 (m), 3.58 (t, $4 \mathrm{H}, \mathrm{CH}_{2} \mathrm{CH}_{2} \mathrm{O}$ ), 3.19 (s), 3.16 (s, 12H, cryptand), 2.99 to $3.13(\mathrm{~m}), 3.09$ (t, $12 \mathrm{H}$, cryptand), $2.16\left(\mathrm{~m}, 4 \mathrm{H}, \mathrm{CH}_{2} \mathrm{CH}_{2} \mathrm{O}\right.$ ), 2.11 (t, 12H, cryptand), 1.20 to 2.01 (m), 1.19 (d), 1.08 (s), $1.00(\mathrm{~s})$.

${ }^{13} \mathrm{C}$ NMR $\left(\mathrm{C}_{6} \mathrm{D}_{6}, 600 \mathrm{MHz}\right): \delta 141.63(\mathrm{CCN}), 140.85(\mathrm{Ar}), 125.33(\mathrm{Ar}), 123.64(\mathrm{Ar}), 122.80$ (Ar), $70.79\left(\mathrm{CH}_{2} \mathrm{CH}_{2} \mathrm{O}\right), 70.83$ (cryptand), 67.90 (cryptand), 54.13 (cryptand), 43.55, 30.59, $30.46,29.49,28.76,28.48,28.38,27.60,26.94,24.43,24.32,23.88$.

IR $\left(\mathrm{cm}^{-1}\right)$ : 1614 (w), 1583 (w), 1540 (w), $1361(\mathrm{w}), 1296$ (w), 1258 (w), $1210(\mathrm{w}), 1134(\mathrm{w})$, 1105 (m), 1078 (w), 1056 (w), 1027 (w), 950 (w), 932 (w), 910 (w), 882 (w), 831 (w), 803 (w), $764(\mathrm{w}), 740(\mathrm{w}), 650(\mathrm{w}), 583(\mathrm{w}), 524(\mathrm{w})$.

EA calcd for $\mathrm{C}_{63} \mathrm{H}_{103} \mathrm{KN}_{4} \mathrm{O}_{9} \mathrm{U}: \mathrm{C}: 56.57 \%$, $\mathrm{H}: 7.76 \%$, N: $4.19 \%$. Found: C: $56.23 \%$, H: $7.58 \%$, $\mathrm{N}: 4.00 \%$.

Melting point: decomposes at room temperature. 
[K[2.2.2]cryptand][(UI(TDA) $\left.\left.)_{2}\right)_{2}(\boldsymbol{\mu}-\mathrm{I})\right](\mathbf{6})$ : All solvents, reagents, and glassware were cooled to $-40{ }^{\circ} \mathrm{C}$ for the duration of the synthesis and workup of this compound. A THF solution $(0.5 \mathrm{~mL})$ of $\mathrm{I}_{2}(6.9 \mathrm{mg}, 0.027 \mathrm{mmol})$ was added dropwise to a THF solution ( $\left.1 \mathrm{~mL}\right)$ of $\mathbf{3}$ (35 mg, 0.030 $\mathrm{mmol}$ ), causing the dark brown solution to turn dark purple. The solution was stirred for $10 \mathrm{~min}$, then the solvent was removed in vacuo and the resulting purple solids were extracted into $\mathrm{Et}_{2} \mathrm{O}$ $(2 \mathrm{~mL})$. The resulting blue-purple solution was filtered, concentrated to $0.5 \mathrm{~mL}$, and cooled, yielding dark blue crystals ( $24 \mathrm{mg}, 76 \%$ yield).

${ }^{1} \mathrm{H}$ NMR (d8-THF, $\left.600 \mathrm{MHz}\right): \delta 37.50$ (s), 35.94 (s), 25.45 (s), 23.94 (s), 21.96 (s), 19.81 (s), 18.37 (s), 16.51 (s), 15.95 (s), 14.93 (s), 11.88 (s), 11.51 (s), 10.35 (s), 10.09 (s), 7.86 (s), 7.78 (s), $7.57(\mathrm{~s}), 6.90(\mathrm{~s}), 5.84(\mathrm{~s}), 5.63(\mathrm{~s}), 5.38(\mathrm{~s}), 4.18(\mathrm{~s}), 3.59(\mathrm{~s}), 2.95(\mathrm{~s}), 1.93(\mathrm{~s}), 1.44(\mathrm{~s}), 0.77$ $(\mathrm{s}), 0.58(\mathrm{~s}),-0.46(\mathrm{~s}),-1.10(\mathrm{~d}),-2.07(\mathrm{~s}),-2.53(\mathrm{~s}),-3.15(\mathrm{~s}),-3.33(\mathrm{~s}),-3.47(\mathrm{~s}),-4.83(\mathrm{~s}),-$ $5.49(\mathrm{~s}), \quad-6.45(\mathrm{~s}),-6.65(\mathrm{~s}),-7.60(\mathrm{~s}),-8.55(\mathrm{~s}),-9.72(\mathrm{~s}),-11.29(\mathrm{~s}),-12.61(\mathrm{~s}),-13.44(\mathrm{~s})$, $-15.46(\mathrm{~s}), \quad-17.63(\mathrm{~s}),-17.96(\mathrm{~s}),-18.59(\mathrm{~s}),-20.89(\mathrm{~s}),-27.47(\mathrm{~s}),-30.92(\mathrm{~s}),-31.69(\mathrm{~s}),-$ $36.09(\mathrm{~s}),-37.77(\mathrm{~s}),-46.12(\mathrm{~s}),-47.54(\mathrm{~s})$.

IR $\left(\mathrm{cm}^{-1}\right)$ : 1563 (w), $1551(\mathrm{~m}), 1513(\mathrm{~m}), 1399$ (w), $1355(\mathrm{~m}), 1304(\mathrm{~m}), 1258(\mathrm{w}), 1217(\mathrm{w})$, 1211 (w), 1170 (m), 1132 (w), 1106 (m), 1084 (w), 1054 (w), 1040 (w), 1030 (w), 947 (w), 931 (w), $921(w), 832(w), 805(w), 766(m), 738(w), 633(w), 588(w), 573(w), 520(w)$.

EA calcd for $\mathrm{C}_{86} \mathrm{H}_{138} \mathrm{I}_{3} \mathrm{KN}_{6} \mathrm{O}_{10} \mathrm{U}_{2}: \mathrm{C}: 44.68 \%$, H: $6.02 \%$, N: $3.64 \%$. Found: C: $45.02 \%, \mathrm{H}$ : $6.34 \%, \mathrm{~N}: 3.45 \%$.

Melting point: decomposes $c a .95^{\circ} \mathrm{C}$.

[K[2.2.2]cryptand $]\left[\mathbf{U}\left(\boldsymbol{\eta}^{7}-\mathbf{C}_{7} \mathbf{H}_{7}\right)(\text { TDA })_{2}(\right.$ THF $\left.)\right](7)$ : All solvents, reagents, and glassware were cooled to $-40^{\circ} \mathrm{C}$ for the duration of the synthesis and workup of this compound. A THF solution $(0.4 \mathrm{~mL})$ of cycloheptatriene $(3.9 \mathrm{mg}, 0.043 \mathrm{mmol})$ was added dropwise to a THF solution (1 $\mathrm{mL})$ of $\mathbf{3}(50 \mathrm{mg}, 0.043 \mathrm{mmol})$, causing the dark brown solution to turn maroon. The solution was stirred for $20 \mathrm{~min}$, then the solvent was removed in vасио and the resulting maroon solids were washed with hexane $(3 \mathrm{~mL})$. The product was extracted into THF $(1 \mathrm{~mL})$ and $\mathrm{Et}_{2} \mathrm{O}(4 \mathrm{~mL})$, 
filtered, concentrated to $3 \mathrm{~mL}$, and stored at $-40{ }^{\circ} \mathrm{C}$, yielding maroon crystals $(30 \mathrm{mg}, 53 \%$ yield).

${ }^{1} \mathrm{H}$ NMR (d8-THF, $\left.400 \mathrm{MHz}\right): \delta 7.04$ (s, 4H, Ar-H), 6.72 (s, 2H, $\left.\mathrm{Ar}-H\right), 5.60$ (s, 18H, $\left.\mathrm{C}\left(\mathrm{CH}_{3}\right)_{3}\right)$, 4.53 (s, 12H, cryptand), 4.40 (s, $12 \mathrm{H}$, cryptand), $3.60\left(\mathrm{~m}, 4 \mathrm{H}, \mathrm{CH}_{2} \mathrm{CH}_{2} \mathrm{O}\right), 1.77(\mathrm{~m}, 4 \mathrm{H}$, $\mathrm{CH}_{2} \mathrm{CH}_{2} \mathrm{O}$ ), 1.39 (s, $\left.4 \mathrm{H}, \mathrm{CH}\left(\mathrm{CH}_{3}\right)_{2}\right), 1.15$ (s, $12 \mathrm{H}$, cryptand), -2.61 (broad, $\left.24 \mathrm{H}, \mathrm{CH}\left(\mathrm{CH}_{3}\right)_{2}\right)$, $-47.90\left(\mathrm{~s}, 7 \mathrm{H}, \mathrm{C}_{7} \mathrm{H}_{7}\right)$. Direct observation of $\mathrm{H}_{2}$ formation by ${ }^{1} \mathrm{H}$ NMR was precluded by the peak at $4.53 \mathrm{ppm}$.

IR ( $\left.\mathrm{cm}^{-1}\right)$ : 1599 (w), 1579 (w), 1364 (w), 1355 (w), 1331 (w), 1298 (w), 1260 (w), $1214(\mathrm{w})$, $1160(w), 1138(w), 1104(m), 1079(w), 1030(w), 950(w), 931(w), 911(w), 832(w), 740(w)$, $562(\mathrm{w})$.

EA calcd for $\mathrm{C}_{63} \mathrm{H}_{103} \mathrm{KN}_{4} \mathrm{O}_{9} \mathrm{U}: \mathrm{C}: 56.57 \%$, $\mathrm{H}: 7.76 \%$, N: 4.19\%. Found: C: $56.23 \%, \mathrm{H}: 7.58 \%$, $\mathrm{N}: 4.00 \%$.

Melting point: decomposes $c a .70{ }^{\circ} \mathrm{C}$.

[U(TDA) $\left.]_{2}\right]_{2}\left(\boldsymbol{\mu}-\boldsymbol{\eta}^{\mathbf{8}}: \boldsymbol{\eta}^{3}-\mathbf{C}_{\mathbf{8}} \mathbf{H}_{\mathbf{8}}\right)(\mathbf{8})$ : A THF solution $(0.5 \mathrm{~mL})$ of cyclooctatetraene (5.1 mg, 0.049 $\mathrm{mmol}$ ) cooled to $-40{ }^{\circ} \mathrm{C}$ was added dropwise to a THF solution $(2 \mathrm{~mL})$ of $2(50 \mathrm{mg}, 0.049 \mathrm{mmol})$ cooled to $-40{ }^{\circ} \mathrm{C}$, causing the purple-brown solution to turn yellow. The solution was stirred for $15 \mathrm{~min}$, then the solvent was removed in vacuo and the resulting yellow solids were triturated with hexane $(2 \mathrm{~mL})$. The product was extracted into pentane $(6 \mathrm{~mL})$, filtered, concentrated to 3 $\mathrm{mL}$, and cooled to $-40{ }^{\circ} \mathrm{C}$, yielding yellow crystals. $(53 \mathrm{mg}, 98 \%$ yield)

${ }^{1} \mathrm{H}$ NMR ( $\left.\mathrm{C}_{6} \mathrm{D}_{6}, 600 \mathrm{MHz}\right): \delta 34.26$ (broad), 6.23 (broad), 1.72 (broad), -1.82 (broad), -4.92 (broad), -19.34 (broad), -47.98 (s, $\left.8 \mathrm{H}, \mathrm{C}_{8} \mathrm{H}_{8}\right)$.

IR ( $\left.\mathrm{cm}^{-1}\right)$ : $1634(\mathrm{~m}), 1590$ (w), 1533 (w), 1397 (w), $1334(\mathrm{w}), 1309$ (w), $1265(\mathrm{w}), 1206(\mathrm{w})$, $1173(w), 1154(w), 1123(\mathrm{~m}), 1095(\mathrm{~m}), 1027(\mathrm{w}), 923(\mathrm{w}), 906(\mathrm{w}), 831(\mathrm{w}), 803(\mathrm{w}), 766(\mathrm{w})$, $758(w), 742(\mathrm{~m}), 657(\mathrm{w}), 593(\mathrm{w}), 570(\mathrm{w})$.

EA calcd for $\mathrm{C}_{110} \mathrm{H}_{164} \mathrm{~N}_{6} \mathrm{O}_{6} \mathrm{U}_{2}:$ C: $61.66 \%, \mathrm{H}: 7.71 \%$, N: $3.92 \%$. Found: C: $61.59 \%, \mathrm{H}: 7.78 \%$, $\mathrm{N}: 3.78 \%$. 
Melting point: decomposes $c a .145^{\circ} \mathrm{C}$.

Reaction of (3) with [FeCp2][B( $\left.\left.\mathbf{C}_{6} \mathbf{F}_{5}\right)_{4}\right]$ : All solvents, reagents, and glassware were cooled to $-40{ }^{\circ} \mathrm{C}$ for this reaction. An $\mathrm{Et}_{2} \mathrm{O}$ suspension $(2 \mathrm{~mL})$ of $\left[\mathrm{FeCp}_{2}\right]\left[\mathrm{B}\left(\mathrm{C}_{6} \mathrm{~F}_{5}\right)_{4}\right](18 \mathrm{mg}, 0.021 \mathrm{mmol})$ was added to an $\mathrm{Et}_{2} \mathrm{O}$ solution $(1 \mathrm{~mL})$ of $\mathbf{3}(25 \mathrm{mg}, 0.021 \mathrm{mmol})$ dropwise, causing the dark brown solution to turn dark red. This solution was stirred for 5 minutes, then the solvent was removed in vacuo to give a dark red solid. Hexane $(2 \mathrm{~mL})$ was added and the resulting yellow solution of $\mathrm{FeCp}_{2}$ was transferred to a separate vial. $\mathrm{Et}_{2} \mathrm{O}(2 \mathrm{~mL})$ was then added to the hexaneinsoluble red solids, giving a red solution; this was filtered and concentrated to a volume of 1 $\mathrm{mL}$. Red crystals of the product were grown by slow evaporation of $\mathrm{Et}_{2} \mathrm{O}$ at $-40{ }^{\circ} \mathrm{C} .{ }^{1} \mathrm{H}$ NMR spectroscopy revealed these to be $[\mathrm{K}[2.2 .2]$ cryptand][U(TDA) 4 ( $(9 \mathrm{mg}, 25 \%$ yield), and the yellow hexane fraction was found to contain primarily $\mathrm{FeCp}_{2}$, which was observed as a singlet in the ${ }^{1} \mathrm{H}$ NMR spectrum at $4.01 \mathrm{ppm}\left(\mathrm{C}_{6} \mathrm{D}_{6}\right)$.

Reaction of (5) with $\left[\mathbf{F e C p}_{2}\right] \mathbf{B}\left(\mathbf{C}_{6} \mathbf{F}_{5}\right)_{4}$ : An $\mathrm{Et}_{2} \mathrm{O}$ suspension $(2 \mathrm{~mL})$ of $\left[\mathrm{FeCp}_{2}\right] \mathrm{B}\left(\mathrm{C}_{6} \mathrm{~F}_{5}\right)_{4}(29 \mathrm{mg}$, $0.033 \mathrm{mmol}$ ) was added to an $\mathrm{Et}_{2} \mathrm{O}$ solution $(1 \mathrm{~mL})$ of $5(50 \mathrm{mg}, 0.033 \mathrm{mmol})$ dropwise. The resulting yellow solution was filtered, then the solvent was removed in vacuo to give a yellow solid comprised primarily of 4 and $\mathrm{FeCp}_{2}$ (55 mg, yield not calculated due to the presence of unidentified impurities).

Reaction of (3) with COT: All solvents, reagents, and glassware were cooled to $-40{ }^{\circ} \mathrm{C}$ for this reaction. A THF solution $(0.4 \mathrm{~mL})$ of cyclooctatetraene $(4.4 \mathrm{mg}, 0.043 \mathrm{mmol})$ was added dropwise to a THF solution ( $1 \mathrm{~mL}$ ) of $\mathbf{3}(50 \mathrm{mg}, 0.043 \mathrm{mmol})$, causing the dark brown solution to turn dark red. The solution was stirred for $15 \mathrm{~min}$, then the solvent was removed in vacuo and the resulting dark red solids were washed with hexane $(2 \mathrm{~mL})$. The product was partially extracted into $\mathrm{Et}_{2} \mathrm{O}$ in $1 \mathrm{~mL}$ aliquots until the extracts were colorless $(4 \mathrm{~mL}$ total), then this solution was filtered, concentrated to $0.7 \mathrm{~mL}$, and stored at $-40{ }^{\circ} \mathrm{C}$. The remainder of the product, poorly soluble in $\mathrm{Et}_{2} \mathrm{O}$, was extracted into $\mathrm{THF}(1 \mathrm{~mL})$, filtered, concentrated to $0.5 \mathrm{~mL}$, 
and stored at $-40{ }^{\circ} \mathrm{C}$. Crystals of the product from $\mathrm{Et}_{2} \mathrm{O}$ were harvested, and ${ }^{1} \mathrm{H}$ NMR spectroscopy revealed these to be mostly 1-crypt (26 mg, 36\% yield). Crystals of the product from THF were harvested and ${ }^{1} \mathrm{H}$ NMR spectroscopy revealed these to be mostly $\mathrm{U}\left(\eta^{8}-\mathrm{C}_{8} \mathrm{H}_{8}\right)_{2}(8$ $\mathrm{mg}, 42 \%$ yield).

\section{B. X-Ray Crystallography}

In a dry nitrogen glovebox, samples of single crystals of 1-8 were coated in Paratone-N oil for transport to diffraction facilities. Crystals were mounted on either a Kaptan loop (for 1, 3, 4, 5, 7, and 8) or on a MiTeGen $10 \mu \mathrm{m}$ aperture Dual-Thickness MicroMount (for 2 and 6). Xray diffraction data for $\mathbf{1}, \mathbf{3}, \mathbf{4}, \mathbf{5}, \mathbf{7}$, and $\mathbf{8}$ was collected at CheXray, Berkeley, CA, using a Rigaku XtaLAB P200 equipped with a MicroMax-007 HF microfocus rotating anode and a Pilatus $200 \mathrm{~K}$ hybrid pixel array detector, using Mo $\mathrm{K} \alpha$ radiation $(\lambda=0.71073 \AA)$. X-ray diffraction data for $\mathbf{2}$ and $\mathbf{6}$ was collected at the Advanced Light Source (ALS), Lawrence Berkeley National Lab, Berkeley, CA, station 12.2.1 using a silicon monochromated beam of 17 $\operatorname{keV}(\lambda=0.7288 \AA)$ synchrotron radiation. All data collections were conducted at $100 \mathrm{~K}$, with the crystals cooled by a stream of dry nitrogen. For $\mathbf{2}$ and $\mathbf{6}$, Bruker APEX3 software was used for the data collections, Bruker SAINT V8.38A software was used to conduct the cell refinement and data reduction procedures, ${ }^{1}$ and absorption corrections were carried out by a multi-scan method utilizing the SADABS program. ${ }^{2}$ For $\mathbf{1}, \mathbf{3}, \mathbf{4}, \mathbf{5}, \mathbf{7}$, and $\mathbf{8}$. CrysAlisPro was used for the data collections and data processing, including a multi-scan absorption correction applied using the SCALE3 ABSPACK scaling algorithm within CrysAlisPro. ${ }^{3}$ Initial structure solutions were found using direct methods (SHELXT), ${ }^{4}$ and refinements were carried out using SHELXL2014. ${ }^{5-7}$ Thermal parameters for all non-hydrogen atoms were refined anisotropically. Thermal ellipsoid plots were made using Mercury. ${ }^{8}$ All structures have been deposited to the Cambridge Crystallographic Data Centre (CCDC), with deposition numbers 2099471-2099478. 
Table S1. Crystallographic details and refinement metrics.

\section{1-crypt}

\begin{tabular}{|c|c|c|c|c|}
\hline Chemical formula & $\begin{array}{l}\mathrm{C}_{86} \mathrm{H}_{140} \mathrm{KN}_{6} \mathrm{O}_{10} \mathrm{U} \\
\cdot\left(\mathrm{C}_{4} \mathrm{H}_{10} \mathrm{O}\right)_{1.5}\end{array}$ & $\mathrm{C}_{51} \mathrm{H}_{78} \mathrm{~N}_{3} \mathrm{O}_{3} \mathrm{U}$ & $\mathrm{C}_{52} \mathrm{H}_{88} \mathrm{KN}_{4} \mathrm{O}_{8} \mathrm{U}$ & $\mathrm{C}_{75} \mathrm{H}_{112} \mathrm{~N}_{4} \mathrm{O}_{4} \mathrm{Th}$ \\
\hline Formula weight & 1806.34 & 1019.19 & 1174.39 & 1365.72 \\
\hline Color, habit & Orange, block & Purple, rod & Brown, block & Colorless, block \\
\hline Crystal system & Triclinic & Triclinic & Triclinic & Triclinic \\
\hline Space group & P-1 & P-1 & P-1 & P-1 \\
\hline$a(\AA)$ & $16.7675(6)$ & $9.8368(3)$ & $13.2153(4)$ & $13.271(1)$ \\
\hline $\mathrm{b}(\AA)$ & $17.1069(6)$ & $13.6132(5)$ & $13.2901(3)$ & $13.596(1)$ \\
\hline c $(\AA)$ & $18.0083(6)$ & $19.8486(7)$ & $17.9214(4)$ & $21.381(2)$ \\
\hline$\alpha\left(^{\circ}\right)$ & $85.773(1)$ & $81.608(1)$ & $103.484(2)$ & $87.500(4)$ \\
\hline$\beta\left(^{\circ}\right)$ & $68.626(1)$ & $77.184(1)$ & $111.495(2)$ & $76.806(4)$ \\
\hline$\gamma\left({ }^{\circ}\right)$ & $88.291(1)$ & $69.039(1)$ & $94.898(2)$ & $85.119(4)$ \\
\hline $\mathrm{V}\left(\AA^{3}\right)$ & 4797.1(3) & $2413.7(2)$ & $2796.72(13)$ & $3741.2(6)$ \\
\hline $\mathrm{Z}$ & 2 & 2 & 2 & 2 \\
\hline Density $\left(\mathrm{g} / \mathrm{cm}^{3}\right)$ & 1.251 & 1.402 & 1.395 & 1.212 \\
\hline$F(000)$ & 1904 & 1042 & 1206 & 1424 \\
\hline Radiation Type & $\begin{array}{l}\operatorname{Mo~K}_{\alpha} \\
(\lambda=0.71073 \AA)\end{array}$ & $\begin{array}{l}\text { Synchrotron } \\
(\lambda=0.7288 \AA)\end{array}$ & $\begin{array}{l}\text { Mo } K_{\alpha} \\
(\lambda=0.71073 \AA)\end{array}$ & $\begin{array}{l}\operatorname{Mo~K}_{\alpha} \\
(\lambda=0.71073 \AA)\end{array}$ \\
\hline$\mu\left(\mathrm{mm}^{-1}\right)$ & 0.883 & 1.589 & 3.028 & 2.039 \\
\hline Crystal size $(\mathrm{mm})$ & $0.08 \times 0.05 \times 0.03$ & $0.12 \times 0.04 \times 0.04$ & $0.24 \times 0.2 \times 0.16$ & $0.34 \times 0.30 \times 0.30$ \\
\hline Meas. Refl. & 70692 & 33125 & 93556 & 91020 \\
\hline Indep. Refl. & 19735 & 9844 & 10231 & 15344 \\
\hline Obsvd. [I $>2 \sigma(\mathrm{I})]$ Refl. & 17671 & 9440 & 9201 & 13755 \\
\hline $\mathrm{R}_{\text {int }}$ & 0.0470 & 0.0277 & 0.1098 & 0.0480 \\
\hline $\begin{array}{l}\text { Final }[I>=2 \sigma(I)] R \\
\text { indices }\end{array}$ & $\begin{array}{l}\mathrm{R}_{1}=0.0291 \\
\mathrm{wR}_{2}=0.0640\end{array}$ & $\begin{array}{l}\mathrm{R}_{1}=0.0157 \\
\mathrm{wR}_{2}=0.0369\end{array}$ & $\begin{array}{l}\mathrm{R}_{1}=0.0401 \\
\mathrm{wR}_{2}=0.1035\end{array}$ & $\begin{array}{l}\mathrm{R}_{1}=0.0303 \\
\mathrm{wR}_{2}=0.0730\end{array}$ \\
\hline Goodness-of-fit & 1.063 & 1.056 & 1.044 & 1.036 \\
\hline $\mathrm{CCDC}$ & 2099473 & 2099476 & 2099475 & 2099477 \\
\hline
\end{tabular}


Table S2. Crystallographic details and refinement metrics.

\begin{tabular}{|c|c|c|c|c|}
\hline & 5 & 6 & 7 & 8 \\
\hline Chemical formula & $\mathrm{C}_{73} \mathrm{H}_{122} \mathrm{KN}_{4} \mathrm{O}_{10} \mathrm{Th}$ & $\begin{array}{l}\mathrm{C}_{86} \mathrm{H}_{140} \mathrm{I}_{3} \mathrm{KNN}_{6} \mathrm{O}_{10} \mathrm{U}_{2} \\
\text { - }\left(\mathrm{C}_{4} \mathrm{H}_{10} \mathrm{O}\right)_{1.5}\end{array}$ & $\mathrm{C}_{63} \mathrm{H}_{103} \mathrm{KN}_{4} \mathrm{O}_{9} \mathrm{U}$ & $\mathrm{C}_{110} \mathrm{H}_{164} \mathrm{~N}_{6} \mathrm{O}_{6} \mathrm{U}_{2}$ \\
\hline Formula weight & 1500.89 & 2423.05 & 1337.62 & 2322.89 \\
\hline Color, habit & Yellow, block & Blue, plate & Red, tablet & Yellow, tablet \\
\hline Crystal system & Triclinic & Triclinic & Triclinic & Monoclinic \\
\hline Space group & P-1 & P-1 & P-1 & $\mathrm{C} 2 / \mathrm{c}$ \\
\hline$a(\AA)$ & $14.6198(3)$ & $15.087(3)$ & $10.9052(4)$ & $33.8622(3)$ \\
\hline $\mathrm{b}(\AA)$ & $15.1940(3)$ & $16.914(3)$ & $15.7349(4)$ & $14.2651(2)$ \\
\hline c $(\AA)$ & $19.0659(2)$ & $21.290(4)$ & $19.2229(6)$ & $49.1634(6)$ \\
\hline$\alpha\left(^{\circ}\right)$ & $108.803(1)$ & $84.50(3)$ & $81.345(2)$ & 90 \\
\hline$\beta\left(^{\circ}\right)$ & $106.483(2)$ & $69.62(3)$ & $81.079(3)$ & $95.999(1)$ \\
\hline$\gamma\left({ }^{\circ}\right)$ & $93.013(2)$ & $82.13(3)$ & $88.996(2)$ & 90 \\
\hline$V\left(\AA^{3}\right)$ & $3795.7(1)$ & $5038(2)$ & $3221.4(2)$ & 23618.2(4) \\
\hline $\mathrm{Z}$ & 2 & 2 & 2 & 8 \\
\hline Density $\left(\mathrm{g} / \mathrm{cm}^{3}\right)$ & 1.313 & 1.597 & 1.379 & 1.307 \\
\hline $\mathrm{F}(000)$ & 1568 & 2400 & 1384 & 9624 \\
\hline Radiation Type & $\begin{array}{l}\operatorname{Mo~K}_{\alpha} \\
(\lambda=0.71073 \AA)\end{array}$ & $\begin{array}{l}\text { Synchrotron } \\
(\lambda=0.7288 \AA)\end{array}$ & $\begin{array}{l}\operatorname{Mo~K}_{\alpha} \\
(\lambda=0.71073 \AA)\end{array}$ & $\begin{array}{l}\operatorname{Mo~K}_{\alpha} \\
(\lambda=0.71073 \AA)\end{array}$ \\
\hline$\mu\left(\mathrm{mm}^{-1}\right)$ & 2.075 & 2.542 & 2.639 & 2.793 \\
\hline Crystal size $(\mathrm{mm})$ & $0.40 \times 0.14 \times 0.09$ & $0.3 \times 0.2 \times 0.05$ & $0.12 \times 0.08 \times 0.04$ & $0.12 \times 0.11 \times 0.07$ \\
\hline Meas. Refl. & 74639 & 18451 & 63612 & 264507 \\
\hline Indep. Refl. & 14398 & 18451 & 12692 & 24094 \\
\hline 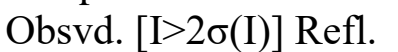 & 12827 & 12693 & 11261 & 20946 \\
\hline $\mathrm{R}_{\text {int }}$ & 0.1290 & 0.1352 & 0.0608 & 0.0695 \\
\hline $\begin{array}{l}\text { Final }[\mathrm{I}>=2 \sigma(\mathrm{I})] \mathrm{R} \\
\text { indices }\end{array}$ & $\begin{array}{l}\mathrm{R}_{1}=0.0509 \\
\mathrm{wR}_{2}=0.1194\end{array}$ & $\begin{array}{l}\mathrm{R}_{1}=0.0618 \\
\mathrm{wR}_{2}=0.1452\end{array}$ & $\begin{array}{l}\mathrm{R}_{1}=0.0301 \\
\mathrm{wR}_{2}=0.0710\end{array}$ & $\begin{array}{l}\mathrm{R}_{1}=0.0253 \\
\mathrm{wR}_{2}=0.0609\end{array}$ \\
\hline Goodness-of-fit & 1.001 & 1.064 & 1.068 & 1.052 \\
\hline $\mathrm{CCDC}$ & 2099474 & 2099471 & 2099472 & 2099478 \\
\hline
\end{tabular}




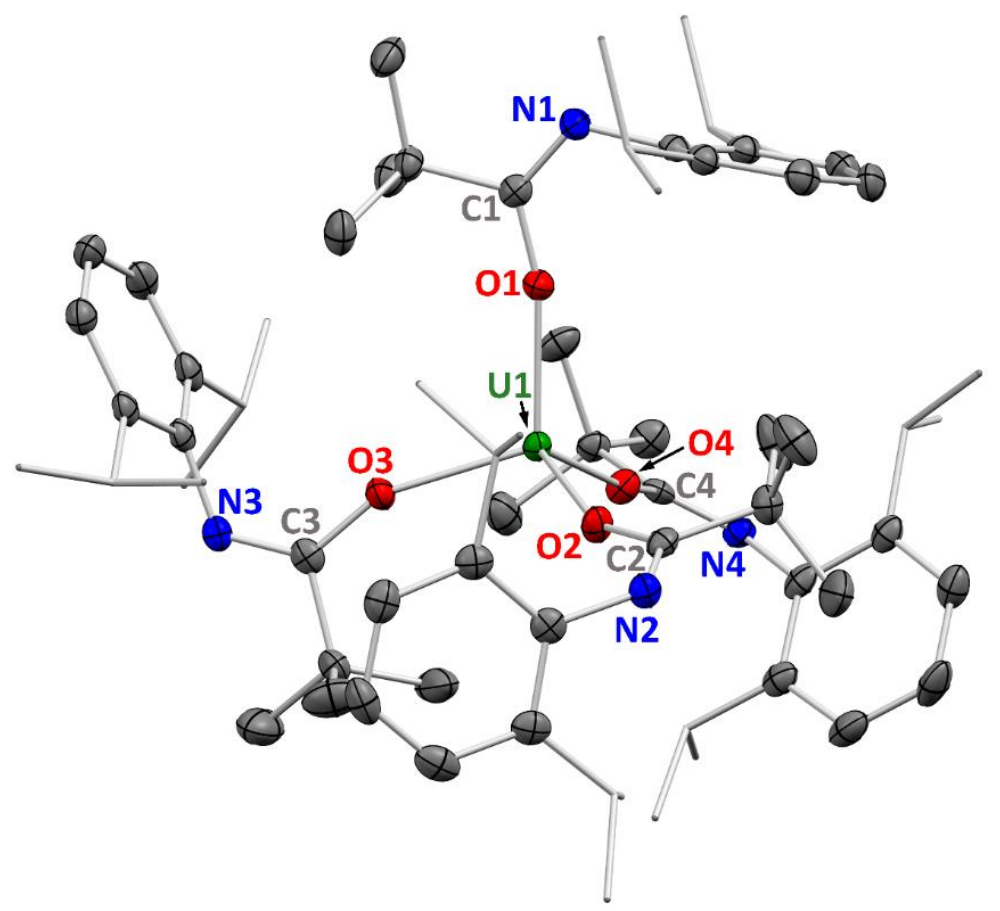

Figure S1. X-ray crystal structure of 1-crypt with 50\% probability ellipsoids. Hydrogen atoms, $\mathrm{K}$ [2.2.2]cryptand, and outer-sphere solvent molecules are omitted, and isopropyl groups are shown as capped sticks for clarity. Selected structural metrics are shown in Table S3.

Table S3. Selected atomic distances $(\AA)$ and angles (deg) for 1-crypt.

\begin{tabular}{cc}
\hline Atoms & 1-crypt \\
\hline $\mathbf{U 1}-\mathbf{O 1}$ & $2.210(2)$ \\
$\mathbf{U 1}-\mathbf{O 2}$ & $2.218(2)$ \\
$\mathbf{U 1}-\mathbf{O 3}$ & $2.247(2)$ \\
$\mathbf{U 1}-\mathbf{O 4}$ & $2.225(2)$ \\
\hline
\end{tabular}




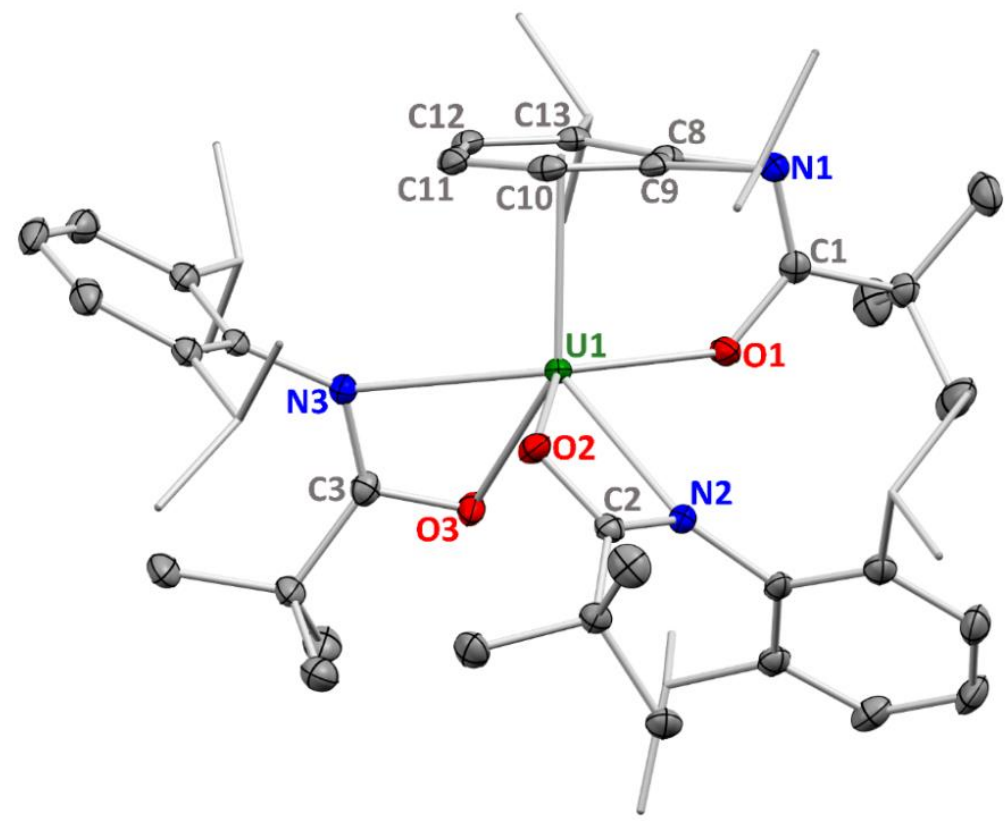

Figure S2. X-ray crystal structure of 2 with 50\% probability ellipsoids. Hydrogen atoms are omitted, and isopropyl groups are shown as capped sticks for clarity. Selected structural metrics are shown in Table S4.

Table S4. Selected atomic distances $(\AA)$ and angles (deg) for 2.

\begin{tabular}{cc}
\hline Atoms & $\mathbf{2}$ \\
\hline U1 - O1 & $2.310(2)$ \\
U1 - O2 & $2.347(2)$ \\
U1 - O3 & $2.334(2)$ \\
U1 - N2 & $2.581(2)$ \\
U1 - N3 & $2.652(2)$ \\
O2 - C2 - N2 & $114.9(2)$ \\
O3 - C3 - N3 & $115.3(2)$ \\
U1 - C8 & $2.899(2)$ \\
U1 - C9 & $2.965(2)$ \\
U1 - C10 & $2.962(2)$ \\
U1 - C11 & $2.939(2)$ \\
U1 - C12 & $2.982(2)$ \\
U1 - C13 & $2.988(2)$ \\
U1 - C (avg, C8-C13) & $2.956(2)$ \\
U1 - Centroid (arene, C8-C13) & $2.602(2)$ \\
C - C (avg) (arene, C8-C13) & $1.404(3)$ \\
\hline
\end{tabular}




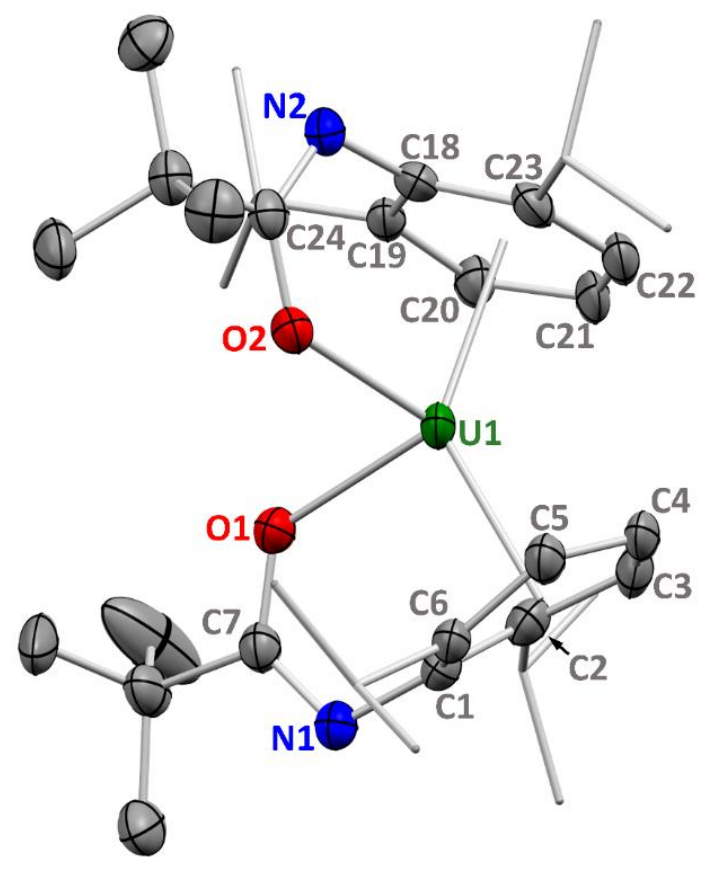

Figure S3. X-ray crystal structure of $\mathbf{3}$ with $50 \%$ probability ellipsoids. Hydrogen atoms and $\mathrm{K}[2.2 .2]$ cryptand are omitted, and isopropyl groups are shown as capped sticks for clarity. Selected structural metrics are shown in Table S5. 
Table S5. Selected atomic distances $(\AA)$ and angles (deg) for 3.

\begin{tabular}{|c|c|}
\hline Atoms & 3 \\
\hline $\mathrm{U} 1-\mathbf{0 1}$ & $2.339(3)$ \\
\hline $\mathrm{U} 1-\mathbf{O} 2$ & $2.356(4)$ \\
\hline $\mathbf{U} 1-\mathbf{N} 1$ & $3.548(4)$ \\
\hline $\mathbf{U} 1-\mathbf{N} 2$ & $3.579(4)$ \\
\hline $\mathbf{O 1}-\mathrm{C} 7-\mathrm{N} 1$ & $123.5(4)$ \\
\hline $\mathrm{O} 2-\mathrm{C} 24-\mathrm{N} 2$ & $124.1(5)$ \\
\hline $\mathbf{U} 1-\mathbf{C} 1$ & $2.689(6)$ \\
\hline $\mathbf{U} 1-\mathbf{C} 2$ & $2.595(6)$ \\
\hline $\mathbf{U} 1-\mathbf{C} 3$ & $2.741(5)$ \\
\hline $\mathrm{U} 1-\mathbf{C} 4$ & $2.714(4)$ \\
\hline $\mathbf{U} 1-\mathbf{C 5}$ & $2.604(5)$ \\
\hline $\mathrm{U} 1-\mathbf{C 6}$ & $2.745(6)$ \\
\hline U1 - C18 & $2.720(6)$ \\
\hline U1 - C19 & $2.728(5)$ \\
\hline $\mathbf{U 1}-\mathbf{C 2 0}$ & $2.706(6)$ \\
\hline U1 - C21 & $2.751(6)$ \\
\hline $\mathbf{U 1}-\mathbf{C 2 2}$ & $2.763(6)$ \\
\hline $\mathbf{U} 1-\mathbf{C} 23$ & $2.716(5)$ \\
\hline U1 - C (avg, C1-C6) & $2.681(6)$ \\
\hline U1 - C (avg, C18-C23) & $2.731(6)$ \\
\hline U1 - Centroid (arene, C1-C6) & $2.274(2)$ \\
\hline U1 - Centroid (arene, C18-C23) & $2.334(2)$ \\
\hline $\mathrm{C}-\mathrm{C}$ (avg) (arene, C1-C6) & $1.427(9)$ \\
\hline $\mathrm{C}-\mathrm{C}$ (avg) (arene, C18-C23) & $1.418(8)$ \\
\hline
\end{tabular}




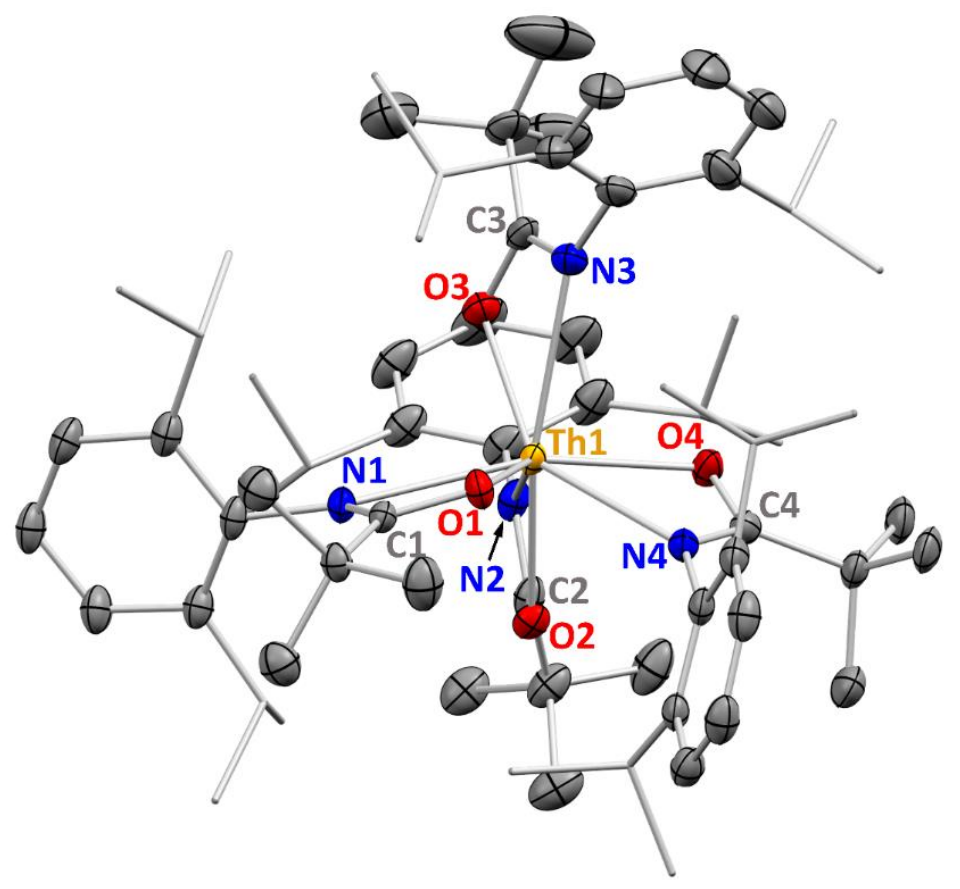

Figure S4. X-ray crystal structure of $\mathbf{4}$ with $50 \%$ probability ellipsoids. Hydrogen atoms are omitted, and isopropyl groups are shown as capped sticks for clarity. Selected structural metrics are shown in Table S6.

Table S6. Selected atomic distances $(\AA)$ and angles (deg) for 4.

\begin{tabular}{|c|c|}
\hline Atoms & 4 \\
\hline Th1 - O1 & $2.348(2)$ \\
\hline Th1 - O2 & $2.353(3)$ \\
\hline Th1 - O3 & $2.343(3)$ \\
\hline Th1 - O4 & $2.366(3)$ \\
\hline Th1 - N1 & $2.724(3)$ \\
\hline Th1 - N2 & $2.599(3)$ \\
\hline Th1 - N3 & $2.716(3)$ \\
\hline Th1 - N4 & $2.595(3)$ \\
\hline $\mathrm{O} 1-\mathrm{C} 1-\mathrm{N} 1$ & 114.7(3) \\
\hline $\mathrm{O} 2-\mathrm{C} 2-\mathrm{N} 2$ & 113.8(3) \\
\hline $\mathrm{O3}-\mathrm{C} 3-\mathrm{N3}$ & 115.1(3) \\
\hline $\mathrm{O} 4-\mathrm{C} 4-\mathrm{N} 4$ & $114.5(3)$ \\
\hline
\end{tabular}




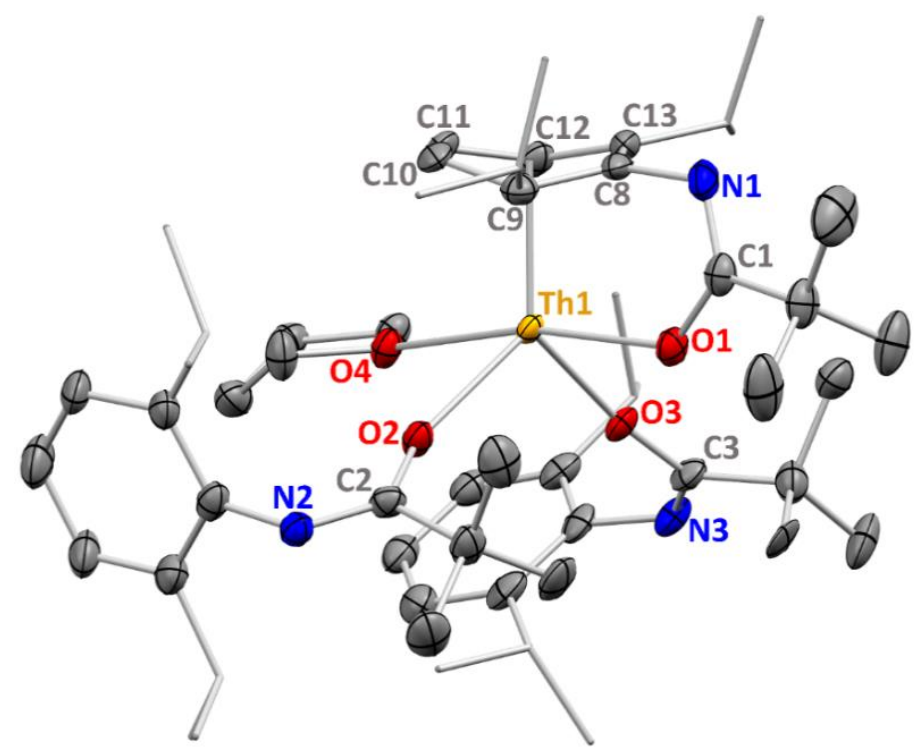

Figure S5. X-ray crystal structure of $\mathbf{5}$ with $50 \%$ probability ellipsoids. Hydrogen atoms and $\mathrm{K}$ [2.2.2] cryptand are omitted, and isopropyl groups are shown as capped sticks for clarity. Selected structural metrics are shown in Table S7.

Table S7. Selected atomic distances $(\AA)$ and angles (deg) for $\mathbf{5}$.

\begin{tabular}{|c|c|}
\hline Atoms & 5 \\
\hline Th1-O1 & $2.400(5)$ \\
\hline Th1 - O2 & $2.332(4)$ \\
\hline Th1 - O3 & $2.316(3)$ \\
\hline Th1 - O4 & $2.586(5)$ \\
\hline Th1 - C8 & $2.674(5)$ \\
\hline Th1 - C9 & $2.549(5)$ \\
\hline Th1 - C10 & $2.783(5)$ \\
\hline Th1 - C11 & $2.742(6)$ \\
\hline Th1 - C12 & $2.556(6)$ \\
\hline Th1 - C13 & $2.794(5)$ \\
\hline $\mathrm{C} 8-\mathrm{C} 9$ & $1.513(9)$ \\
\hline C9- C10 & $1.47(1)$ \\
\hline C10 - C11 & $1.358(9)$ \\
\hline $\mathrm{C} 11-\mathrm{C} 12$ & $1.458(8)$ \\
\hline $\mathrm{C} 12-\mathrm{C} 13$ & $1.47(1)$ \\
\hline $\mathrm{C} 13-\mathrm{C} 8$ & $1.374(9)$ \\
\hline $\mathrm{C} 8-\mathrm{C} 9-\mathrm{C} 10$ & $110.6(5)$ \\
\hline $\mathrm{C} 11-\mathrm{C} 12-\mathrm{C} 13$ & $114.5(5)$ \\
\hline
\end{tabular}




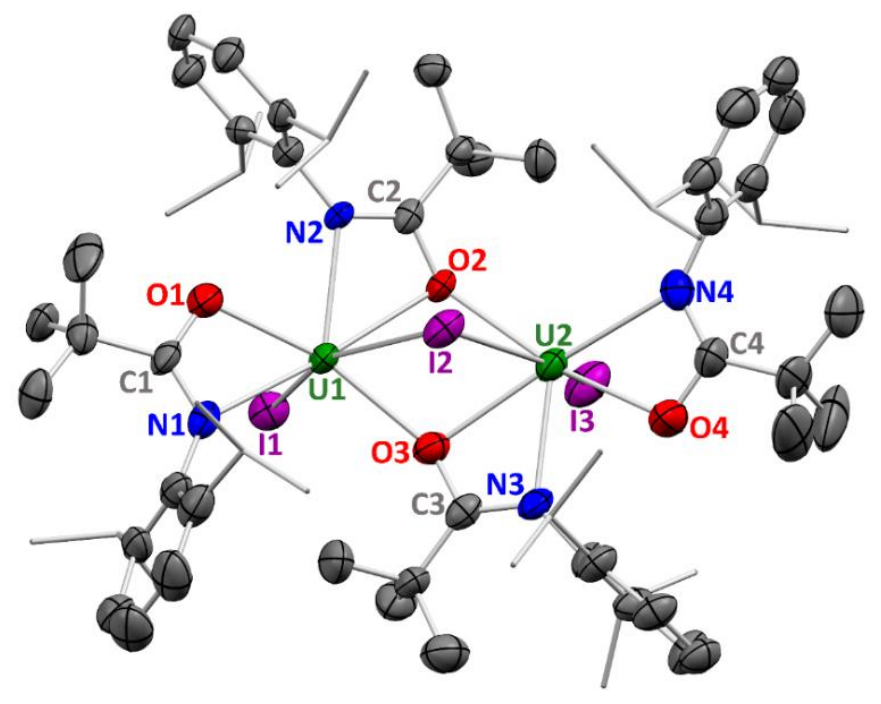

Figure S6. X-ray crystal structure of $\mathbf{6}$ with $50 \%$ probability ellipsoids. Hydrogen atoms, $\mathrm{K}$ [2.2.2]cryptand, and outer-sphere solvent molecules are omitted, and isopropyl groups are shown as capped sticks for clarity. Selected structural metrics are shown in Table S8.

Table S8. Selected atomic distances $(\AA)$ and angles (deg) for $\mathbf{6}$.

\begin{tabular}{cc}
\hline Atoms & $\mathbf{6}$ \\
\hline $\mathbf{U 1}-\mathbf{I 1}$ & $3.068(2)$ \\
$\mathbf{U 1}-\mathbf{I} 2$ & $3.276(2)$ \\
$\mathbf{U} 2-\mathbf{I 2}$ & $3.308(2)$ \\
$\mathbf{U} 2-\mathbf{I 3}$ & $3.081(2)$ \\
$\mathbf{U 1}-\mathbf{O 1}$ & $2.338(7)$ \\
$\mathbf{U 1}-\mathbf{O 2}$ & $2.544(6)$ \\
$\mathbf{U 1}-\mathbf{O 3}$ & $2.440(6)$ \\
$\mathbf{U 1}-\mathbf{N 1}$ & $2.611(8)$ \\
$\mathbf{U 1}-\mathbf{N 2}$ & $2.528(7)$ \\
$\mathbf{O 1}-\mathbf{C 1}-\mathbf{N 1}$ & $114.9(8)$ \\
$\mathbf{O 2}-\mathbf{C 2}-\mathbf{N 2}$ & $114.4(7)$ \\
$\mathbf{U 2}-\mathbf{O 2}$ & $2.462(5)$ \\
$\mathbf{U 2}-\mathbf{O 3}$ & $2.536(6)$ \\
$\mathbf{U 2}-\mathbf{O 4}$ & $2.321(7)$ \\
$\mathbf{U} 2-\mathbf{N 3}$ & $2.514(7)$ \\
$\mathbf{U} 2-\mathbf{N 4}$ & $2.605(7)$ \\
$\mathbf{O 3}-\mathbf{C 3}-\mathbf{N 3}$ & $113.9(7)$ \\
$\mathbf{O 4}-\mathbf{C 4}-\mathbf{N 4}$ & $116.0(8)$ \\
\hline
\end{tabular}




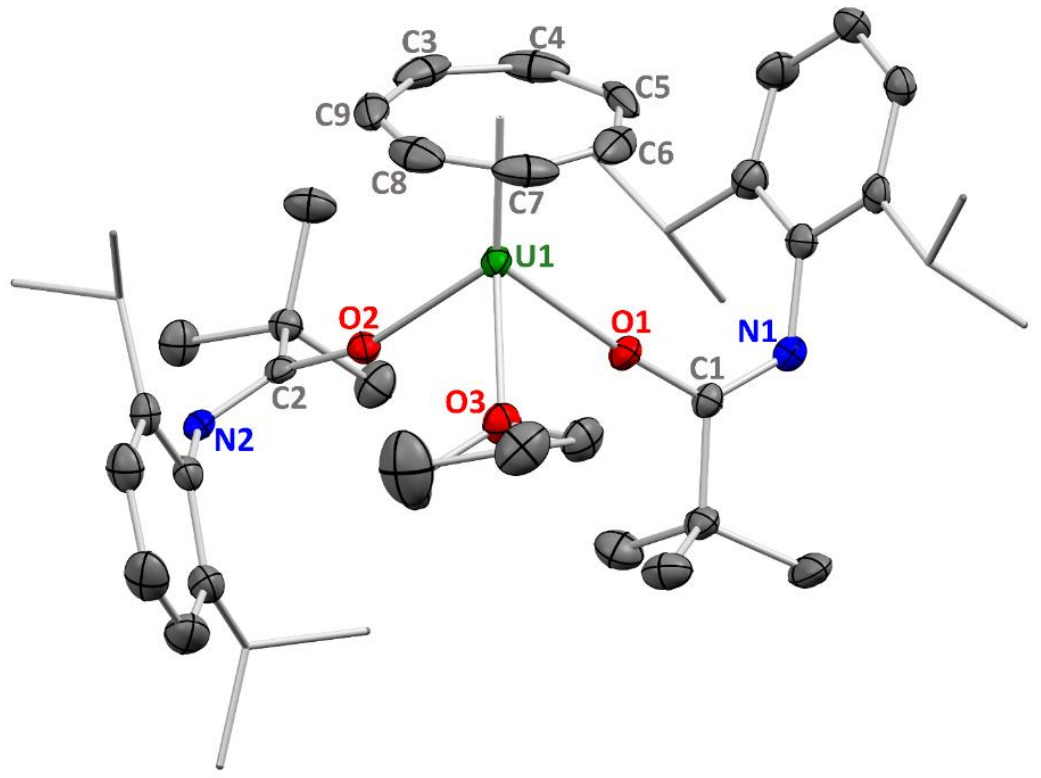

Figure S7. X-ray crystal structure of $\mathbf{7}$ with 50\% probability ellipsoids. Hydrogen atoms and $\mathrm{K}[2.2 .2]$ cryptand are omitted, and isopropyl groups are shown as capped sticks for clarity. Selected structural metrics are shown in Table S9.

Table S9. Selected atomic distances $(\AA)$ and angles (deg) for $\mathbf{7}$.

\begin{tabular}{cc}
\hline Atoms & $\mathbf{7}$ \\
\hline U1 - O1 & $2.255(2)$ \\
U1 - O2 & $2.272(2)$ \\
U1 - O3 & $2.569(2)$ \\
U1 - C3 & $2.571(5)$ \\
U1 - C4 & $2.563(4)$ \\
U1 - C5 & $2.567(4)$ \\
U1 - C6 & $2.577(4)$ \\
U1 - C7 & $2.568(5)$ \\
U1 - C8 & $2.576(4)$ \\
U1 - C9 & $2.572(3)$ \\
U1 - C (avg, C3-C9) & $2.571(5)$ \\
U1 - Centroid (CHT) & $1.991(2)$ \\
C - C (avg) (CHT, C3-C9) & $1.411(7)$ \\
\hline
\end{tabular}




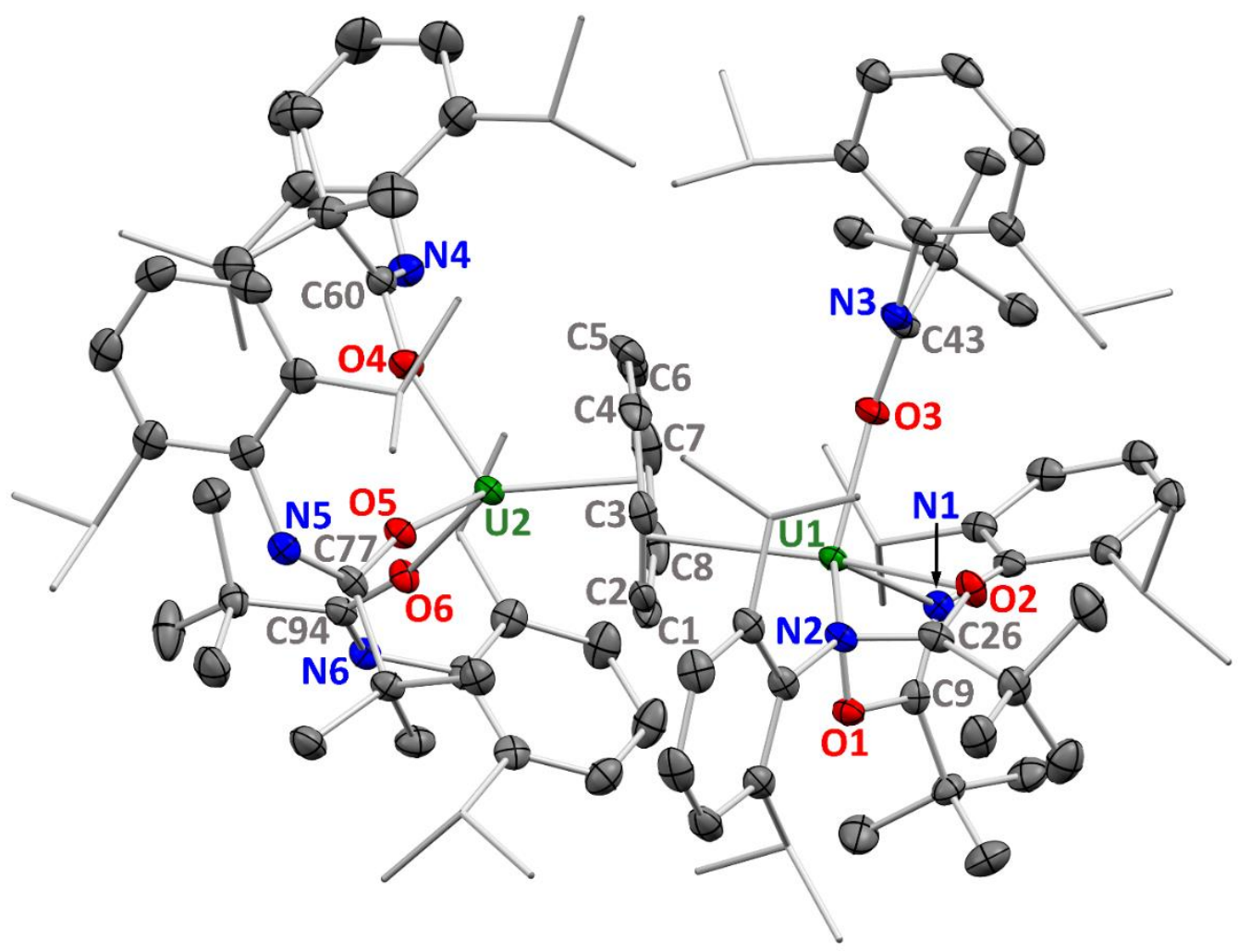

Figure S8. X-ray crystal structure of $\mathbf{8}$ with $50 \%$ probability ellipsoids. Hydrogen atoms and $\mathrm{K}$ [2.2.2]cryptand are omitted, and isopropyl groups are shown as capped sticks for clarity. Selected structural metrics are shown in Table S10. 
Table S10. Selected atomic distances $(\AA)$ and angles (deg) for $\mathbf{8}$.

\begin{tabular}{|c|c|}
\hline Atoms & 8 \\
\hline $\mathrm{U} 1-01$ & $2.268(2)$ \\
\hline $\mathbf{U} 1-\mathbf{O 2}$ & $2.259(2)$ \\
\hline $\mathbf{U 1}-\mathbf{O 3}$ & $2.105(2)$ \\
\hline $\mathbf{U} 1-\mathbf{N} 1$ & $2.480(2)$ \\
\hline $\mathbf{U} 1-\mathbf{N} 2$ & $2.488(2)$ \\
\hline $\mathrm{O} 1-\mathrm{C} 9-\mathrm{N} 1$ & $113.8(2)$ \\
\hline $\mathrm{O} 2-\mathrm{C} 26-\mathrm{N} 2$ & $113.7(2)$ \\
\hline $\mathbf{U 1}-\mathbf{C 1}$ & $2.839(3)$ \\
\hline $\mathrm{U} 1-\mathrm{C} 2$ & $2.708(3)$ \\
\hline $\mathbf{U 1}-\mathbf{C 3}$ & $2.954(3)$ \\
\hline $\mathrm{U} 1-\mathrm{C} 4$ & $3.540(3)$ \\
\hline U1 - C5 & $4.027(3)$ \\
\hline $\mathrm{U} 1-\mathrm{C} 6$ & $4.101(3)$ \\
\hline $\mathbf{U} 1-\mathbf{C 7}$ & $3.762(4)$ \\
\hline $\mathrm{U} 1-\mathrm{C} 8$ & $3.232(4)$ \\
\hline $\mathrm{U} 2-\mathrm{O4}$ & $2.131(2)$ \\
\hline $\mathbf{U} 2-\mathbf{O 5}$ & $2.171(2)$ \\
\hline U2 - O6 & $2.148(2)$ \\
\hline $\mathbf{U} 2-\mathbf{C} 1$ & $2.759(3)$ \\
\hline $\mathbf{U} 2-\mathbf{C} 2$ & $2.760(3)$ \\
\hline $\mathbf{U} 2-\mathbf{C} 3$ & $2.824(3)$ \\
\hline $\mathrm{U} 2-\mathrm{C} 4$ & $2.810(3)$ \\
\hline $\mathrm{U} 2-\mathbf{C 5}$ & $2.753(3)$ \\
\hline $\mathrm{U} 2-\mathrm{C} 6$ & $2.744(3)$ \\
\hline $\mathbf{U} 2-\mathbf{C} 7$ & $2.789(3)$ \\
\hline $\mathrm{U} 2-\mathrm{C} 8$ & $2.816(3)$ \\
\hline $\mathrm{U} 2-\mathrm{C}(\operatorname{avg}, \mathrm{C} 1-\mathrm{C} 8)$ & $2.782(3)$ \\
\hline U2 - Centroid (COT) & $2.094(2)$ \\
\hline $\mathrm{C}-\mathrm{C}(\mathrm{avg})(\mathrm{COT}, \mathrm{C} 1-\mathrm{C} 8)$ & $1.403(5)$ \\
\hline
\end{tabular}




\section{EPR Spectroscopy}

EPR spectroscopy was performed in the CalEPR center in the Department of Chemistry, University of California at Davis. X-band continuous wave (CW) EPR spectroscopy was carried out on the Bruker Biospin EleXsys E500 spectrometer with a super high Q resonator (ER4122SHQE) in perpendicular mode and dual mode cavity (ER4116DM) in both perpendicular and parallel modes. All CW-EPR spectra were recorded on solid samples under slow-passage, non-saturating conditions. Spectrometer settings were: conversion time, $40 \mathrm{~ms}$; modulation amplitude, $0.5-0.8 \mathrm{mT}$; modulation frequency, $100 \mathrm{kHz}$; and other settings as indicated in figure captions. High-field, high-frequency EPR spectrum was measured at a temperature of $4.5 \mathrm{~K}$ using a home-built $130 \mathrm{GHz}$ EPR spectrometer equipped with an OxfordCF935 liquid helium cryostat as described previously. ${ }^{5}$ Magnetic field-swept echo-detected EPR spectrum was acquired using the Hahn echo pulse sequence: $\pi / 2-\tau-\pi-$ echo, with a $\pi / 2$ pulse duration of $40 \mathrm{~ns}, \tau$ of $250 \mathrm{~ns}, \pi$ pulse of $80 \mathrm{~ns}$. Simulations of the EPR data were performed using EasySpin toolbox ${ }^{6}$ in Matlab software.

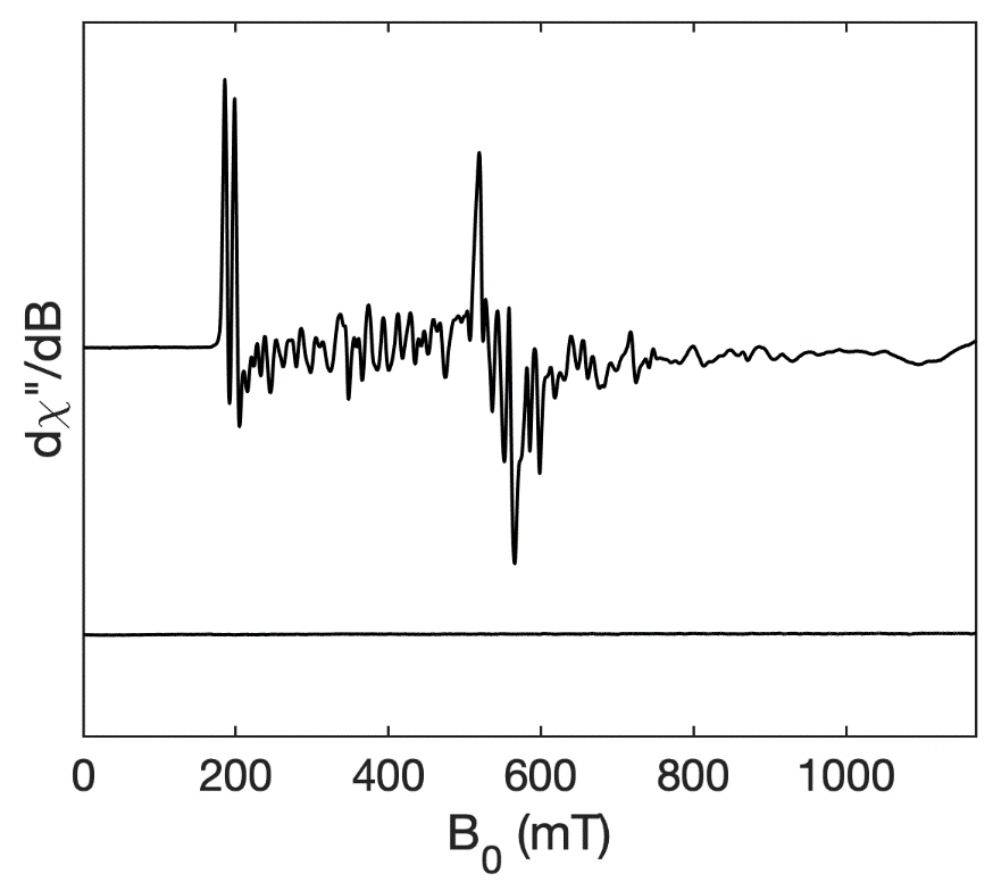

Figure S9. (Top) X-band (9.7 GHz) CW-EPR in perpendicular mode of 2. (Bottom) X-band (9.4 GHz) $\mathrm{CW}$-EPR in parallel mode of $\mathbf{2}$. Conditions: temperature, $5 \mathrm{~K}$; microwave power, $0.2 \mathrm{~mW}$; modulation amplitude $0.8 \mathrm{mT}$. 


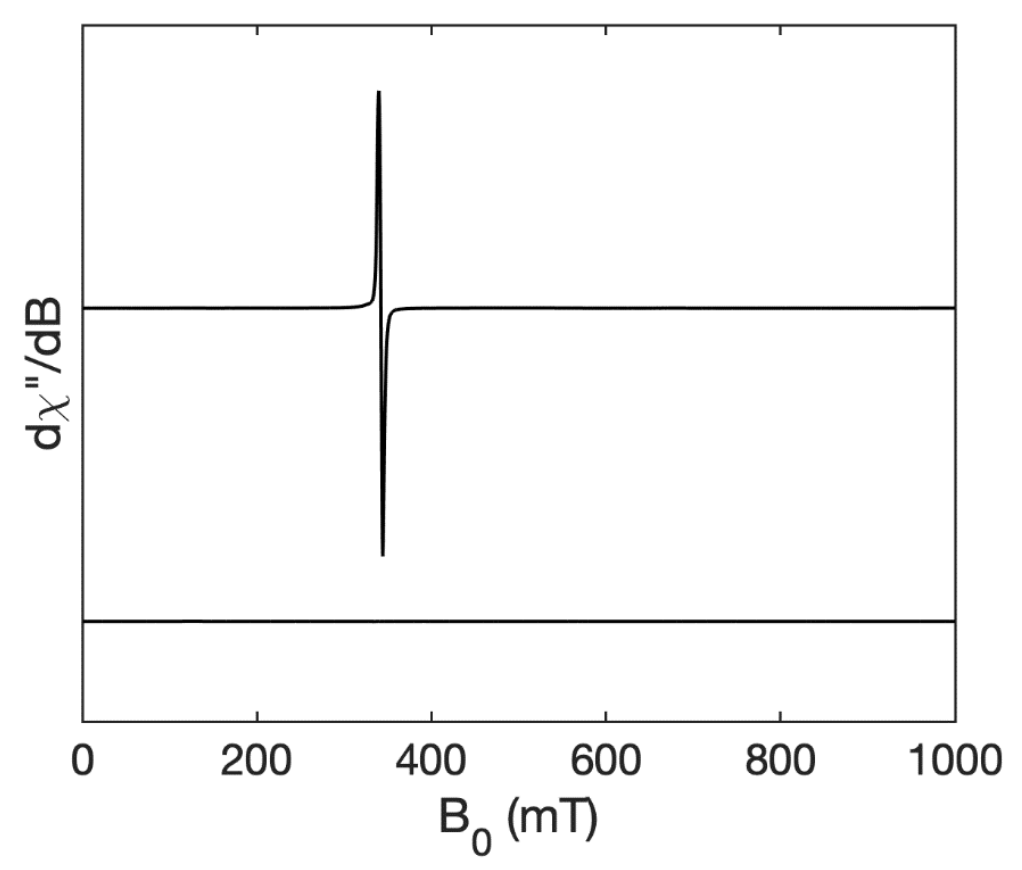

Figure S10. (Top) X-band (9.7 GHz) CW-EPR in perpendicular mode of 3. (Bottom) Xband $(9.4 \mathrm{GHz}) \mathrm{CW}$-EPR in parallel mode of 3 . Conditions: temperature, $5 \mathrm{~K}$; microwave power, $0.2 \mathrm{~mW}$; modulation amplitude, $0.5 \mathrm{mT}$.

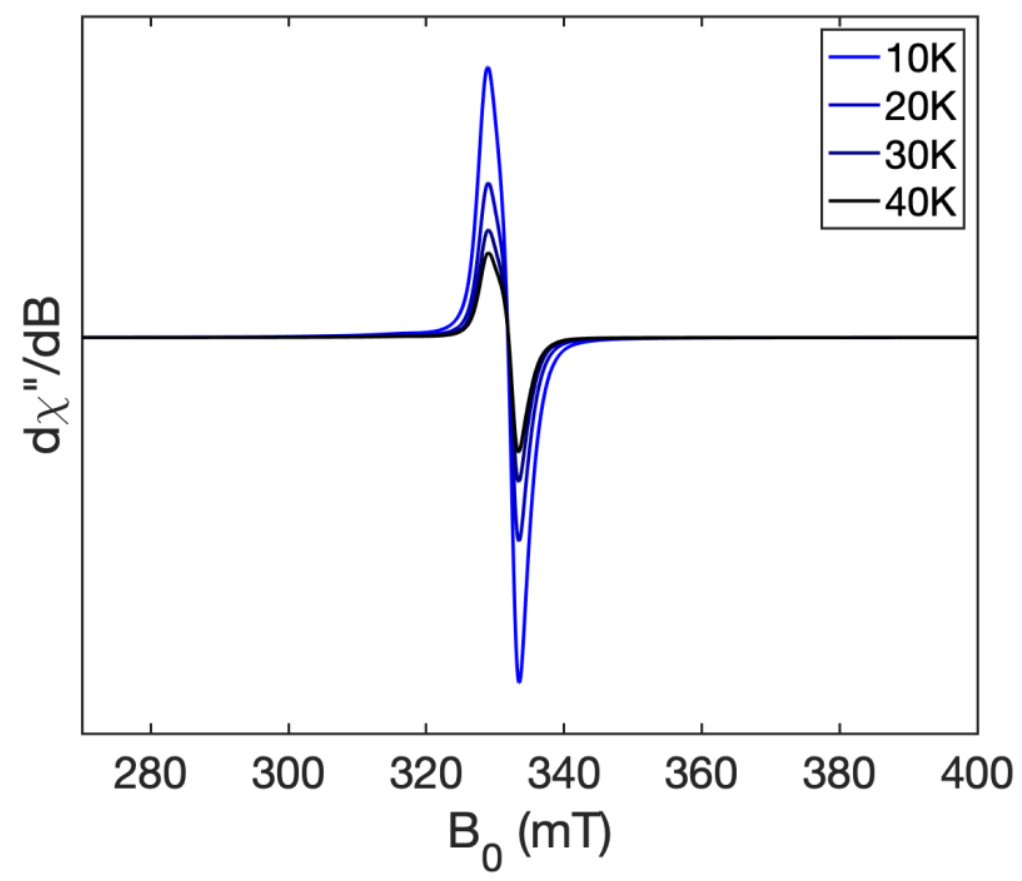

Figure S11. X-band $(9.4 \mathrm{GHz}) \mathrm{CW}$-EPR in perpendicular mode of 3 . Conditions: temperature, $10 \mathrm{~K}, 20 \mathrm{~K}, 30 \mathrm{~K}, 40 \mathrm{~K}$; microwave power, $0.2 \mathrm{~mW}$; modulation amplitude, 0.5 $\mathrm{mT}$. 


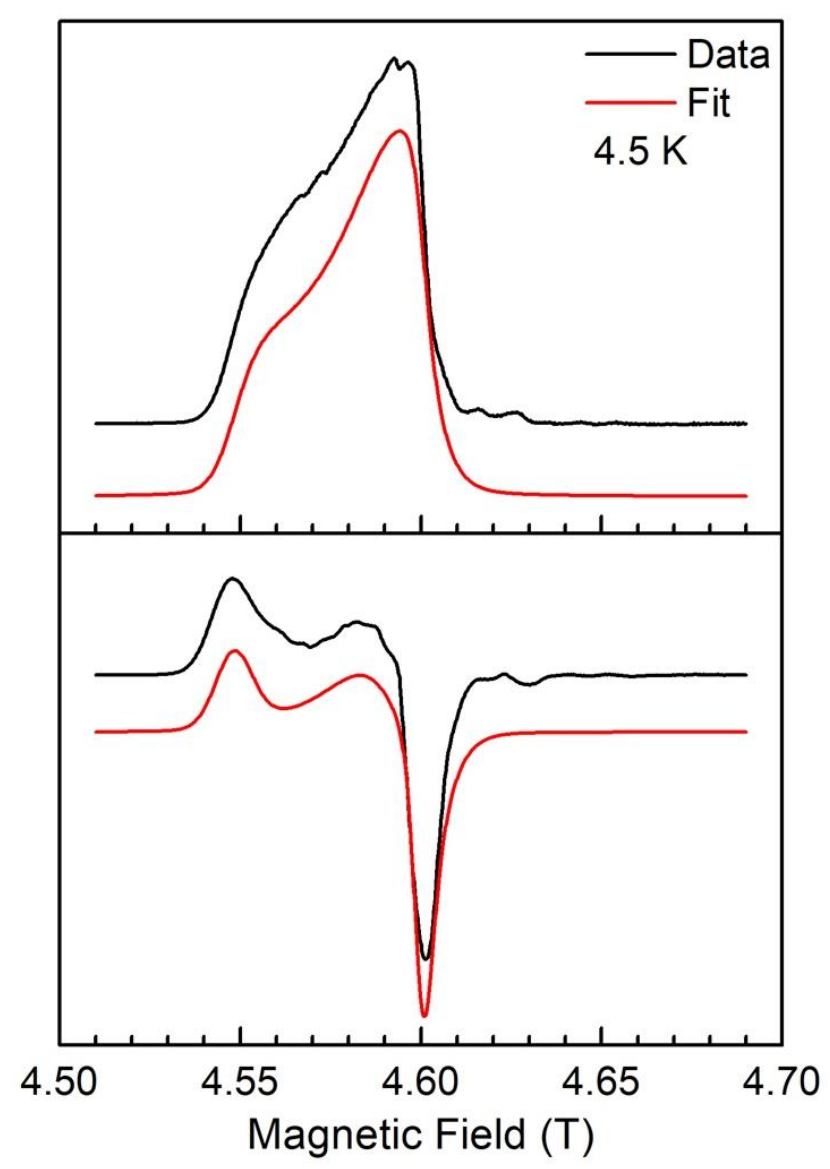

Figure S12. (Top) Field-swept echo-detected EPR spectrum of 3 measured at $130 \mathrm{GHz}, 4.5 \mathrm{~K}$ (black line). Red line depicts simulation using $S=\frac{1}{1} 2, g=\left[\begin{array}{ll}2.042 & 2.022 \\ 2.019\end{array}\right], g$ Strain $=[0.005$ 0.010 0.002]. (Bottom) Derivative-like spectrum generated from pseudo-modulation of the echodetected spectrum (black line) and its corresponding simulation (red line). Pseudo-modulation amplitude, $1 \mathrm{mT}$. 


\section{Magnetic Measurements}

Samples for magnetic measurements were prepared in a nitrogen-atmosphere glovebox by adding polycrystalline powder ( $34.3 \mathrm{mg}$ for 2 and $16.9 \mathrm{mg}$ for 3 ) to a quartz tube (5 mm inner diameter, $7 \mathrm{~mm}$ outer diameter). A layer of glass wool was added on top of each sample to prevent crystallite torquing. The tubes were fitted with Teflon sealable adapters, evacuated using a glovebox pump, and flame sealed with an $\mathrm{O}_{2} / \mathrm{H}_{2}$ torch under vacuum. Dc magnetic susceptibility measurements were performed under applied fields of 1, 10, and $70 \mathrm{kOe}$. All magnetic susceptibility data were corrected for diamagnetic contributions from the core diamagnetism of the sample, estimated using Pascal's constants to give corrections of $\chi_{\text {dia }}=-$ 0.000590 for $\mathbf{3}$ and -0.000674 for $\mathbf{3}$.
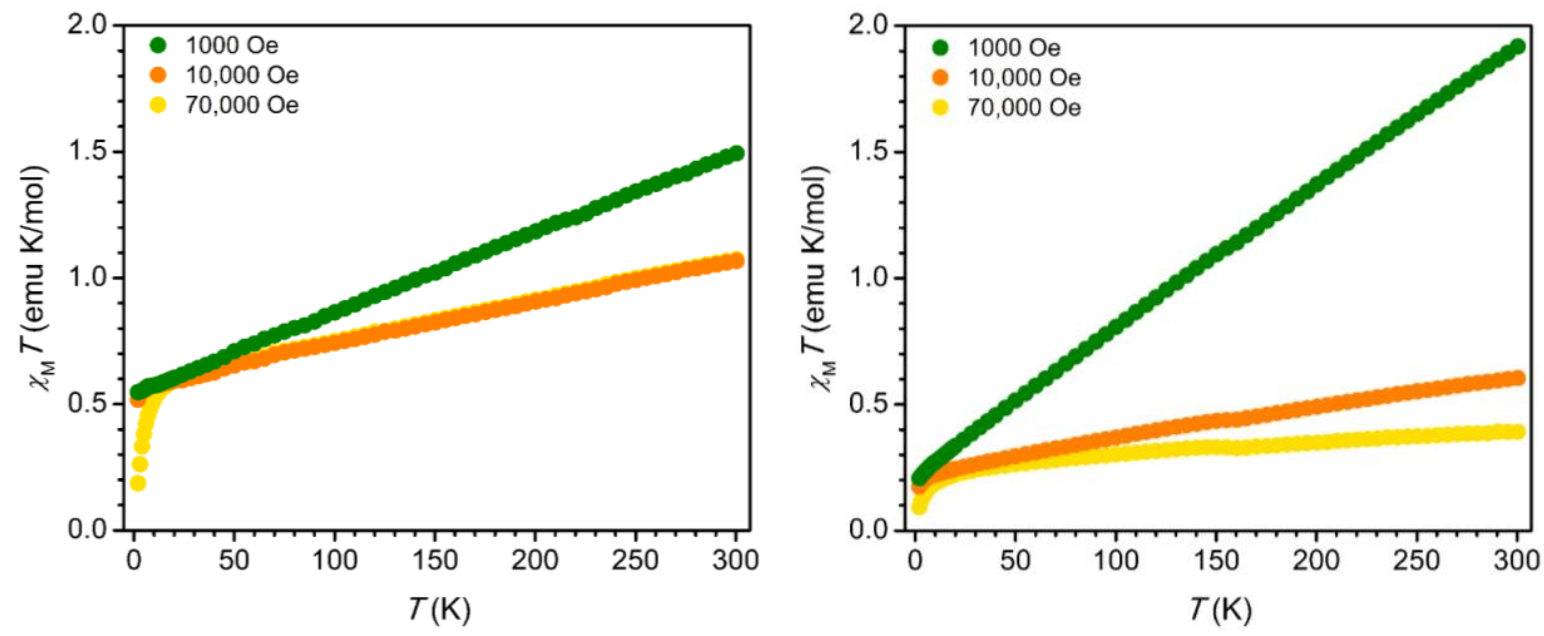

Figure S13. (Left) Zero-field-cooled dc magnetic susceptibility data for U(TDA) 3 (2, left) and [K[2.2.2]cryptand][U(TDA $\left.)_{2}\right]$ (3, right) under applied fields of 1, 10, and $70 \mathrm{kOe}$. 


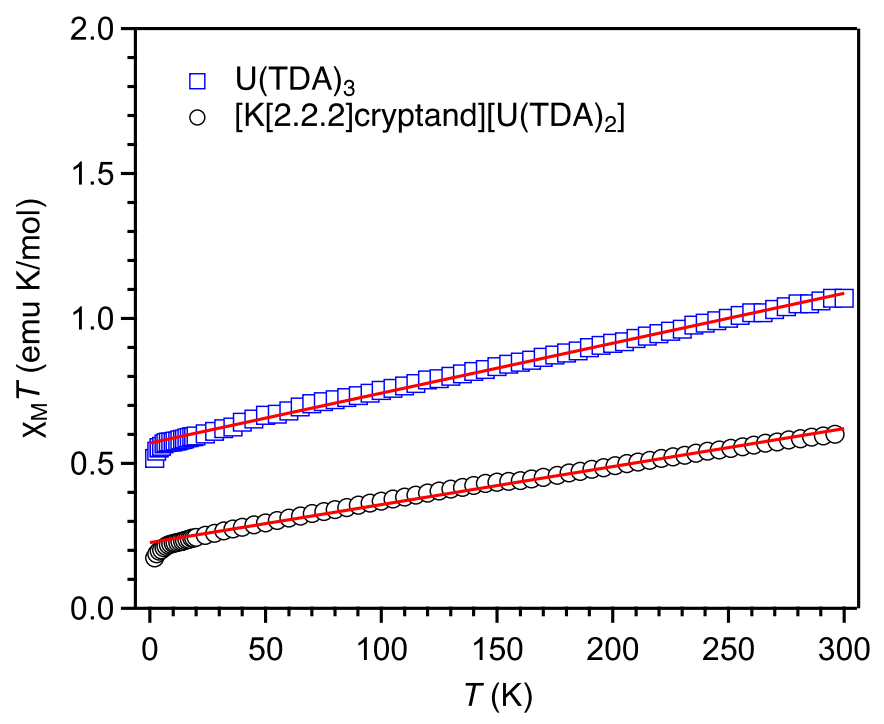

Figure S14. Comparison between variable-temperature molar magnetic data for U(TDA) 3 (2, blue squares) and [U(TDA) $\left.)_{2}\right][\mathrm{K}[2.2 .2]$ cryptand $](3$, black circles) at $10 \mathrm{kOe}$, and linear fits to the data from $10 \mathrm{~K}$ to $300 \mathrm{~K}$ (red traces).

\section{E. UV-vis-NIR Spectra}

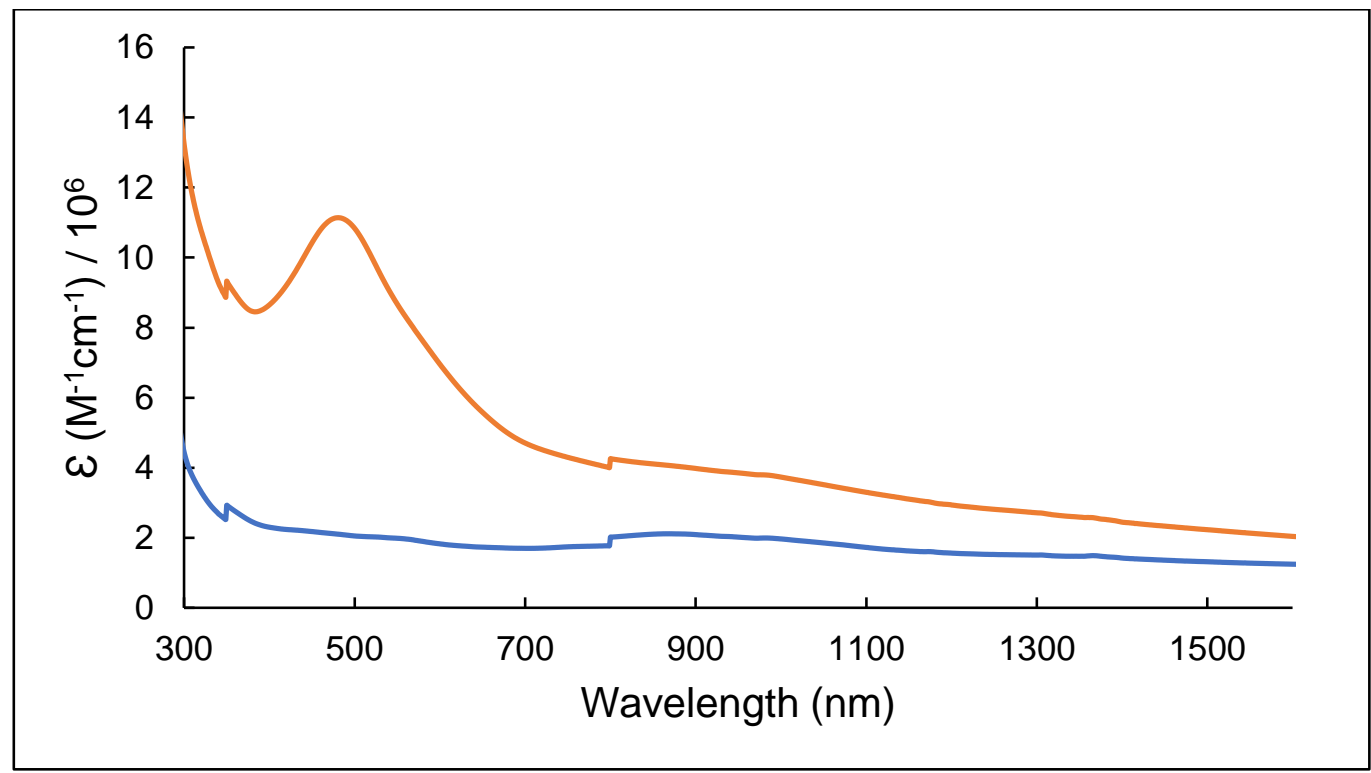

Figure S15. UV-vis-NIR spectra of U(TDA) 3 (2) and [K[2.2.2]cryptand][U(TDA) $)_{2}$ (3) collected from $0.1 \mathrm{mg} / \mathrm{mL}$ solutions of 2 and 3 in THF. The sharp features at ca. 400 and $800 \mathrm{~nm}$ are artifacts caused by a grating switch at these wavelengths. 


\section{F. NMR Spectra}

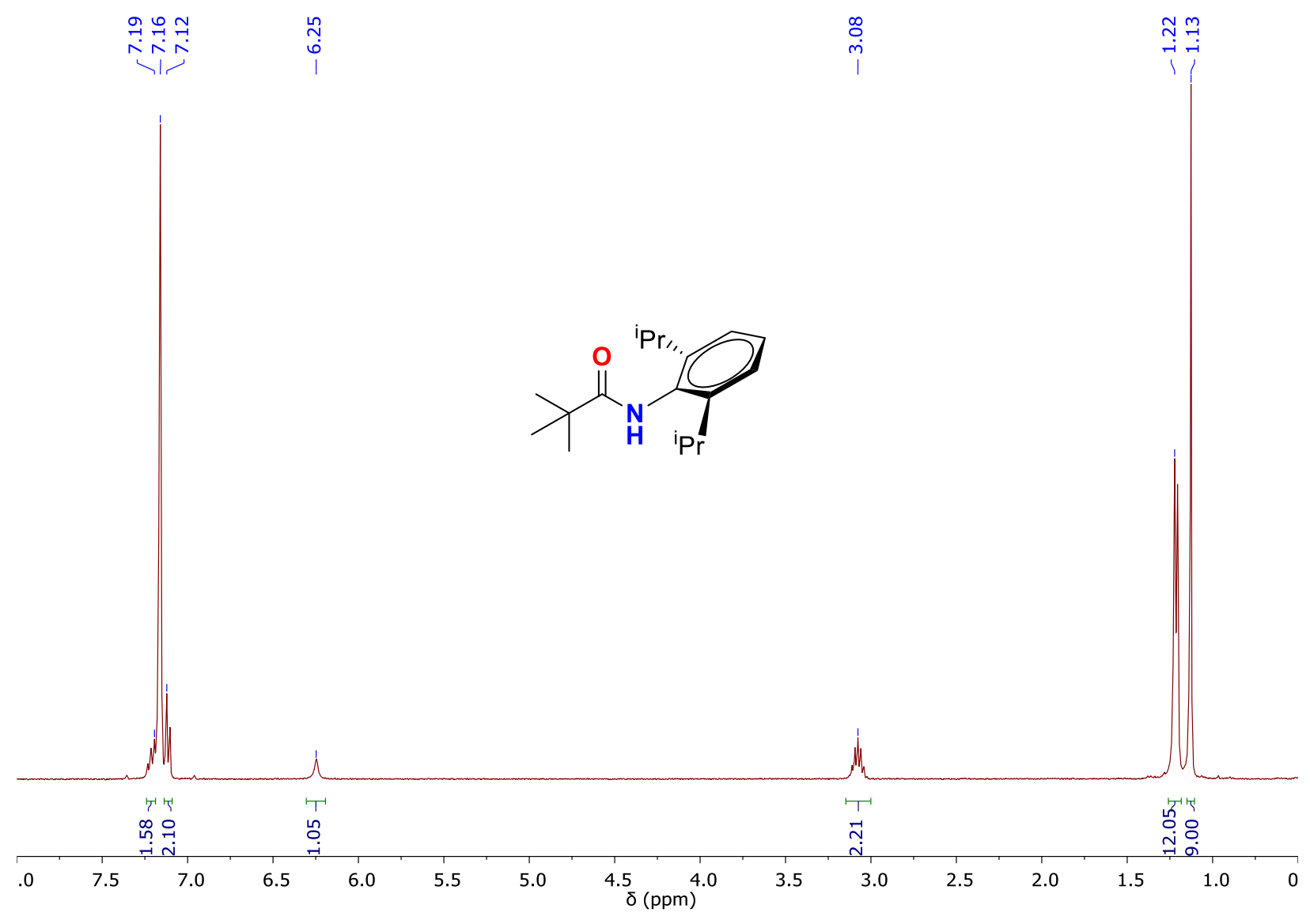

Figure S16. ${ }^{1} \mathrm{H}$ NMR spectrum of $\mathrm{H}(\mathrm{TDA})$ in $\mathrm{C}_{6} \mathrm{D}_{6}$. 


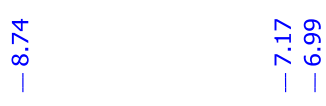

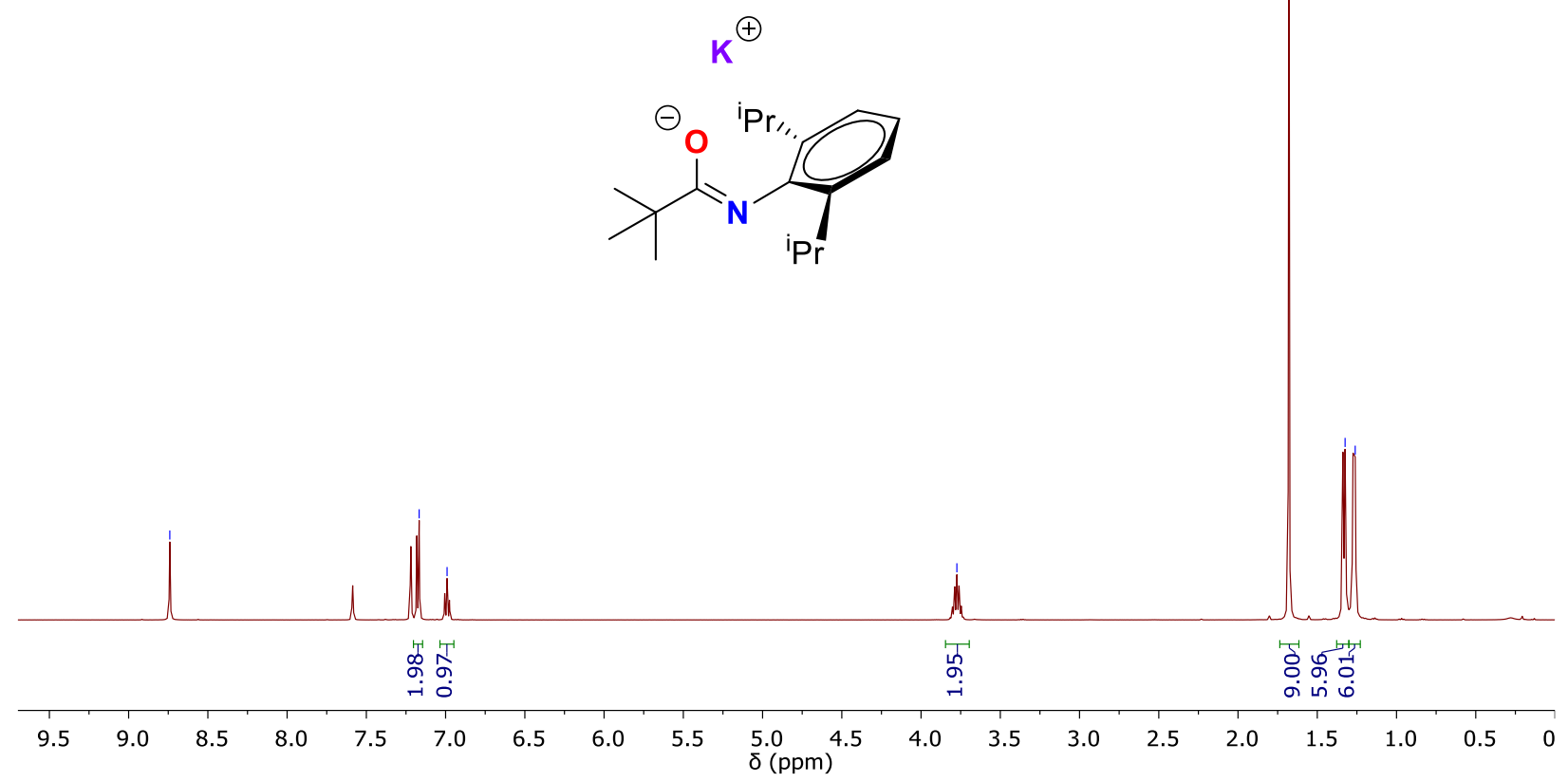

$\underset{\substack{n \\ m}}{i}$

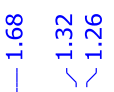

Figure S17. ${ }^{1} \mathrm{H}$ NMR spectrum of $\mathrm{K}(\mathrm{TDA})$ in $\mathrm{C}_{5} \mathrm{D}_{5} \mathrm{~N}$. 

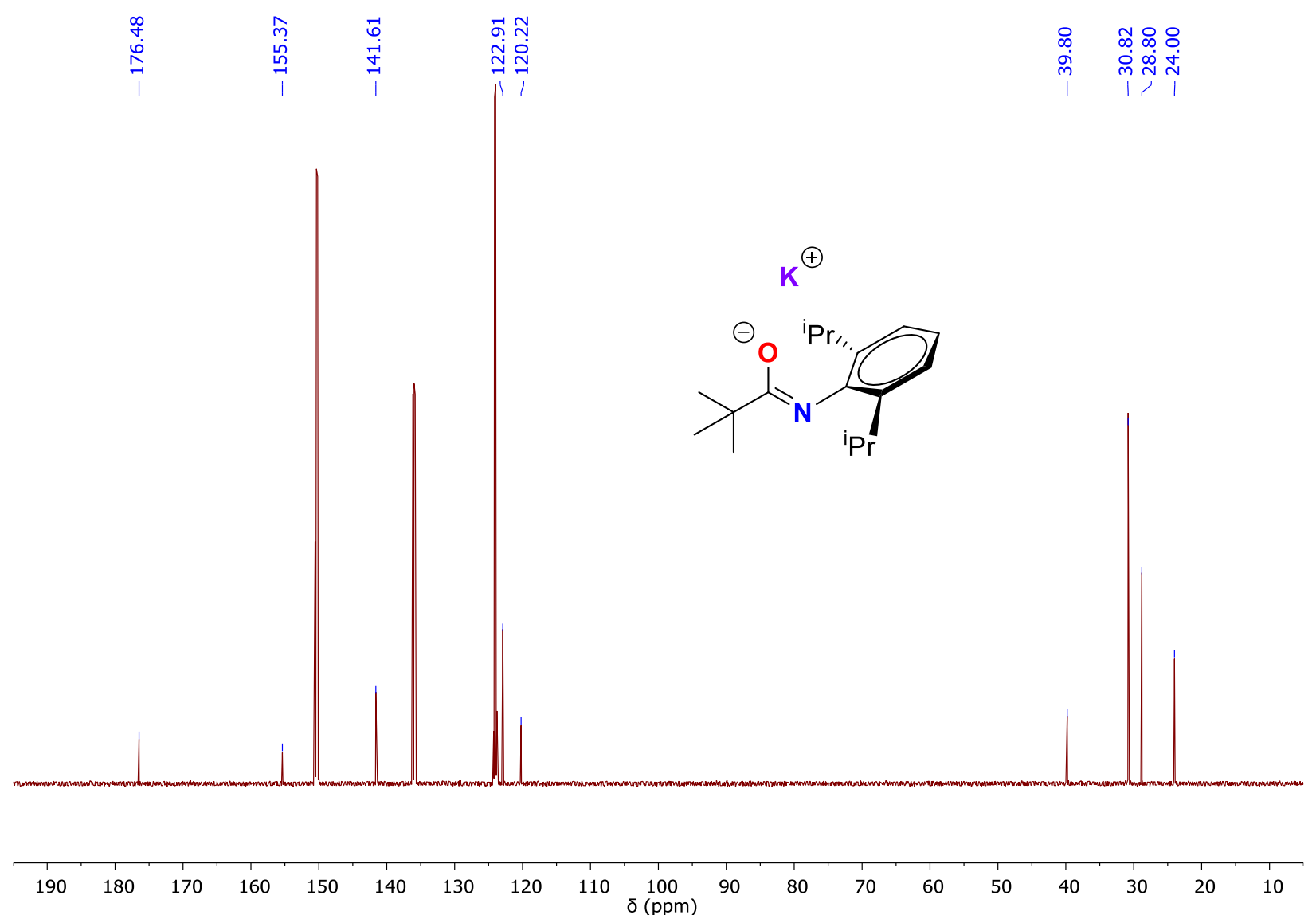

Figure S18. ${ }^{13} \mathrm{C}$ NMR spectrum of $\mathrm{K}(\mathrm{TDA})$ in $\mathrm{C}_{5} \mathrm{D}_{5} \mathrm{~N}$. 


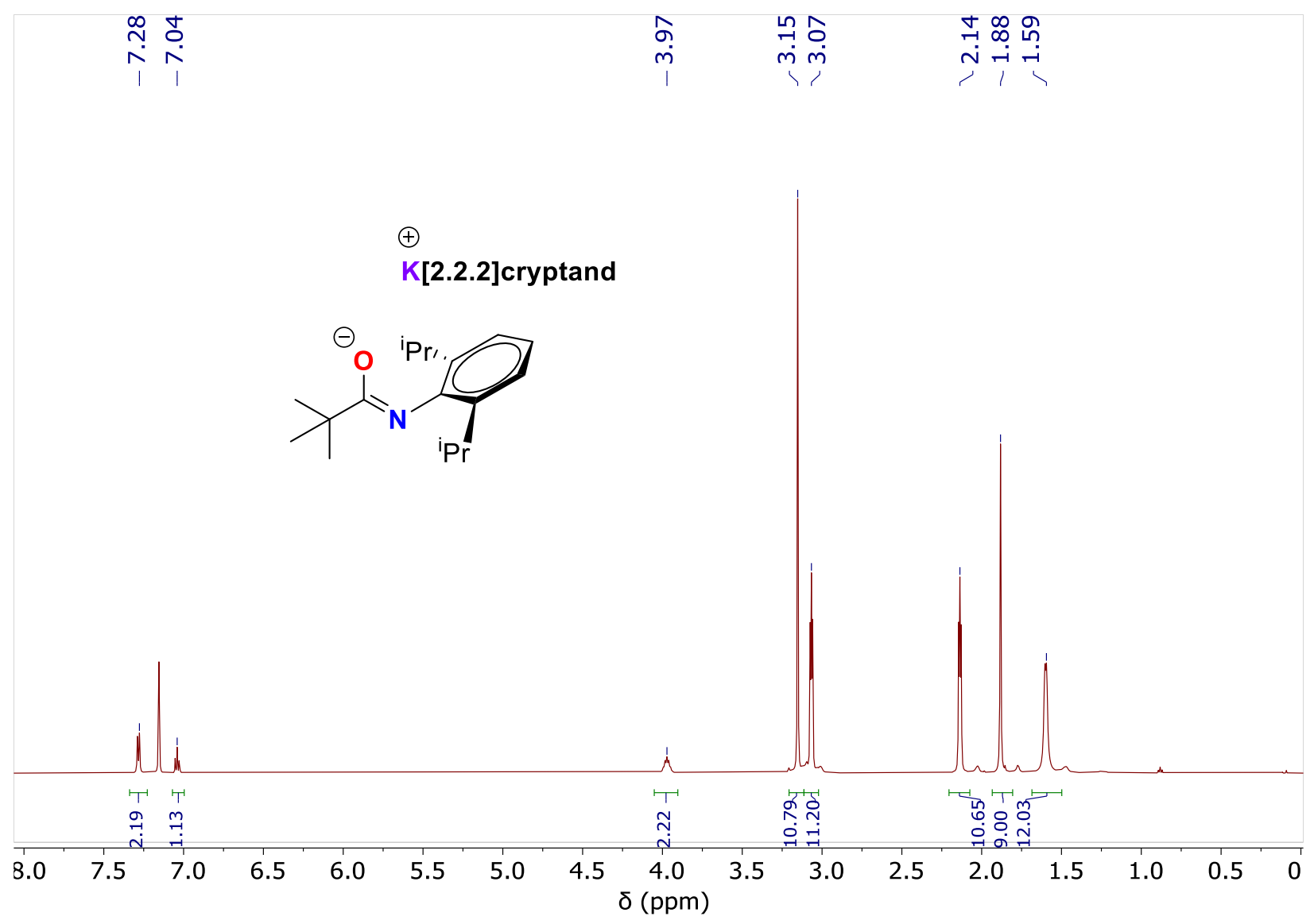

Figure S19. ${ }^{1} \mathrm{H}$ NMR spectrum of K(TDA)[2.2.2] cryptand in $\mathrm{C}_{6} \mathrm{D}_{6}$. 


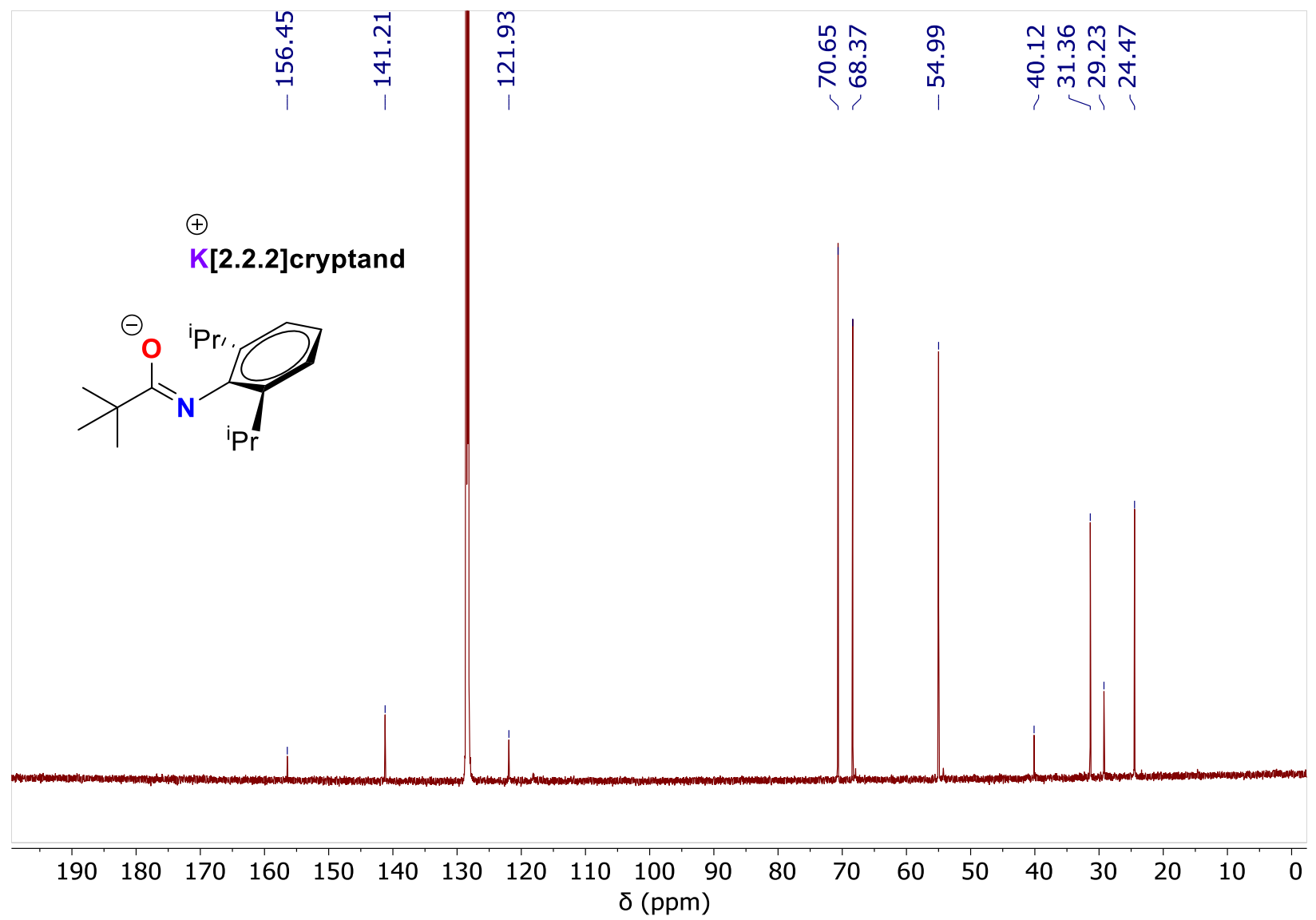

Figure S20. ${ }^{13} \mathrm{C}$ NMR spectrum of $\mathrm{K}(\mathrm{TDA})[2.2 .2]$ cryptand in $\mathrm{C}_{6} \mathrm{D}_{6}$. 


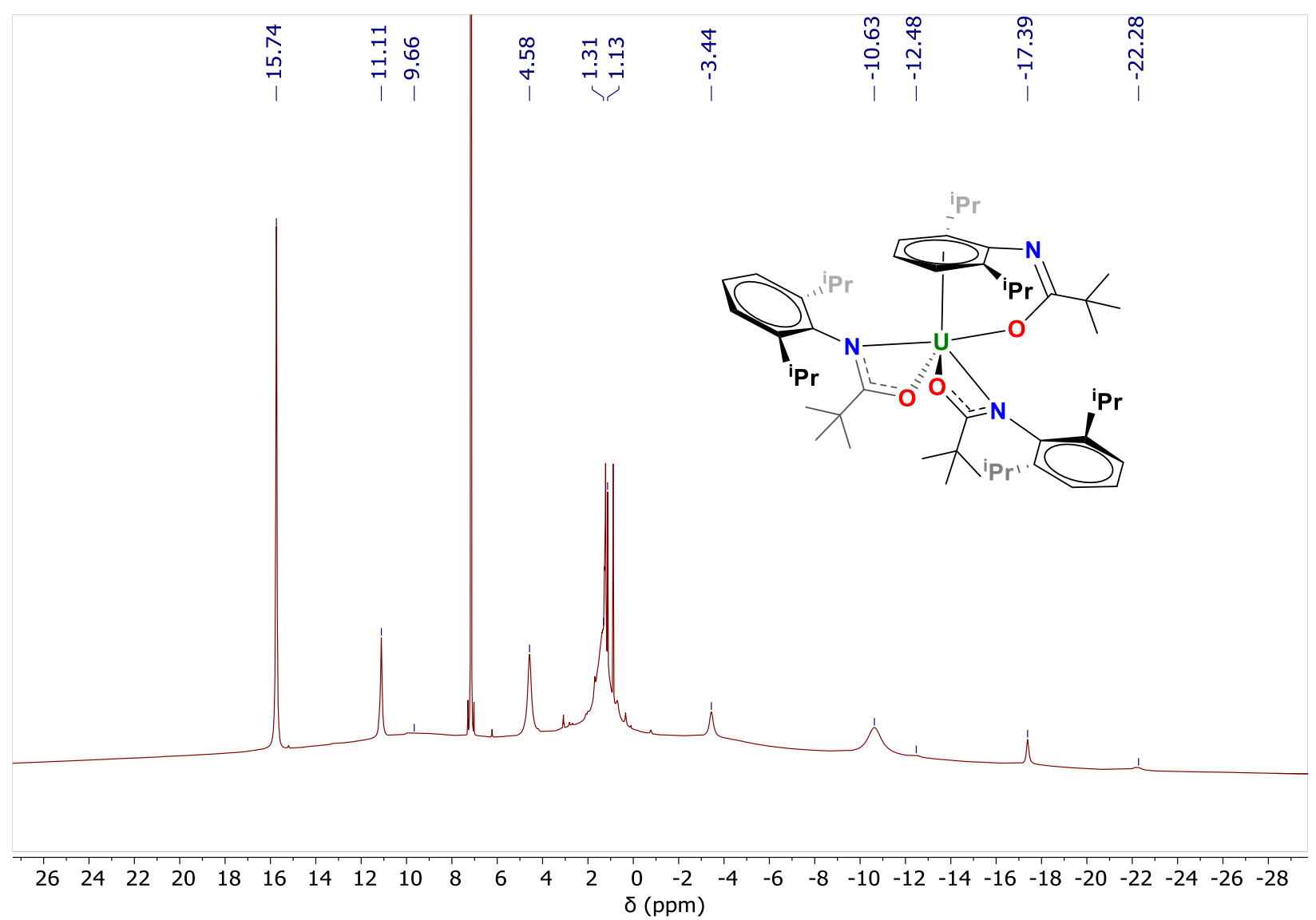

Figure S21. ${ }^{1} \mathrm{H}$ NMR spectrum of $\mathrm{U}(\mathrm{TDA})_{3}(2)$ in $\mathrm{C}_{6} \mathrm{D}_{6}$. The sharp peaks at 0.89 and $1.23 \mathrm{ppm}$ are from residual hexane. 


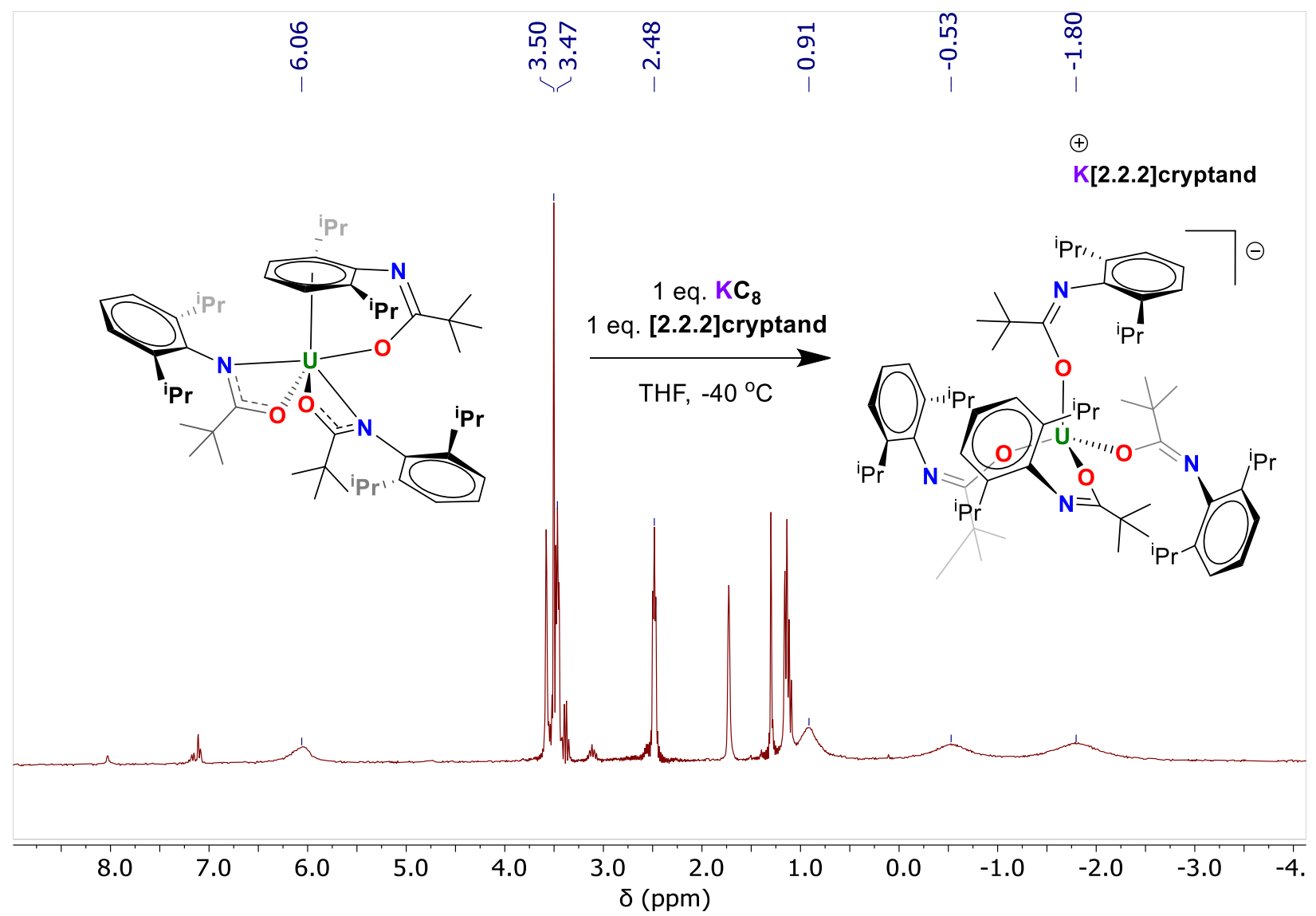

Figure S22. ${ }^{1} \mathrm{H}$ NMR spectrum in $\mathrm{d}_{8}$-THF of [K[2.2.2]cryptand][U(TDA) $)_{4}$ (1-crypt) formed by reacting $\mathrm{U}(\mathrm{TDA})_{3}(\mathbf{2})$ with one equivalent each of $\mathrm{KC}_{8}$ and [2.2.2]cryptand. 


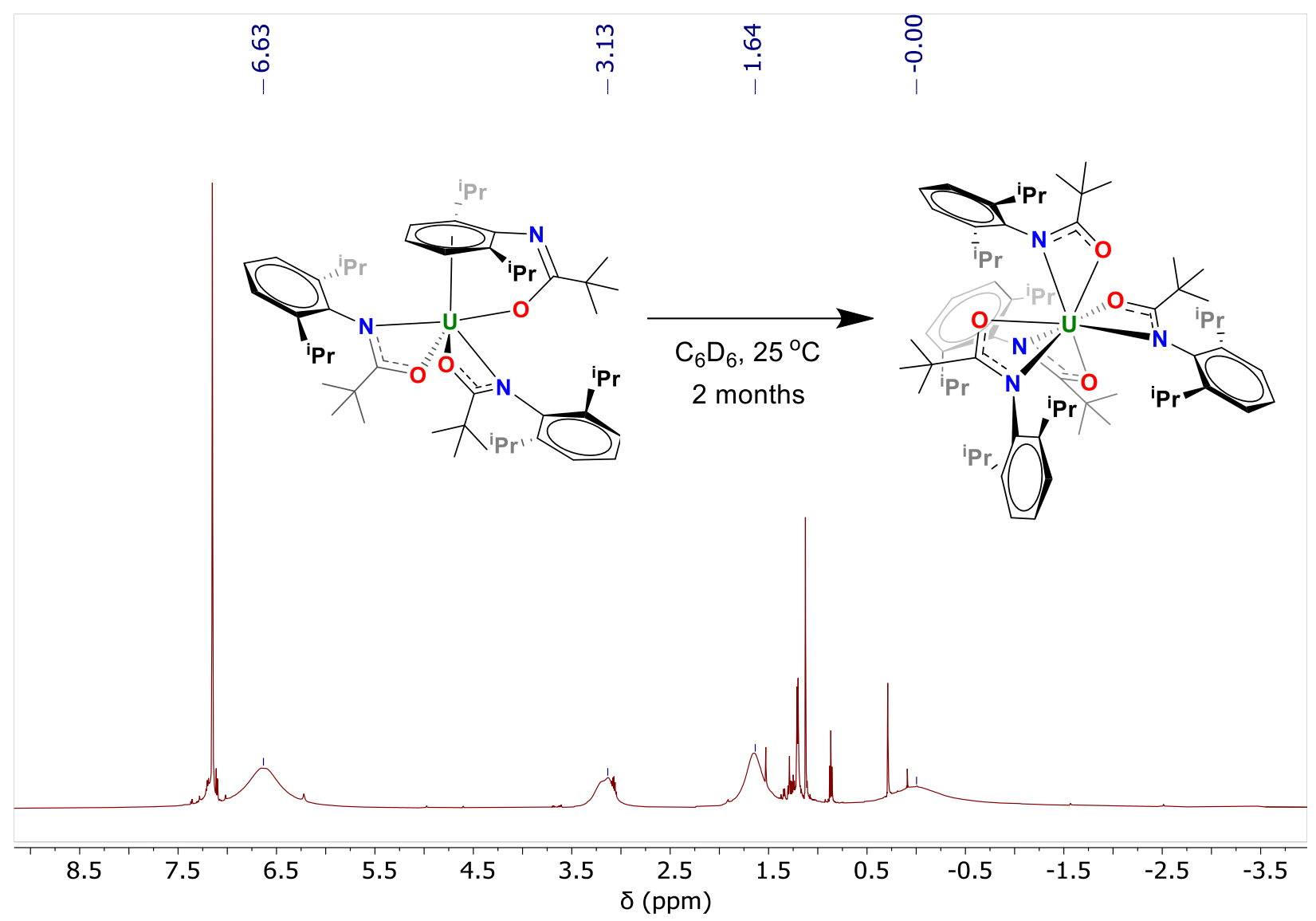

Figure S23. ${ }^{1} \mathrm{H}$ NMR spectrum of the products formed by leaving a $\mathrm{C}_{6} \mathrm{D}_{6}$ solution of U(TDA) $)_{3}$ (2) undisturbed at room temperature for 2 months. U(TDA) $)_{4}$ is clearly visible as the major product, with broad peaks at $6.63,3.13,1.64$, and $0.00 \mathrm{ppm}$. 


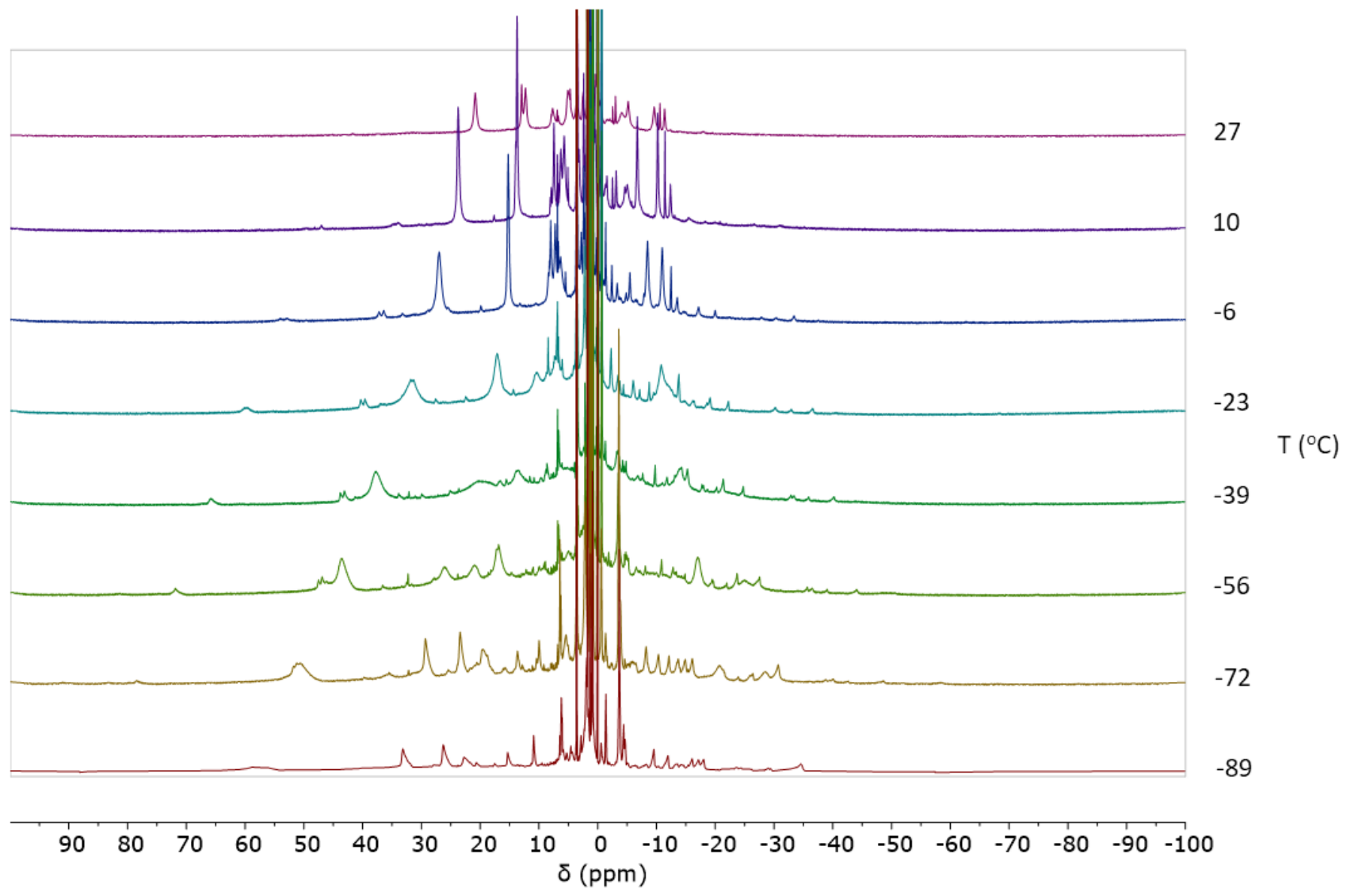

Figure S24. ${ }^{1} \mathrm{H}$ variable temperature NMR spectrum of $\mathrm{U}(\mathrm{TDA})_{3}(2)$ in $\mathrm{d}_{8}-\mathrm{THF}$. Although we are not able to assign the peaks in these spectra, amidate ligands are well-documented to undergo fluxional changes in coordination modes in solution; it has been reported that cooling transition metal amidate complexes can yield complicated NMR spectra as the various isomers become unable to interconvert on the NMR timescale., 


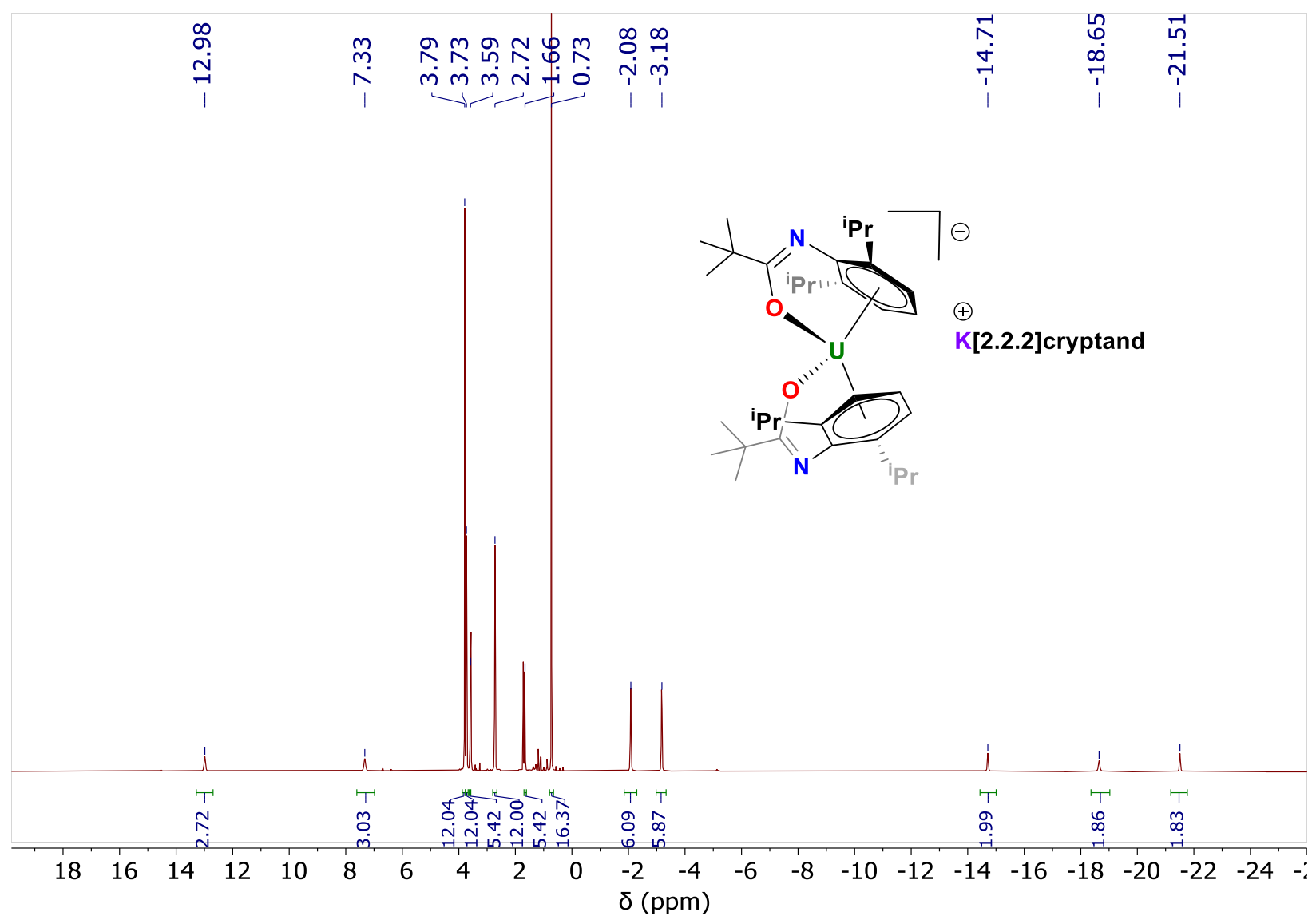

Figure S25. ${ }^{1} \mathrm{H}$ NMR spectrum of $\left.[\mathrm{K}[2.2 .2] \text { cryptand][U(TDA) })_{2}\right]$ (3) in $\mathrm{d}_{8}$-THF at room temperature (collected within 10 minutes after sample preparation to minimize the presence of thermal decomposition products). 


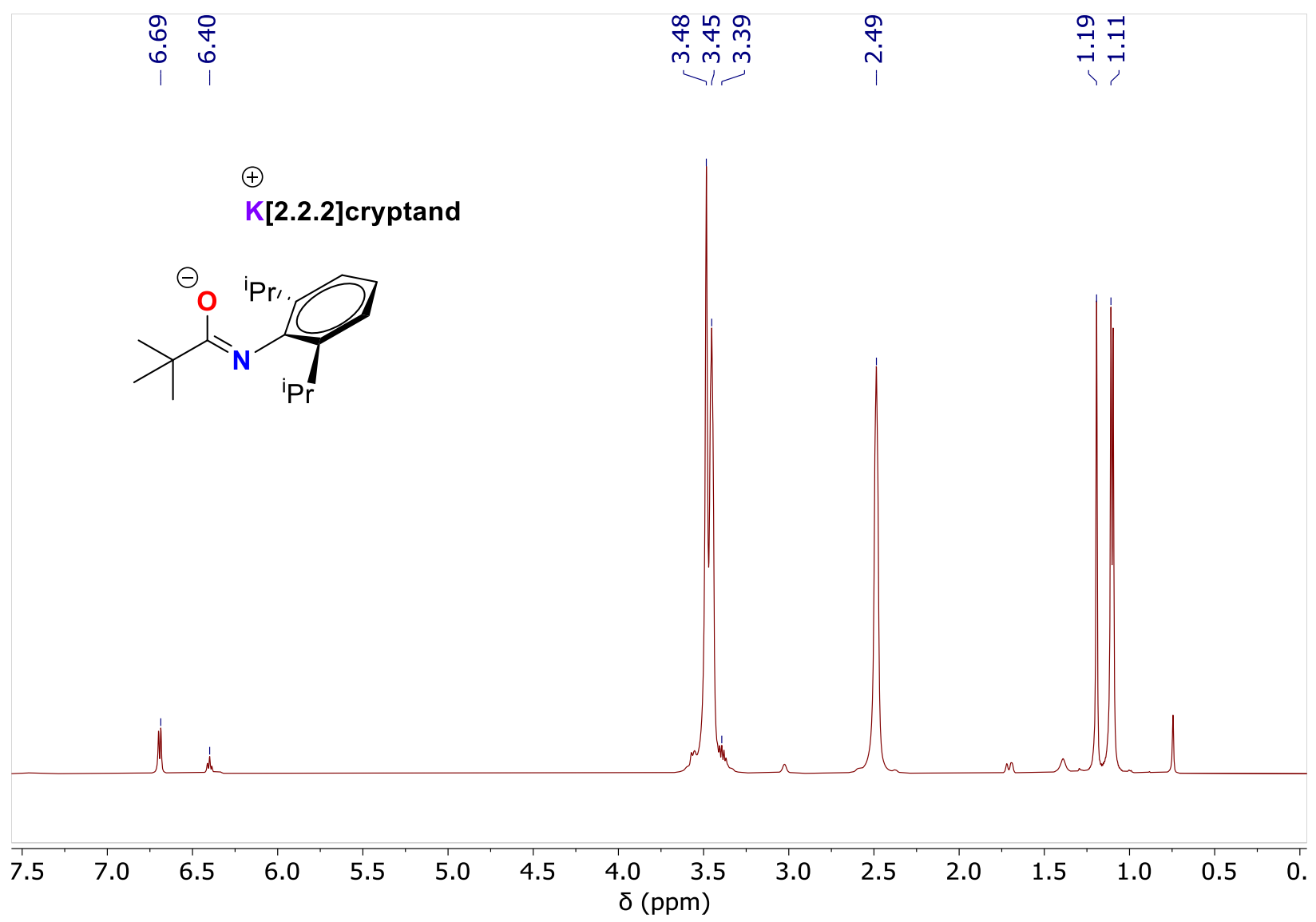

Figure S26. ${ }^{1} \mathrm{H}$ NMR spectrum in $\mathrm{d}_{8}$-THF of $\mathrm{K}$ (TDA)[2.2.2] cryptand formed as a side product during the synthesis of $[\mathrm{K}[2.2 .2]$ cryptand][U(TDA) 2$](3)$. 


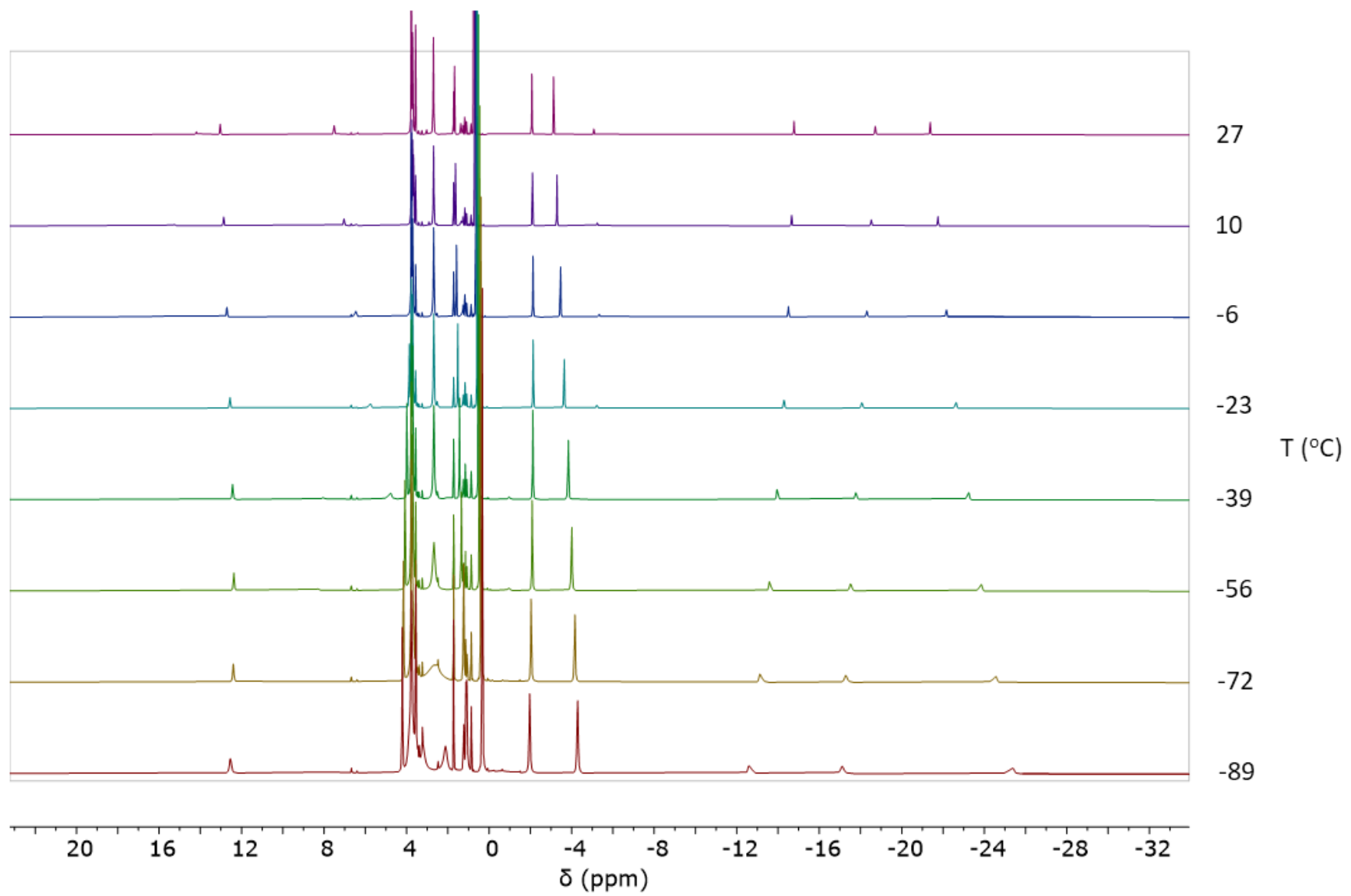

Figure S27. ${ }^{1} \mathrm{H}$ variable temperature NMR spectrum of [K[2.2.2]cryptand][U(TDA $\left.)_{2}\right](3)$ in $\mathrm{d}_{8^{-}}$ THF. No change in symmetry is observed within this temperature range, as evidenced by the lack of splitting, appearance, or disappearance of any peaks corresponding to 3 . 


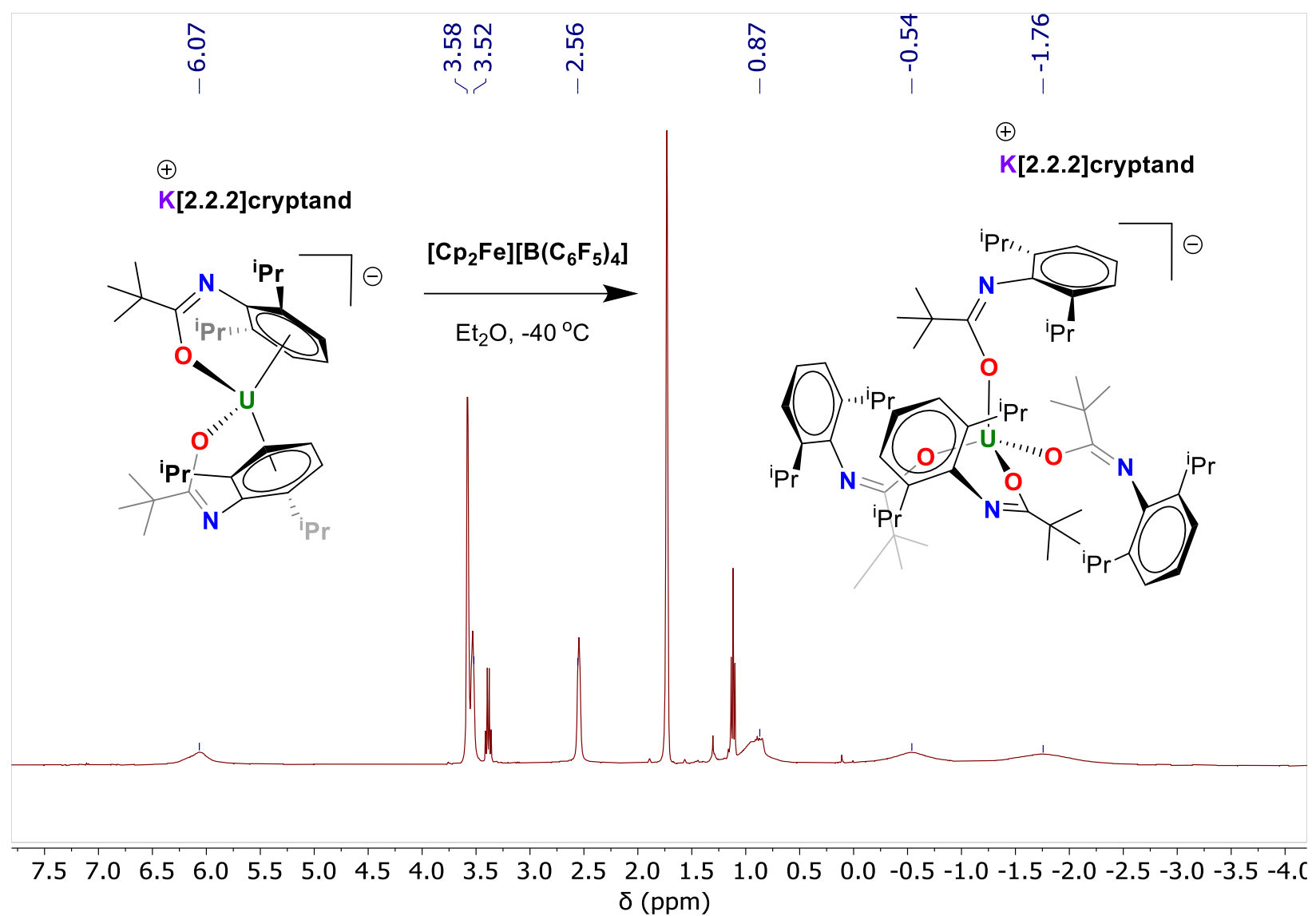

Figure S28. ${ }^{1} \mathrm{H}$ NMR spectrum in $\mathrm{d}_{8}$-THF of the products formed by reacting [K[2.2.2]cryptand][U(TDA) $\left.)_{2}\right](3)$ with $\left[\mathrm{Cp}_{2} \mathrm{Fe}\right]\left[\mathrm{B}\left(\mathrm{C}_{6} \mathrm{~F}_{5}\right)_{4}\right]$, washing with hexane, and extracting into $\mathrm{Et}_{2} \mathrm{O}$. The peaks at 6.07, 3.52, 2.56, 0.87, -0.54, and -1.76 are from [K[2.2.2]cryptand][U(TDA) 4 (1-crypt); another peak from this compound is hidden by the $\mathrm{d}_{8}$ THF solvent peak at $3.58 \mathrm{ppm}$. The peaks at 1.11 and 3.26 are from residual $\mathrm{Et}_{2} \mathrm{O}$. 


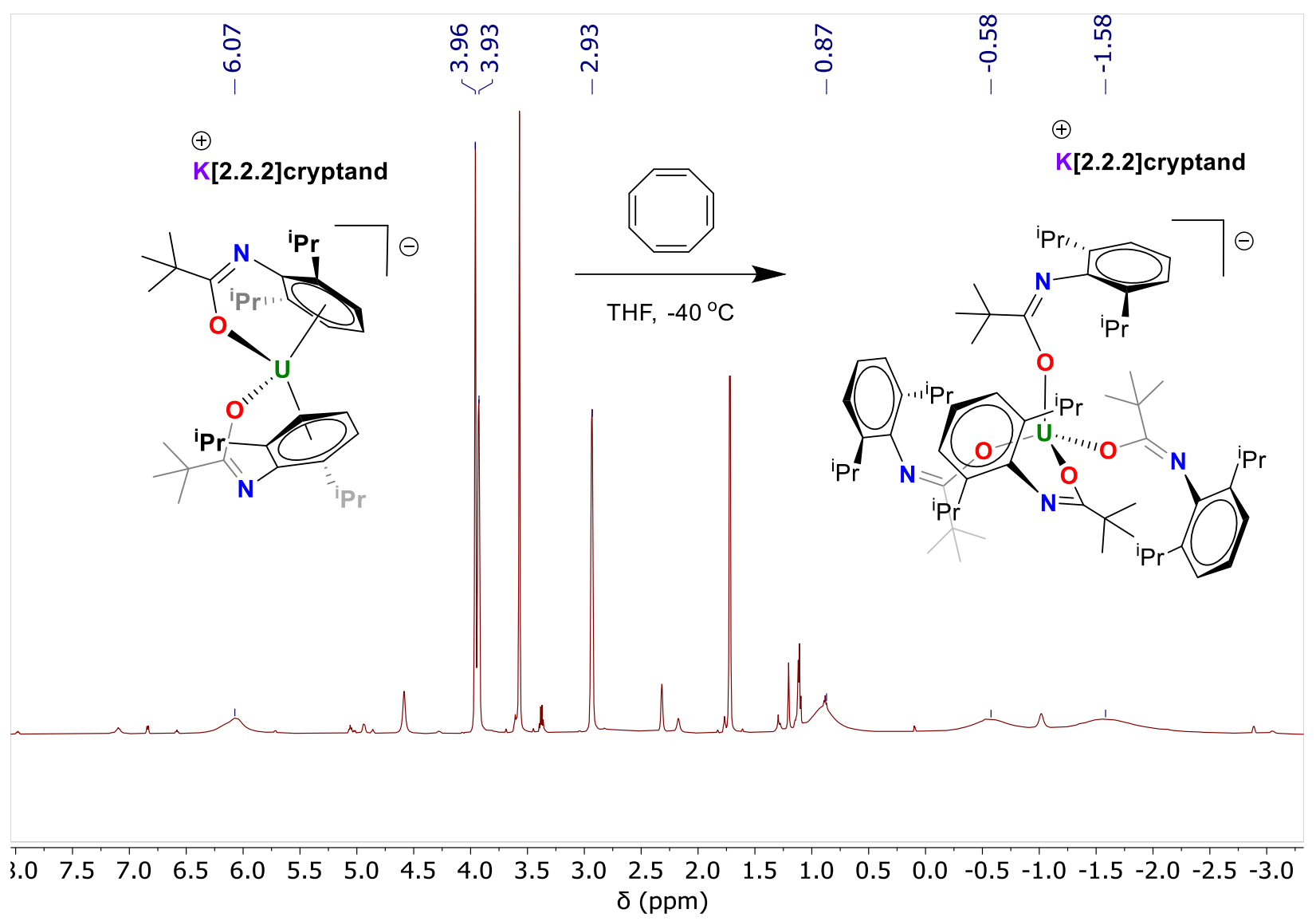

Figure S29. ${ }^{1} \mathrm{H}$ NMR spectrum in $\mathrm{d}_{8}$-THF of the products crystallized from $\mathrm{Et}_{2} \mathrm{O}$ after reacting $[\mathrm{K}[2.2 .2]$ cryptand][U(TDA) 2$](3)$ with COT. The peaks at $6.07,3.96,3.93,2.93,0.87,-0.58$, and -1.58 are from $[\mathrm{K}[2.2 .2]$ cryptand][U(TDA) 4 (1-crypt). 


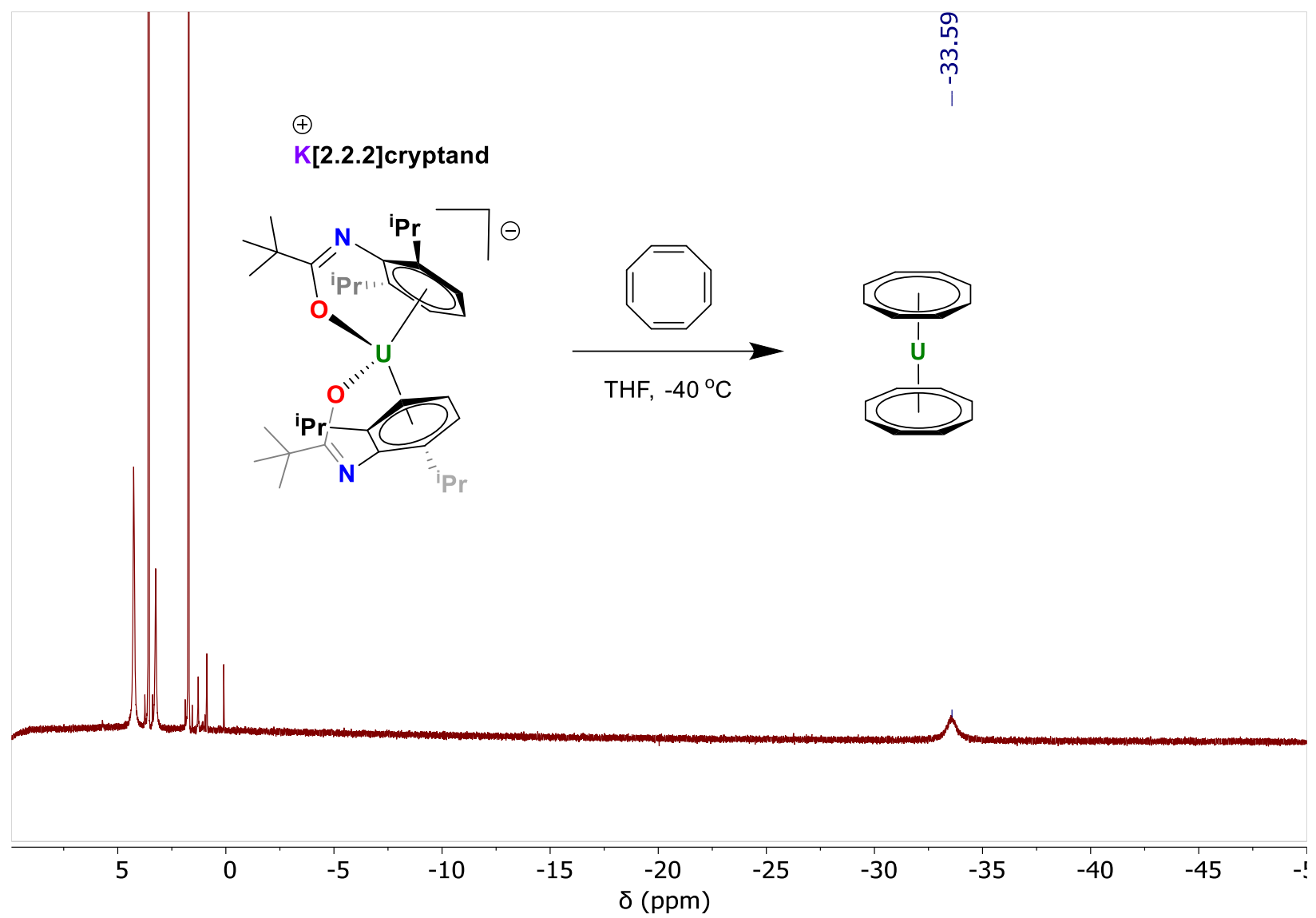

Figure S30. ${ }^{1} \mathrm{H}$ NMR spectrum in $\mathrm{d}_{8}$-THF of the products crystallized from THF after reacting $\left[\mathrm{K}[2.2 .2]\right.$ cryptand] $\left[\mathrm{U}(\mathrm{TDA})_{2}\right](3)$ with $\mathrm{COT} . \quad \mathrm{U}\left(\eta^{8}-\mathrm{C}_{8} \mathrm{H}_{8}\right)_{2}$, the major product, appears as a singlet at -33.59 ppm. ${ }^{9}$ 


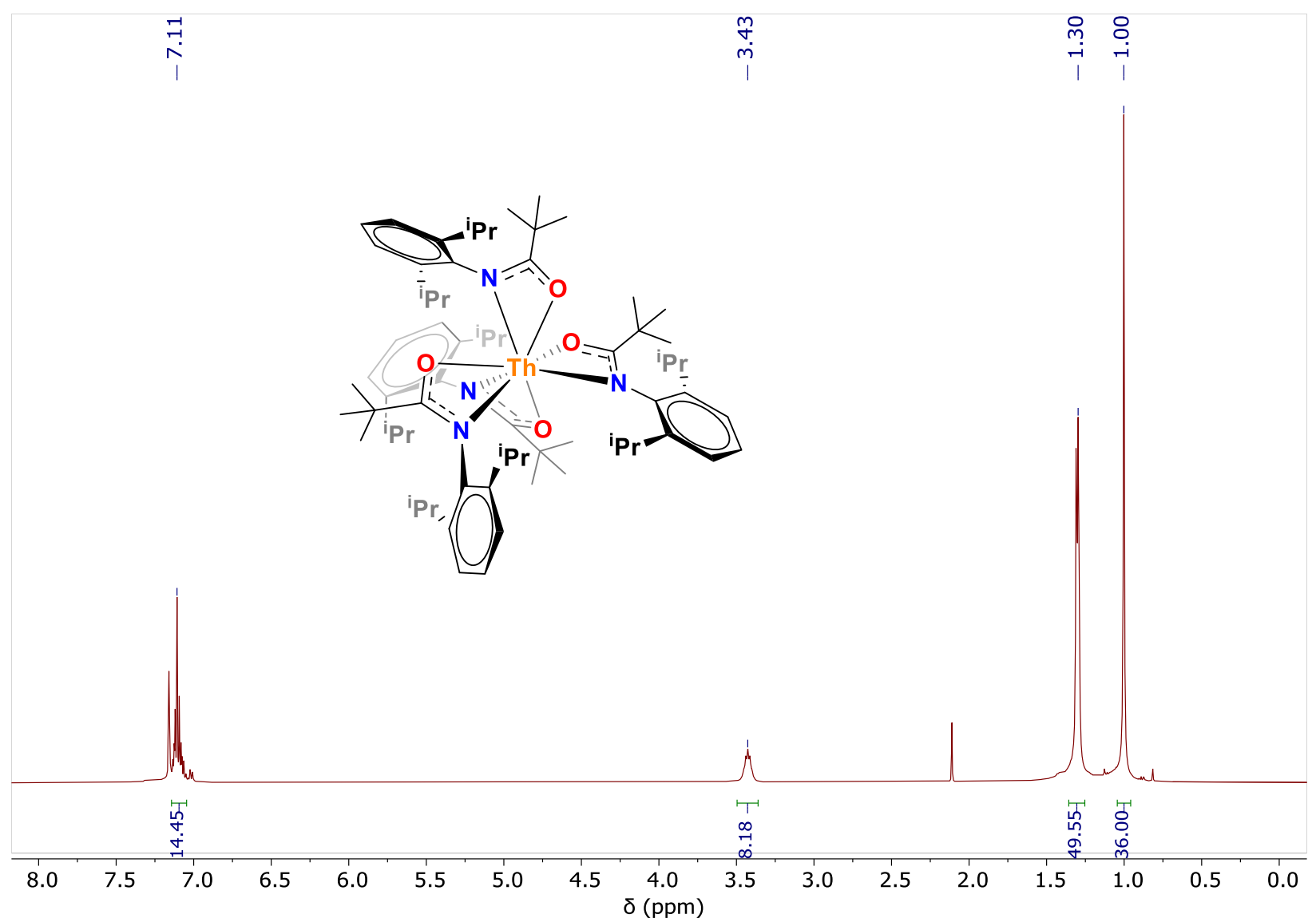

Figure S31. ${ }^{1} \mathrm{H}$ NMR spectrum of $\mathrm{Th}(\mathrm{TDA})_{4}(4)$ in $\mathrm{C}_{6} \mathrm{D}_{6}$. The small peaks at $2.11,7.02$, and $7.13 \mathrm{ppm}$ are from residual toluene. 


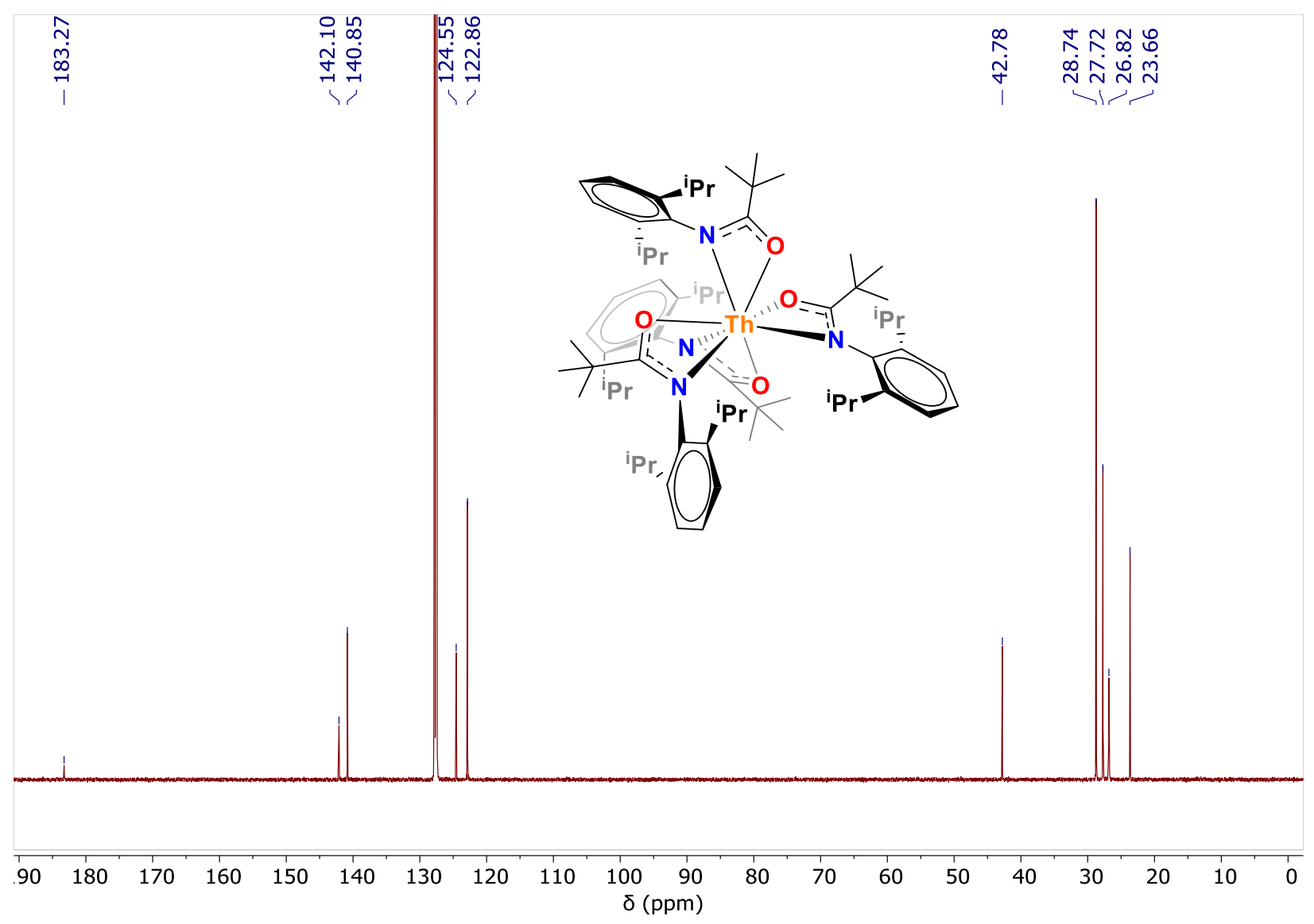

Figure S32. ${ }^{13} \mathrm{C}$ NMR spectrum of $\mathrm{Th}(\mathrm{TDA})_{4}(4)$ in $\mathrm{C}_{6} \mathrm{D}_{6}$. 


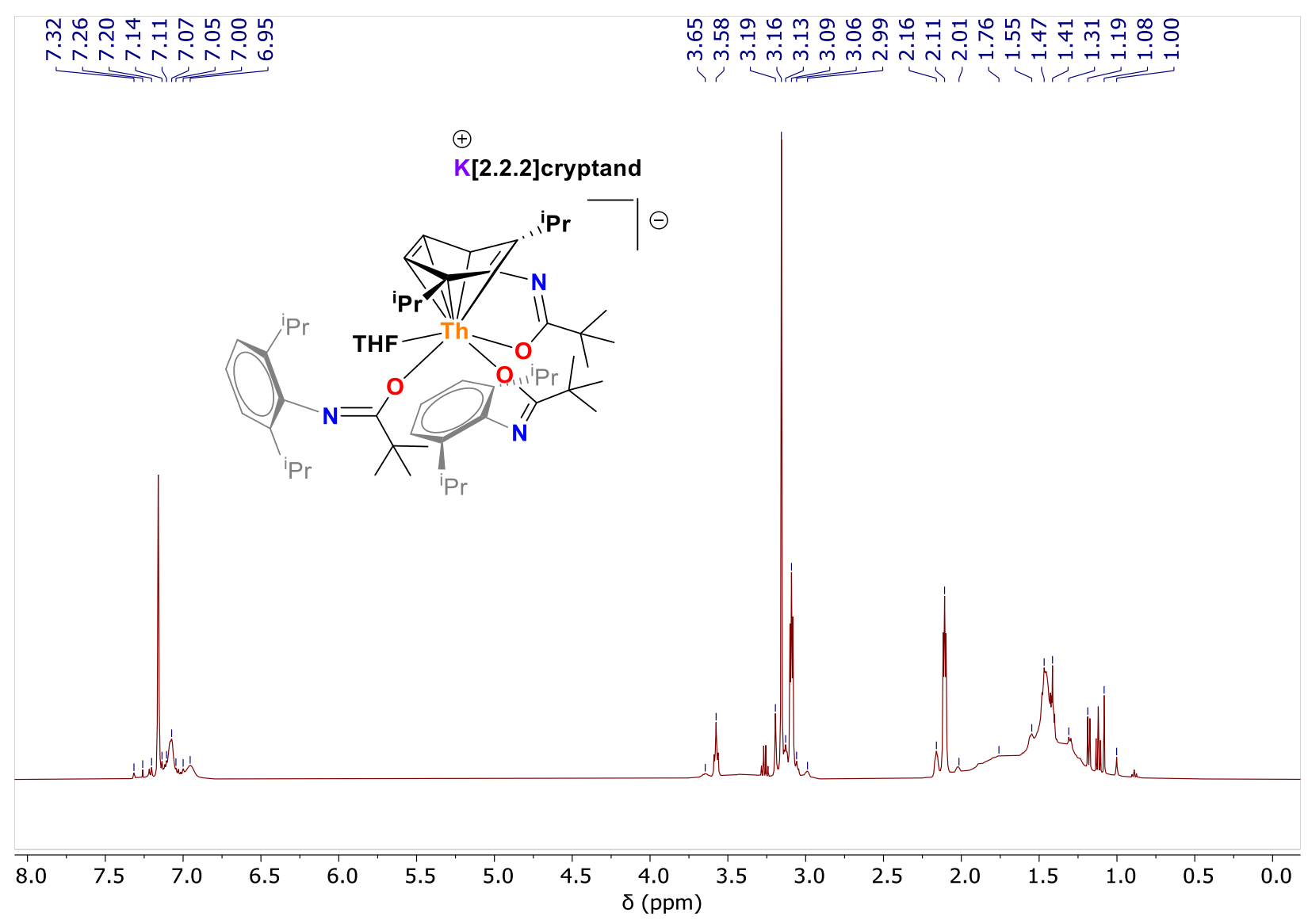

Figure S33. ${ }^{1} \mathrm{H}$ NMR spectrum of $\left[\mathrm{K}[2.2 .2]\right.$ cryptand] $\left[\mathrm{Th}(\mathrm{TDA})_{3}(\mathrm{THF})\right](\mathbf{5})$ in $\mathrm{C}_{6} \mathrm{D}_{6}$ (collected within 10 minutes after sample preparation to minimize the presence of thermal decomposition products). 


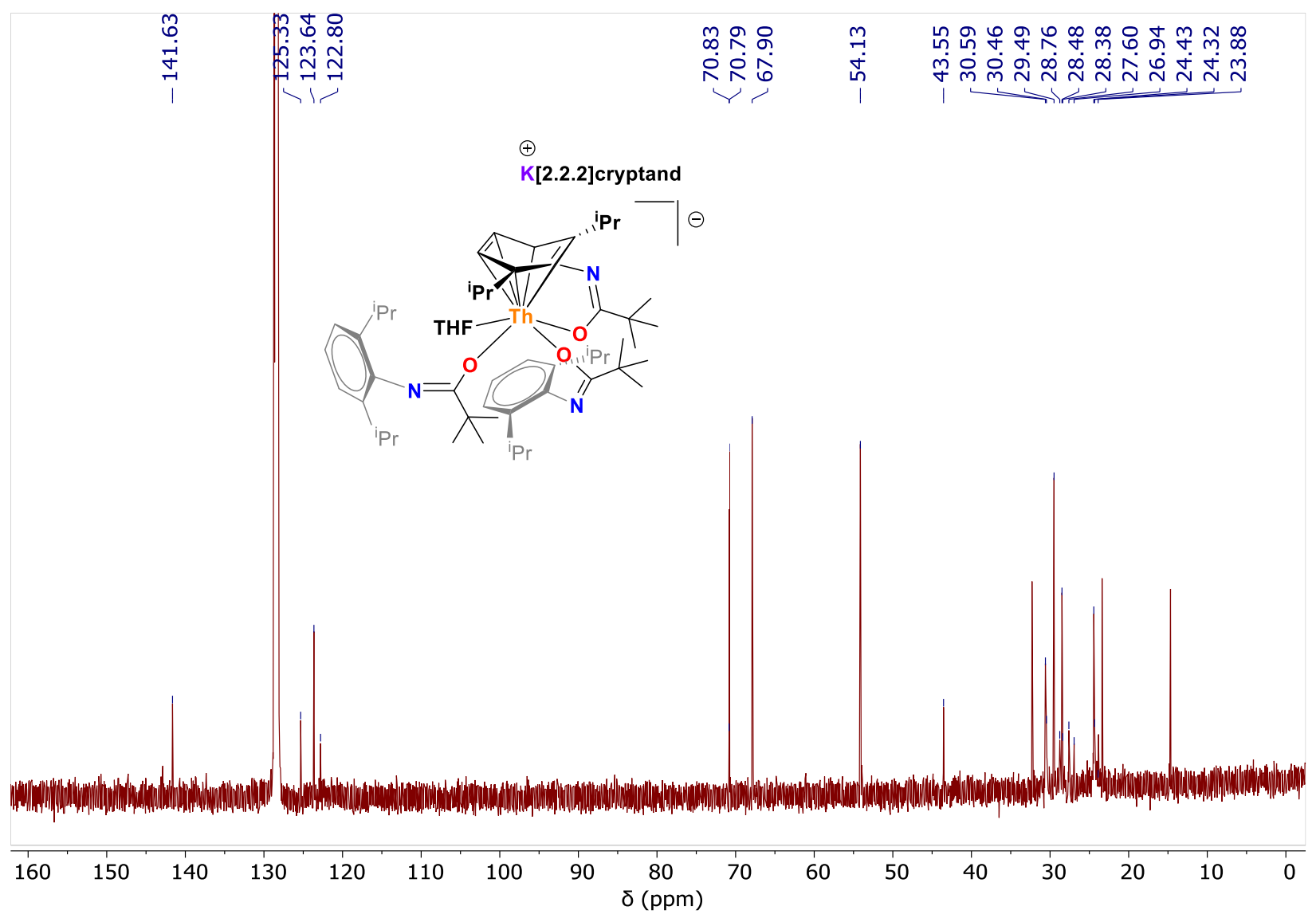

Figure S34. ${ }^{13} \mathrm{C}$ NMR spectrum of $\left[\mathrm{K}[2.2 .2]\right.$ cryptand] $\left[\mathrm{Th}(\mathrm{TDA})_{3}(\mathrm{THF})\right](\mathbf{5})$ in $\mathrm{C}_{6} \mathrm{D}_{6}$. The peaks at $14.68,23.38$, and $32.29 \mathrm{ppm}$ are from residual hexane. 


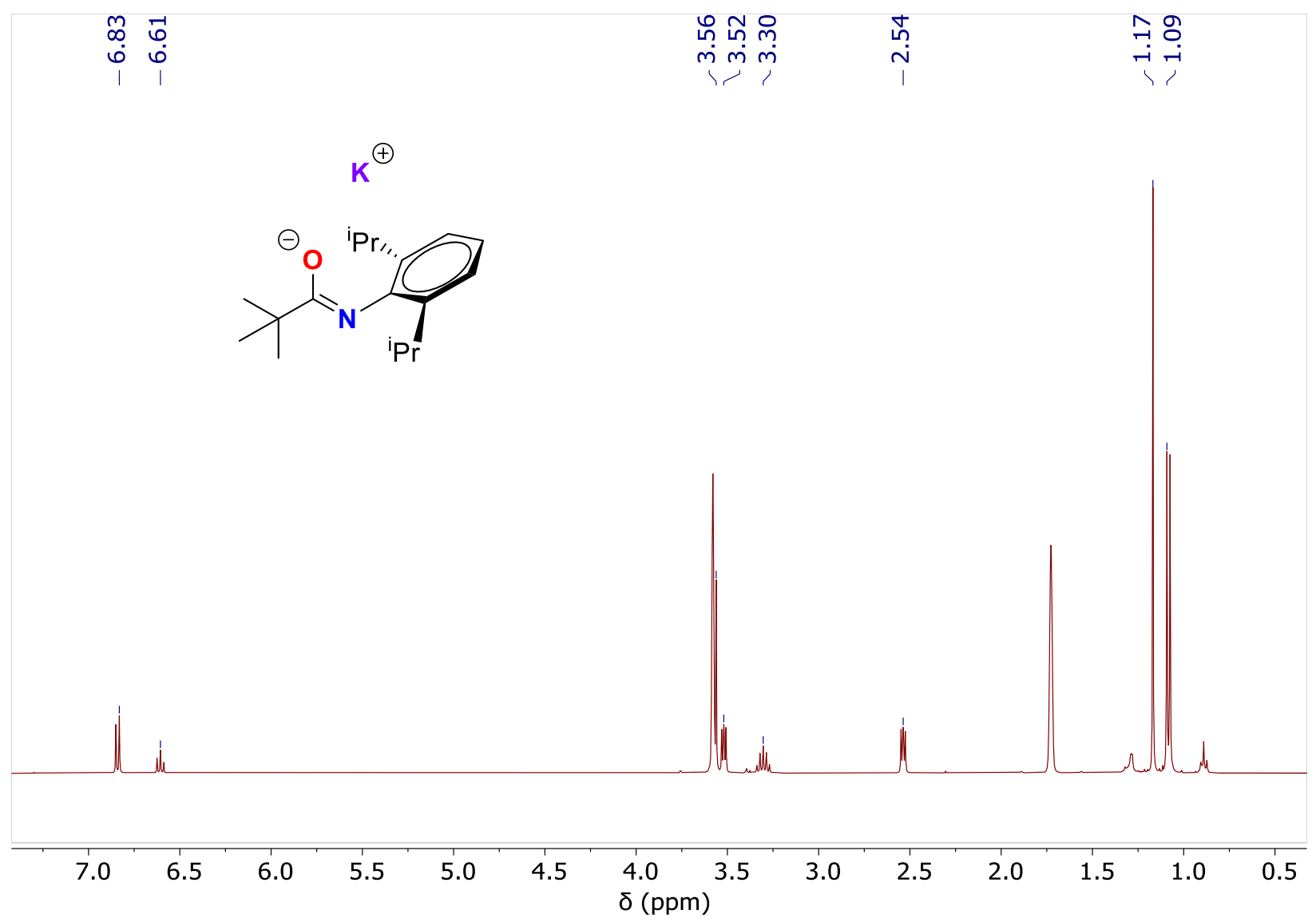

Figure S35. ${ }^{1} \mathrm{H}$ NMR spectrum in $\mathrm{d}_{8}$-THF of $\mathrm{K}(\mathrm{TDA})$ formed as a side product during the synthesis of $[\mathrm{K}[2.2 .2]$ cryptand $]\left[\mathrm{Th}(\mathrm{TDA})_{3}(\mathrm{THF})\right](\mathbf{5})$. 


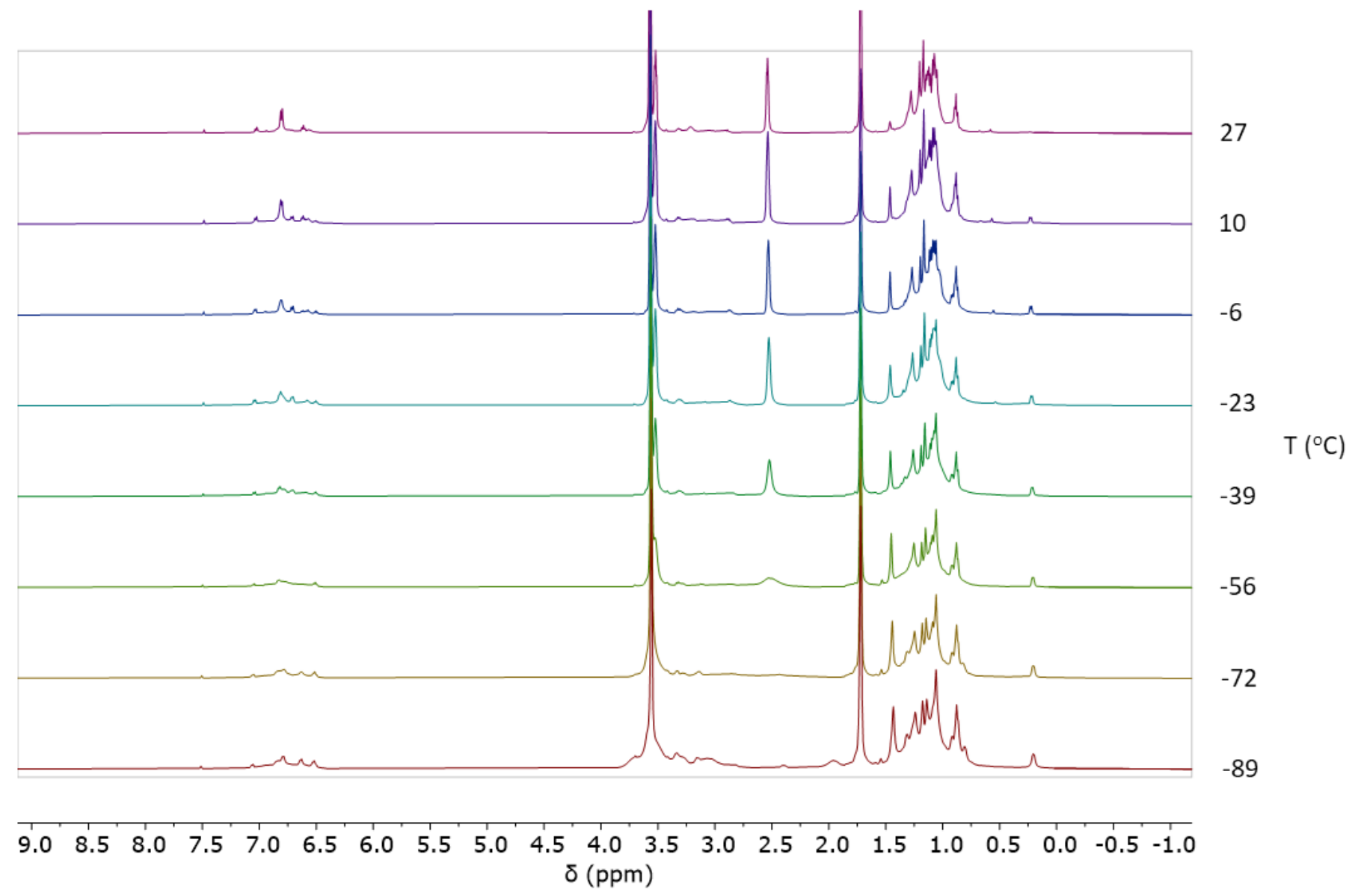

Figure S36. ${ }^{1} \mathrm{H}$ variable temperature NMR spectrum of $[\mathrm{K}[2.2 .2]$ cryptand $]\left[\mathrm{Th}(\mathrm{TDA})_{3}(\mathrm{THF})\right](\mathbf{5})$ in $\mathrm{d}_{8}$-THF. No significant change is observed for the peaks corresponding to [Th(TDA) 3 (THF)] but the cryptand peak at $c a$. 2.5 ppm splits into two separate peaks at low temperature as the two possible conformations of ethylene linkers in the cryptand moiety can no longer interconvert on the NMR timescale. 

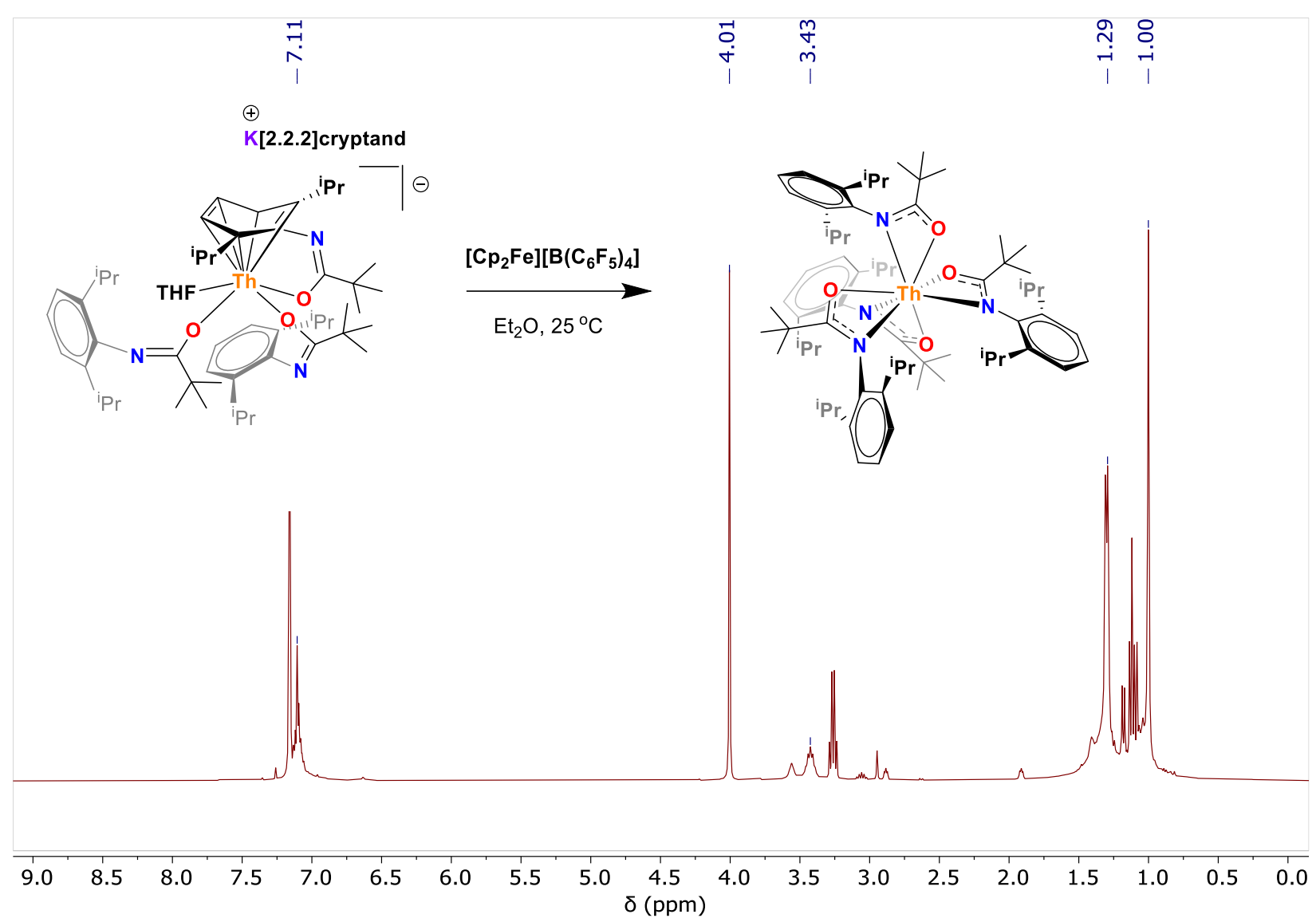

Figure S37. ${ }^{1} \mathrm{H}$ NMR spectrum in $\mathrm{C}_{6} \mathrm{D}_{6}$ of the products formed by reacting $\left[\mathrm{K}[2.2 .2]\right.$ cryptand] $\left[\mathrm{Th}(\mathrm{TDA})_{3}(\mathrm{THF})\right](\mathbf{5})$ with $\left[\mathrm{Cp}_{2} \mathrm{Fe}\right]\left[\mathrm{B}\left(\mathrm{C}_{6} \mathrm{~F}_{5}\right)_{4}\right]$. The peaks at 7.11, 3.43, 1.29, and $1.00 \mathrm{ppm}$ are from $\mathrm{Th}(\mathrm{TDA})_{4}(4)$, and the peak at $4.01 \mathrm{ppm}$ is from $\mathrm{Cp}_{2} \mathrm{Fe}$. The peaks at 1.11 and 3.26 are from residual $\mathrm{Et}_{2} \mathrm{O}$. 


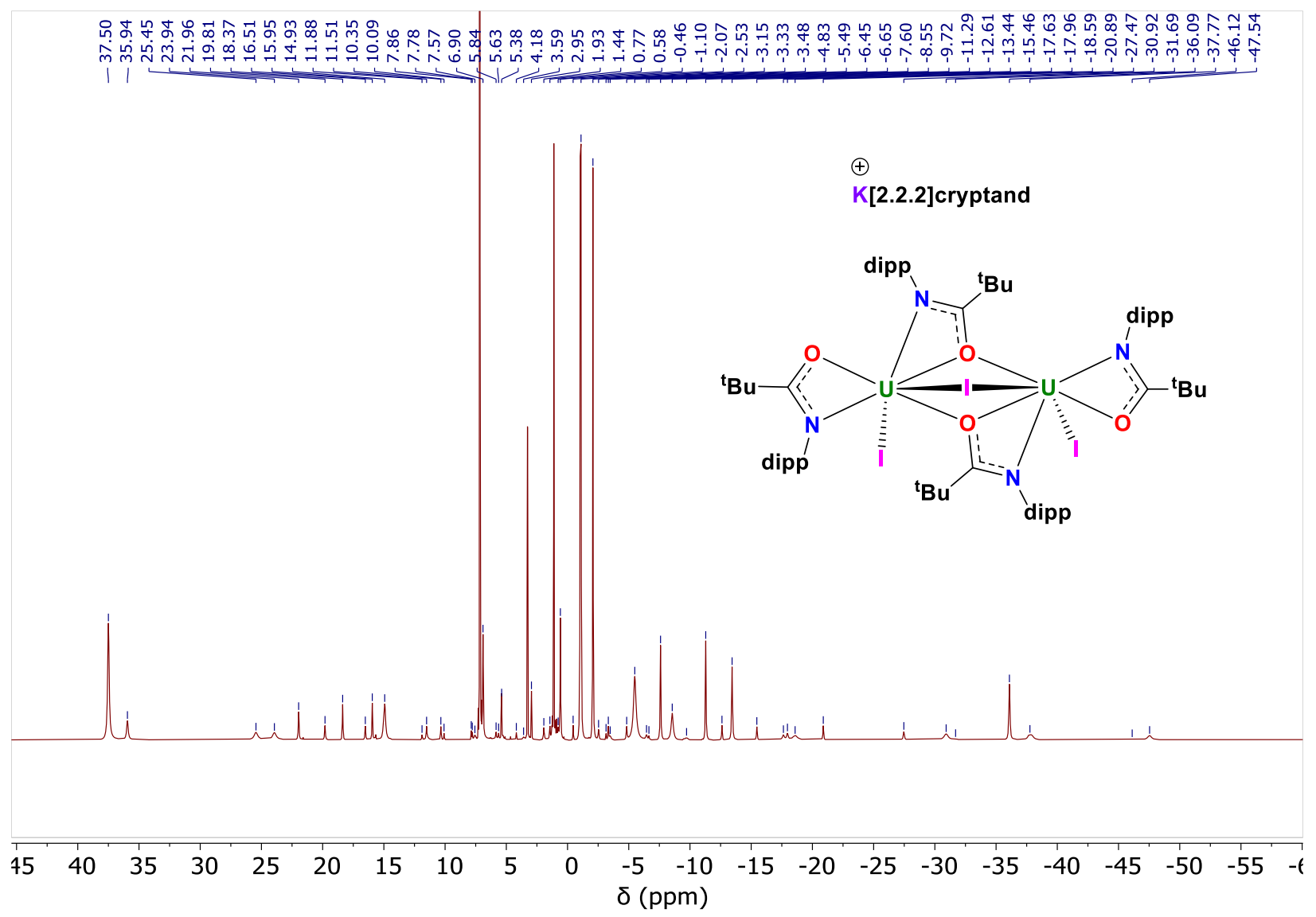

Figure S38. ${ }^{1} \mathrm{H}$ NMR spectrum in $\mathrm{d}_{8}$-THF of [K[2.2.2] cryptand][(UI(TDA $\left.\left.)_{2}\right)_{2}(\mu-\mathrm{I})\right](6)$. 


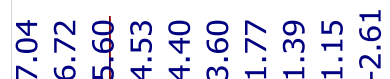

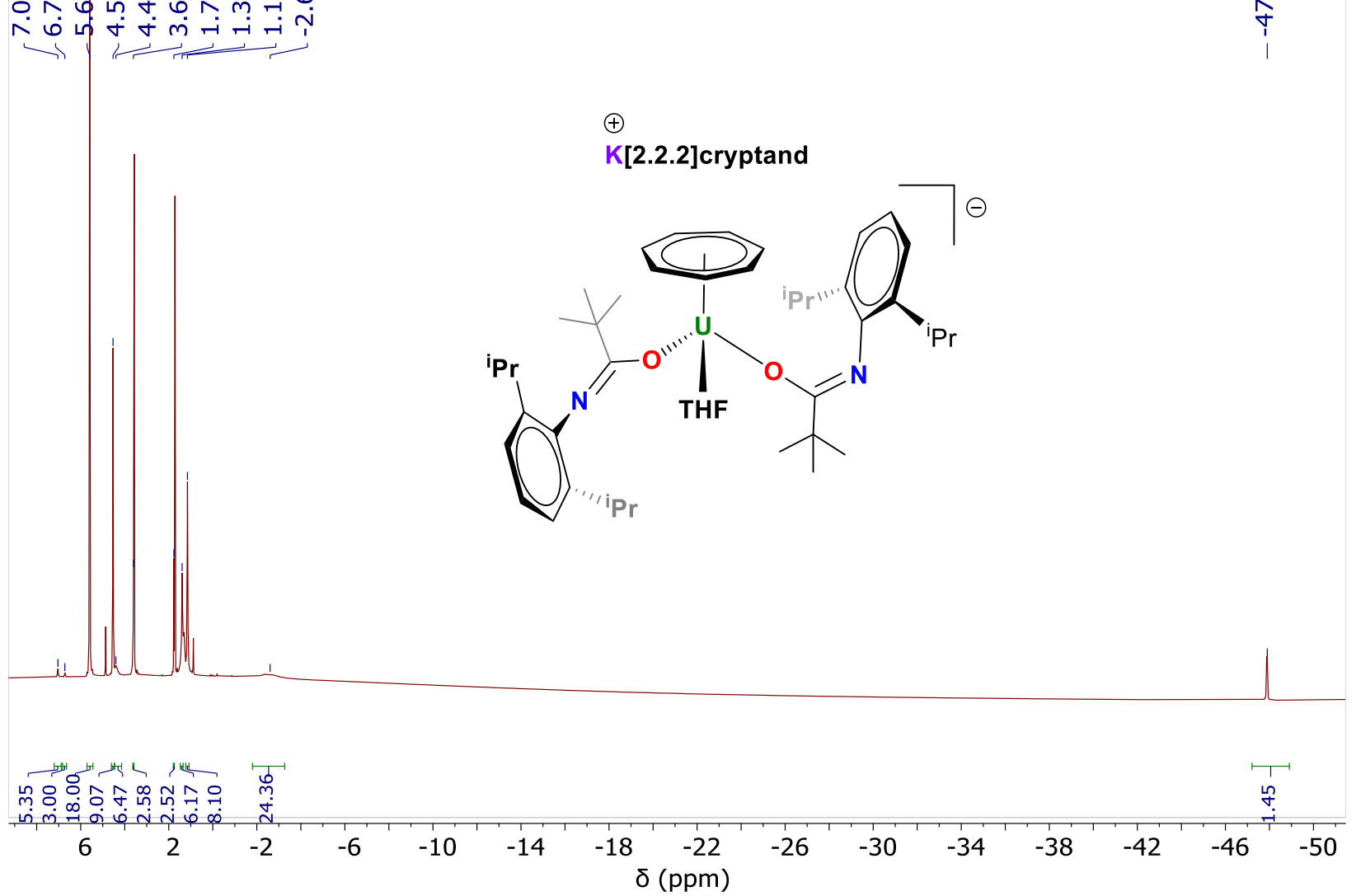

Figure S39. ${ }^{1} \mathrm{H}$ NMR spectrum in $\mathrm{d}_{8}$-THF of $[\mathrm{K}[2.2 .2] \operatorname{cryptand}]\left[\mathrm{U}\left(\eta^{7}-\mathrm{C}_{7} \mathrm{H}_{7}\right)(\mathrm{TDA})_{2}(\mathrm{THF})\right](7)$. 


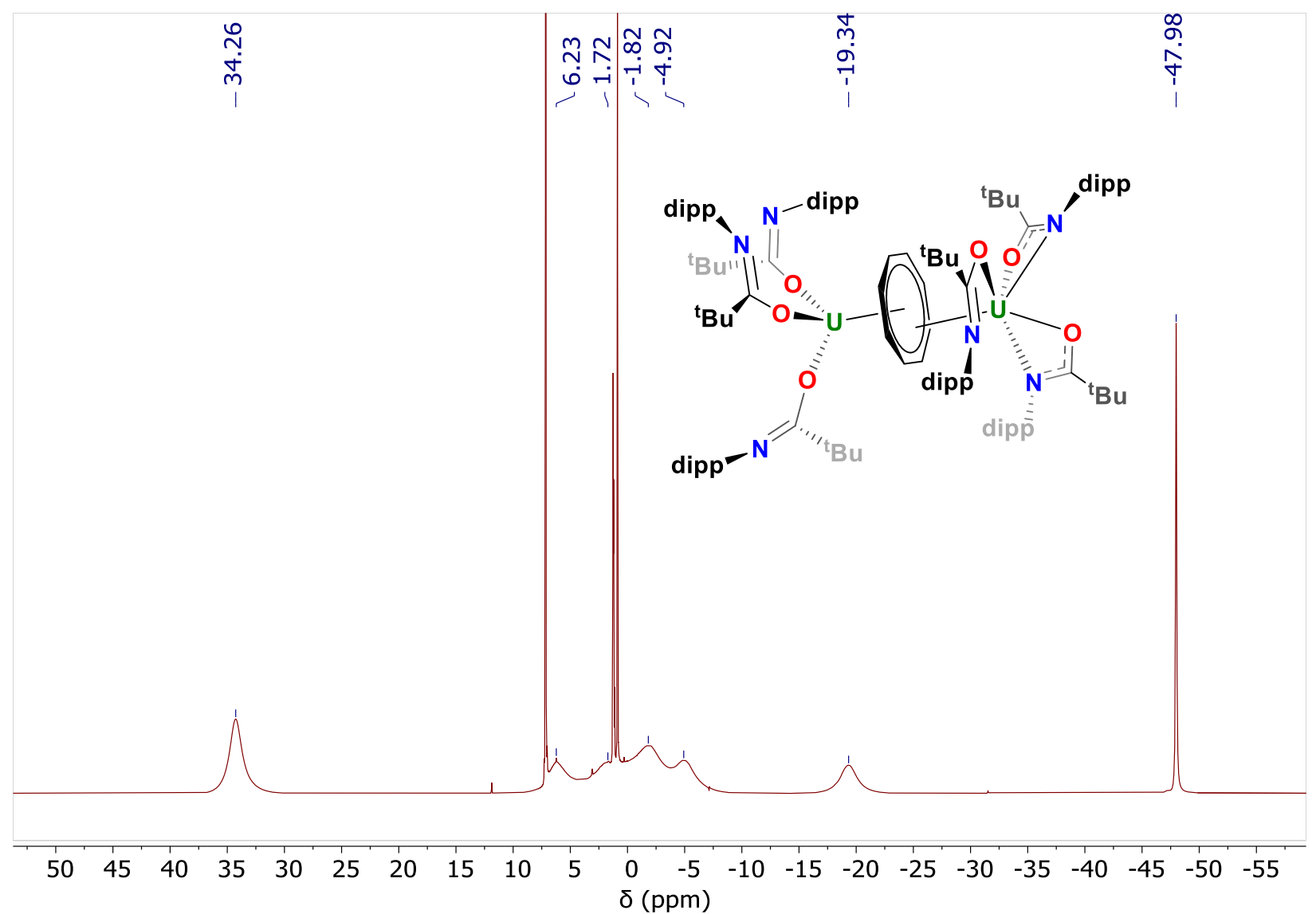

Figure S40. ${ }^{1} \mathrm{H}$ NMR spectrum in $\mathrm{C}_{6} \mathrm{D}_{6}$ of $\left[\mathrm{U}(\mathrm{TDA})_{3}\right]_{2}\left(\mu-\eta^{8}: \eta^{3}-\mathrm{C}_{8} \mathrm{H}_{8}\right)$ (8). A multi-point baseline correction was performed on this spectrum to better distinguish the broad peaks from the baseline. The sharp peaks at 0.89 and $1.23 \mathrm{ppm}$ are from residual pentane. 


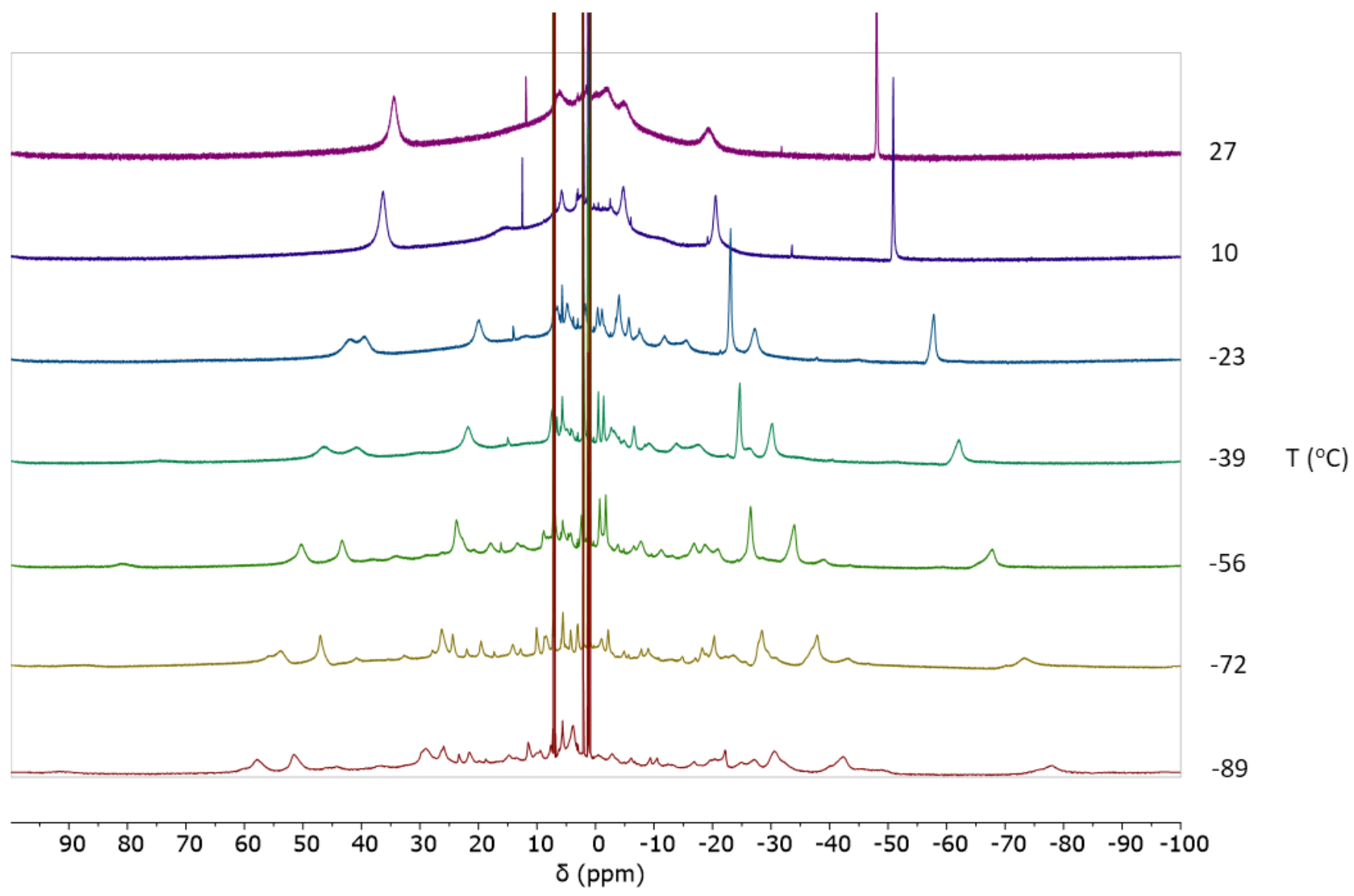

Figure S41. ${ }^{1} \mathrm{H}$ variable temperature NMR spectrum of $\left[\mathrm{U}(\mathrm{TDA})_{3}\right]_{2}\left(\mu-\eta^{8}: \eta^{3}-\mathrm{C}_{8} \mathrm{H}_{8}\right)(\mathbf{8})$ in $\mathrm{d}_{8^{-}}$ toluene. Although we are not able to assign the peaks in these spectra, amidate ligands are welldocumented to undergo fluxional changes in coordination modes in solution; it has been reported that cooling transition metal amidate complexes can yield complicated NMR spectra as the various isomers become unable to interconvert on the NMR timescale. ${ }^{7,8}$ 


\section{G. IR Spectra}

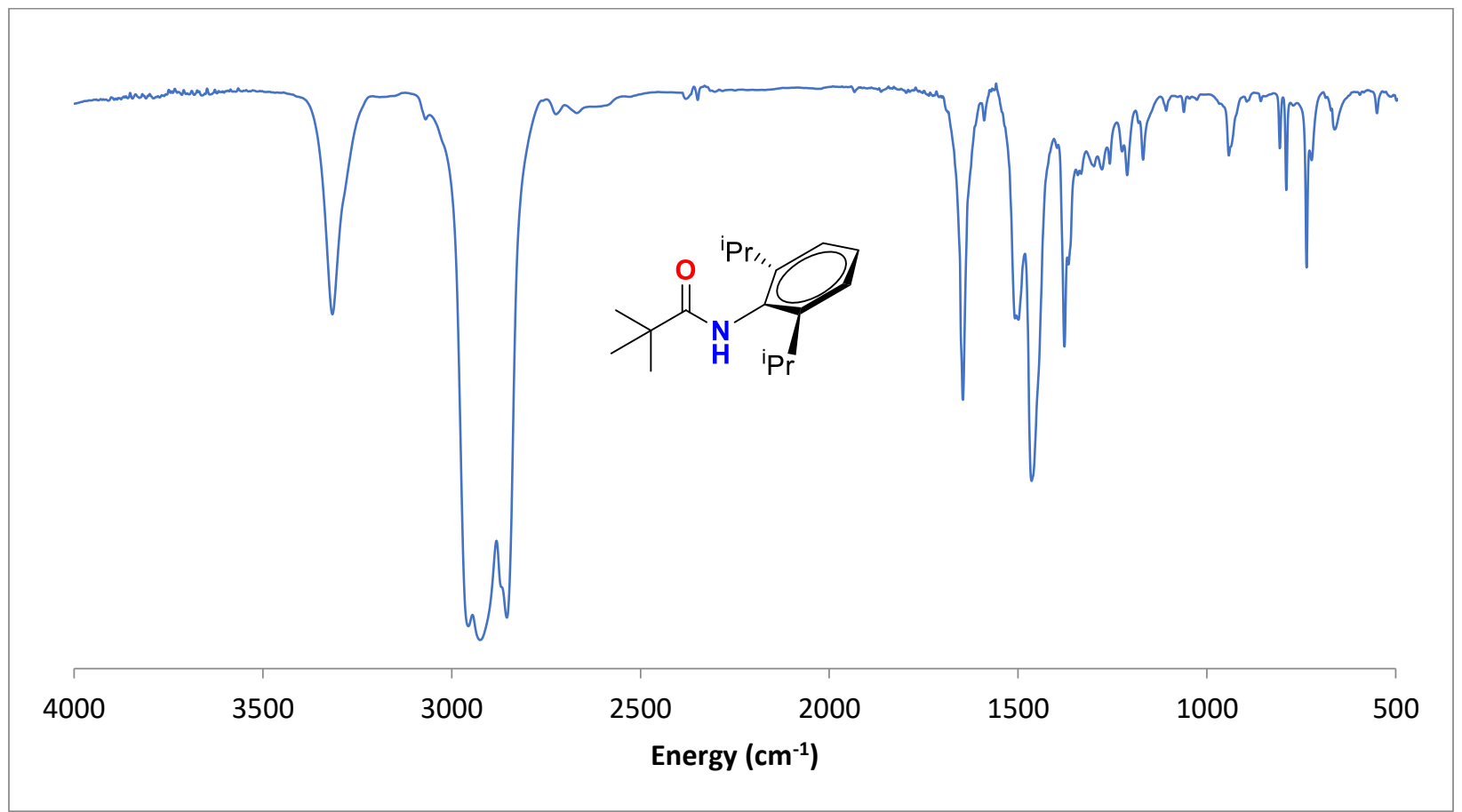

Figure S42. IR spectrum of H(TDA) prepared as a Nujol mull.

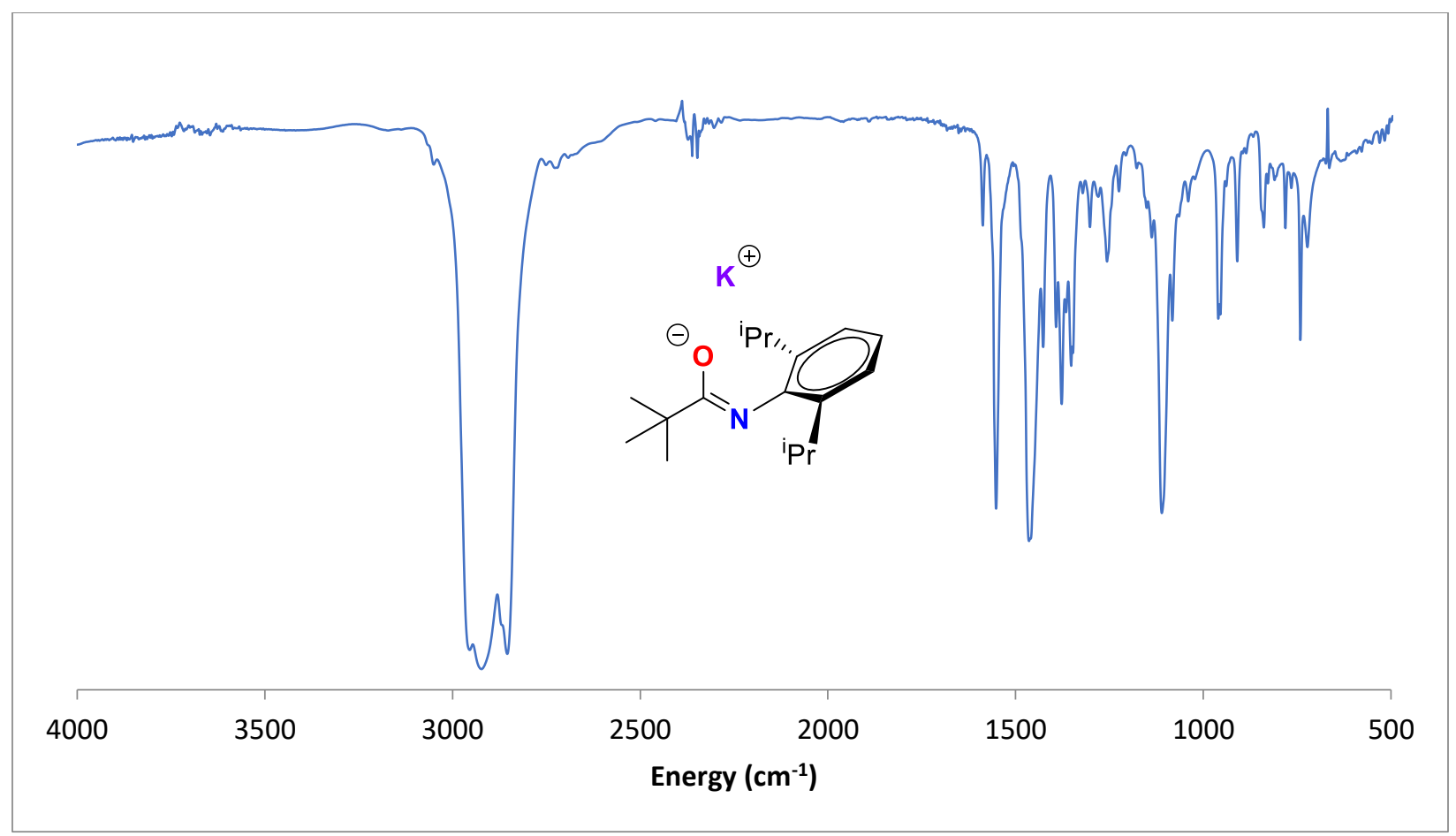

Figure S43. IR spectrum of K(TDA) prepared as a Nujol mull. 


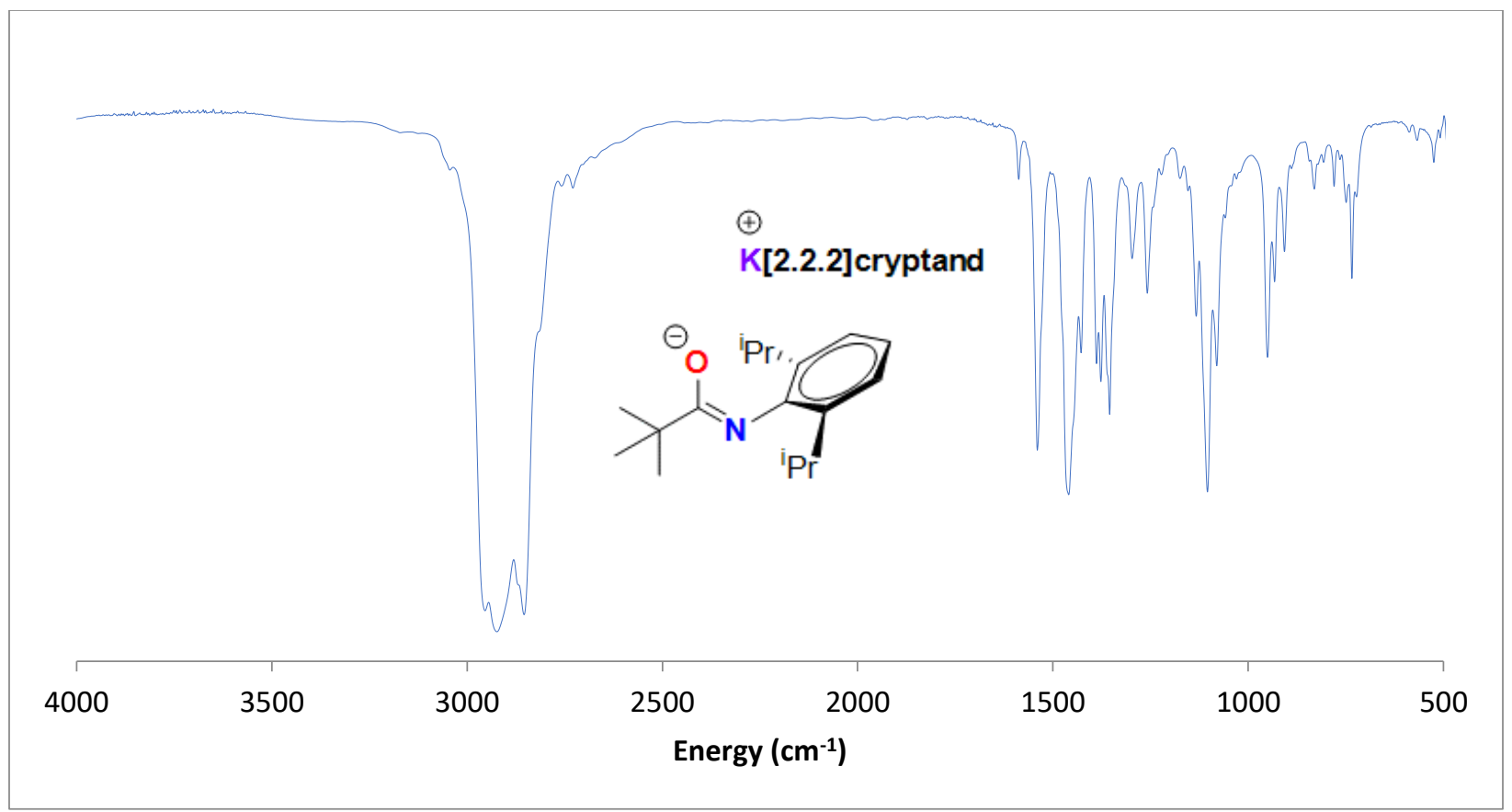

Figure S44. IR spectrum of K(TDA)[2.2.2]cryptand prepared as a Nujol mull.

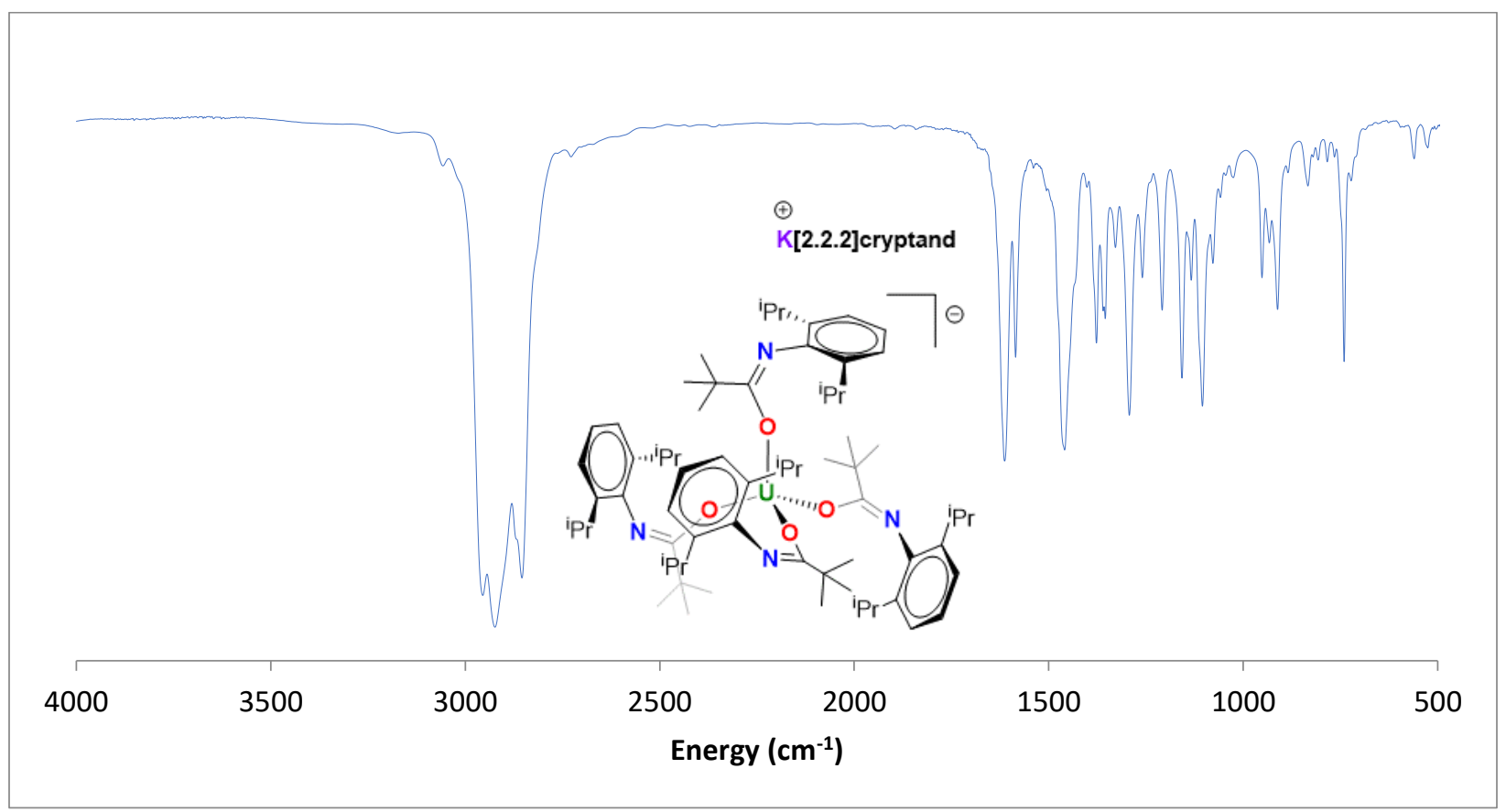

Figure S45. IR spectrum of [K[2.2.2]cryptand][U(TDA) 4 (1-crypt) prepared as a Nujol mull. 


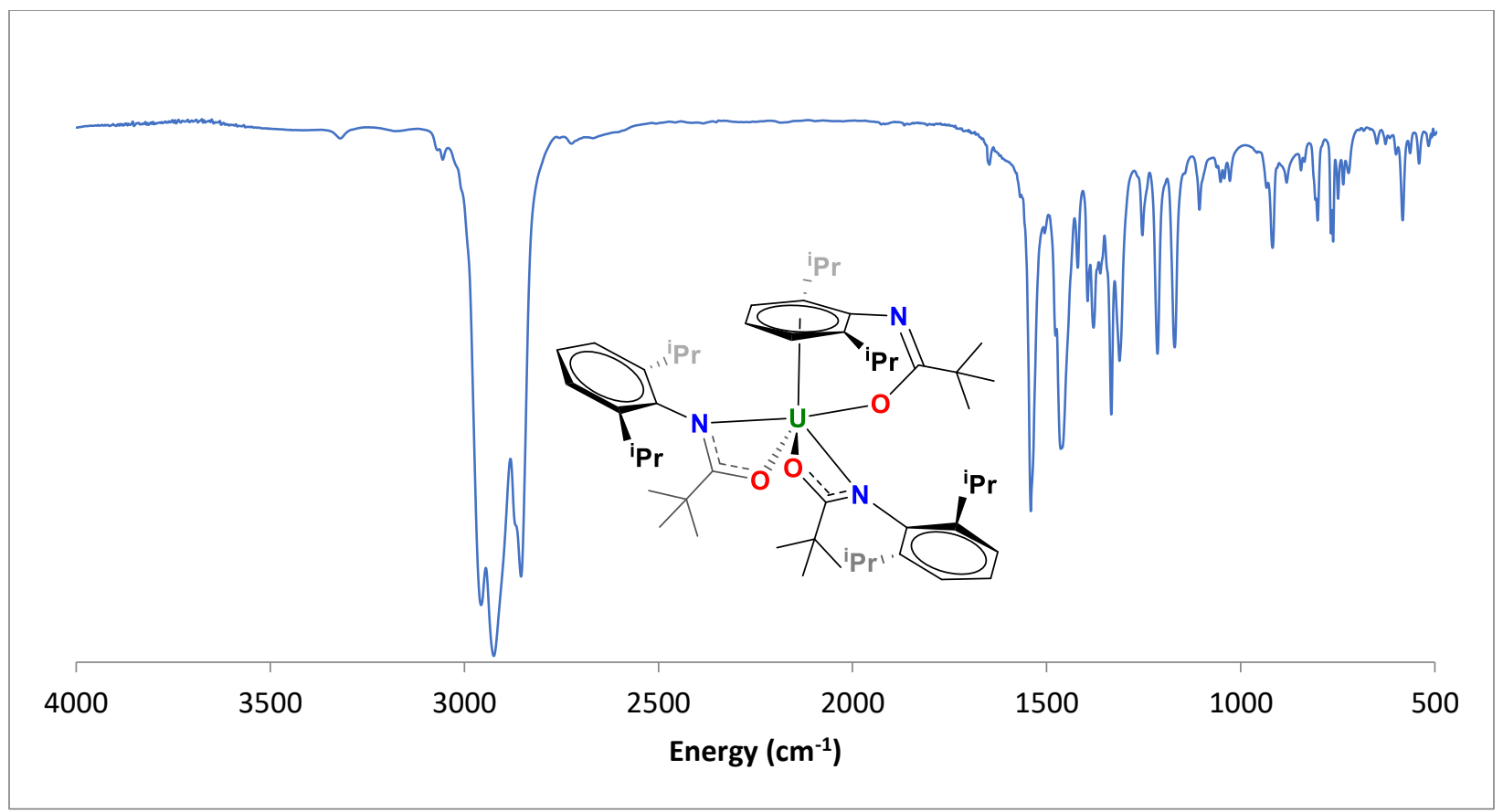

Figure S46. IR spectrum of U(TDA) 3 (2) prepared as a Nujol mull.

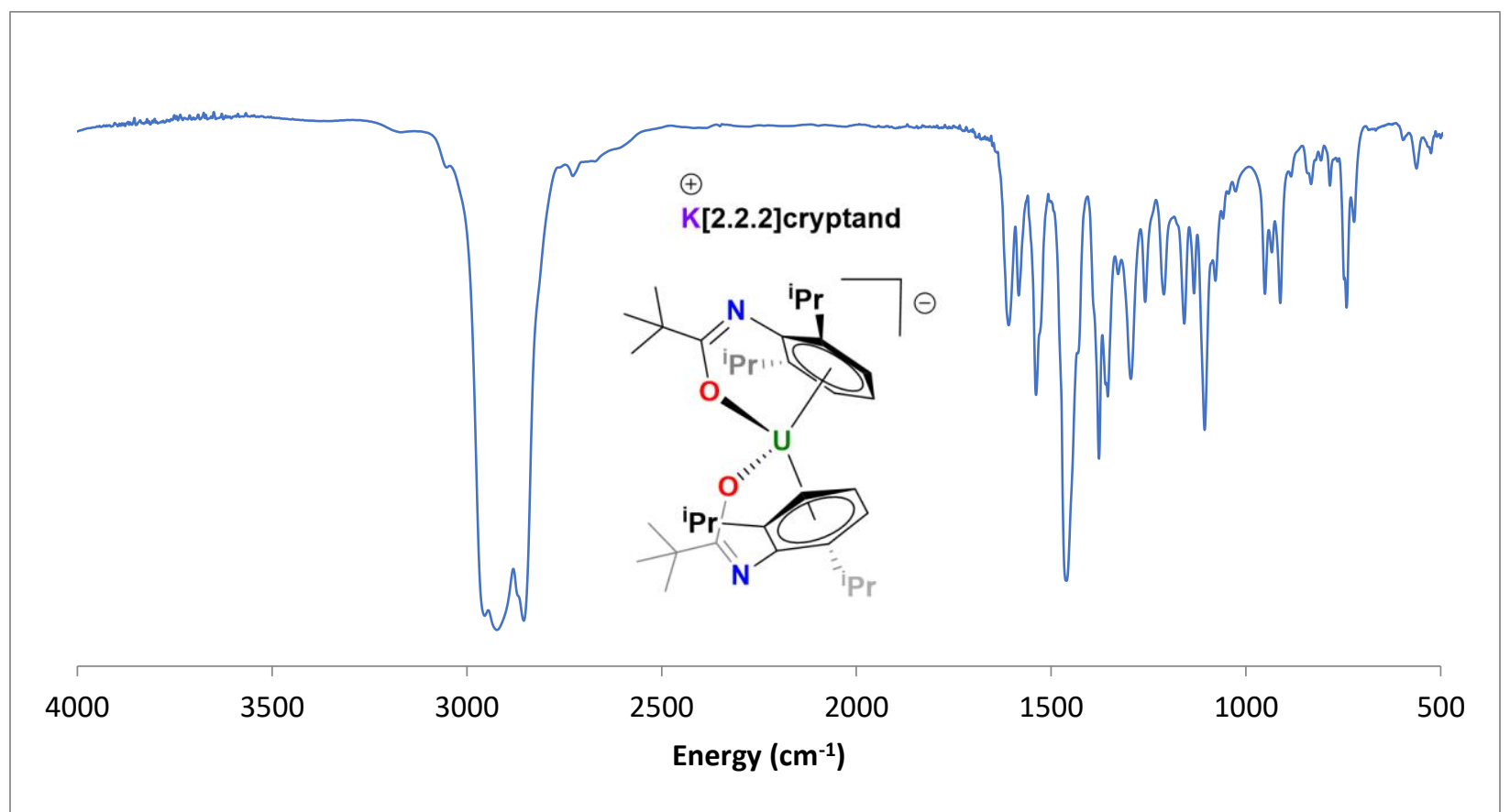

Figure S47. IR spectrum of [K[2.2.2]cryptand][U(TDA) 2$]$ (3) prepared as a Nujol mull. 


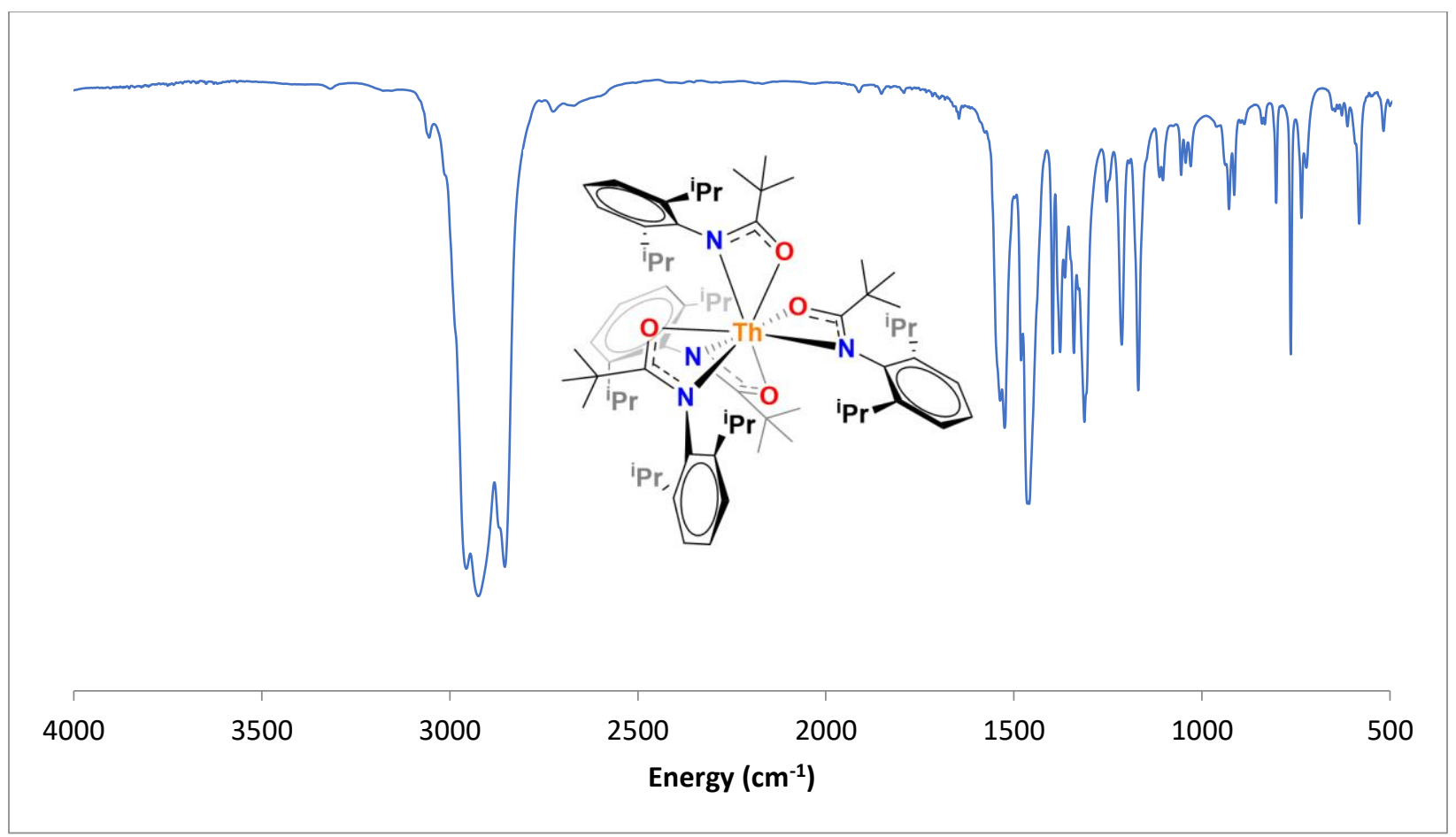

Figure S48. IR spectrum of $\mathrm{Th}(\mathrm{TDA})_{4}(4)$ prepared as a Nujol mull.

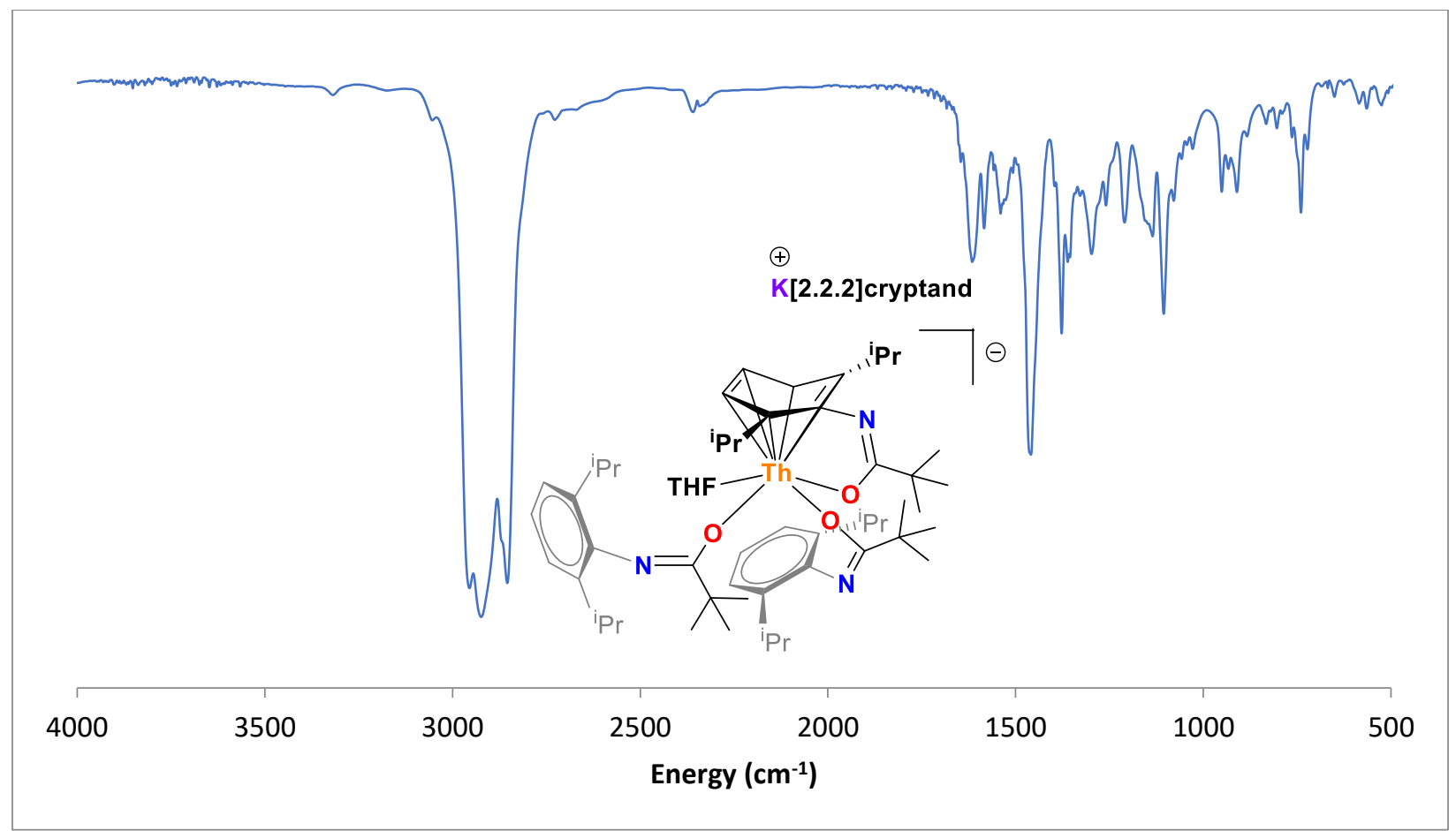

Figure S49. IR spectrum of [K[2.2.2] cryptand][Th(TDA) $3(\mathrm{THF})](5)$ prepared as a Nujol mull. 


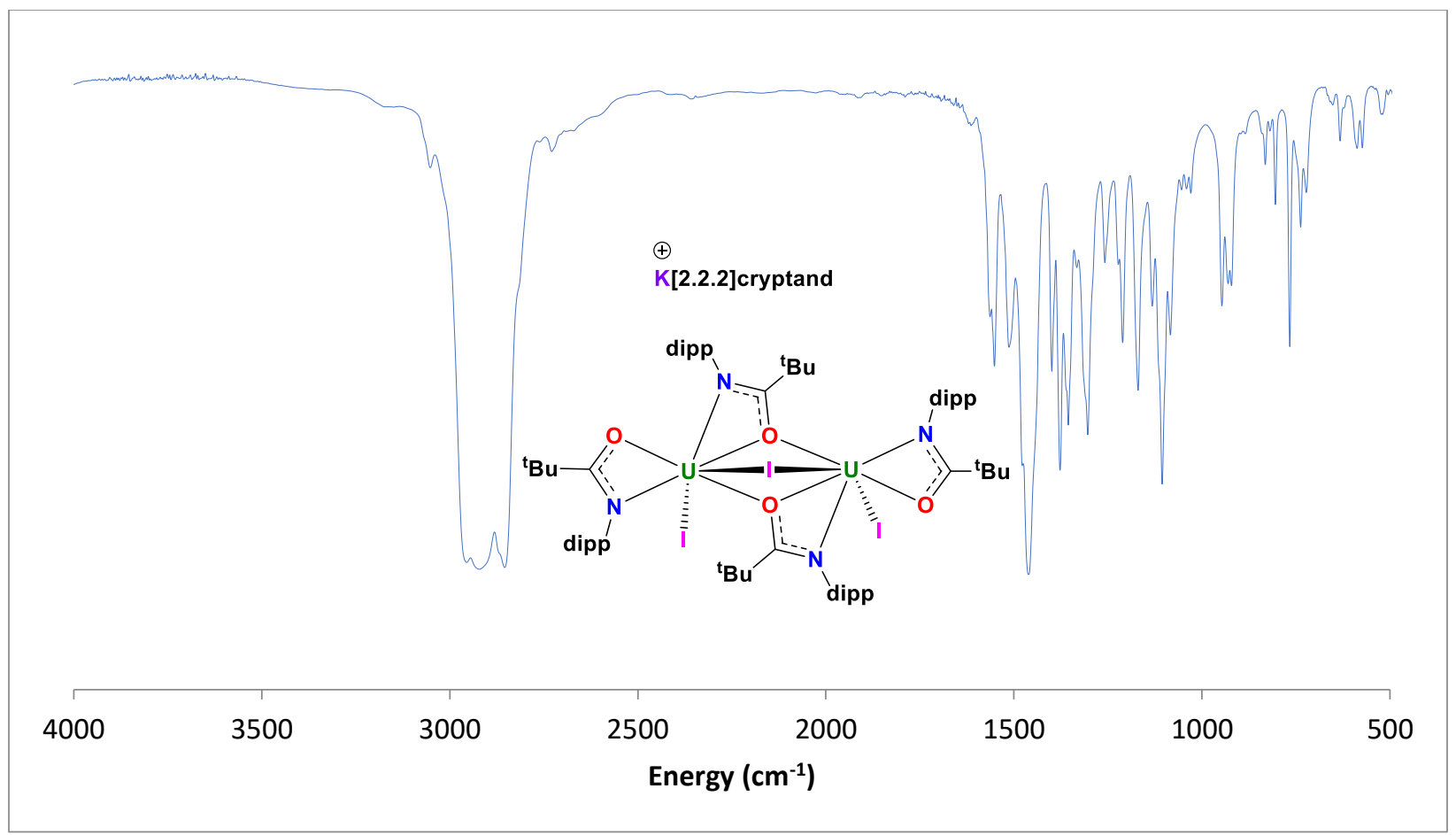

Figure S50. IR spectrum of [K[2.2.2] cryptand][(UI(TDA $\left.\left.)_{2}\right)_{2}(\mu-\mathrm{I})\right](6)$ prepared as a Nujol mull.

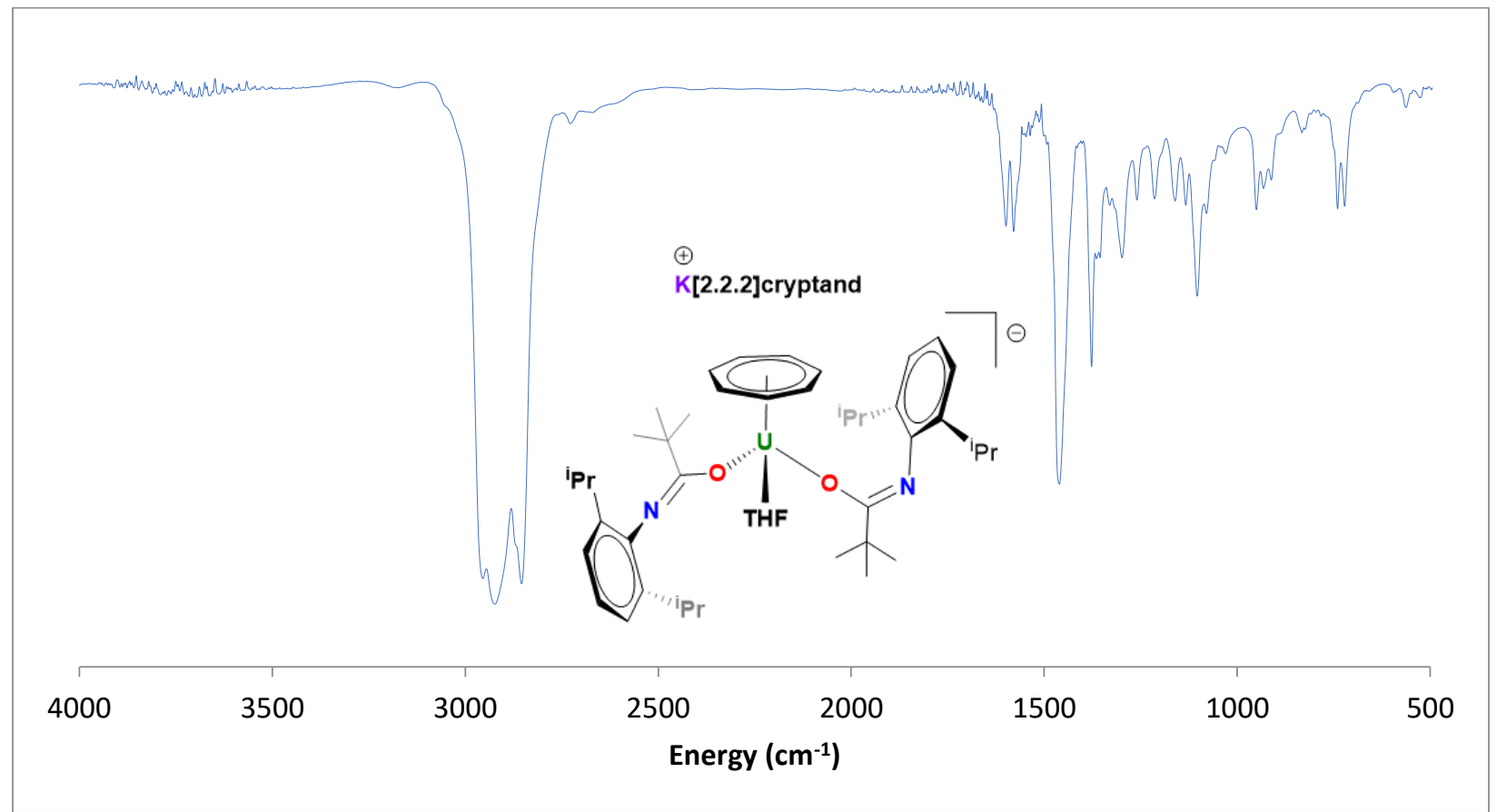

Figure S51. IR spectrum of $[\mathrm{K}[2.2 .2]$ cryptand $]\left[\mathrm{U}\left(\eta^{7}-\mathrm{C}_{7} \mathrm{H}_{7}\right)(\mathrm{TDA})_{2}(\mathrm{THF})\right]$ (7) prepared as a Nujol mull. 


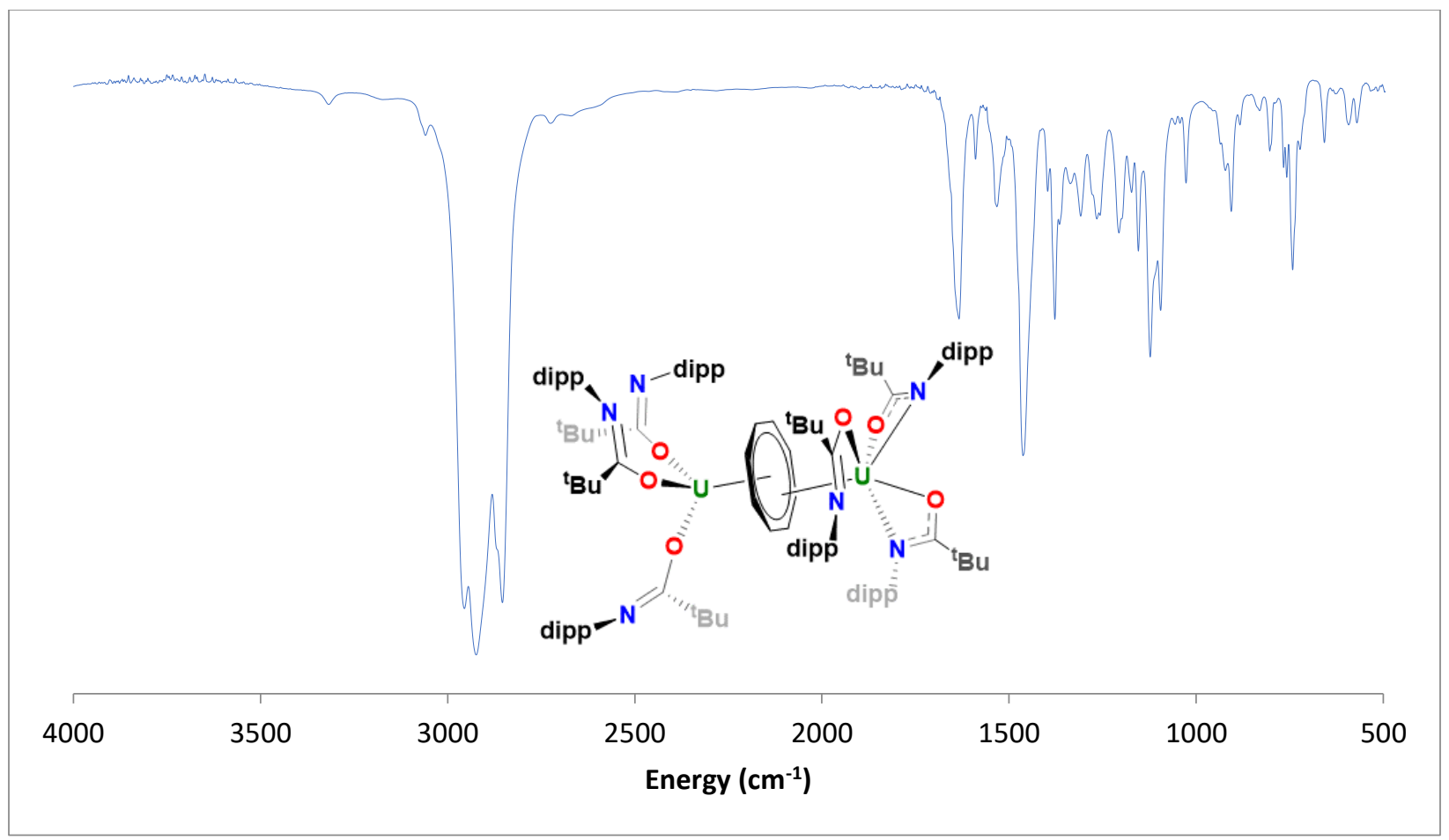

Figure S52. IR spectrum of $\left[\mathrm{U}(\mathrm{TDA})_{3}\right]_{2}\left(\mu-\eta^{8}: \eta^{3}-\mathrm{C}_{8} \mathrm{H}_{8}\right)(\mathbf{8})$ prepared as a Nujol mull.

\section{H. Calculations}

All DFT calculations were carried out with the Gaussian 09 suite of programs. ${ }^{10}$ Geometries were fully optimized in gas phase without symmetry constraints, employing the B3PW91 functional. ${ }^{11}$ The nature of the extrema was verified by analytical frequency calculations. Stuttgart effective core potentials ${ }^{12}$ and their associated basis set were used for silicon. Thorium and uranium atoms were treated with a small core effective core potential, associated with its adapted basis set. ${ }^{13}$ For the other elements $(\mathrm{C}, \mathrm{O}, \mathrm{N}$ and $\mathrm{H})$, Pople's double- $\zeta$ basis set 6-31G(d,p) was used. ${ }^{14}$ The electron density and partial charge distribution were examined in terms of localized electron-pair bonding units by using the NBO program. ${ }^{15}$ Through this method, the input atomic orbital basis set is transformed via natural atomic orbitals (NAOs) and natural hybrid orbitals (NHOs) into natural bond orbitals (NBOs), which correspond to the localized one center ("lone pair") and two-center ("bond") elements of the Lewis structure. All possible interactions between "filled" (donor) Lewis-type NBOs and "empty" (acceptor) non-Lewis NBOs orbitals, together with their energetic quantification (stabilization energy), were obtained 
by a second order perturbation theory analysis of the Fock matrix.

Natural electron configuration for 2:

$[\mathrm{Rn}] 7 \mathrm{~s}(0.13) 5 \mathrm{f}(3.23) 6 \mathrm{~d}(0.81) 7 \mathrm{p}(0.19) 8 \mathrm{~s}(0.01)$

Table S11: Calculated U-arene Second Order Donation and orbital contributions in 2.

\begin{tabular}{|c|c|c|}
\hline U-arene bond & $\begin{array}{r}\text { Second Order } \\
\text { Donation } \\
(\mathbf{k c a l} / \mathbf{m o l})\end{array}$ & Average orbital contributions from NBO \\
\hline U-(C8-C24-C53- & 39.6 & $\mathrm{U}=\mathrm{s}(1.28 \%) \mathrm{p}(4.00 \%) \mathrm{d}(26.50 \%) \mathrm{f}(65.58 \%)$ \\
$\mathrm{C} 61-\mathrm{C} 68-\mathrm{C} 79)$ & $\mathrm{C}=\mathrm{s}(1.06 \%) \mathrm{p}(98.12 \%)$ \\
\hline
\end{tabular}

Table S12: Wiberg bond indices for $\mathrm{U}-\mathrm{C}$ and $\mathrm{U}-\mathrm{O}$ bonds in 2 .

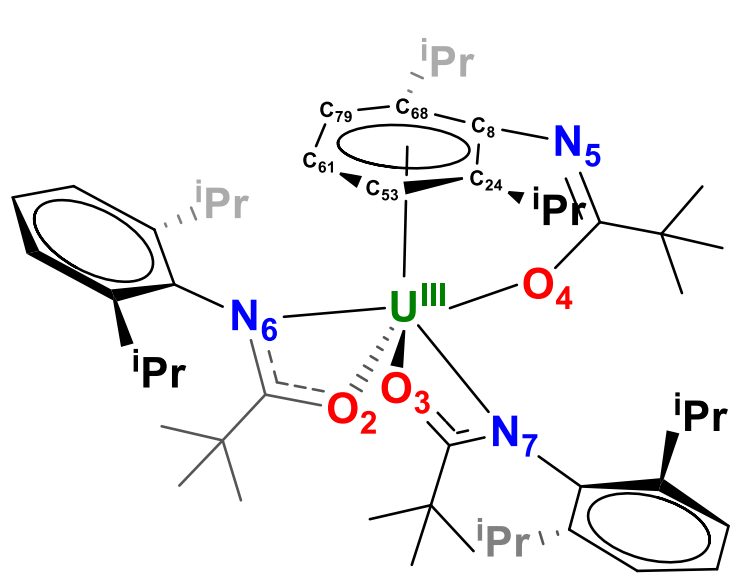

\begin{tabular}{|c|c|}
\hline Bond & $\begin{array}{c}\text { Wiberg Bond } \\
\text { Index }\end{array}$ \\
\hline U-O2 & 0.4529 \\
\hline U-O3 & 0.4479 \\
\hline U-O4 & 0.4788 \\
\hline U-N6 & 0.2781 \\
\hline U-N7 & 0.2693 \\
\hline U-C8 & 0.1264 \\
\hline U-C24 & 0.1172 \\
\hline U-C53 & 0.1147 \\
\hline U-C61 & 0.1277 \\
\hline U-C68 & 0.1180 \\
\hline U-C79 & 0.1134 \\
\hline
\end{tabular}


Table S13: Comparison of theoretical and experimental bond distances (in $\AA$ ) for 2 .

\begin{tabular}{|c|c|c|}
\hline Atoms & Theoretical & Experimental \\
\hline $\mathrm{U} 1-\mathrm{O} 1$ & 2.32085 & $2.310(2)$ \\
\hline $\mathrm{U} 1-\mathrm{O} 2$ & 2.33607 & $2.347(2)$ \\
\hline $\mathrm{U} 1-\mathrm{O} 3$ & 2.32339 & $2.334(2)$ \\
\hline $\mathrm{U} 1-\mathrm{N} 2$ & 2.64969 & $2.581(2)$ \\
\hline $\mathrm{U} 1-\mathrm{N} 3$ & 2.70256 & $2.652(2)$ \\
\hline $\mathrm{O} 2-\mathrm{C} 2-\mathrm{N} 2$ & 115.144 & $114.9(2)$ \\
\hline $\mathrm{O} 3-\mathrm{C} 3-\mathrm{N} 3$ & 115.507 & $115.3(2)$ \\
\hline $\mathrm{U} 1-\mathrm{C} 8$ & 2.86854 & $2.899(2)$ \\
\hline $\mathrm{U} 1-\mathrm{C} 9$ & 2.96305 & $2.965(2)$ \\
\hline $\mathrm{U} 1-\mathrm{C} 10$ & 2.98135 & $2.962(2)$ \\
\hline $\mathrm{U} 1-\mathrm{C} 11$ & 2.95859 & $2.939(2)$ \\
\hline $\mathrm{U} 1-\mathrm{C} 12$ & 2.98812 & $2.982(2)$ \\
\hline $\mathrm{U} 1-\mathrm{C} 13$ & 2.98392 & $2.988(2)$ \\
\hline
\end{tabular}

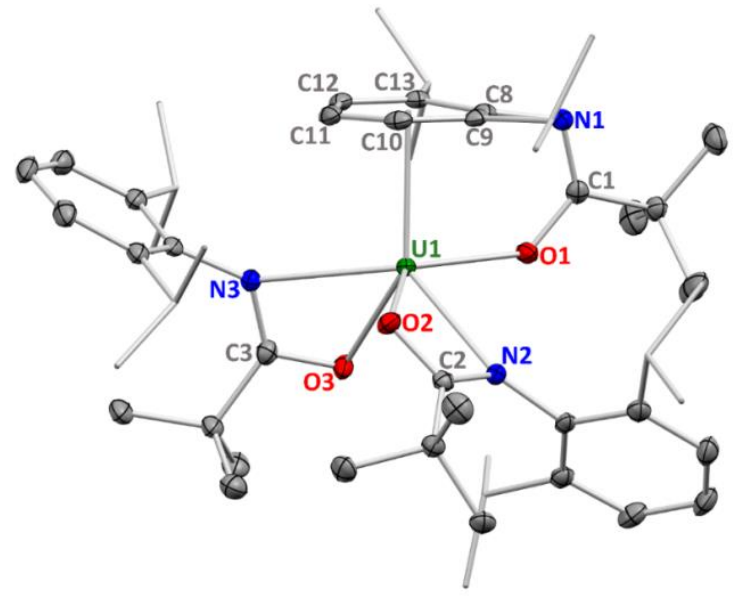

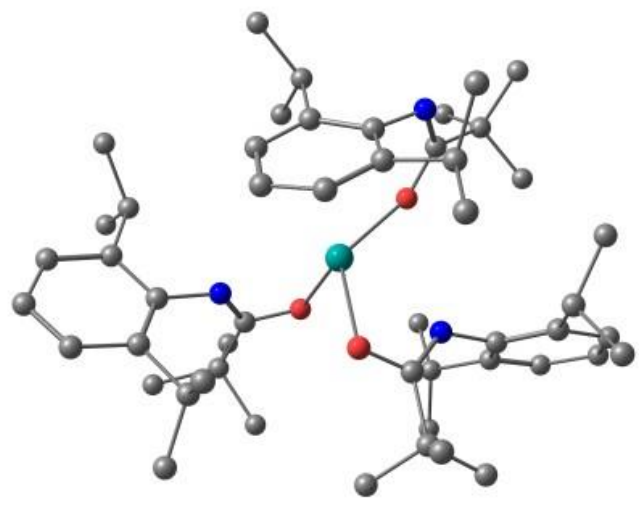

(a) $0.0 \mathrm{kcal} . \mathrm{mol}^{-1}$

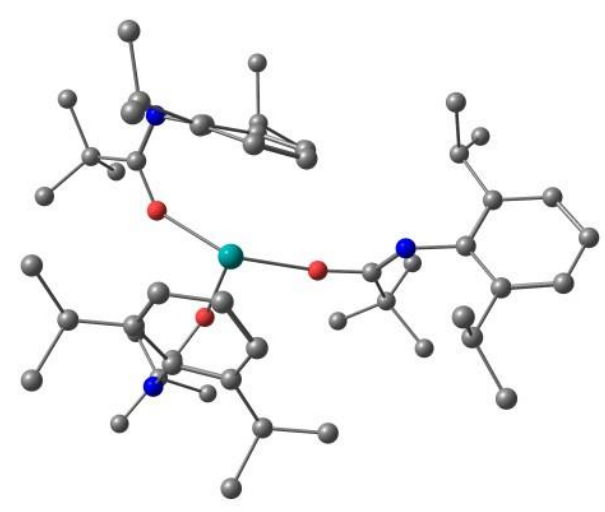

(b) $+7.5{\mathrm{kcal} . \mathrm{mol}^{-1}}^{-1}$

Figure S53 : Calculated enthalpy difference of 2 with one (a) or two (b) arene moieties bound. Hydrogen atoms are omitted for clarity. 

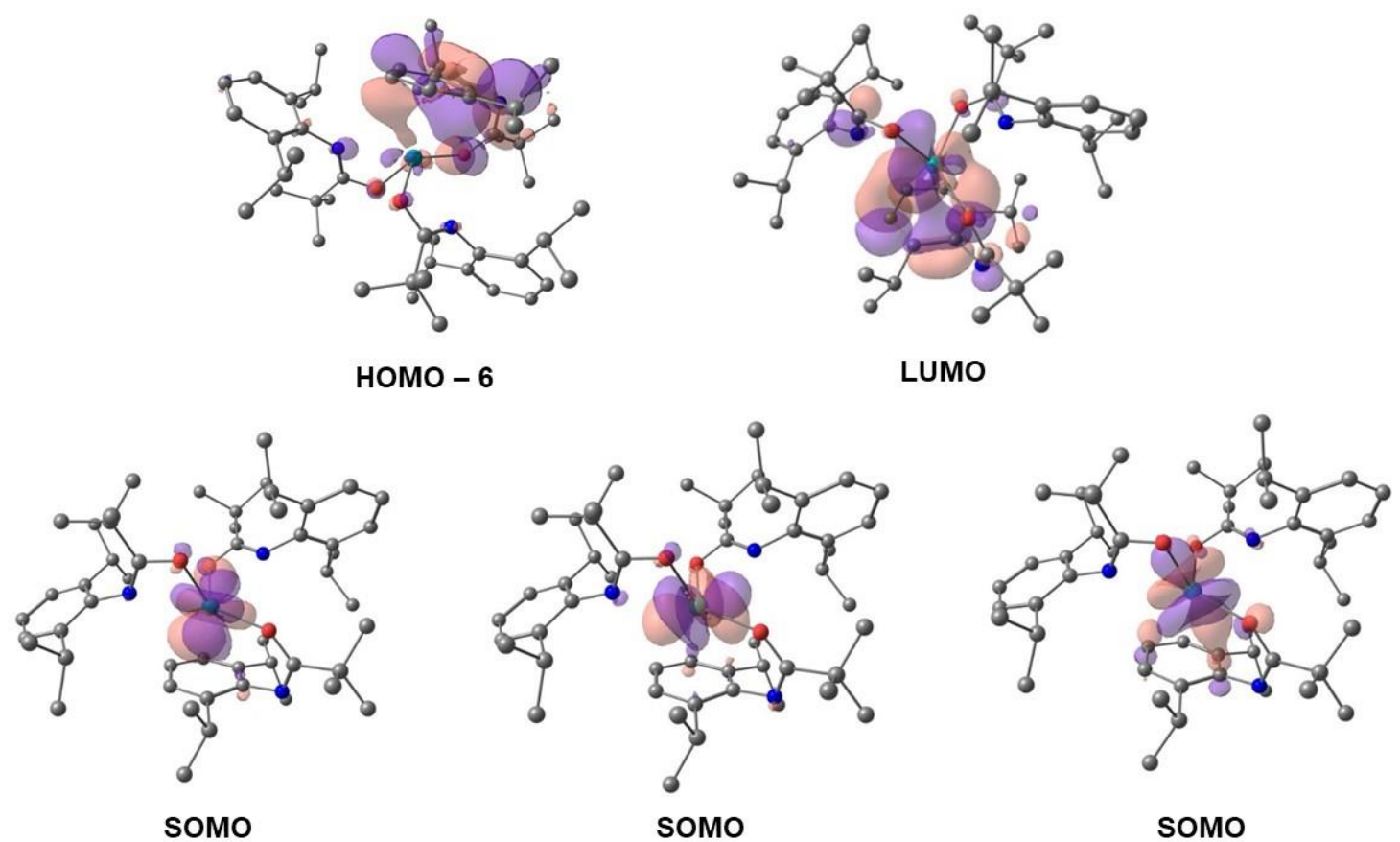

Figure S54: Selected molecular orbitals for the quartet ground state of 2 calculated using DFT. The three SOMO orbitals contain electrons primarily localized to nonbonding $5 \mathrm{f}_{\mathrm{z}}{ }^{3}$ (left), $5 \mathrm{f}_{\mathrm{x}}\left(\mathrm{y}^{2}-\right.$ $\left.\mathrm{z}^{2}\right)$ (center) and $5 \mathrm{f}_{\mathrm{y}}{ }^{3}$ (right) orbitals, while the HOMO- 6 and LUMO orbitals display $\delta$-bonding interactions between uranium $5 \mathrm{f}_{\mathrm{xyz}}$ and arene $\pi^{*}$ orbitals.

Natural electron configuration for $\mathbf{3}$ :

$[\mathrm{Rn}] 7 \mathrm{~s}(0.19) 5 \mathrm{f}(3.30) 6 \mathrm{~d}(1.43) 7 \mathrm{p}(0.30)$

Table S14: Calculated energies and spin densities for different oxidation states of $\mathbf{3}$.

\begin{tabular}{|c|c|c|c|}
\hline $\begin{array}{c}\text { Formal U } \\
\text { oxidation state }\end{array}$ & $\begin{array}{c}\text { Spin density } \\
\text { on U }\end{array}$ & $\begin{array}{c}\text { Energy } \\
\text { (Hartrees) }\end{array}$ & $\Delta \mathbf{E}$ (kcal/mol) \\
\hline IV & 2.5 & -2062.747612 & +20.7 \\
\hline III & 2.8 & -2062.780578 & 0.0 \\
\hline II & 3.4 & -2062.757079 & +14.7 \\
\hline I & 3.6 & -2062.773207 & +4.5 \\
\hline 0 & 3.8 & -2062.655465 & +88.8 \\
\hline
\end{tabular}


Table S15: Comparison of theoretical and experimental bond distances $(\AA)$ for 3 .

\begin{tabular}{|c|c|c|c|c|c|c|}
\hline Atoms & $\begin{array}{c}\text { Formal } \\
\text { U(IV) }\end{array}$ & $\begin{array}{c}\text { Formal } \\
\text { U(III) }\end{array}$ & $\begin{array}{c}\text { Formal } \\
\text { U(II) }\end{array}$ & $\begin{array}{c}\text { Formal } \\
\text { U(I) }\end{array}$ & $\begin{array}{c}\text { Formal } \\
\text { U(0) }\end{array}$ & Experimental \\
\hline $\mathrm{U} 1-\mathrm{O} 1$ & 2.27050 & 2.35757 & 2.50410 & 2.38107 & 2.50574 & $2.339(3)$ \\
\hline $\mathrm{U} 1-\mathrm{O} 2$ & 2.25366 & 2.39054 & 2.48411 & 2.38026 & 2.50597 & $2.356(4)$ \\
\hline $\mathrm{U} 1-\mathrm{N} 1$ & 3.56280 & 3.54103 & 3.60501 & 3.54372 & 3.57591 & $3.548(4)$ \\
\hline $\mathrm{U} 1-\mathrm{N} 2$ & 3.51724 & 3.59608 & 3.58384 & 3.54234 & 3.57843 & $3.579(4)$ \\
\hline $\mathrm{O} 1-\mathrm{C} 7-\mathrm{N} 1$ & 122.813 & 124.478 & 126.506 & 124.838 & 126.615 & $123.5(4)$ \\
\hline $\mathrm{O} 2-\mathrm{C} 24-\mathrm{N} 2$ & 122.805 & 124.376 & 126.511 & 124.788 & 126.575 & $124.1(5)$ \\
\hline $\mathrm{U} 1-\mathrm{C} 1$ & 2.76190 & 2.67306 & 2.70123 & 2.70414 & 2.69635 & $2.689(6)$ \\
\hline $\mathrm{U} 1-\mathrm{C} 2$ & 2.91506 & 2.60336 & 2.57706 & 2.74560 & 2.72180 & $2.595(6)$ \\
\hline $\mathrm{U} 1-\mathrm{C} 3$ & 2.82255 & 2.73824 & 2.70617 & 2.74144 & 2.71450 & $2.741(5)$ \\
\hline $\mathrm{U} 1-\mathrm{C} 4$ & 2.70296 & 2.69878 & 2.69999 & 2.70991 & 2.72985 & $2.714(4)$ \\
\hline $\mathrm{U} 1-\mathrm{C} 5$ & 2.76195 & 2.57916 & 2.58734 & 2.73811 & 2.74146 & $2.604(5)$ \\
\hline $\mathrm{U} 1-\mathrm{C} 6$ & 2.77039 & 2.73521 & 2.75983 & 2.76432 & 2.73941 & $2.745(6)$ \\
\hline $\mathrm{U} 1-\mathrm{C} 18$ & 2.70063 & 2.74971 & 2.71085 & 2.70414 & 2.69721 & $2.720(6)$ \\
\hline $\mathrm{U} 1-\mathrm{C} 19$ & 2.76000 & 2.76929 & 2.72390 & 2.76953 & 2.72279 & $2.728(5)$ \\
\hline $\mathrm{U} 1-\mathrm{C} 20$ & 2.70891 & 2.71981 & 2.70318 & 2.74300 & 2.71138 & $2.706(6)$ \\
\hline $\mathrm{U} 1-\mathrm{C} 21$ & 2.62482 & 2.74868 & 2.71326 & 2.71493 & 2.72074 & $2.751(6)$ \\
\hline $\mathrm{U} 1-\mathrm{C} 22$ & 2.81545 & 2.77408 & 2.71727 & 2.74627 & 2.73300 & $2.763(6)$ \\
\hline $\mathrm{U} 1-\mathrm{C} 23$ & 2.87967 & 2.76400 & 2.72230 & 2.74927 & 2.73797 & $2.716(5)$ \\
\hline
\end{tabular}


Table S16: Calculated U-arene second order donation and orbital contributions in 3.

\begin{tabular}{|c|c|c|}
\hline U-arene bond & $\begin{array}{c}\text { Second Order } \\
\text { Donation } \\
\text { (kcal/mol) }\end{array}$ & Average orbital contributions from NBO \\
\hline $\begin{array}{c}\text { U-(C1-C2-C3-C4- } \\
\text { C5-C6) }\end{array}$ & 53 & $\mathrm{U}=\mathrm{s}(4.46 \%) \mathrm{p}(5.92 \%) \mathrm{d}(57.26 \%) \mathrm{f}(32.36 \%)$ \\
$\mathrm{C}=\mathrm{s}(8.29 \%) \mathrm{p}(91.69 \%)$
\end{tabular}

Table S17: Wiberg bond indices for $\mathrm{U}-\mathrm{C}$ and $\mathrm{U}-\mathrm{O}$ bonds in 3 .

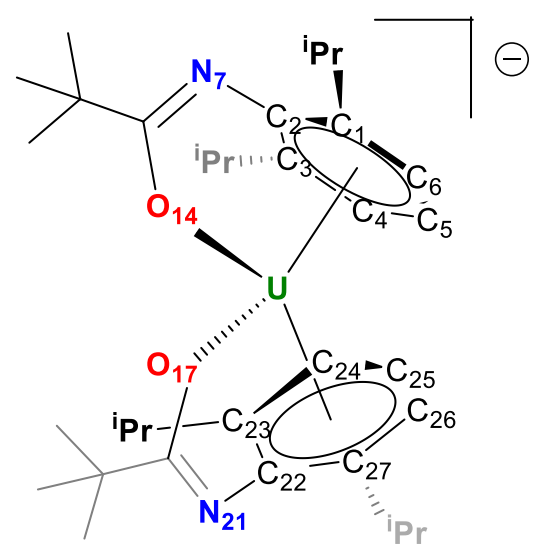

\begin{tabular}{|c|c|}
\hline Bond & $\begin{array}{c}\text { Wiberg Bond } \\
\text { Index }\end{array}$ \\
\hline U-O14 & 0.6104 \\
\hline U-O17 & 0.5817 \\
\hline U-C1 & 0.4564 \\
\hline U-C2 & 0.2394 \\
\hline U-C3 & 0.2300 \\
\hline U-C4 & 0.4984 \\
\hline U-C5 & 0.2667 \\
\hline U-C6 & 0.2233 \\
\hline U-C22 & 0.1954 \\
\hline U-C23 & 0.2250 \\
\hline U-C24 & 0.2899 \\
\hline U-C25 & 0.2244 \\
\hline U-C26 & 0.2215 \\
\hline U-C27 & 0.2656 \\
\hline
\end{tabular}


Natural electron configuration for 5 :

Th1: [Rn]7s(0.13)5f(0.68)6d(1.26)7p(0.18)

Table S18: Calculated energies and spin densities for different oxidation states of 5.

\begin{tabular}{|c|c|c|c|}
\hline $\begin{array}{c}\text { Formal Th } \\
\text { oxidation state }\end{array}$ & $\begin{array}{c}\text { Spin density } \\
\text { on Th }\end{array}$ & $\begin{array}{c}\text { Enthalpy } \\
\text { (Hartrees) }\end{array}$ & $\Delta \mathbf{H}(\mathrm{kcal} / \mathbf{m o l})$ \\
\hline IV & 0 (singlet) & -3018.632851 & 0 \\
\hline III & 0.91 & -3018.619047 & +8.7 \\
\hline
\end{tabular}

Table S19: Calculated U-arene second order donation and orbital contributions in 5.

\begin{tabular}{|c|c|c|}
\hline Th-arene bond & $\begin{array}{c}\text { Second Order } \\
\text { Donation } \\
(\mathbf{k c a l} / \mathbf{m o l})\end{array}$ & Average orbital contributions from NBO \\
\hline Th-(C8-C9-C10- & 92 & $\begin{array}{l}\mathrm{Th}=\mathrm{s}(0.02 \%) \mathrm{p}(0.52 \%) \mathrm{d}(94.19 \%) \mathrm{f}(5.25 \%) \\
\mathrm{C}=\mathrm{s}(36.67 \%) \mathrm{p}(63.28 \%)\end{array}$ \\
$\mathrm{C} 11-\mathrm{C} 12-\mathrm{C} 13)$ & &
\end{tabular}

Table S20: Wiberg bond indices for $\mathrm{U}-\mathrm{C}$ and $\mathrm{U}-\mathrm{O}$ bonds in $\mathbf{5}$.

\begin{tabular}{|c|c|}
\hline Bond & $\begin{array}{c}\text { Wiberg Bond } \\
\text { Index }\end{array}$ \\
\hline Th-O1 & 0.4649 \\
\hline Th-O2 & 0.5286 \\
\hline Th-O3 & 0.5462 \\
\hline Th-O4 & 0.2467 \\
\hline Th-C8 & 0.2398 \\
\hline Th-C9 & 0.4841 \\
\hline Th-C10 & 0.1838 \\
\hline Th-C11 & 0.2404 \\
\hline Th-C12 & 0.4937 \\
\hline Th-C13 & 0.1700 \\
\hline Th-C1 & 0.0323 \\
\hline Th-N1 & 0.0657 \\
\hline
\end{tabular}

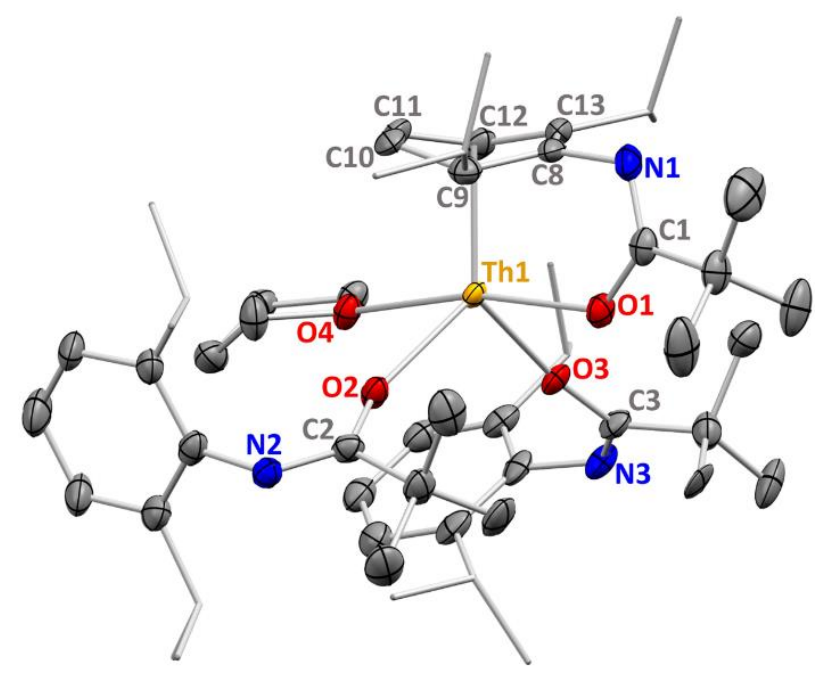


Table S21: Comparison of theoretical and experimental bond distances $(\AA)$ for 5 .

\begin{tabular}{|c|c|c|c|}
\hline Bond & Th(IV) & Th(III) & Experimental \\
\hline Th1 - O1 & 2.418 & 2.386 & $2.400(5)$ \\
\hline Th1 - O2 & 2.368 & 2.374 & $2.332(4)$ \\
\hline Th1 - O3 & 2.357 & 2.359 & $2.316(3)$ \\
\hline Th1 - O4 & 2.655 & 2.659 & $2.586(5)$ \\
\hline Th1 - C8 & 2.658 & 2.684 & $2.674(5)$ \\
\hline Th1 - C9 & 2.544 & 2.760 & $2.549(5)$ \\
\hline Th1 - C10 & 2.795 & 2.750 & $2.783(5)$ \\
\hline Th1 - C11 & 2.770 & 2.745 & $2.742(6)$ \\
\hline Th1 - C12 & 2.577 & 2.731 & $2.556(6)$ \\
\hline Th1 - C13 & 2.784 & 2.731 & $2.794(5)$ \\
\hline C8 - C9 & 1.516 & 1.429 & $1.513(9)$ \\
\hline C9 - C10 & 1.451 & 1.427 & $1.47(1)$ \\
\hline C10 - C11 & 1.372 & 1.418 & $1.358(9)$ \\
\hline C11 - C12 & 1.468 & 1.419 & $1.458(8)$ \\
\hline C12 - C13 & 1.460 & 1.429 & $1.47(1)$ \\
\hline C13 - C8 & 1.382 & 1.437 & $1.374(9)$ \\
\hline
\end{tabular}

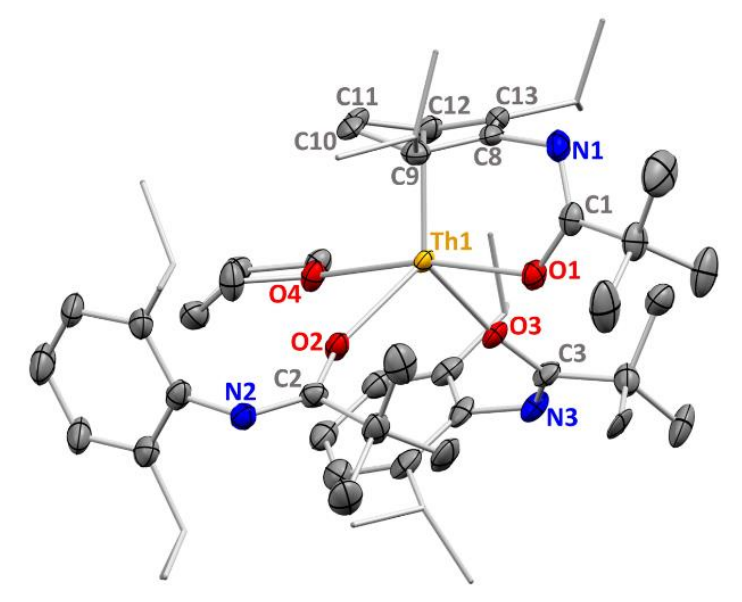




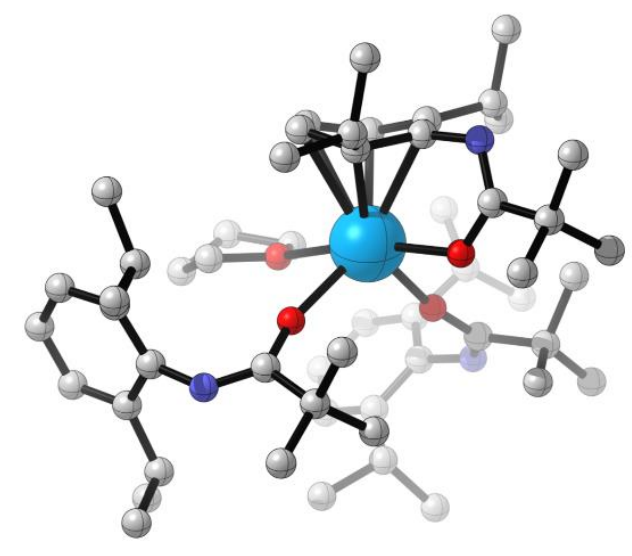

(a) $0.0 \mathrm{kcal} . \mathrm{mol}^{-1}$

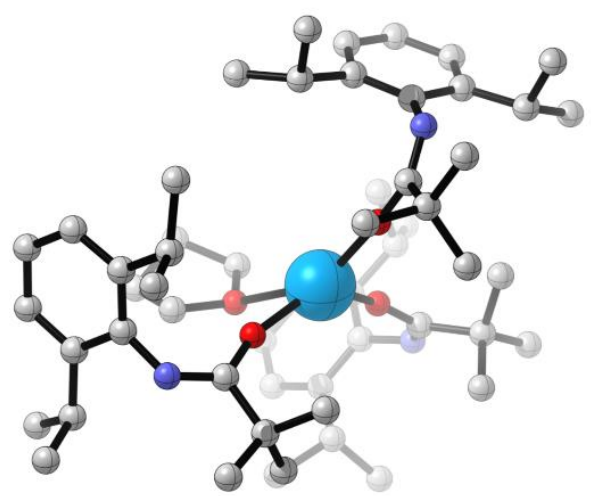

(b) $+28.4 \mathrm{kcal}_{\mathrm{mol}}{ }^{-1}$

Figure S55: Calculated enthalpy difference of Complex 5 with bound (a) and unbound (b) arene moieties. Hydrogen atoms are omitted for clarity.

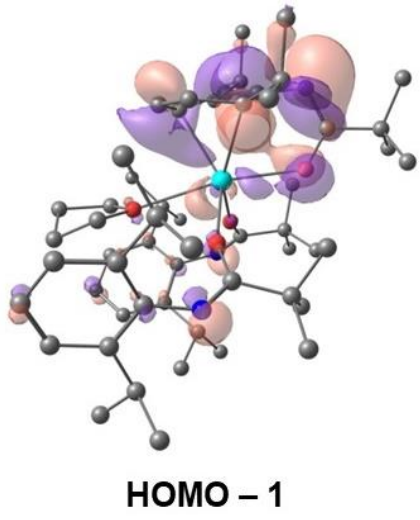

HOMO - 1
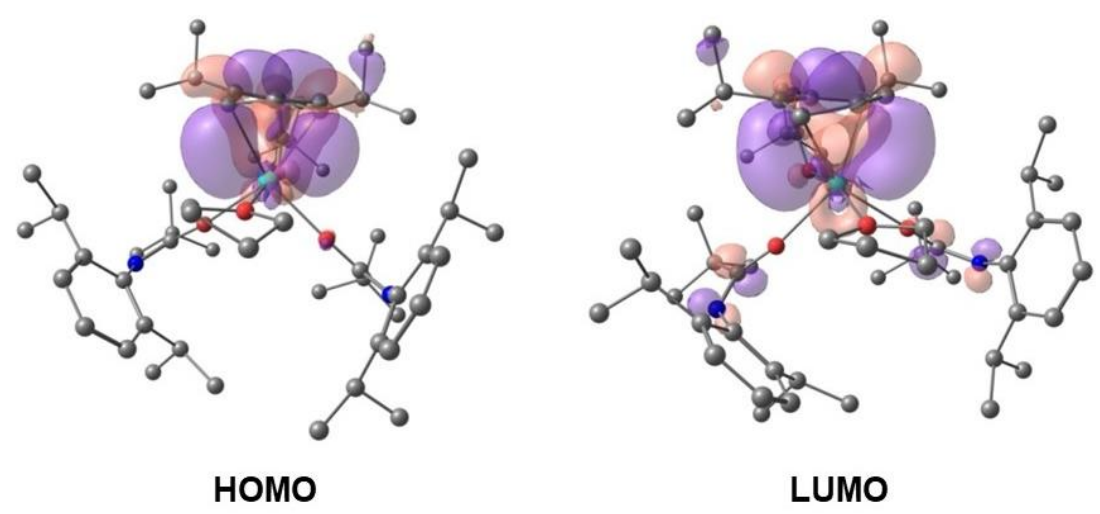

Figure S56. Selected molecular orbitals calculated using DFT for the singlet spin state of $\mathbf{5}$. The HOMO-1 is primarily of Th $6 \mathrm{~d}_{z}^{2}$ character. The HOMO displays $\delta$-bonding interactions between the Th $5 \mathrm{f}_{\mathrm{x}\left(\mathrm{x}^{2}-3 \mathrm{y}^{2}\right)}{ }^{2} / 6 \mathrm{~d}_{\left(\mathrm{x}^{2}-\mathrm{y}^{2}\right)}$ orbitals and the arene $\pi^{*}$ orbitals, while the LUMO displays $\delta$ -

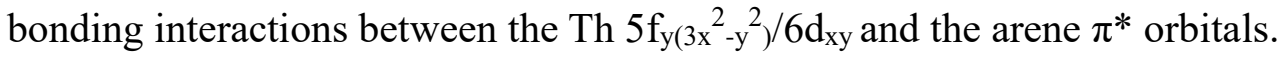


Natural electron configuration for 7:

U1: [Rn]7s(0.13)5f(3.09)6d(1.38)7p(0.21)

Table S22: Calculated energies and spin densities for different oxidation states of 7.

\begin{tabular}{|c|c|c|c|}
\hline $\begin{array}{c}\text { Formal U } \\
\text { oxidation state }\end{array}$ & $\begin{array}{c}\text { Spin density on } \\
\mathbf{U}\end{array}$ & Energy (Hartrees) & $\Delta \mathbf{E ~ ( k c a l / m o l )}$ \\
\hline VI & - & -2566.845253 & +26.5 \\
\hline IV & +2.3 & -2566.887426 & 0.0 \\
\hline II & +3.3 & -2566.848341 & +24.5 \\
\hline
\end{tabular}


Table S23: Comparison of theoretical and experimental bond distances (in $\AA$ ) for 7 .

\begin{tabular}{|c|c|c|}
\hline Atoms & Theoretical & Experimental \\
\hline $\mathrm{U} 1-\mathrm{O} 1$ & 2.29309 & $2.255(2)$ \\
\hline $\mathrm{U} 1-\mathrm{O} 2$ & 2.31408 & $2.272(2)$ \\
\hline $\mathrm{U} 1-\mathrm{O} 3$ & 2.66122 & $2.569(2)$ \\
\hline $\mathrm{U} 1-\mathrm{C} 3$ & 2.54645 & $2.571(5)$ \\
\hline $\mathrm{U} 1-\mathrm{C} 4$ & 2.54270 & $2.563(4)$ \\
\hline $\mathrm{U} 1-\mathrm{C} 5$ & 2.55943 & $2.567(4)$ \\
\hline $\mathrm{U} 1-\mathrm{C} 6$ & 2.58061 & $2.577(4)$ \\
\hline $\mathrm{U} 1-\mathrm{C} 7$ & 2.57627 & $2.568(5)$ \\
\hline $\mathrm{U} 1-\mathrm{C} 8$ & 2.57416 & $2.576(4)$ \\
\hline $\mathrm{U} 1-\mathrm{C} 9$ & 2.56340 & $2.572(3)$ \\
\hline
\end{tabular}

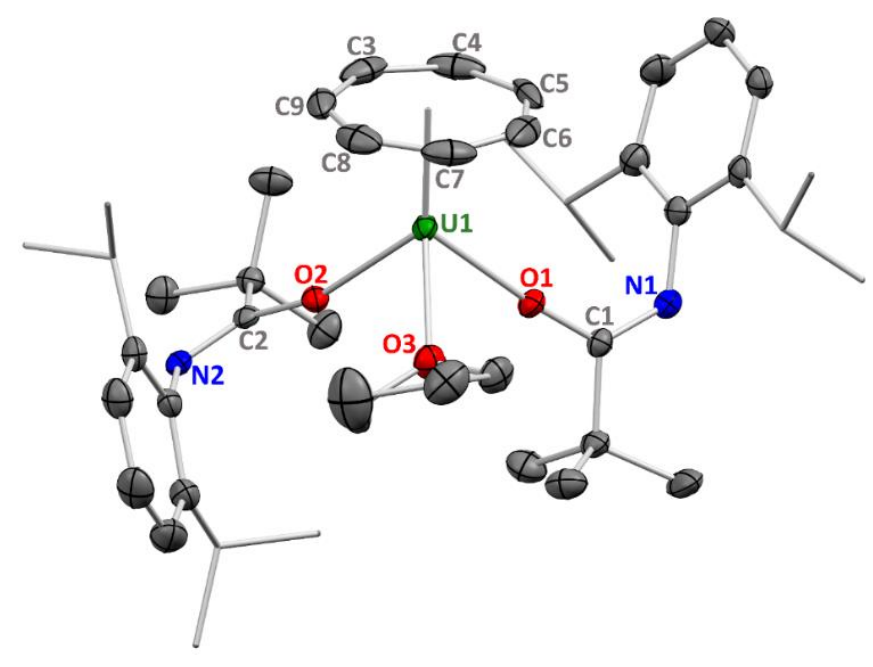

Table S24: Calculated $\mathrm{U}-\mathrm{C}_{7} \mathrm{H}_{7}$ Second Order Donation and orbital contributions in 7.

\begin{tabular}{|c|c|c|}
\hline U-C $\mathbf{C}_{7} \mathrm{H}_{7}$ bond & $\begin{array}{c}\text { Second Order } \\
\text { Donation } \\
\text { (kcal/mol })\end{array}$ & Average orbital contributions from NBO \\
\hline $\begin{array}{c}\text { From } \mathrm{U} \text { to } \pi^{*}(\mathrm{C} 43- \\
\text { C44-C45-C46-C47- } \\
\mathrm{C} 48)\end{array}$ & 89 & \multirow{2}{*}{$\mathrm{U}=\mathrm{s}(2.21 \%) \mathrm{p}(4.66 \%) \mathrm{d}(48.97 \%) \mathrm{f}(44.16 \%)$} \\
\cline { 1 - 1 } From $\sigma\left(\mathrm{C}_{7} \mathrm{H}_{7}\right)$ to $\mathrm{U}$ & 307.6 & $\mathrm{C}=\mathrm{s}(19.17 \%) \mathrm{p}(80.83 \%)$ \\
\hline From $\pi\left(\mathrm{C}_{7} \mathrm{H}_{7}\right)$ to $\mathrm{U}$ & 230.0 & \\
\hline
\end{tabular}



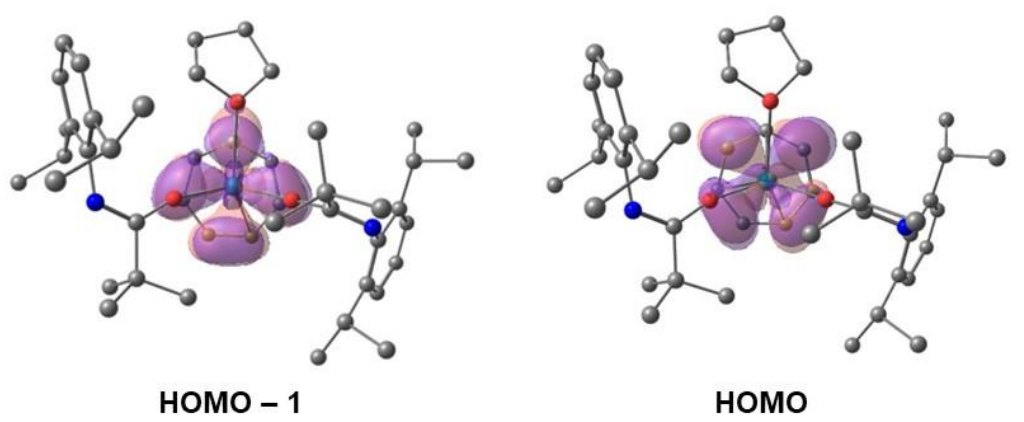

HOMO
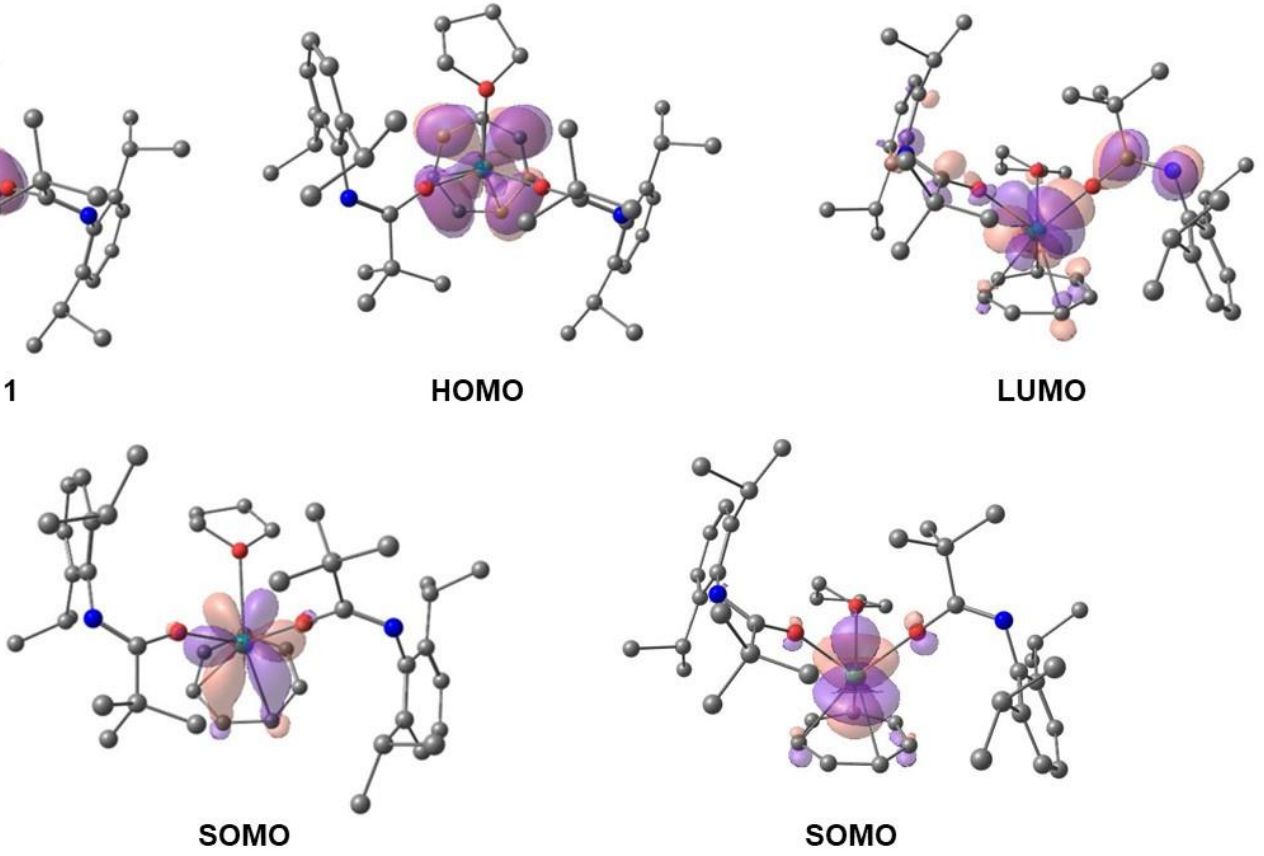

Figure S57: Selected molecular orbitals for the ground state of 7 calculated using DFT. The two SOMOs contain electrons primarily localized to $5 \mathrm{f}_{\mathrm{x}}{ }^{3}$ (right) and $5 \mathrm{f}_{\mathrm{x}\left(\mathrm{x}^{2}-3 \mathrm{y}^{2}\right)}$ orbitals (left), while the HOMO-1 and HOMO display $\delta$-bonding interactions between the uranium $5 \mathrm{f}_{\mathrm{z}\left(\mathrm{x}^{2}-\mathrm{y}^{2}\right)}$ and $5 f_{y\left(3 x^{2}-y^{2}\right)}$ orbitals, respectively, and the cycloheptatrienyl $\pi^{*}$ orbitals. The LUMO is mainly of $5 \mathrm{f}_{\mathrm{xyz}}$ character. 
Table S25: Wiberg bond indices for $\mathrm{U}-\mathrm{C}$ and $\mathrm{U}-\mathrm{O}$ bonds in 7 .

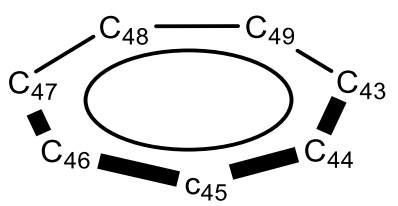

\begin{tabular}{|c|c|}
\hline Bond & $\begin{array}{c}\text { Wiberg Bond } \\
\text { Index }\end{array}$ \\
\hline U-C43 & 0.4153 \\
\hline U-C44 & 0.4077 \\
\hline U-C45 & 0.4158 \\
\hline U-C46 & 0.4066 \\
\hline U-C47 & 0.4117 \\
\hline U-C48 & 0.4197 \\
\hline U-C49 & 0.4218 \\
\hline
\end{tabular}

Natural electron configuration for $\mathbf{8}$ :

$\mathrm{U} 1:[\mathrm{Rn}] 7 \mathrm{~s}(0.06) 5 \mathrm{f}(2.92) 6 \mathrm{~d}(1.13) 7 \mathrm{p}(0.19)$

$\mathrm{U} 2:[\mathrm{Rn}] 7 \mathrm{~s}(0.06) 5 \mathrm{f}(2.74) 6 \mathrm{~d}(0.93) 7 \mathrm{p}(0.18) 8 \mathrm{~s}(0.01)$ 
Table S26: Comparison of theoretical and experimental bond distances ( $\AA$ ) for $\mathbf{8}$.

\begin{tabular}{|c|c|c|}
\hline Atoms & Theoretical & Experimental \\
\hline $\mathrm{U} 1-\mathrm{O} 1$ & 2.24958 & $2.268(2)$ \\
\hline $\mathrm{U} 1-\mathrm{O} 2$ & 2.26573 & $2.259(2)$ \\
\hline $\mathrm{U} 1-\mathrm{O} 3$ & 2.11503 & $2.105(2)$ \\
\hline $\mathrm{U} 1-\mathrm{N} 1$ & 2.51832 & $2.480(2)$ \\
\hline $\mathrm{U} 1-\mathrm{N} 2$ & 2.54030 & $2.488(2)$ \\
\hline $\mathrm{O} 1-\mathrm{C} 9-\mathrm{N} 1$ & 114.167 & $113.8(2)$ \\
\hline $\mathrm{O} 2-\mathrm{C} 26-\mathrm{N} 2$ & 113.845 & $113.7(2)$ \\
\hline $\mathrm{U} 1-\mathrm{C} 1$ & 2.93415 & $2.839(3)$ \\
\hline $\mathrm{U} 1-\mathrm{C} 2$ & 2.72663 & $2.708(3)$ \\
\hline $\mathrm{U} 1-\mathrm{C} 3$ & 2.98589 & $2.954(3)$ \\
\hline $\mathrm{U} 1-\mathrm{C} 4$ & 3.56353 & $3.540(3)$ \\
\hline $\mathrm{U} 1-\mathrm{C} 5$ & 4.11587 & $4.027(3)$ \\
\hline $\mathrm{U} 1-\mathrm{C} 6$ & 4.34333 & $4.101(3)$ \\
\hline $\mathrm{U} 1-\mathrm{C} 7$ & 4.12544 & $3.762(4)$ \\
\hline $\mathrm{U} 1-\mathrm{C} 8$ & 3.56304 & $3.232(4)$ \\
\hline $\mathrm{U} 2-\mathrm{O} 4$ & 2.12203 & $2.131(2)$ \\
\hline $\mathrm{U} 2-\mathrm{O} 5$ & 2.19680 & $2.171(2)$ \\
\hline $\mathrm{U} 2-\mathrm{O} 6$ & 2.15221 & $2.148(2)$ \\
\hline $\mathrm{U} 2-\mathrm{C} 1$ & 2.72970 & $2.759(3)$ \\
\hline $\mathrm{U} 2-\mathrm{C} 2$ & 2.75822 & $2.760(3)$ \\
\hline $\mathrm{U} 2-\mathrm{C} 3$ & 2.85220 & $2.824(3)$ \\
\hline $\mathrm{U} 2-\mathrm{C} 4$ & 2.93647 & $2.810(3)$ \\
\hline $\mathrm{U} 2-\mathrm{C} 5$ & 2.90384 & $2.753(3)$ \\
\hline $\mathrm{U} 2-\mathrm{C} 6$ & 2.88969 & $2.744(3)$ \\
\hline $\mathrm{U} 2-\mathrm{C} 7$ & 2.85397 & $2.789(3)$ \\
\hline $\mathrm{U} 2-\mathrm{C} 8$ & 2.77871 & $2.816(3)$ \\
\hline & & \\
\hline
\end{tabular}

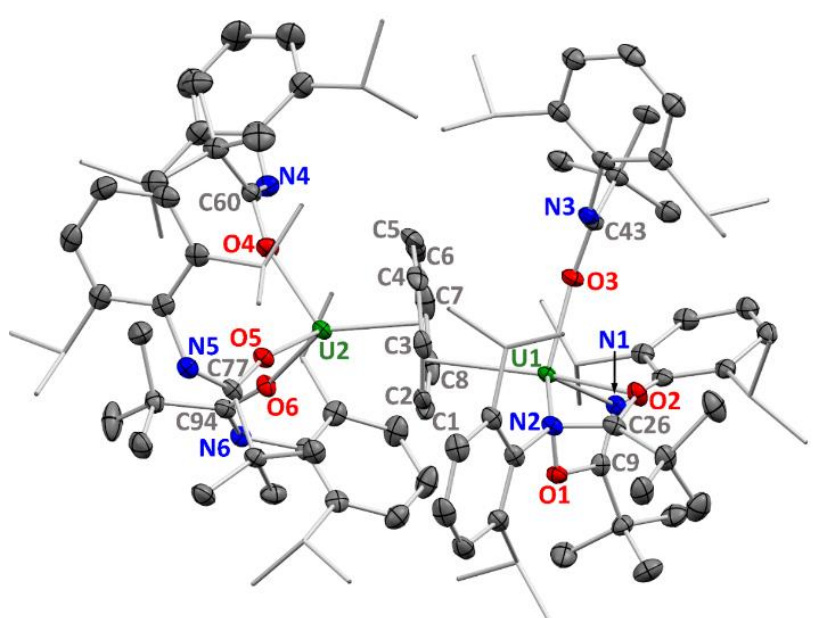


Table S27: Calculated $\mathrm{U}-\mathrm{C}_{8} \mathrm{H}_{8}$ Second Order Donation and orbital contributions in 8 .

\begin{tabular}{|c|c|c|}
\hline $\mathrm{U}-\mathrm{C}_{8} \mathrm{H}_{8}$ bond & $\begin{array}{c}\text { Second Order } \\
\text { Donation } \\
(\text { kcal/mol })\end{array}$ & $\begin{array}{c}\text { Average orbital contributions } \\
\text { from NBO }\end{array}$ \\
\hline $\begin{array}{l}\text { From } \sigma(\mathrm{C} 107-\mathrm{C} 116-\mathrm{C} 117-\mathrm{C} 118- \\
\mathrm{C} 120-\mathrm{C} 122-\mathrm{C} 123-\mathrm{C} 124) \text { to U1 }\end{array}$ & 241.9 & \multirow{2}{*}{$\begin{array}{c}\mathrm{U}=\mathrm{s}(2.92 \%) \mathrm{p}(3.19 \%) \mathrm{d}(33.32 \%) \\
\mathrm{f}(60.57 \%) \\
\mathrm{C}=\mathrm{s}(16.65 \%) \mathrm{p}(83.35 \%)\end{array}$} \\
\hline $\begin{array}{c}\text { From } \pi(\mathrm{C} 107-\mathrm{C} 116-\mathrm{C} 117-\mathrm{C} 118- \\
\mathrm{C} 120-\mathrm{C} 122-\mathrm{C} 123-\mathrm{C} 124) \text { to U1 }\end{array}$ & 118.4 & \\
\hline $\begin{array}{c}\text { From } \sigma(\mathrm{C} 107-\mathrm{C} 116-\mathrm{C} 117-\mathrm{C} 118- \\
\mathrm{C} 120-\mathrm{C} 122-\mathrm{C} 123-\mathrm{C} 124) \text { to U2 }\end{array}$ & 91.8 & \multirow{2}{*}{$\begin{array}{c}\mathrm{U}=\mathrm{s}(2.96 \%) \mathrm{p}(3.58 \%) \mathrm{d}(29.18 \%) \\
\mathrm{f}(64.28 \%) \\
\mathrm{C}=\mathrm{s}(29.26 \%) \mathrm{p}(70.74 \%)\end{array}$} \\
\hline $\begin{array}{l}\text { From } \pi(\mathrm{C} 107-\mathrm{C} 116-\mathrm{C} 117-\mathrm{C} 118- \\
\mathrm{C} 120-\mathrm{C} 122-\mathrm{C} 123-\mathrm{C} 124) \text { to U2 }\end{array}$ & 55.3 & \\
\hline
\end{tabular}

Table S28: Wiberg bond indices for U-C bonds in $\mathbf{8}$.

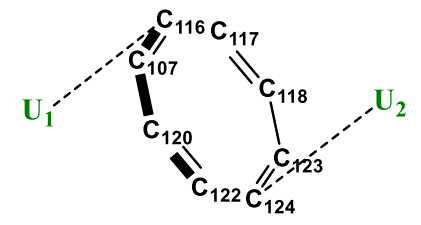

\begin{tabular}{|c|c|}
\hline Bond & $\begin{array}{c}\text { Wiberg Bond } \\
\text { Index }\end{array}$ \\
\hline $\mathrm{U} 1-\mathrm{C} 107$ & 0.2306 \\
\hline $\mathrm{U} 1-\mathrm{C} 116$ & 0.2352 \\
\hline $\mathrm{U} 1-\mathrm{C} 117$ & 0.2091 \\
\hline $\mathrm{U} 1-\mathrm{C} 118$ & 0.1936 \\
\hline $\mathrm{U} 1-\mathrm{C} 120$ & 0.2052 \\
\hline $\mathrm{U} 1-\mathrm{C} 122$ & 0.1600 \\
\hline $\mathrm{U} 1-\mathrm{C} 123$ & 0.1760 \\
\hline $\mathrm{U} 1-\mathrm{C} 124$ & 0.1725 \\
\hline
\end{tabular}

\begin{tabular}{|c|c|}
\hline Bond & $\begin{array}{c}\text { Wiberg Bond } \\
\text { Index }\end{array}$ \\
\hline $\mathrm{U} 2-\mathrm{C} 107$ & 0.0296 \\
\hline $\mathrm{U} 2-\mathrm{C} 116$ & 0.0212 \\
\hline $\mathrm{U} 2-\mathrm{C} 117$ & 0.0311 \\
\hline $\mathrm{U} 2-\mathrm{C} 118$ & 0.0641 \\
\hline $\mathrm{U} 2-\mathrm{C} 120$ & 0.0598 \\
\hline $\mathrm{U} 2-\mathrm{C} 122$ & 0.1508 \\
\hline $\mathrm{U} 2-\mathrm{C} 123$ & 0.1358 \\
\hline $\mathrm{U} 2-\mathrm{C} 124$ & 0.1832 \\
\hline
\end{tabular}




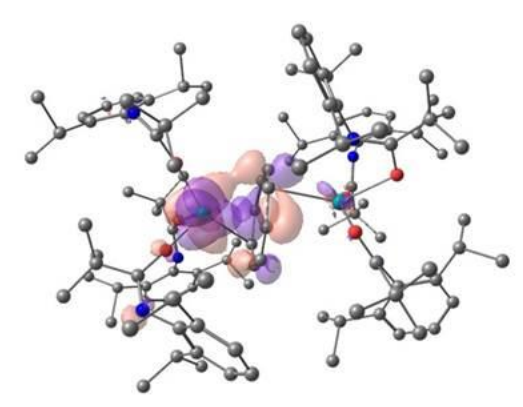

somo

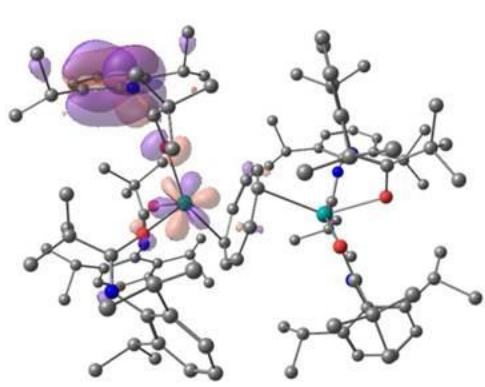

somo

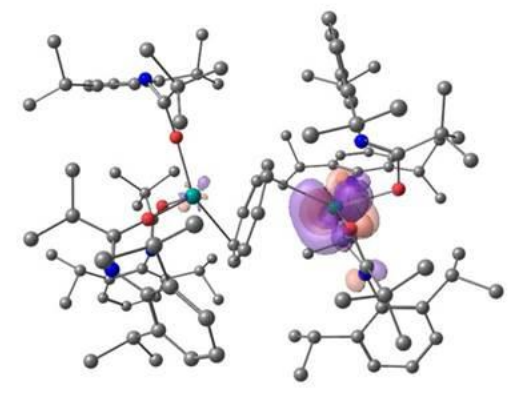

LUMO
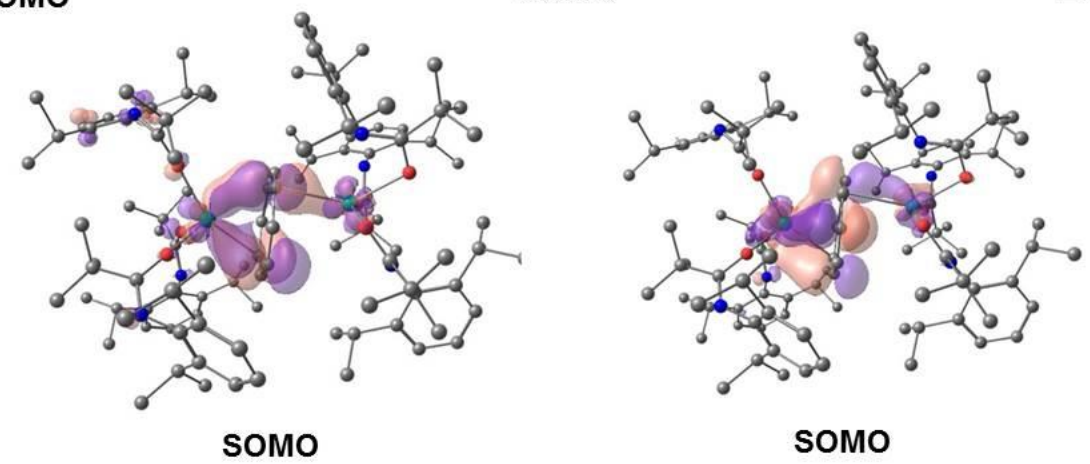

Figure S58: Selected molecular orbitals for the ground state of $\mathbf{8}$ calculated using DFT. The two bottom SOMOs both display $\delta$-bonding interactions between the 5 fxyz orbitals of both uranium atoms and the $\pi^{*}$ orbitals of the COT ligand, while another SOMO (top left) is formed primarily from the interaction of the $5 f_{\mathrm{xyz}}$ orbital of the left uranium atom with the $\pi^{*}$ orbitals of the COT ligand. An additional SOMO (top center) and the LUMO (top right) contain nonbonding $5 \mathrm{f}_{\mathrm{xyz}}$ orbitals on the left and right uranium atoms, respectively. 
Geometry-optimized coordinates for $\mathbf{2}, \mathbf{3}, \mathbf{5}, \mathbf{7}$, and $\mathbf{8}$ :

\section{Complex 2- one arene bound}

\begin{tabular}{|c|c|c|c|}
\hline I & 10.061424000 & 9.552907000 & 13.990289000 \\
\hline $\mathrm{O}$ & 8.559345000 & 9.042924000 & 15.705189000 \\
\hline $\mathrm{O}$ & 12.029048000 & 8.859581000 & 15.012976000 \\
\hline$O$ & 10.864476000 & 11.601640000 & 13.252633000 \\
\hline $\mathrm{N}$ & 9.468496000 & 12.073519000 & 11.483114000 \\
\hline $\mathrm{N}$ & 9.390024000 & 11.058946000 & 16.064399000 \\
\hline $\mathrm{N}$ & 11.133638000 & 7.073127000 & 14.060043000 \\
\hline $\mathrm{C}$ & 9.074659000 & 10.741413000 & 11.573211000 \\
\hline $\mathrm{C}$ & 9.904150000 & 4.973742000 & 14.444209000 \\
\hline $\mathrm{C}$ & 9.111896000 & 14.576458000 & 17.272186000 \\
\hline $\mathrm{H}$ & 8.389327000 & 15.388941000 & 17.272505000 \\
\hline $\mathrm{C}$ & 11.549400000 & 5.115680000 & 12.632266000 \\
\hline $\mathrm{C}$ & 8.416080000 & 10.851451000 & 19.000138000 \\
\hline$H$ & 9.482304000 & 11.015119000 & 19.170550000 \\
\hline $\mathrm{H}$ & 7.972424000 & 10.526196000 & 19.948287000 \\
\hline $\mathrm{H}$ & 7.975654000 & 11.813515000 & 18.737573000 \\
\hline $\mathrm{C}$ & 10.889549000 & 5.712187000 & 13.739387000 \\
\hline $\mathrm{C}$ & 9.106417000 & 5.554787000 & 15.603071000 \\
\hline $\mathrm{H}$ & 9.494348000 & 6.554236000 & 15.818737000 \\
\hline $\mathrm{C}$ & 12.009070000 & 7.558281000 & 14.908252000 \\
\hline $\mathrm{C}$ & 8.737633000 & 10.030106000 & 16.545196000 \\
\hline $\mathrm{C}$ & 9.693139000 & 12.289878000 & 16.705025000 \\
\hline $\mathrm{C}$ & 8.159078000 & 9.766962000 & 17.949461000 \\
\hline $\mathrm{C}$ & 9.913005000 & 9.727375000 & 11.015174000 \\
\hline
\end{tabular}




\begin{tabular}{|c|c|c|c|}
\hline $\mathrm{C}$ & 10.976891000 & 12.495078000 & 17.268558000 \\
\hline $\mathrm{C}$ & 10.403341000 & 12.409595000 & 12.327152000 \\
\hline $\mathrm{C}$ & 10.903800000 & 9.454002000 & 8.724013000 \\
\hline $\mathrm{H}$ & 10.973224000 & 8.362013000 & 8.773567000 \\
\hline $\mathrm{H}$ & 11.689130000 & 9.803000000 & 8.044987000 \\
\hline $\mathrm{H}$ & 9.936287000 & 9.710903000 & 8.281802000 \\
\hline $\mathrm{C}$ & 9.643036000 & 3.654551000 & 14.061477000 \\
\hline $\mathrm{H}$ & 8.891531000 & 3.088049000 & 14.605628000 \\
\hline $\mathrm{C}$ & 12.553287000 & 5.869703000 & 11.770375000 \\
\hline $\mathrm{H}$ & 12.474442000 & 6.928320000 & 12.041059000 \\
\hline $\mathrm{C}$ & 11.075908000 & 10.100408000 & 10.106314000 \\
\hline $\mathrm{H}$ & 11.020635000 & 11.184081000 & 9.971568000 \\
\hline $\mathrm{C}$ & 10.360842000 & 14.778353000 & 17.843203000 \\
\hline $\mathrm{H}$ & 10.615781000 & 15.735913000 & 18.288793000 \\
\hline $\mathrm{C}$ & 13.008440000 & 6.851156000 & 15.847331000 \\
\hline $\mathrm{C}$ & 8.757136000 & 13.356028000 & 16.688922000 \\
\hline $\mathrm{C}$ & 11.281589000 & 13.739501000 & 17.827259000 \\
\hline $\mathrm{H}$ & 12.266202000 & 13.893991000 & 18.261031000 \\
\hline $\mathrm{C}$ & 12.450235000 & 9.773351000 & 10.702324000 \\
\hline $\mathrm{H}$ & 12.588976000 & 10.254269000 & 11.674795000 \\
\hline $\mathrm{H}$ & 13.244972000 & 10.128080000 & 10.036920000 \\
\hline $\mathrm{H}$ & 12.586381000 & 8.694387000 & 10.827190000 \\
\hline $\mathrm{C}$ & 13.071170000 & 5.322801000 & 15.758014000 \\
\hline $\mathrm{H}$ & 12.123597000 & 4.851815000 & 16.024276000 \\
\hline $\mathrm{H}$ & 13.829880000 & 4.967925000 & 16.465053000 \\
\hline $\mathrm{H}$ & 13.347132000 & 4.961788000 & 14.766681000 \\
\hline $\mathrm{C}$ & 10.322129000 & 3.048758000 & 13.013218000 \\
\hline
\end{tabular}




\begin{tabular}{cccc}
$\mathrm{H}$ & 10.112880000 & 2.017686000 & 12.742162000 \\
$\mathrm{C}$ & 9.609794000 & 8.386490000 & 11.276553000 \\
$\mathrm{H}$ & 10.272260000 & 7.610826000 & 10.908429000 \\
$\mathrm{C}$ & 10.314447000 & 14.684719000 & 11.233268000 \\
$\mathrm{H}$ & 10.266539000 & 14.234401000 & 10.238604000 \\
$\mathrm{H}$ & 10.822400000 & 15.652677000 & 11.155015000 \\
$\mathrm{H}$ & 9.286700000 & 14.863651000 & 11.562573000 \\
$\mathrm{C}$ & 11.263653000 & 3.786246000 & 12.307774000 \\
$\mathrm{H}$ & 11.788041000 & 3.322292000 & 11.476482000 \\
$\mathrm{C}$ & 8.477235000 & 8.023214000 & 12.014521000 \\
$\mathrm{H}$ & 8.279727000 & 6.977243000 & 12.224250000 \\
$\mathrm{C}$ & 8.784088000 & 8.452685000 & 18.455774000 \\
$\mathrm{H}$ & 9.866664000 & 8.552803000 & 18.585835000 \\
$\mathrm{H}$ & 8.592792000 & 7.635159000 & 17.759181000 \\
$\mathrm{H}$ & 8.352046000 & 8.194146000 & 19.428666000 \\
$\mathrm{C}$ & 11.064658000 & 13.784929000 & 12.219438000 \\
$\mathrm{C}$ & 7.845840000 & 10.377821000 & 12.204132000 \\
$\mathrm{C}$ & 12.050942000 & 11.418535000 & 17.279485000 \\
$\mathrm{H}$ & 11.608732000 & 10.490494000 & 16.907551000 \\
$\mathrm{C}$ & 6.640919000 & 9.559314000 & 17.782091000 \\
$\mathrm{H}$ & 6.196364000 & 9.300367000 & 18.749357000 \\
$\mathrm{H}$ & 6.434813000 & 8.751763000 & 17.076010000 \\
$\mathrm{H}$ & 6.149210000 & 10.467770000 & 17.420379000 \\
$\mathrm{H}$ & 12.503928000 & 13.554628000 & 11.714961000 \\
$\mathrm{H}$ & 13.057494000 & 12.901661000 & 12.395286000 \\
\hline & 13.032929000 & 14.511879000 & 11.650986000 \\
$\mathrm{H}$ & 12.509670000 & 13.102016000 & 10.717455000
\end{tabular}




\begin{tabular}{lrrr}
$\mathrm{C}$ & 7.581537000 & 9.016555000 & 12.424738000 \\
$\mathrm{H}$ & 6.674685000 & 8.726751000 & 12.943761000 \\
$\mathrm{C}$ & 12.610532000 & 7.233539000 & 17.287105000 \\
$\mathrm{H}$ & 12.596118000 & 8.317337000 & 17.414691000 \\
$\mathrm{H}$ & 13.333891000 & 6.808207000 & 17.991392000 \\
$\mathrm{H}$ & 11.622073000 & 6.838831000 & 17.543321000 \\
$\mathrm{C}$ & 12.588513000 & 11.142303000 & 18.691341000 \\
$\mathrm{H}$ & 13.094748000 & 12.017765000 & 19.112285000 \\
$\mathrm{H}$ & 13.319843000 & 10.326957000 & 18.667055000 \\
$\mathrm{H}$ & 11.790547000 & 10.858294000 & 19.384914000 \\
$\mathrm{C}$ & 9.233906000 & 4.712651000 & 16.881826000 \\
$\mathrm{H}$ & 8.814264000 & 3.709550000 & 16.748521000 \\
$\mathrm{H}$ & 8.688652000 & 5.185599000 & 17.705751000 \\
$\mathrm{H}$ & 10.275740000 & 4.594466000 & 17.194072000 \\
$\mathrm{C}$ & 6.238572000 & 13.474256000 & 17.055650000 \\
$\mathrm{H}$ & 6.283446000 & 12.778786000 & 17.897771000 \\
$\mathrm{H}$ & 5.266499000 & 13.346404000 & 16.566120000 \\
$\mathrm{H}$ & 6.266834000 & 14.489233000 & 17.466901000 \\
$\mathrm{C}$ & 7.378545000 & 13.249556000 & 16.049832000 \\
$\mathrm{H}$ & 7.276761000 & 12.239590000 & 15.640885000 \\
$\mathrm{C}$ & 6.838362000 & 11.457199000 & 12.559503000 \\
$\mathrm{H}$ & 7.388662000 & 12.250302000 & 13.075641000 \\
$\mathrm{C}$ & 6.263988000 & 12.070274000 & 11.270065000 \\
$\mathrm{H}$ & 7.061592000 & 12.482601000 & 10.648041000 \\
\hline & 5.564736000 & 12.877405000 & 11.513614000 \\
\hline
\end{tabular}




\begin{tabular}{|c|c|c|c|}
\hline & 1473 & 0 & 14.5 \\
\hline & 15.132808000 & 7.018120000 & 16.253625000 \\
\hline & 4.398 & 523569000 & 5.65512900 \\
\hline & 7.625489000 & .716490000 & 5.230204000 \\
\hline & 0 & 0 & 00 \\
\hline & 7.064 & 0 & 5000 \\
\hline & 7.169 & 000 & 14.9 \\
\hline & 7.229 & 000 & 5000 \\
\hline & 7.305109000 & 15.278927000 & 15.243338000 \\
\hline & 5000 & 14.13 & 000 \\
\hline & 0 & 14.0 & 1000 \\
\hline & 11.12 & 14.4 & 13. \\
\hline & 0 & 14. & 13 \\
\hline & 11.674047000 & 15.40 & 13.523 \\
\hline & 11.63 & 13.8 & 14. \\
\hline & 13.201 & 11.78 & 16. \\
\hline & 12.8400 & 11.91 & 15 \\
\hline & 0 & 10. & \\
\hline & 1 & 12 & \\
\hline & 12 & 0 & 10 \\
\hline & 12.4 & 4.7 & 00 \\
\hline & 12.859 & 6.41 & 9.6 \\
\hline & 11.190 & 5.92 & 10 \\
\hline & 5.7 & 10.97 & 13.4 \\
\hline & 5.054463000 & 0 & 12. \\
\hline & 0.00 & 11.8 & 10.1 \\
\hline & 08486 & 038390 & \\
\hline
\end{tabular}




$\begin{array}{llll}\mathrm{C} & 14.004433000 & 5.427847000 & 12.014486000 \\ \mathrm{H} & 14.320838000 & 5.595284000 & 13.046027000 \\ \mathrm{H} & 14.689156000 & 5.981888000 & 11.362432000 \\ \mathrm{H} & 14.128055000 & 4.360719000 & 11.797799000\end{array}$

\section{Complex 2- two arenes bound}

$\begin{array}{llll}\text { C } & -2.918177000 & 3.456686000 & 11.118137000\end{array}$

$\begin{array}{llll}\text { C } & -2.420126000 & 3.900197000 & 12.372019000\end{array}$

$\begin{array}{llll}\text { C } & -1.470130000 & 4.962162000 & 12.443188000\end{array}$

$\begin{array}{llll}\text { C } & -1.164161000 & 5.656370000 & 11.268348000\end{array}$

$\begin{array}{llll}\text { C } & -1.756284000 & 5.316753000 & 10.047526000\end{array}$

$\begin{array}{llll}\text { C } & -2.585908000 & 4.197906000 & 9.975685000\end{array}$

$\begin{array}{llll}\mathrm{N} & -2.860063000 & 3.303686000 & 13.548562000\end{array}$

$\begin{array}{llll}\text { C } & -3.764065000 & 3.997083000 & 14.173748000\end{array}$

$\begin{array}{llll}\text { C } & -4.260262000 & 3.538028000 & 15.545748000\end{array}$

$\begin{array}{llll}\text { C } & -5.795844000 & 3.521840000 & 15.562744000\end{array}$

$\begin{array}{llll}\text { C } & -0.778409000 & 5.258143000 & 13.766546000\end{array}$

$\begin{array}{llll}\text { C } & -0.141033000 & 6.644334000 & 13.846997000\end{array}$

$\begin{array}{llll}\text { C } & -3.720992000 & 2.164658000 & 11.049885000\end{array}$

$\begin{array}{llll}\text { C } & -4.359879000 & 1.886007000 & 9.688483000\end{array}$

$\begin{array}{llll}\text { O } & -4.254440000 & 5.121649000 & 13.709349000\end{array}$

$\begin{array}{llll}\text { U } & -3.996754000 & 6.556887000 & 11.904686000\end{array}$

$\begin{array}{llll}\text { O } & -5.076566000 & 7.911460000 & 13.408662000\end{array}$

$\begin{array}{llll}\text { C } & -6.344787000 & 8.201183000 & 13.569237000\end{array}$

$\begin{array}{llll}\text { C } & -6.729569000 & 8.905844000 & 14.868571000\end{array}$

$\begin{array}{llll}\text { C } & -6.237968000 & 8.057361000 & 16.053166000\end{array}$

$\begin{array}{llll}\mathrm{N} & -7.255880000 & 7.928355000 & 12.680193000\end{array}$ 


\begin{tabular}{lrrr}
$\mathrm{C}$ & -6.749374000 & 7.320106000 & 11.536274000 \\
$\mathrm{C}$ & -6.126226000 & 8.118596000 & 10.526088000 \\
$\mathrm{C}$ & -5.453350000 & 7.470965000 & 9.480271000 \\
$\mathrm{C}$ & -5.432895000 & 6.072821000 & 9.392103000 \\
$\mathrm{C}$ & -6.168401000 & 5.309748000 & 10.308400000 \\
$\mathrm{C}$ & -6.853509000 & 5.909298000 & 11.375725000 \\
$\mathrm{C}$ & -6.280814000 & 9.629858000 & 10.581659000 \\
$\mathrm{C}$ & -5.390902000 & 10.381042000 & 9.596670000 \\
$\mathrm{C}$ & -7.727925000 & 5.112453000 & 12.329209000 \\
$\mathrm{C}$ & -7.534008000 & 3.600944000 & 12.234047000 \\
$\mathrm{C}$ & -6.021288000 & 10.272613000 & 14.900334000 \\
$\mathrm{C}$ & -8.244386000 & 9.105045000 & 14.963453000 \\
$\mathrm{C}$ & -9.204663000 & 5.479777000 & 12.099058000 \\
$\mathrm{C}$ & -7.757197000 & 10.003312000 & 10.357331000 \\
$\mathrm{C}$ & -3.722150000 & 2.147186000 & 15.892037000 \\
$\mathrm{C}$ & -3.757634000 & 4.561105000 & 16.583127000 \\
$\mathrm{C}$ & 0.260775000 & 4.162029000 & 14.057142000 \\
$\mathrm{C}$ & -2.827425000 & 0.976111000 & 11.449913000 \\
$\mathrm{H}$ & -1.537098000 & 5.200574000 & 14.553603000 \\
$\mathrm{H}$ & -7.467092000 & 5.429032000 & 13.345449000 \\
$\mathrm{H}$ & -4.518715000 & 2.232172000 & 11.800377000 \\
$\mathrm{H}$ & -2.663070000 & 4.572170000 & 16.628349000 \\
$\mathrm{H}$ & -4.129125000 & 4.298062000 & 17.579752000 \\
$\mathrm{H}$ & -4.105469000 & 5.568157000 & 16.339489000 \\
\hline & 0.715689000 & 6.740021000 & 13.171103000 \\
\hline & -0.856611000 & 7.435912000 & 13.602751000
\end{tabular}




\begin{tabular}{lrrr}
$\mathrm{H}$ & -6.198652000 & 4.497938000 & 15.282244000 \\
$\mathrm{H}$ & -6.157400000 & 3.272422000 & 16.566361000 \\
$\mathrm{H}$ & -6.191513000 & 2.771987000 & 14.870149000 \\
$\mathrm{H}$ & -6.009185000 & 9.950474000 & 11.593809000 \\
$\mathrm{H}$ & -5.000304000 & 2.702187000 & 9.339558000 \\
$\mathrm{H}$ & -4.978027000 & 0.985001000 & 9.748262000 \\
$\mathrm{H}$ & -3.601087000 & 1.704994000 & 8.918324000 \\
$\mathrm{H}$ & -7.862113000 & 3.208109000 & 11.264388000 \\
$\mathrm{H}$ & -8.133789000 & 3.102888000 & 13.001498000 \\
$\mathrm{H}$ & -6.489725000 & 3.315247000 & 12.388832000 \\
$\mathrm{H}$ & -4.059079000 & 1.399654000 & 15.167936000 \\
$\mathrm{H}$ & -4.076467000 & 1.848419000 & 16.885188000 \\
$\mathrm{H}$ & -2.629486000 & 2.133527000 & 15.894164000 \\
$\mathrm{H}$ & -4.337125000 & 10.123024000 & 9.726849000 \\
$\mathrm{H}$ & -5.495778000 & 11.459262000 & 9.750963000 \\
$\mathrm{H}$ & -5.669669000 & 10.176349000 & 8.556449000 \\
$\mathrm{H}$ & -9.365703000 & 6.550684000 & 12.239614000 \\
$\mathrm{H}$ & -9.841201000 & 4.939572000 & 12.807901000 \\
$\mathrm{H}$ & -9.520198000 & 5.204888000 & 11.086092000 \\
$\mathrm{H}$ & -8.619403000 & 9.710738000 & 14.134320000 \\
$\mathrm{H}$ & -8.493739000 & 9.611247000 & 15.902858000 \\
$\mathrm{H}$ & -8.772922000 & 8.148050000 & 14.937373000 \\
$\mathrm{H}$ & -0.208752000 & 3.175221000 & 14.075735000 \\
$\mathrm{H}$ & 0.737153000 & 4.334459000 & 15.028485000 \\
\hline & -3.405913000 & 0.045871000 & 11.438129000
\end{tabular}




\begin{tabular}{|c|c|c|c|}
\hline $\mathrm{H}$ & -2.420445000 & 1.116643000 & 12.453121000 \\
\hline $\mathrm{H}$ & -8.085418000 & 9.698293000 & 9.357196000 \\
\hline $\mathrm{H}$ & -7.886074000 & 11.087985000 & 10.436682000 \\
\hline $\mathrm{H}$ & -8.400448000 & 9.524986000 & 11.099059000 \\
\hline $\mathrm{H}$ & -6.727915000 & 7.078087000 & 16.069173000 \\
\hline $\mathrm{H}$ & -6.467724000 & 8.563584000 & 16.997197000 \\
\hline $\mathrm{H}$ & -5.158619000 & 7.898356000 & 15.996648000 \\
\hline $\mathrm{H}$ & -4.937957000 & 10.154208000 & 14.821598000 \\
\hline $\mathrm{H}$ & -6.246366000 & 10.788860000 & 15.840182000 \\
\hline $\mathrm{H}$ & -6.359899000 & 10.913609000 & 14.078756000 \\
\hline $\mathrm{H}$ & -6.204193000 & 4.232670000 & 10.194445000 \\
\hline $\mathrm{H}$ & -0.485436000 & 6.499134000 & 11.286964000 \\
\hline $\mathrm{H}$ & -1.534380000 & 5.913526000 & 9.169556000 \\
\hline $\mathrm{H}$ & -4.897246000 & 5.588204000 & 8.583042000 \\
\hline $\mathrm{H}$ & -2.981019000 & 3.894512000 & 9.011153000 \\
\hline $\mathrm{H}$ & -4.930702000 & 8.054486000 & 8.730419000 \\
\hline $\mathrm{O}$ & -2.604180000 & 8.246331000 & 11.526091000 \\
\hline $\mathrm{C}$ & -1.692168000 & 9.063445000 & 11.016113000 \\
\hline $\mathrm{N}$ & -1.043585000 & 8.675948000 & 9.971937000 \\
\hline $\mathrm{C}$ & -1.521312000 & 10.401814000 & 11.794913000 \\
\hline $\mathrm{C}$ & -0.079020000 & 9.358216000 & 9.214355000 \\
\hline $\mathrm{C}$ & 1.307944000 & 9.167169000 & 9.452344000 \\
\hline $\mathrm{C}$ & 2.235060000 & 9.789857000 & 8.611378000 \\
\hline $\mathrm{C}$ & 1.837139000 & 10.564079000 & 7.529540000 \\
\hline $\mathrm{C}$ & 0.479622000 & 10.687290000 & 7.255263000 \\
\hline $\mathrm{C}$ & -0.487239000 & 10.086222000 & 8.062614000 \\
\hline 0 & 1.803152000 & 8.212265000 & 10.527096000 \\
\hline
\end{tabular}




\begin{tabular}{lrrr}
$\mathrm{H}$ & 3.295707000 & 9.654098000 & 8.805212000 \\
$\mathrm{H}$ & 2.574808000 & 11.046063000 & 6.894110000 \\
$\mathrm{H}$ & 0.163056000 & 11.257451000 & 6.386452000 \\
$\mathrm{C}$ & -1.951327000 & 10.130013000 & 7.656070000 \\
$\mathrm{C}$ & -0.088914000 & 10.509568000 & 12.346008000 \\
$\mathrm{C}$ & -1.780931000 & 11.609802000 & 10.877178000 \\
$\mathrm{C}$ & -2.499988000 & 10.472872000 & 12.973535000 \\
$\mathrm{H}$ & -0.000879000 & 11.421986000 & 12.946995000 \\
$\mathrm{H}$ & 0.160497000 & 9.662295000 & 12.992687000 \\
$\mathrm{H}$ & 0.647992000 & 10.565645000 & 11.542582000 \\
$\mathrm{H}$ & -1.659349000 & 12.532058000 & 11.456980000 \\
$\mathrm{H}$ & -1.082309000 & 11.647142000 & 10.038902000 \\
$\mathrm{H}$ & -2.800548000 & 11.604503000 & 10.481093000 \\
$\mathrm{H}$ & -2.375352000 & 11.433828000 & 13.485916000 \\
$\mathrm{H}$ & -3.538093000 & 10.389277000 & 12.645597000 \\
$\mathrm{H}$ & -2.322232000 & 9.675691000 & 13.699819000 \\
$\mathrm{C}$ & 3.023565000 & 8.717744000 & 11.305727000 \\
$\mathrm{H}$ & 0.990225000 & 8.080893000 & 11.248045000 \\
$\mathrm{C}$ & 2.102651000 & 6.840329000 & 9.900995000 \\
$\mathrm{H}$ & -2.545170000 & 9.996465000 & 8.564004000 \\
$\mathrm{C}$ & -2.387696000 & 11.449291000 & 7.012576000 \\
$\mathrm{C}$ & -2.267764000 & 8.942687000 & 6.732441000 \\
$\mathrm{H}$ & 3.259507000 & 8.030152000 & 12.125485000 \\
$\mathrm{H}$ & 3.916291000 & 8.777337000 & 10.673877000 \\
& 2.851854000 & 9.709161000 & 11.735259000 \\
$\mathrm{H}$ & 2.395903000 & 6.111018000 & 10.665468000 \\
\hline
\end{tabular}




$\begin{array}{llll}\mathrm{H} & 2.922954000 & 6.919934000 & 9.178826000 \\ \mathrm{H} & -3.472719000 & 11.454239000 & 6.861200000 \\ \mathrm{H} & -2.129260000 & 12.309239000 & 7.638347000 \\ \mathrm{H} & -1.929687000 & 11.600700000 & 6.028847000 \\ \mathrm{H} & -3.331635000 & 8.922364000 & 6.465318000 \\ \mathrm{H} & -1.690511000 & 9.009167000 & 5.803319000 \\ \mathrm{H} & -2.014117000 & 7.996026000 & 7.218603000\end{array}$

\section{Complex 3- formal U(III)}
C $\quad-5.119355000$
$8.115842000 \quad 10.688681000$
$\begin{array}{llll}\text { C } & -6.225369000 & 7.864022000 & 11.634536000\end{array}$
$\begin{array}{llll}\text { C } & -7.004785000 & 6.712241000 & 11.558405000\end{array}$
$\begin{array}{llll}\text { C } & -6.642758000 & 5.651349000 & 10.635126000\end{array}$
$\begin{array}{llll}\text { C } & -5.755150000 & 6.016588000 & 9.557890000\end{array}$
$\begin{array}{llll}\text { C } & -5.065155000 & 7.218607000 & 9.574551000\end{array}$
$\begin{array}{llll}\mathrm{N} & -6.359899000 & 8.755815000 & 12.727198000\end{array}$
$\begin{array}{llll}\text { C } & -5.488231000 & 8.502987000 & 13.656357000\end{array}$
$\begin{array}{llll}\text { C } & -5.449145000 & 9.376065000 & 14.916953000\end{array}$
$\begin{array}{llll}\text { C } & -4.049344000 & 10.000659000 & 15.040064000\end{array}$
$\begin{array}{llll}\text { C } & -8.174267000 & 6.507767000 & 12.507811000\end{array}$
$\begin{array}{llll}\text { C } & -9.495722000 & 6.667096000 & 11.738035000\end{array}$
$\begin{array}{llll}\text { U } & -4.408213000 & 5.920938000 & 11.894562000\end{array}$
$\begin{array}{llll}\text { O } & -4.624951000 & 7.517586000 & 13.615571000\end{array}$
$\begin{array}{llll}\text { C } & -4.541000000 & 9.519575000 & 10.597950000\end{array}$
$\begin{array}{llll}\text { C } & -5.534137000 & 10.493129000 & 9.938658000\end{array}$
$\begin{array}{llll}\text { O } & -4.698233000 & 4.384344000 & 13.702720000\end{array}$
$\begin{array}{llll}\text { C } & -3.923368000 & 3.393136000 & 14.039513000\end{array}$ 


\begin{tabular}{lrll}
$\mathrm{C}$ & -4.383526000 & 2.551774000 & 15.237061000 \\
$\mathrm{C}$ & -3.361439000 & 1.468044000 & 15.588036000 \\
$\mathrm{~N}$ & -2.811662000 & 3.088979000 & 13.431715000 \\
$\mathrm{C}$ & -2.553828000 & 3.940100000 & 12.340057000 \\
$\mathrm{C}$ & -1.831561000 & 5.139373000 & 12.541869000 \\
$\mathrm{C}$ & -1.726203000 & 6.077354000 & 11.470603000 \\
$\mathrm{C}$ & -2.249951000 & 5.748118000 & 10.201251000 \\
$\mathrm{C}$ & -2.926387000 & 4.536397000 & 10.001744000 \\
$\mathrm{C}$ & -3.130757000 & 3.616563000 & 11.059306000 \\
$\mathrm{C}$ & -1.208619000 & 5.418729000 & 13.902851000 \\
$\mathrm{C}$ & 0.066131000 & 4.577757000 & 14.077536000 \\
$\mathrm{C}$ & -3.723823000 & 2.235457000 & 10.832996000 \\
$\mathrm{C}$ & -2.601564000 & 1.188391000 & 10.718958000 \\
$\mathrm{C}$ & -0.932672000 & 6.899401000 & 14.172323000 \\
$\mathrm{C}$ & -8.146920000 & 5.170344000 & 13.257545000 \\
$\mathrm{C}$ & -4.586894000 & 3.488604000 & 16.439351000 \\
$\mathrm{C}$ & -5.728793000 & 1.899824000 & 14.872876000 \\
$\mathrm{C}$ & -4.668591000 & 2.149911000 & 9.633790000 \\
$\mathrm{C}$ & -3.183556000 & 9.578584000 & 9.894578000 \\
$\mathrm{C}$ & -6.505550000 & 10.482137000 & 14.860916000 \\
$\mathrm{C}$ & -5.703976000 & 8.471048000 & 16.134665000 \\
$\mathrm{H}$ & -1.921914000 & 5.076902000 & 14.661729000 \\
$\mathrm{H}$ & -8.123521000 & 7.313903000 & 13.246989000 \\
$\mathrm{H}$ & -4.305313000 & 1.983475000 & 11.726447000 \\
$\mathrm{H}$ & -3.639541000 & 3.948914000 & 16.742346000 \\
& -4.980317000 & 2.930694000 & 17.298374000 \\
\hline & -5.285748000 & 4.289637000 & 16.187413000
\end{tabular}




\begin{tabular}{lrrr}
$\mathrm{H}$ & -0.142925000 & 7.295243000 & 13.521921000 \\
$\mathrm{H}$ & -0.594699000 & 7.033214000 & 15.206413000 \\
$\mathrm{H}$ & -1.833846000 & 7.503023000 & 14.027211000 \\
$\mathrm{H}$ & -6.461433000 & 2.659761000 & 14.590039000 \\
$\mathrm{H}$ & -6.122664000 & 1.331157000 & 15.724690000 \\
$\mathrm{H}$ & -5.613364000 & 1.208244000 & 14.030521000 \\
$\mathrm{H}$ & -4.386559000 & 9.870838000 & 11.624597000 \\
$\mathrm{H}$ & -5.460916000 & 2.901372000 & 9.705640000 \\
$\mathrm{H}$ & -5.135239000 & 1.158791000 & 9.591245000 \\
$\mathrm{H}$ & -4.140315000 & 2.295966000 & 8.683436000 \\
$\mathrm{H}$ & -8.247341000 & 4.321517000 & 12.571367000 \\
$\mathrm{H}$ & -8.980165000 & 5.117454000 & 13.969922000 \\
$\mathrm{H}$ & -7.212197000 & 5.035331000 & 13.809881000 \\
$\mathrm{H}$ & -3.192931000 & 0.797351000 & 14.741278000 \\
$\mathrm{H}$ & -3.716976000 & 0.876047000 & 16.441609000 \\
$\mathrm{H}$ & -2.394880000 & 1.908701000 & 15.848155000 \\
$\mathrm{H}$ & -2.475804000 & 8.890312000 & 10.367232000 \\
$\mathrm{H}$ & -2.767978000 & 10.592744000 & 9.941934000 \\
$\mathrm{H}$ & -3.258303000 & 9.313858000 & 8.832299000 \\
$\mathrm{H}$ & -9.551722000 & 7.649705000 & 11.258955000 \\
$\mathrm{H}$ & -10.356855000 & 6.563002000 & 12.410744000 \\
$\mathrm{H}$ & -9.588420000 & 5.906315000 & 10.953763000 \\
$\mathrm{H}$ & -6.349557000 & 11.129710000 & 13.993877000 \\
\hline & -6.461107000 & 11.094035000 & 15.771710000 \\
\hline & -7.510176000 & 10.060477000 & 14.770084000 \\
$\mathrm{H}$ & -0.507269000 & 4.735028000 & 15.070373000
\end{tabular}




$\begin{array}{lrrr}\mathrm{H} & 0.817400000 & 4.851185000 & 13.326557000 \\ \mathrm{H} & -1.964981000 & 1.396635000 & 9.850173000 \\ \mathrm{H} & -3.013300000 & 0.177156000 & 10.603051000 \\ \mathrm{H} & -1.977015000 & 1.204359000 & 11.616531000 \\ \mathrm{H} & -5.748805000 & 10.187038000 & 8.906965000 \\ \mathrm{H} & -5.140016000 & 11.518572000 & 9.912763000 \\ \mathrm{H} & -6.476454000 & 10.502746000 & 10.494259000 \\ \mathrm{H} & -6.702675000 & 8.022827000 & 16.085296000 \\ \mathrm{H} & -5.637501000 & 9.049469000 & 17.064984000 \\ \mathrm{H} & -4.971764000 & 7.660552000 & 16.169812000 \\ \mathrm{H} & -3.281993000 & 9.223021000 & 15.062119000 \\ \mathrm{H} & -3.973109000 & 10.593543000 & 15.960441000 \\ \mathrm{H} & -3.838634000 & 10.663969000 & 14.193491000 \\ \mathrm{H} & -7.313723000 & 4.808222000 & 10.503985000 \\ \mathrm{H} & -1.165145000 & 6.995230000 & 11.599675000 \\ \mathrm{H} & -2.143073000 & 6.447532000 & 9.378612000 \\ \mathrm{H} & -5.604593000 & 5.323886000 & 8.733984000 \\ \mathrm{H} & -3.323480000 & 4.316284000 & 9.016700000 \\ \mathrm{H} & -4.377216000 & 7.432277000 & 8.759956000\end{array}$

\section{Complex 3- formal U(0)}

$\begin{array}{llll}\mathrm{U} & -4.314204000 & 5.879557000 & 11.684777000 \\ \mathrm{O} & -4.410109000 & 7.544514000 & 13.554921000 \\ \mathrm{O} & -4.909819000 & 4.297528000 & 13.534726000 \\ \mathrm{~N} & -6.268563000 & 8.679121000 & 12.747832000 \\ \mathrm{~N} & -2.891821000 & 3.150095000 & 13.510158000 \\ \mathrm{C} & -5.278161000 & 8.177490000 & 10.546956000\end{array}$



$\begin{array}{llll}\text { C } & -6.174713000 & 7.829767000 & 11.610620000\end{array}$
$\begin{array}{llll}\text { C } & -6.935279000 & 6.607066000 & 11.590375000\end{array}$
$\begin{array}{llll}\text { C } & -6.747072000 & 5.707438000 & 10.493134000\end{array}$
$\begin{array}{llll}\text { C } & -5.859679000 & 6.042287000 & 9.440427000\end{array}$
$\begin{array}{llll}\text { C } & -5.133133000 & 7.258158000 & 9.461168000\end{array}$
$\begin{array}{llll}\text { C } & -5.338079000 & 8.441614000 & 13.633101000\end{array}$
$\begin{array}{llll}\text { C } & -5.325124000 & 9.309574000 & 14.912478000\end{array}$
$\begin{array}{llll}\text { C } & -4.008929000 & 10.103242000 & 14.946637000\end{array}$
$\begin{array}{llll}\text { C } & -8.016709000 & 6.377566000 & 12.628950000\end{array}$
$\begin{array}{llll}\text { C } & -9.323259000 & 7.082195000 & 12.217085000\end{array}$
$\begin{array}{llll}\text { C } & -4.649117000 & 9.559473000 & 10.519317000\end{array}$
$\begin{array}{llll}\text { C } & -5.688060000 & 10.621297000 & 10.114270000\end{array}$
$\begin{array}{llll}\text { C } & -4.080115000 & 3.413716000 & 13.983880000\end{array}$
$\begin{array}{llll}\text { C } & -4.570182000 & 2.593579000 & 15.199371000\end{array}$
$\begin{array}{llll}\text { C } & -3.482034000 & 1.656649000 & 15.728713000\end{array}$
$\begin{array}{llll}\text { C } & -2.564193000 & 3.947987000 & 12.378651000\end{array}$
$\begin{array}{llll}\text { C } & -1.840117000 & 5.176933000 & 12.578523000\end{array}$
$\begin{array}{llll}\text { C } & -1.617178000 & 6.026056000 & 11.447794000\end{array}$
$\begin{array}{llll}\text { C } & -2.071838000 & 5.636906000 & 10.163146000\end{array}$
$\begin{array}{llll}\text { C } & -2.764096000 & 4.415050000 & 9.975493000\end{array}$
$\begin{array}{llll}\text { C } & -3.019650000 & 3.543921000 & 11.080261000\end{array}$
$\begin{array}{llll}\text { C } & -1.211286000 & 5.464761000 & 13.929003000\end{array}$
$\begin{array}{llll}\text { C } & 0.134922000 & 4.728917000 & 14.068788000\end{array}$
$\begin{array}{llll}\text { C } & -3.604498000 & 2.155039000 & 10.891681000\end{array}$
$\begin{array}{llll}\text { C } & -2.499362000 & 1.085228000 & 10.956268000\end{array}$
$\begin{array}{llll}\text { C } & -1.055557000 & 6.956185000 & 14.236153000\end{array}$
$\begin{array}{llll}\text { C } & -8.267732000 & 4.901314000 & 12.947009000\end{array}$ 


\begin{tabular}{lrll}
$\mathrm{C}$ & -4.999466000 & 3.572899000 & 16.302466000 \\
$\mathrm{C}$ & -5.791217000 & 1.768144000 & 14.760902000 \\
$\mathrm{C}$ & -4.434794000 & 1.995692000 & 9.616333000 \\
$\mathrm{C}$ & -3.403002000 & 9.662114000 & 9.637041000 \\
$\mathrm{C}$ & -6.508824000 & 10.279167000 & 14.952975000 \\
$\mathrm{C}$ & -5.375268000 & 8.372784000 & 16.129275000 \\
$\mathrm{H}$ & -1.876951000 & 5.039369000 & 14.689347000 \\
$\mathrm{H}$ & -7.680058000 & 6.862472000 & 13.552818000 \\
$\mathrm{H}$ & -4.274242000 & 1.964920000 & 11.739237000 \\
$\mathrm{H}$ & -4.141166000 & 4.149642000 & 16.666105000 \\
$\mathrm{H}$ & -5.435991000 & 3.035517000 & 17.156888000 \\
$\mathrm{H}$ & -5.732080000 & 4.280846000 & 15.908196000 \\
$\mathrm{H}$ & -0.322915000 & 7.434320000 & 13.572341000 \\
$\mathrm{H}$ & -0.699234000 & 7.102755000 & 15.265521000 \\
$\mathrm{H}$ & -2.016707000 & 7.465997000 & 14.116090000 \\
$\mathrm{H}$ & -6.563062000 & 2.422090000 & 14.346949000 \\
$\mathrm{H}$ & -6.216103000 & 1.213367000 & 15.610110000 \\
$\mathrm{H}$ & -5.511550000 & 1.042564000 & 13.987891000 \\
$\mathrm{H}$ & -4.340464000 & 9.798092000 & 11.544249000 \\
$\mathrm{H}$ & -5.201530000 & 2.775035000 & 9.557580000 \\
$\mathrm{H}$ & -4.928199000 & 1.014477000 & 9.596381000 \\
$\mathrm{H}$ & -3.811640000 & 2.064809000 & 8.715219000 \\
$\mathrm{H}$ & -8.705480000 & 4.369851000 & 12.091487000 \\
$\mathrm{H}$ & -8.974899000 & 4.800924000 & 13.782437000 \\
$\mathrm{H}$ & -7.326494000 & 4.410597000 & 13.214478000 \\
\hline & -3.156935000 & 0.961341000 & 14.950270000 \\
\hline
\end{tabular}




\begin{tabular}{crcc}
$\mathrm{H}$ & -2.598953000 & 2.223381000 & 16.037303000 \\
$\mathrm{H}$ & -2.672779000 & 8.893206000 & 9.910116000 \\
$\mathrm{H}$ & -2.931715000 & 10.648286000 & 9.747590000 \\
$\mathrm{H}$ & -3.646453000 & 9.535786000 & 8.574035000 \\
$\mathrm{H}$ & -9.141452000 & 8.152257000 & 12.076489000 \\
$\mathrm{H}$ & -10.110789000 & 6.961041000 & 12.977430000 \\
$\mathrm{H}$ & -9.700088000 & 6.672438000 & 11.270527000 \\
$\mathrm{H}$ & -6.494813000 & 10.945901000 & 14.086515000 \\
$\mathrm{H}$ & -6.478467000 & 10.884583000 & 15.872029000 \\
$\mathrm{H}$ & -7.457064000 & 9.735339000 & 14.918984000 \\
$\mathrm{H}$ & -0.013243000 & 3.653881000 & 13.927163000 \\
$\mathrm{H}$ & 0.588059000 & 4.889391000 & 15.059767000 \\
$\mathrm{H}$ & 0.846674000 & 5.079734000 & 13.309778000 \\
$\mathrm{H}$ & -1.772992000 & 1.233011000 & 10.146193000 \\
$\mathrm{H}$ & -2.909583000 & 0.067195000 & 10.864823000 \\
$\mathrm{H}$ & -1.973025000 & 1.164024000 & 11.911828000 \\
$\mathrm{H}$ & -6.062827000 & 10.424627000 & 9.101107000 \\
$\mathrm{H}$ & -5.262500000 & 11.637025000 & 10.129294000 \\
$\mathrm{H}$ & -6.533046000 & 10.587648000 & 10.808067000 \\
$\mathrm{H}$ & -6.322771000 & 7.822318000 & 16.157041000 \\
$\mathrm{H}$ & -5.282637000 & 8.939774000 & 17.066970000 \\
$\mathrm{H}$ & -4.566669000 & 7.640718000 & 16.068804000 \\
$\mathrm{H}$ & -3.154139000 & 9.424684000 & 14.888683000 \\
$\mathrm{H}$ & -3.929978000 & 10.692719000 & 15.871689000 \\
\hline & -3.950729000 & 10.795450000 & 14.098247000 \\
\hline & -7.317733000 & 4.785191000 & 10.441016000 \\
\hline
\end{tabular}




$\begin{array}{llll}\mathrm{H} & -1.938629000 & 6.311132000 & 9.319808000 \\ \mathrm{H} & -5.692029000 & 5.332591000 & 8.633191000 \\ \mathrm{H} & -3.099793000 & 4.145021000 & 8.978735000 \\ \mathrm{H} & -4.457889000 & 7.484760000 & 8.641204000\end{array}$

\section{Complex 3- formal U(I)}

$\begin{array}{llll}\mathrm{U} & -4.330565000 & 5.880683000 & 11.824494000 \\ \mathrm{O} & -4.864498000 & 4.267413000 & 13.491207000 \\ \mathrm{O} & -4.440118000 & 7.561656000 & 13.507298000 \\ \mathrm{~N} & -2.849565000 & 3.135483000 & 13.503395000 \\ \mathrm{~N} & -6.306178000 & 8.680900000 & 12.726556000 \\ \mathrm{C} & -5.257127000 & 8.507046000 & 16.089743000 \\ \mathrm{C} & -6.465774000 & 10.358256000 & 14.897430000 \\ \mathrm{C} & -3.520750000 & 9.582939000 & 9.498960000 \\ \mathrm{C} & -4.304006000 & 2.096778000 & 9.531144000 \\ \mathrm{C} & -5.779844000 & 1.687044000 & 14.605400000 \\ \mathrm{C} & -5.062929000 & 3.450991000 & 16.233896000 \\ \mathrm{C} & -8.434990000 & 4.932927000 & 12.958171000 \\ \mathrm{C} & -0.926629000 & 6.909624000 & 14.336448000 \\ \mathrm{C} & -2.386614000 & 1.184686000 & 10.894861000 \\ \mathrm{C} & -3.514716000 & 2.228560000 & 10.833954000 \\ \mathrm{C} & 0.016631000 & 4.562829000 & 14.271340000 \\ \mathrm{C} & -1.225508000 & 5.439333000 & 14.042834000 \\ \mathrm{C} & -2.958562000 & 3.620150000 & 11.085637000 \\ \mathrm{C} & -2.726733000 & 4.545298000 & 10.046860000 \\ \mathrm{C} & -2.097042000 & 5.785401000 & 10.292855000 \\ \mathrm{C} & -1.610678000 & 6.094336000 & 11.592573000\end{array}$




\begin{tabular}{lrll}
$\mathrm{C}$ & -1.788082000 & 5.180344000 & 12.653216000 \\
$\mathrm{C}$ & -2.511731000 & 3.972797000 & 12.414695000 \\
$\mathrm{C}$ & -3.508688000 & 1.564082000 & 15.661441000 \\
$\mathrm{C}$ & -4.583824000 & 2.508355000 & 15.117842000 \\
$\mathrm{C}$ & -4.050300000 & 3.358965000 & 13.956110000 \\
$\mathrm{C}$ & -5.802149000 & 10.509116000 & 10.043344000 \\
$\mathrm{C}$ & -4.722010000 & 9.487675000 & 10.439497000 \\
$\mathrm{C}$ & -9.272093000 & 7.262326000 & 12.434260000 \\
$\mathrm{C}$ & -8.039343000 & 6.391384000 & 12.727095000 \\
$\mathrm{C}$ & -3.967442000 & 10.194875000 & 14.760974000 \\
$\mathrm{C}$ & -5.278989000 & 9.393527000 & 14.833974000 \\
$\mathrm{C}$ & -5.357835000 & 8.485847000 & 13.598008000 \\
$\mathrm{C}$ & -5.170309000 & 7.127842000 & 9.526356000 \\
$\mathrm{C}$ & -5.855180000 & 5.894010000 & 9.578115000 \\
$\mathrm{C}$ & -6.783956000 & 5.634544000 & 10.622680000 \\
$\mathrm{C}$ & -7.000139000 & 6.593239000 & 11.634940000 \\
$\mathrm{C}$ & -6.230041000 & 7.795163000 & 11.626649000 \\
$\mathrm{C}$ & -5.326925000 & 8.097028000 & 10.538586000 \\
$\mathrm{H}$ & -4.502318000 & 7.320977000 & 8.692330000 \\
$\mathrm{H}$ & -3.046960000 & 4.311724000 & 9.036171000 \\
$\mathrm{H}$ & -5.696948000 & 5.154870000 & 8.799127000 \\
$\mathrm{H}$ & -1.954789000 & 6.489804000 & 9.479409000 \\
$\mathrm{H}$ & -1.076521000 & 7.023895000 & 11.756140000 \\
$\mathrm{H}$ & -7.345513000 & 4.706731000 & 10.617324000 \\
\hline & -3.958637000 & 10.851692000 & 13.883621000 \\
\hline & -3.850405000 & 10.822851000 & 15.653449000 \\
\hline
\end{tabular}




\begin{tabular}{|c|c|c|c|}
\hline $\mathrm{H}$ & -4.434162000 & 7.790492000 & 16.037127000 \\
\hline $\mathrm{H}$ & -5.138372000 & 9.120811000 & 16.991685000 \\
\hline $\mathrm{H}$ & -6.190877000 & 7.941677000 & 16.186494000 \\
\hline $\mathrm{H}$ & -6.623123000 & 10.486378000 & 10.764841000 \\
\hline $\mathrm{H}$ & -5.392022000 & 11.527334000 & 10.015951000 \\
\hline $\mathrm{H}$ & -6.205606000 & 10.278484000 & 9.049690000 \\
\hline $\mathrm{H}$ & -1.878582000 & 1.238235000 & 11.861399000 \\
\hline $\mathrm{H}$ & -2.781110000 & 0.168078000 & 10.766036000 \\
\hline $\mathrm{H}$ & -1.648708000 & 1.365556000 & 10.103608000 \\
\hline $\mathrm{H}$ & 0.808834000 & 4.820254000 & 13.557608000 \\
\hline $\mathrm{H}$ & 0.414486000 & 4.702750000 & 15.284875000 \\
\hline $\mathrm{H}$ & -0.238516000 & 3.507547000 & 14.142457000 \\
\hline $\mathrm{H}$ & -7.412561000 & 9.812902000 & 14.943089000 \\
\hline $\mathrm{H}$ & -6.386141000 & 10.997463000 & 15.786896000 \\
\hline $\mathrm{H}$ & -6.502833000 & 10.993867000 & 14.008909000 \\
\hline $\mathrm{H}$ & -9.742490000 & 6.962397000 & 11.489826000 \\
\hline $\mathrm{H}$ & -10.019857000 & 7.165208000 & 13.232077000 \\
\hline $\mathrm{H}$ & -8.980939000 & 8.313529000 & 12.359386000 \\
\hline $\mathrm{H}$ & -3.806803000 & 9.417390000 & 8.452960000 \\
\hline $\mathrm{H}$ & -3.072919000 & 10.581859000 & 9.556663000 \\
\hline $\mathrm{H}$ & -2.753551000 & 8.848276000 & 9.762366000 \\
\hline $\mathrm{H}$ & -2.645403000 & 2.124469000 & 16.031119000 \\
\hline $\mathrm{H}$ & -3.915688000 & 0.963748000 & 16.485969000 \\
\hline $\mathrm{H}$ & -3.145654000 & 0.891142000 & 14.880399000 \\
\hline $\mathrm{H}$ & -7.552792000 & 4.316117000 & 13.153415000 \\
\hline $\mathrm{H}$ & -9.106328000 & 4.859069000 & 13.821787000 \\
\hline $\mathrm{H}$ & -8.970628000 & 4.513435000 & 12.097535000 \\
\hline
\end{tabular}




$\begin{array}{llll}\mathrm{H} & -3.661560000 & 2.215049000 & 8.649863000 \\ \mathrm{H} & -4.762806000 & 1.103355000 & 9.465078000 \\ \mathrm{H} & -5.099601000 & 2.846489000 & 9.475554000 \\ \mathrm{H} & -4.375654000 & 9.765887000 & 11.441826000 \\ \mathrm{H} & -5.468091000 & 0.988626000 & 13.820329000 \\ \mathrm{H} & -6.221629000 & 1.101084000 & 15.421535000 \\ \mathrm{H} & -6.550796000 & 2.342274000 & 14.191905000 \\ \mathrm{H} & -1.812583000 & 7.528450000 & 14.166174000 \\ \mathrm{H} & -0.618700000 & 7.027399000 & 15.382072000 \\ \mathrm{H} & -0.107936000 & 7.292983000 & 13.714809000 \\ \mathrm{H} & -5.810459000 & 4.149830000 & 15.851531000 \\ \mathrm{H} & -5.501831000 & 2.876089000 & 17.059215000 \\ \mathrm{H} & -4.228950000 & 4.036879000 & 16.636385000 \\ \mathrm{H} & -4.202574000 & 1.999549000 & 11.656571000 \\ \mathrm{H} & -7.602429000 & 6.768638000 & 13.659202000 \\ \mathrm{H} & -1.983067000 & 5.105511000 & 14.762007000\end{array}$

\section{Complex 3- formal U(II)}

$\begin{array}{llll}\mathrm{U} & -4.394865000 & 5.842553000 & 11.772243000 \\ \mathrm{O} & -4.640710000 & 7.426588000 & 13.696012000 \\ \mathrm{O} & -4.829204000 & 4.280676000 & 13.654451000 \\ \mathrm{~N} & -6.298916000 & 8.744267000 & 12.747321000 \\ \mathrm{~N} & -2.829996000 & 3.113872000 & 13.489613000 \\ \mathrm{C} & -5.043255000 & 8.099321000 & 10.710262000 \\ \mathrm{C} & -6.179433000 & 7.865675000 & 11.634542000 \\ \mathrm{C} & -6.993365000 & 6.741437000 & 11.534565000 \\ \mathrm{C} & -6.685274000 & 5.679360000 & 10.579884000\end{array}$




\begin{tabular}{lrrr}
$\mathrm{C}$ & -5.815734000 & 6.074326000 & 9.488084000 \\
$\mathrm{C}$ & -5.059785000 & 7.231667000 & 9.547020000 \\
$\mathrm{C}$ & -5.457813000 & 8.429170000 & 13.694656000 \\
$\mathrm{C}$ & -5.436074000 & 9.311436000 & 14.963932000 \\
$\mathrm{C}$ & -4.032808000 & 9.920461000 & 15.110762000 \\
$\mathrm{C}$ & -8.153555000 & 6.547089000 & 12.498109000 \\
$\mathrm{C}$ & -9.482295000 & 6.821954000 & 11.772292000 \\
$\mathrm{C}$ & -4.507331000 & 9.518054000 & 10.591525000 \\
$\mathrm{C}$ & -5.504812000 & 10.462323000 & 9.891761000 \\
$\mathrm{C}$ & -3.984809000 & 3.379967000 & 14.038029000 \\
$\mathrm{C}$ & -4.413464000 & 2.548468000 & 15.267233000 \\
$\mathrm{C}$ & -3.346909000 & 1.524270000 & 15.661255000 \\
$\mathrm{C}$ & -2.559283000 & 3.936148000 & 12.359589000 \\
$\mathrm{C}$ & -1.871206000 & 5.185148000 & 12.558741000 \\
$\mathrm{C}$ & -1.721141000 & 6.057177000 & 11.437139000 \\
$\mathrm{C}$ & -2.213491000 & 5.690279000 & 10.165935000 \\
$\mathrm{C}$ & -2.893060000 & 4.456834000 & 9.981176000 \\
$\mathrm{C}$ & -3.076805000 & 3.563926000 & 11.078356000 \\
$\mathrm{C}$ & -1.215141000 & 5.475111000 & 13.895711000 \\
$\mathrm{C}$ & 0.110950000 & 4.704292000 & 14.033593000 \\
$\mathrm{C}$ & -3.646413000 & 2.172060000 & 10.865249000 \\
$\mathrm{C}$ & -2.522556000 & 1.180626000 & 10.512809000 \\
$\mathrm{C}$ & -1.015471000 & 6.966378000 & 14.173514000 \\
$\mathrm{C}$ & -8.190046000 & 5.168665000 & 13.170047000 \\
$\mathrm{C}$ & -4.668101000 & 3.515247000 & 16.434308000 \\
\hline & -5.725852000 & 1.826193000 & 14.921476000 \\
\hline & -4.771717000 & 2.110626000 & 9.828691000
\end{tabular}




\begin{tabular}{lrrr}
$\mathrm{C}$ & -3.138077000 & 9.592260000 & 9.910749000 \\
$\mathrm{C}$ & -6.477500000 & 10.430538000 & 14.893620000 \\
$\mathrm{C}$ & -5.716836000 & 8.410305000 & 16.176896000 \\
$\mathrm{H}$ & -1.882366000 & 5.084777000 & 14.673702000 \\
$\mathrm{H}$ & -8.043497000 & 7.306136000 & 13.280254000 \\
$\mathrm{H}$ & -4.062671000 & 1.848406000 & 11.825150000 \\
$\mathrm{H}$ & -3.741512000 & 4.021833000 & 16.728245000 \\
$\mathrm{H}$ & -5.056543000 & 2.979256000 & 17.312315000 \\
$\mathrm{H}$ & -5.386839000 & 4.281360000 & 16.133965000 \\
$\mathrm{H}$ & -0.269148000 & 7.410820000 & 13.501716000 \\
$\mathrm{H}$ & -0.658264000 & 7.122998000 & 15.200452000 \\
$\mathrm{H}$ & -1.960018000 & 7.503279000 & 14.042446000 \\
$\mathrm{H}$ & -6.476210000 & 2.549282000 & 14.592130000 \\
$\mathrm{H}$ & -6.114267000 & 1.278314000 & 15.792099000 \\
$\mathrm{H}$ & -5.571590000 & 1.106110000 & 14.109106000 \\
$\mathrm{H}$ & -4.381639000 & 9.896275000 & 11.613425000 \\
$\mathrm{H}$ & -5.547762000 & 2.844402000 & 10.071487000 \\
$\mathrm{H}$ & -5.220151000 & 1.107393000 & 9.801503000 \\
$\mathrm{H}$ & -4.406514000 & 2.328270000 & 8.816622000 \\
$\mathrm{H}$ & -8.362816000 & 4.371217000 & 12.437296000 \\
$\mathrm{H}$ & -9.004859000 & 5.121876000 & 13.907707000 \\
$\mathrm{H}$ & -7.245393000 & 4.944827000 & 13.674332000 \\
$\mathrm{H}$ & -3.142808000 & 0.837966000 & 14.834572000 \\
$\mathrm{H}$ & -3.676431000 & 0.942676000 & 16.535825000 \\
\hline & -2.402257000 & 2.020124000 & 15.901424000 \\
\hline
\end{tabular}




\begin{tabular}{|c|c|c|c|}
\hline $\mathrm{H}$ & -3.192486000 & 9.296855000 & 8.854428000 \\
\hline $\mathrm{H}$ & -9.495292000 & 7.838510000 & 11.365030000 \\
\hline $\mathrm{H}$ & -10.342739000 & 6.708550000 & 12.448683000 \\
\hline $\mathrm{H}$ & -9.616767000 & 6.124842000 & 10.935522000 \\
\hline $\mathrm{H}$ & -6.302431000 & 11.067636000 & 14.022432000 \\
\hline $\mathrm{H}$ & -6.440947000 & 11.048682000 & 15.803913000 \\
\hline $\mathrm{H}$ & -7.484561000 & 10.017730000 & 14.786431000 \\
\hline $\mathrm{H}$ & -0.071326000 & 3.632627000 & 13.908561000 \\
\hline $\mathrm{H}$ & 0.576824000 & 4.865439000 & 15.018398000 \\
\hline $\mathrm{H}$ & 0.825687000 & 5.024655000 & 13.263906000 \\
\hline $\mathrm{H}$ & -2.032683000 & 1.472408000 & 9.574808000 \\
\hline $\mathrm{H}$ & -2.904054000 & 0.155088000 & 10.393183000 \\
\hline $\mathrm{H}$ & -1.765763000 & 1.177324000 & 11.303471000 \\
\hline $\mathrm{H}$ & -5.700622000 & 10.122132000 & 8.866017000 \\
\hline $\mathrm{H}$ & -5.136177000 & 11.499784000 & 9.840370000 \\
\hline $\mathrm{H}$ & -6.454706000 & 10.462320000 & 10.435773000 \\
\hline $\mathrm{H}$ & -6.725041000 & 7.983682000 & 16.118118000 \\
\hline $\mathrm{H}$ & -5.640296000 & 8.976962000 & 17.116334000 \\
\hline $\mathrm{H}$ & -5.004653000 & 7.581795000 & 16.197637000 \\
\hline $\mathrm{H}$ & -3.279193000 & 9.129629000 & 15.133858000 \\
\hline $\mathrm{H}$ & -3.955067000 & 10.511037000 & 16.035348000 \\
\hline $\mathrm{H}$ & -3.803859000 & 10.580861000 & 14.266177000 \\
\hline $\mathrm{H}$ & -7.433886000 & 4.911539000 & 10.393922000 \\
\hline $\mathrm{H}$ & -1.193156000 & 6.999024000 & 11.550741000 \\
\hline $\mathrm{H}$ & -2.121077000 & 6.383613000 & 9.334535000 \\
\hline $\mathrm{H}$ & -5.677396000 & 5.392542000 & 8.649829000 \\
\hline $\mathrm{H}$ & -3.249969000 & 4.185899000 & 8.992467000 \\
\hline
\end{tabular}


$\begin{array}{llll}\mathrm{H} & -4.358076000 & 7.428932000 & 8.737393000\end{array}$

\section{Complex 3- formal U(IV)}

$\begin{array}{lrll}\mathrm{U} & -4.416936000 & 5.877179000 & 12.094364000 \\ \mathrm{O} & -4.774898000 & 4.238671000 & 13.624825000 \\ \mathrm{O} & -4.488691000 & 7.626544000 & 13.513366000 \\ \mathrm{~N} & -2.885884000 & 2.942369000 & 13.412061000 \\ \mathrm{~N} & -6.255431000 & 8.824129000 & 12.647925000 \\ \mathrm{C} & -5.300469000 & 8.805203000 & 16.029385000 \\ \mathrm{C} & -6.270397000 & 10.692978000 & 14.683707000 \\ \mathrm{C} & -3.777412000 & 9.447937000 & 9.112436000 \\ \mathrm{C} & -3.886770000 & 2.212078000 & 9.242896000 \\ \mathrm{C} & -5.911920000 & 1.708763000 & 14.586733000 \\ \mathrm{C} & -4.842362000 & 3.174389000 & 16.320679000 \\ \mathrm{C} & -8.621078000 & 5.204682000 & 13.188655000 \\ \mathrm{C} & -1.002694000 & 6.652227000 & 14.712459000 \\ \mathrm{C} & -2.128154000 & 1.285729000 & 10.790362000 \\ \mathrm{C} & -3.291470000 & 2.283291000 & 10.648379000 \\ \mathrm{C} & -0.102018000 & 4.307823000 & 14.436323000 \\ \mathrm{C} & -1.327293000 & 5.223745000 & 14.275544000 \\ \mathrm{C} & -2.816769000 & 3.664490000 & 11.074040000 \\ \mathrm{C} & -2.699469000 & 4.731131000 & 10.169879000 \\ \mathrm{C} & -2.174631000 & 5.985777000 & 10.588948000 \\ \mathrm{C} & -1.672052000 & 6.116398000 & 11.902681000 \\ \mathrm{C} & -1.865299000 & 5.114108000 & 12.857207000 \\ \mathrm{C} & -2.524896000 & 3.895668000 & 12.443513000\end{array}$




\begin{tabular}{lrrr}
$\mathrm{C}$ & -3.601195000 & 1.183435000 & 15.417800000 \\
$\mathrm{C}$ & -4.580797000 & 2.308810000 & 15.074999000 \\
$\mathrm{C}$ & -4.024811000 & 3.203915000 & 13.972427000 \\
$\mathrm{C}$ & -6.006346000 & 10.370580000 & 9.841356000 \\
$\mathrm{C}$ & -4.859304000 & 9.406165000 & 10.190797000 \\
$\mathrm{C}$ & -9.275418000 & 7.538165000 & 12.468831000 \\
$\mathrm{C}$ & -8.114328000 & 6.608723000 & 12.860356000 \\
$\mathrm{C}$ & -3.798133000 & 10.256530000 & 14.636008000 \\
$\mathrm{C}$ & -5.191691000 & 9.607111000 & 14.720047000 \\
$\mathrm{C}$ & -5.344759000 & 8.644170000 & 13.547771000 \\
$\mathrm{C}$ & -5.225124000 & 6.943236000 & 9.617041000 \\
$\mathrm{C}$ & -5.817862000 & 5.671254000 & 9.884232000 \\
$\mathrm{C}$ & -6.829453000 & 5.590225000 & 10.896188000 \\
$\mathrm{C}$ & -7.047057000 & 6.651426000 & 11.777163000 \\
$\mathrm{C}$ & -6.232357000 & 7.825560000 & 11.645509000 \\
$\mathrm{C}$ & -5.429960000 & 8.024462000 & 10.464802000 \\
$\mathrm{H}$ & -4.605939000 & 7.059696000 & 8.734139000 \\
$\mathrm{H}$ & -2.954944000 & 4.586593000 & 9.127037000 \\
$\mathrm{H}$ & -5.718359000 & 4.872856000 & 9.159211000 \\
$\mathrm{H}$ & -2.008206000 & 6.772747000 & 9.863205000 \\
$\mathrm{H}$ & -1.183297000 & 7.042703000 & 12.188877000 \\
$\mathrm{H}$ & -7.418787000 & 4.683448000 & 10.985048000 \\
$\mathrm{H}$ & -3.691425000 & 10.844739000 & 13.717852000 \\
$\mathrm{H}$ & -3.646546000 & 10.931332000 & 15.485657000 \\
\hline & -3.008689000 & 9.500737000 & 14.653608000 \\
\hline & -5.152033000 & 9.468143000 & 16.888937000
\end{tabular}




\begin{tabular}{crrr}
$\mathrm{H}$ & -6.289651000 & 8.344890000 & 16.128627000 \\
$\mathrm{H}$ & -6.740440000 & 10.404346000 & 10.649458000 \\
$\mathrm{H}$ & -5.618461000 & 11.382948000 & 9.683941000 \\
$\mathrm{H}$ & -6.510329000 & 10.053745000 & 8.921281000 \\
$\mathrm{H}$ & -1.754053000 & 1.271776000 & 11.816445000 \\
$\mathrm{H}$ & -2.460996000 & 0.275232000 & 10.529683000 \\
$\mathrm{H}$ & -1.305001000 & 1.554201000 & 10.118563000 \\
$\mathrm{H}$ & 0.710478000 & 4.629521000 & 13.774948000 \\
$\mathrm{H}$ & 0.267326000 & 4.342204000 & 15.467133000 \\
$\mathrm{H}$ & -0.356538000 & 3.272236000 & 14.197410000 \\
$\mathrm{H}$ & -7.272073000 & 10.257593000 & 14.733116000 \\
$\mathrm{H}$ & -6.144289000 & 11.371090000 & 15.535548000 \\
$\mathrm{H}$ & -6.213770000 & 11.278044000 & 13.762150000 \\
$\mathrm{H}$ & -9.751774000 & 7.193617000 & 11.544062000 \\
$\mathrm{H}$ & -10.035734000 & 7.551426000 & 13.257348000 \\
$\mathrm{H}$ & -8.918428000 & 8.559890000 & 12.318007000 \\
$\mathrm{H}$ & -4.174976000 & 9.181563000 & 8.126441000 \\
$\mathrm{H}$ & -3.371971000 & 10.461494000 & 9.033132000 \\
$\mathrm{H}$ & -2.945999000 & 8.773520000 & 9.339400000 \\
$\mathrm{H}$ & -2.643470000 & 1.582944000 & 15.762062000 \\
$\mathrm{H}$ & -4.020337000 & 0.554838000 & 16.211697000 \\
$\mathrm{H}$ & -3.399458000 & 0.554113000 & 14.547070000 \\
$\mathrm{H}$ & -7.800596000 & 4.531433000 & 13.456105000 \\
$\mathrm{H}$ & -9.311736000 & 5.249589000 & 14.036713000 \\
$\mathrm{H}$ & -9.170929000 & 4.763260000 & 12.349442000 \\
\hline & -3.139432000 & 2.434945000 & 8.472842000 \\
\hline
\end{tabular}




$\begin{array}{llll}\mathrm{H} & -4.726324000 & 2.901418000 & 9.114422000 \\ \mathrm{H} & -4.417880000 & 9.764299000 & 11.129542000 \\ \mathrm{H} & -5.761315000 & 1.080933000 & 13.701539000 \\ \mathrm{H} & -6.350779000 & 1.082413000 & 15.371116000 \\ \mathrm{H} & -6.628691000 & 2.494070000 & 14.333512000 \\ \mathrm{H} & -1.865264000 & 7.315074000 & 14.594263000 \\ \mathrm{H} & -0.713783000 & 6.657450000 & 15.768188000 \\ \mathrm{H} & -0.160941000 & 7.071845000 & 14.149171000 \\ \mathrm{H} & -5.525437000 & 3.995880000 & 16.090729000 \\ \mathrm{H} & -5.286200000 & 2.564088000 & 17.114969000 \\ \mathrm{H} & -3.910976000 & 3.601508000 & 16.708400000 \\ \mathrm{H} & -4.065016000 & 1.974895000 & 11.363468000 \\ \mathrm{H} & -7.665886000 & 7.026249000 & 13.770309000 \\ \mathrm{H} & -2.105640000 & 4.841660000 & 14.946654000\end{array}$

\section{Complex 3- one arene bound}

$\begin{array}{llll}\mathrm{C} & -0.595477000 & 2.379013000 & 19.754316000 \\ \mathrm{C} & -1.403862000 & 3.494327000 & 19.914950000 \\ \mathrm{C} & -2.870447000 & 3.448334000 & 19.619517000 \\ \mathrm{C} & -3.385717000 & 2.082972000 & 19.566451000 \\ \mathrm{C} & -2.577282000 & 1.007799000 & 19.289895000 \\ \mathrm{C} & -1.138494000 & 1.164513000 & 19.143209000 \\ \mathrm{U} & -1.873063000 & 2.910770000 & 17.426413000 \\ \mathrm{O} & -0.754002000 & 4.874090000 & 17.818173000 \\ \mathrm{C} & -0.561482000 & 5.385277000 & 19.022725000 \\ \mathrm{~N} & -0.831713000 & 4.778106000 & 20.135183000 \\ \mathrm{C} & -3.752056000 & 4.550225000 & 20.195023000\end{array}$




$\begin{array}{lrll}\mathrm{C} & -3.963285000 & 4.384137000 & 21.709230000 \\ \mathrm{C} & 0.892959000 & 2.446975000 & 20.059064000 \\ \mathrm{C} & 1.246353000 & 1.485967000 & 21.204433000 \\ \mathrm{O} & -3.232171000 & 2.639106000 & 15.606452000 \\ \mathrm{C} & -3.874095000 & 2.746062000 & 14.475538000 \\ \mathrm{C} & -4.873453000 & 1.574843000 & 14.258279000 \\ \mathrm{C} & -4.065147000 & 0.263861000 & 14.265775000 \\ \mathrm{~N} & -3.624933000 & 3.745588000 & 13.699730000 \\ \mathrm{C} & -4.126513000 & 4.118985000 & 12.465696000 \\ \mathrm{C} & -3.441829000 & 3.739519000 & 11.278910000 \\ \mathrm{C} & -3.885337000 & 4.235447000 & 10.052084000 \\ \mathrm{C} & -4.968152000 & 5.106227000 & 9.967197000 \\ \mathrm{C} & -5.612563000 & 5.503894000 & 11.135552000 \\ \mathrm{C} & -5.209787000 & 5.036490000 & 12.387291000 \\ \mathrm{C} & -2.213074000 & 2.850410000 & 11.383414000 \\ \mathrm{C} & -0.997331000 & 3.674855000 & 11.837479000 \\ \mathrm{C} & -5.865728000 & 5.521727000 & 13.669954000 \\ \mathrm{C} & -4.995262000 & 6.597939000 & 14.338777000 \\ \mathrm{C} & -5.848719000 & 1.563240000 & 15.450326000 \\ \mathrm{C} & -5.685704000 & 1.643363000 & 12.961041000 \\ \mathrm{C} & -7.302382000 & 6.018651000 & 13.493403000 \\ \mathrm{C} & -1.890602000 & 2.068065000 & 10.108144000 \\ \mathrm{C} & 0.035531000 & 6.795921000 & 19.041072000 \\ \mathrm{C} & 0.250228000 & 7.290829000 & 20.472900000 \\ \mathrm{C} & 1.378472000 & 6.763408000 & 18.290879000 \\ \mathrm{C} & -0.929802000 & 7.737994000 & 18.300731000 \\ & -5.094792000 & 4.676919000 & 19.469735000\end{array}$




\begin{tabular}{lrrr}
$\mathrm{C}$ & 1.782384000 & 2.182522000 & 18.837990000 \\
$\mathrm{H}$ & -5.898067000 & 4.668876000 & 14.359325000 \\
$\mathrm{H}$ & 1.096387000 & 3.464978000 & 20.407802000 \\
$\mathrm{H}$ & -2.409751000 & 2.116751000 & 12.174908000 \\
$\mathrm{H}$ & -3.368876000 & 0.222458000 & 13.420456000 \\
$\mathrm{H}$ & -4.742055000 & -0.595432000 & 14.183628000 \\
$\mathrm{H}$ & -3.487004000 & 0.166990000 & 15.187677000 \\
$\mathrm{H}$ & -7.345659000 & 6.948125000 & 12.913076000 \\
$\mathrm{H}$ & -7.748039000 & 6.231207000 & 14.471495000 \\
$\mathrm{H}$ & -7.930942000 & 5.277476000 & 12.987408000 \\
$\mathrm{H}$ & -5.308814000 & 1.474103000 & 16.395464000 \\
$\mathrm{H}$ & -6.541237000 & 0.717145000 & 15.360310000 \\
$\mathrm{H}$ & -6.446158000 & 2.481402000 & 15.483159000 \\
$\mathrm{H}$ & -3.211931000 & 5.492280000 & 20.047097000 \\
$\mathrm{H}$ & -2.753765000 & 1.494944000 & 9.751889000 \\
$\mathrm{H}$ & -1.070837000 & 1.365803000 & 10.296307000 \\
$\mathrm{H}$ & -1.566677000 & 2.727985000 & 9.294435000 \\
$\mathrm{H}$ & 1.643857000 & 1.167829000 & 18.448826000 \\
$\mathrm{H}$ & 2.842072000 & 2.298619000 & 19.100294000 \\
$\mathrm{H}$ & 1.556919000 & 2.881873000 & 18.025518000 \\
$\mathrm{H}$ & -6.302539000 & 2.543829000 & 12.904515000 \\
$\mathrm{H}$ & -6.355164000 & 0.774941000 & 12.915795000 \\
$\mathrm{H}$ & -5.051651000 & 1.623859000 & 12.071269000 \\
$\mathrm{H}$ & -4.938450000 & 4.820461000 & 18.394793000 \\
\hline & -5.669653000 & 5.529067000 & 19.853857000 \\
\hline & -5.718240000 & 3.783802000 & 19.602132000 \\
\hline
\end{tabular}




\begin{tabular}{lrll}
$\mathrm{H}$ & 2.306017000 & 1.574108000 & 21.476751000 \\
$\mathrm{H}$ & 1.059220000 & 0.443395000 & 20.921789000 \\
$\mathrm{H}$ & -0.691853000 & 7.305158000 & 21.027216000 \\
$\mathrm{H}$ & 0.670675000 & 8.305069000 & 20.462259000 \\
$\mathrm{H}$ & 0.933580000 & 6.633542000 & 21.017628000 \\
$\mathrm{H}$ & -3.987056000 & 6.214831000 & 14.515285000 \\
$\mathrm{H}$ & -5.419992000 & 6.903947000 & 15.302195000 \\
$\mathrm{H}$ & -4.923979000 & 7.485684000 & 13.698942000 \\
$\mathrm{H}$ & -0.742638000 & 4.429493000 & 11.083727000 \\
$\mathrm{H}$ & -0.121370000 & 3.032368000 & 11.987767000 \\
$\mathrm{H}$ & -1.214965000 & 4.184512000 & 12.779624000 \\
$\mathrm{H}$ & -4.479462000 & 3.441133000 & 21.929166000 \\
$\mathrm{H}$ & -4.563835000 & 5.202832000 & 22.128718000 \\
$\mathrm{H}$ & -2.999231000 & 4.367437000 & 22.227024000 \\
$\mathrm{H}$ & 2.097308000 & 6.113273000 & 18.802184000 \\
$\mathrm{H}$ & 1.811287000 & 7.770095000 & 18.235732000 \\
$\mathrm{H}$ & 1.240674000 & 6.384473000 & 17.274961000 \\
$\mathrm{H}$ & -1.116937000 & 7.376003000 & 17.286508000 \\
$\mathrm{H}$ & -0.508904000 & 8.749589000 & 18.241590000 \\
$\mathrm{H}$ & -1.891614000 & 7.801575000 & 18.821653000 \\
$\mathrm{H}$ & -0.528433000 & 0.265853000 & 19.144050000 \\
$\mathrm{H}$ & -6.449516000 & 6.194264000 & 11.069929000 \\
$\mathrm{H}$ & -5.301166000 & 5.477866000 & 9.001248000 \\
$\mathrm{H}$ & -3.025794000 & 0.031672000 & 19.108964000 \\
& -3.373894000 & 3.935725000 & 9.141019000 \\
\hline & -4.464536000 & 1.934597000 & 19.586600000
\end{tabular}




\section{Complex 3- both arenes unbound}

\begin{tabular}{|c|c|c|c|}
\hline & -1.679766000 & 3.281657000 & 17.284226000 \\
\hline & -2.924709000 & 2.849037000 & 15.517907000 \\
\hline & -0.921178000 & .999246000 & 8.453431000 \\
\hline & -3.822888000 & .099289000 & 3.894139000 \\
\hline & 0.380622000 & 883333000 & 18.796325000 \\
\hline & -1.876380000 & 8.336569000 & 15.938392000 \\
\hline & 3.451706000 & 3.943658000 & 17.870 \\
\hline & -0.868316000 & 4.811316000 & 21.344609000 \\
\hline & -2.607751000 & 6.369 & 20.4 \\
\hline & -0.465282000 & 000 & 21.3 \\
\hline & -1.09 & 000 & 0000 \\
\hline & 66000 & 4.3368 & 10.1 \\
\hline & -8.130241000 & 4.506796000 & 541000 \\
\hline & -4.710569000 & 000 & 12.48 \\
\hline & -4.832873000 & 8000 & 14.8 \\
\hline & -6.311608000 & 5.813143000 & 15.039012000 \\
\hline & -6.620032000 & 4.664194000 & 14.065466000 \\
\hline & -1.476766000 & 7000 & 12.362972000 \\
\hline & -2.202366000 & 789000 & 11.580534000 \\
\hline & -5.842359000 & 4.847243000 & 12.771953000 \\
\hline & -6.436485000 & 5.381698000 & 11.627495000 \\
\hline & -5.704362000 & 5.606825000 & 10.465353000 \\
\hline & -4.344364000 & 5.309358000 & 10.449574000 \\
\hline & -3.700606000 & 4.774614000 & 11.566480000 \\
\hline & -4.463046000 & 4.510500000 & 12.73593900 \\
\hline & .658069000 & 000 & 13.637444000 \\
\hline
\end{tabular}




\begin{tabular}{lrrr}
$\mathrm{C}$ & -3.955763000 & 1.537566000 & 13.821487000 \\
$\mathrm{C}$ & -3.578114000 & 2.935644000 & 14.378448000 \\
$\mathrm{C}$ & -0.266214000 & 10.160096000 & 16.632705000 \\
$\mathrm{C}$ & -0.657685000 & 8.685626000 & 16.802778000 \\
$\mathrm{C}$ & 3.443825000 & 5.966317000 & 19.381472000 \\
$\mathrm{C}$ & 2.634340000 & 5.134927000 & 18.373183000 \\
$\mathrm{C}$ & -0.483830000 & 6.007609000 & 19.174795000 \\
$\mathrm{C}$ & 1.168093000 & 7.793010000 & 15.297351000 \\
$\mathrm{C}$ & 2.257704000 & 6.973116000 & 15.031817000 \\
$\mathrm{C}$ & 2.714923000 & 6.105621000 & 16.021363000 \\
$\mathrm{C}$ & 2.093738000 & 6.029702000 & 17.268641000 \\
$\mathrm{C}$ & 0.967146000 & 6.854073000 & 17.521733000 \\
$\mathrm{C}$ & 0.514799000 & 7.756598000 & 16.532489000 \\
$\mathrm{H}$ & 3.570008000 & 5.468805000 & 15.813387000 \\
$\mathrm{H}$ & -3.771602000 & 5.498598000 & 9.545659000 \\
$\mathrm{H}$ & 2.750646000 & 7.008726000 & 14.063420000 \\
$\mathrm{H}$ & -6.187105000 & 6.018882000 & 9.582636000 \\
$\mathrm{H}$ & -7.495167000 & 5.627114000 & 11.642480000 \\
$\mathrm{H}$ & 0.810549000 & 8.475484000 & 14.528966000 \\
$\mathrm{H}$ & 0.200977000 & 4.600583000 & 21.459542000 \\
$\mathrm{H}$ & -1.309832000 & 4.878431000 & 22.346334000 \\
$\mathrm{H}$ & -1.326486000 & 3.965049000 & 20.824139000 \\
$\mathrm{H}$ & -3.080118000 & 5.564031000 & 19.857442000 \\
$\mathrm{H}$ & -3.083267000 & 6.415684000 & 21.415947000 \\
\hline & -2.804306000 & 7.315728000 & 19.912685000 \\
\hline & 2.839110000 & 6.788797000 & 19.773252000 \\
$\mathrm{H}$ & 3.775598000 & 5.347043000 & 20.224264000
\end{tabular}




\begin{tabular}{|c|c|c|c|}
\hline $\mathrm{H}$ & 4.334337000 & 6.391592000 & 18.902726000 \\
\hline $\mathrm{H}$ & -1.889740000 & 5.710577000 & 13.370734000 \\
\hline $\mathrm{H}$ & -0.406673000 & 5.403257000 & 12.453905000 \\
\hline $\mathrm{H}$ & -1.589350000 & 6.585793000 & 11.853302000 \\
\hline $\mathrm{H}$ & -6.648654000 & 6.769579000 & 14.621771000 \\
\hline $\mathrm{H}$ & -6.819150000 & 5.660703000 & 15.999087000 \\
\hline $\mathrm{H}$ & -5.236598000 & 5.875240000 & 15.226071000 \\
\hline $\mathrm{H}$ & -0.602238000 & 8.234668000 & 20.834254000 \\
\hline $\mathrm{H}$ & -0.927086000 & 7.359371000 & 22.350080000 \\
\hline $\mathrm{H}$ & 0.610701000 & 7.136563000 & 21.485250000 \\
\hline $\mathrm{H}$ & 0.015626000 & 10.386657000 & 15.597655000 \\
\hline $\mathrm{H}$ & -1.105087000 & 10.816049000 & 16.895655000 \\
\hline $\mathrm{H}$ & 0.583140000 & 10.418535000 & 17.273452000 \\
\hline $\mathrm{H}$ & 4.392250000 & 4.257784000 & 17.401473000 \\
\hline $\mathrm{H}$ & 3.712766000 & 3.288661000 & 18.709176000 \\
\hline $\mathrm{H}$ & 2.885324000 & 3.351168000 & 17.144513000 \\
\hline $\mathrm{H}$ & -4.127329000 & 2.029264000 & 11.689642000 \\
\hline $\mathrm{H}$ & -4.930293000 & 0.532779000 & 12.187595000 \\
\hline $\mathrm{H}$ & -5.659776000 & 2.101729000 & 12.558328000 \\
\hline $\mathrm{H}$ & -2.184797000 & 7.298241000 & 16.092863000 \\
\hline $\mathrm{H}$ & -2.727226000 & 8.984763000 & 16.181750000 \\
\hline $\mathrm{H}$ & -1.658194000 & 8.460958000 & 14.871401000 \\
\hline $\mathrm{H}$ & -1.599543000 & 5.269258000 & 9.616086000 \\
\hline $\mathrm{H}$ & -0.532479000 & 4.038737000 & 10.288662000 \\
\hline $\mathrm{H}$ & -2.101441000 & 3.569486000 & 9.607879000 \\
\hline $\mathrm{H}$ & 1.768468000 & 4.723211000 & 18.904100000 \\
\hline $\mathrm{H}$ & -5.777166000 & 1.367667000 & 15.027210000 \\
\hline
\end{tabular}




$\begin{array}{llll}\mathrm{H} & -5.073206000 & -0.182500000 & 14.536280000 \\ \mathrm{H} & -4.316866000 & 0.769144000 & 15.834666000 \\ \mathrm{H} & -8.369890000 & 3.715371000 & 13.154806000 \\ \mathrm{H} & -8.604547000 & 4.253528000 & 14.828150000 \\ \mathrm{H} & -8.596350000 & 5.434271000 & 13.520212000 \\ \mathrm{H} & -2.108000000 & 0.645568000 & 14.577841000 \\ \mathrm{H} & -2.897839000 & -0.280814000 & 13.282716000 \\ \mathrm{H} & -1.999221000 & 1.196672000 & 12.897133000 \\ \mathrm{H} & -2.039234000 & 3.579463000 & 12.130816000 \\ \mathrm{H} & -0.937073000 & 8.541098000 & 17.851256000 \\ \mathrm{H} & -6.253918000 & 3.743726000 & 14.536786000\end{array}$

\section{Complex 5- Singlet Th(IV) with one arene bound}

$\begin{array}{llll}\text { Th } & 7.65724 & 12.98919 & 8.08882 \\ \text { O } & 8.81271 & 11.02001 & 7.46073 \\ \text { O } & 8.21052 & 14.47721 & 6.26446 \\ \text { O } & 5.58043 & 12.79385 & 6.99181 \\ \text { O } & 6.70280 & 11.12835 & 9.72452 \\ \text { N } & 10.04445 & 9.06511 & 7.12814 \\ \text { N } & 3.34351 & 12.33924 & 6.52149 \\ \text { N } & 8.78301 & 16.31636 & 7.53364 \\ \text { C } & 8.53890 & 15.44099 & 8.61374 \\ \text { C } & 7.35554 & 15.46394 & 9.32684 \\ \text { C } & 9.54803 & 10.19671 & 6.75030 \\ \text { C } & 9.42437 & 13.71605 & 10.12867 \\ \text { C } & 7.02783 & 14.33585 & 10.19404 \\ \text { C } & 8.19515 & 13.62527 & 10.73071\end{array}$




$\begin{array}{cccc}\mathrm{C} & 8.66445 & 15.70710 & 6.39318 \\ \mathrm{C} & 9.61912 & 14.40852 & 8.86864 \\ \mathrm{C} & 4.46447 & 12.94439 & 6.31408 \\ \mathrm{C} & 3.07002 & 11.35173 & 7.46036 \\ \mathrm{C} & 9.92130 & 8.44304 & 8.36849 \\ \mathrm{C} & 3.39162 & 9.99676 & 7.18695 \\ \mathrm{C} & 9.08033 & 7.30088 & 8.47352 \\ \mathrm{C} & 5.38840 & 11.20420 & 10.33092 \\ \mathrm{H} & 4.65931 & 10.88263 & 9.58578 \\ \mathrm{H} & 5.19621 & 12.24702 & 10.59320 \\ \mathrm{C} & 2.29042 & 11.67670 & 8.60118 \\ \mathrm{C} & 6.35169 & 16.58166 & 9.08238 \\ \mathrm{H} & 6.41180 & 16.84736 & 8.02036 \\ \mathrm{C} & 11.03514 & 14.81549 & 8.45907 \\ \mathrm{H} & 11.00286 & 15.08561 & 7.39693 \\ \mathrm{C} & 10.75041 & 8.80100 & 9.46500 \\ \mathrm{C} & 1.89119 & 10.65321 & 9.46313 \\ \mathrm{H} & 1.30115 & 10.89614 & 10.34301 \\ \mathrm{C} & 7.49639 & 10.12756 & 10.39487 \\ \mathrm{H} & 8.17049 & 10.62853 & 11.10222 \\ \mathrm{H} & 8.09320 & 9.61340 & 9.64360 \\ \mathrm{C} & 9.06329 & 16.44994 & 5.10791 \\ \mathrm{C} & 9.84541 & 10.63000 & 5.29865 \\ \mathrm{C} & 11.77253 & 9.91276 & 9.30544 \\ \mathrm{H} & 11.27698 & 10.73266 & 8.77361 \\ \mathrm{C} & 2.23687 & 9.32592 & 9.22129 \\ \mathrm{H} & 1.92218 & 8.54241 & 9.90632\end{array}$




$\begin{array}{lccc}\mathrm{C} & 8.33334 & 6.80181 & 7.24724 \\ \mathrm{H} & 7.96922 & 7.68219 & 6.70467 \\ \mathrm{C} & 5.42780 & 10.26536 & 11.53305 \\ \mathrm{H} & 4.44713 & 9.82282 & 11.72656 \\ \mathrm{H} & 5.74931 & 10.79907 & 12.43554 \\ \mathrm{C} & 10.70807 & 11.90277 & 5.32501 \\ \mathrm{H} & 10.20867 & 12.72587 & 5.84280 \\ \mathrm{H} & 10.91809 & 12.23175 & 4.30049 \\ \mathrm{H} & 11.66720 & 11.71109 & 5.81820 \\ \mathrm{C} & 12.05365 & 13.68473 & 8.59586 \\ \mathrm{H} & 12.23260 & 13.42539 & 9.64573 \\ \mathrm{H} & 13.02029 & 13.98405 & 8.17270 \\ \mathrm{H} & 11.71574 & 12.78443 & 8.07574 \\ \mathrm{C} & 2.97601 & 9.00991 & 8.08388 \\ \mathrm{H} & 3.22912 & 7.97142 & 7.88855 \\ \mathrm{C} & 4.09237 & 9.64806 & 5.88416 \\ \mathrm{H} & 4.83358 & 10.43227 & 5.69480 \\ \mathrm{C} & 4.74882 & 15.35634 & 5.71607 \\ \mathrm{H} & 3.95577 & 15.64975 & 6.41246 \\ \mathrm{H} & 4.77163 & 16.09232 & 4.90448 \\ \mathrm{H} & 5.70777 & 15.39861 & 6.23646 \\ \mathrm{C} & 1.85920 & 13.11740 & 8.82045 \\ \mathrm{H} & 2.67927 & 13.75268 & 8.46700 \\ \mathrm{H} & 8.51879 & 10.92091 & 4.57934 \\ \mathrm{H} & 7.87799 & 10.03240 & 4.55642 \\ & 7.71150 & 11.22491 & 3.54397 \\ \mathrm{H} & 7.96260 & 11.72900 & 5.05898\end{array}$




\begin{tabular}{cccc}
$\mathrm{C}$ & 5.61175 & 13.56447 & 4.17575 \\
$\mathrm{H}$ & 6.59037 & 13.64417 & 4.65415 \\
$\mathrm{H}$ & 5.60007 & 14.23355 & 3.30666 \\
$\mathrm{H}$ & 5.47613 & 12.54149 & 3.80624 \\
$\mathrm{C}$ & 6.48885 & 9.24668 & 11.11461 \\
$\mathrm{H}$ & 6.93860 & 8.70512 & 11.95095 \\
$\mathrm{H}$ & 6.06490 & 8.51365 & 10.42007 \\
$\mathrm{C}$ & 9.01232 & 6.61401 & 9.68731 \\
$\mathrm{H}$ & 8.35416 & 5.75444 & 9.77785 \\
$\mathrm{C}$ & 11.52662 & 16.05609 & 9.22433 \\
$\mathrm{H}$ & 10.84928 & 16.89838 & 9.05923 \\
$\mathrm{H}$ & 12.53308 & 16.35604 & 8.90133 \\
$\mathrm{H}$ & 11.56601 & 15.85234 & 10.30196 \\
$\mathrm{C}$ & 12.94724 & 9.43504 & 8.43508 \\
$\mathrm{H}$ & 13.49703 & 8.63257 & 8.94180 \\
$\mathrm{H}$ & 13.64714 & 10.25660 & 8.24136 \\
$\mathrm{H}$ & 12.58787 & 9.05279 & 7.47634 \\
$\mathrm{C}$ & 3.08283 & 9.67215 & 4.72425 \\
$\mathrm{H}$ & 2.33299 & 8.88205 & 4.85263 \\
$\mathrm{H}$ & 3.58623 & 9.50842 & 3.76356 \\
$\mathrm{H}$ & 2.56475 & 10.63372 & 4.68431 \\
$\mathrm{C}$ & 3.15465 & 13.96687 & 4.39174 \\
$\mathrm{H}$ & 2.93119 & 12.98936 & 3.95556 \\
$\mathrm{H}$ & 3.20517 & 14.70411 & 3.58044 \\
$\mathrm{C}$ & 2.32370 & 14.23098 & 5.05029 \\
& 4.48684 & 13.95274 & 5.14870 \\
\hline
\end{tabular}




\begin{tabular}{|c|c|c|c|}
\hline 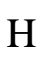 & 5.54441 & 8.27080 & 6.74783 \\
\hline & 5.41150 & 8.18876 & 4.98424 \\
\hline & 4.16030 & 7.46211 & 5.98986 \\
\hline & 10.64964 & 8.07635 & 10.65534 \\
\hline & 11.26675 & 8.35831 & 11.50338 \\
\hline & 9.80249 & 17.75009 & 5.44183 \\
\hline & 9.17989 & 18.40894 & 6.05159 \\
\hline & 10.07508 & 18.27333 & 4.51593 \\
\hline & 10.71550 & 17.55114 & 6.01030 \\
\hline & 12.29676 & 10.47472 & 10.62791 \\
\hline $\mathrm{H}$ & 11.48368 & 10.80837 & 11.28134 \\
\hline $\mathrm{H}$ & 12.94884 & 11.33240 & 10.43675 \\
\hline U & 12.89094 & 9.73444 & 11.17735 \\
\hline$C$ & 7.80300 & 16.78290 & 4.29346 \\
\hline & 7.25281 & 15.87591 & 4.03531 \\
\hline & 8.07851 & 17.29555 & 3.36310 \\
\hline & 7.13424 & 17.44124 & 4.85791 \\
\hline & 9.77607 & 7.00133 & 10.78381 \\
\hline $\mathbf{H}$ & 9.70655 & 6.45800 & 11.72303 \\
\hline C & 4.90029 & 16.21611 & 9.39966 \\
\hline H & 4.59468 & 15.29613 & 8.89269 \\
\hline 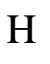 & 4.22914 & 17.02125 & 9.07879 \\
\hline 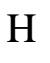 & 4.74558 & 16.07271 & 10.47539 \\
\hline & 9.97325 & 15.54178 & 4.26641 \\
\hline 1 & 10.89109 & 15.28967 & 4.80847 \\
\hline & 10.25890 & 16.04950 & 3.33674 \\
\hline & 9.46500 & 14.60835 & 4.01435 \\
\hline
\end{tabular}




$\begin{array}{cccc}\mathrm{C} & 10.59596 & 9.54031 & 4.52665 \\ \mathrm{H} & 11.54924 & 9.30011 & 5.00390 \\ \mathrm{H} & 10.79535 & 9.88630 & 3.50455 \\ \mathrm{H} & 10.01372 & 8.61649 & 4.47069 \\ \mathrm{C} & 6.78333 & 17.82637 & 9.87450 \\ \mathrm{H} & 6.80684 & 17.61246 & 10.94979 \\ \mathrm{H} & 6.08665 & 18.65847 & 9.70930 \\ \mathrm{H} & 7.78251 & 18.14492 & 9.56570 \\ \mathrm{C} & 9.30462 & 6.06128 & 6.31226 \\ \mathrm{H} & 10.14940 & 6.70419 & 6.05477 \\ \mathrm{H} & 8.80142 & 5.75763 & 5.38591 \\ \mathrm{H} & 9.69012 & 5.15804 & 6.80040 \\ \mathrm{C} & 7.12857 & 5.91298 & 7.56241 \\ \mathrm{H} & 7.43442 & 4.95161 & 7.99261 \\ \mathrm{H} & 6.57509 & 5.69184 & 6.64376 \\ \mathrm{H} & 6.43754 & 6.39132 & 8.26418 \\ \mathrm{C} & 1.59320 & 13.47965 & 10.28317 \\ \mathrm{H} & 0.70793 & 12.96714 & 10.67866 \\ \mathrm{H} & 1.40958 & 14.55565 & 10.37606 \\ \mathrm{H} & 2.44376 & 13.22688 & 10.92445 \\ \mathrm{C} & 0.63244 & 13.43770 & 7.95108 \\ \mathrm{H} & 0.84432 & 13.21839 & 6.90154 \\ \mathrm{H} & 0.35544 & 14.49573 & 8.03627 \\ \mathrm{H} & -0.22884 & 12.83491 & 8.26363 \\ \mathrm{H} & 8.06707 & 12.98699 & 11.60201 \\ \mathrm{H} & 10.24972 & 13.13565 & 10.53659 \\ \mathrm{H} & 6.16286 & 14.42264 & 10.84358\end{array}$




\section{Complex 5- Singlet Th(IV) with arenes unbound}
C $\quad 11.05584 \quad 7.45644 \quad 10.65391$
C $\quad 10.36267 \quad 6.80757 \quad 9.63606$
C $\quad 10.17539 \quad 7.41047 \quad 8.39068$
C $\quad 10.67659 \quad 8.72147 \quad 8.17710$
C $\quad 11.43805 \quad 9.36152 \quad 9.18652$
C $\quad \begin{array}{llll}11.60060 & 8.71393 & 10.41461\end{array}$
$\begin{array}{llll}\mathrm{N} & 10.54200 & 9.26607 & 6.89743\end{array}$
$\begin{array}{llll}\text { C } & 9.78550 & 10.25279 & 6.56328\end{array}$
C $\quad 9.75035 \quad 10.64380 \quad 5.07293$
C $\quad 10.76177 \quad 9.82297 \quad 4.26622$
$\begin{array}{llll}\text { C } & 9.51487 & 6.66609 & 7.23961\end{array}$
$\begin{array}{llll}\text { C } & 8.55642 & 5.55309 & 7.66959\end{array}$
$\begin{array}{llll}\text { C } & 12.13490 & 10.67873 & 8.88528\end{array}$
$\begin{array}{llll}\text { C } & 12.56100 & 11.46303 & 10.12629\end{array}$
$\begin{array}{llll}\text { O } & 9.01342 & 10.95150 & 7.37834\end{array}$
$\begin{array}{llll}\text { Th } & 7.46689 & 12.37958 & 8.22152\end{array}$
$\begin{array}{llll}\text { C } & 8.19822 & 14.91508 & 12.05437\end{array}$
C $\quad 8.02127 \quad 15.89941 \quad 11.05127$
C $\quad 6.94314 \quad 16.81733 \quad 11.13520$
C $\quad 6.01995 \quad 16.68103 \quad 12.17360$
C $\quad 6.15931 \quad 15.68704 \quad 13.13673$
$\begin{array}{llll}\text { C } & 7.25041 & 14.82737 & 13.07759\end{array}$
$\begin{array}{llll}\mathrm{N} & 8.98790 & 16.11355 & 10.05832\end{array}$
$\begin{array}{llll}\text { C } & 9.16065 & 15.39031 & 9.01234\end{array}$
C $\quad 10.25750 \quad 15.79586 \quad 8.01357$ 


$\begin{array}{lccc}\mathrm{C} & 11.29004 & 14.66025 & 7.92139 \\ \mathrm{C} & 6.85495 & 17.96934 & 10.14512 \\ \mathrm{C} & 7.87950 & 19.05649 & 10.51192 \\ \mathrm{C} & 9.44413 & 14.04466 & 12.05951 \\ \mathrm{C} & 10.64682 & 14.84819 & 12.58115 \\ \mathrm{O} & 8.47389 & 14.30795 & 8.68188 \\ \mathrm{O} & 5.31432 & 12.95277 & 7.91640 \\ \mathrm{C} & 4.21654 & 13.43549 & 7.36150 \\ \mathrm{C} & 4.36845 & 14.74046 & 6.55936 \\ \mathrm{C} & 2.99691 & 15.34722 & 6.24257 \\ \mathrm{O} & 6.38890 & 10.16282 & 8.99508 \\ \mathrm{C} & 5.38618 & 10.25747 & 10.04953 \\ \mathrm{C} & 5.80488 & 9.23269 & 11.09065 \\ \mathrm{C} & 6.46156 & 8.14859 & 10.23520 \\ \mathrm{C} & 7.20322 & 8.97775 & 9.19693 \\ \mathrm{~N} & 3.04802 & 12.90454 & 7.42233 \\ \mathrm{C} & 2.72076 & 11.70355 & 8.05295 \\ \mathrm{C} & 2.87806 & 10.46920 & 7.36998 \\ \mathrm{C} & 2.40744 & 9.30176 & 7.97533 \\ \mathrm{C} & 1.78846 & 9.32616 & 9.22347 \\ \mathrm{C} & 1.61606 & 10.54408 & 9.87392 \\ \mathrm{C} & 2.05899 & 11.74120 & 9.30555 \\ \mathrm{C} & 3.49034 & 10.44919 & 5.97845 \\ \mathrm{C} & 4.09819 & 9.10273 & 5.58065 \\ \mathrm{C} & 1.84667 & 13.07287 & 10.00549 \\ \mathrm{C} & 0.49320 & 13.17604 & 10.71706 \\ \mathrm{C} & 5.46101 & 18.58739 & 10.01628\end{array}$



$\begin{array}{llll}\text { C } & 9.28759 & 12.73604 & 12.83435\end{array}$
$\begin{array}{llll}\text { C } & 10.96200 & 17.08106 & 8.45683\end{array}$
$\begin{array}{llll}\text { C } & 9.61441 & 16.01674 & 6.63384\end{array}$
$\begin{array}{llll}\text { C } & 10.07137 & 12.13744 & 4.91429\end{array}$
$\begin{array}{llll}\text { C } & 8.33412 & 10.37393 & 4.53193\end{array}$
$\begin{array}{llll}\text { C } & 13.34777 & 10.43566 & 7.97042\end{array}$
$\begin{array}{llll}\text { C } & 10.59220 & 6.10732 & 6.29533\end{array}$
$\begin{array}{llll}\text { C } & 2.45440 & 10.90300 & 4.93729\end{array}$
$\begin{array}{llll}\text { C } & 2.99575 & 13.38882 & 10.97436\end{array}$
$\begin{array}{llll}\text { C } & 5.19330 & 15.75435 & 7.36415\end{array}$
$\begin{array}{llll}\text { C } & 5.09777 & 14.41932 & 5.24155\end{array}$
$\mathrm{H} \quad 4.41454 \quad 10.03560 \quad 9.60410$
$\begin{array}{llll}\mathrm{H} & 5.39984 & 11.28602 & 10.42401\end{array}$
$\begin{array}{llll}\mathrm{H} & 7.13567 & 17.57664 & 9.16047\end{array}$
$\begin{array}{llll}\text { H } & 9.64869 & 13.76483 & 11.01945\end{array}$
$\mathrm{H} \quad 1.11977 \quad 10.56665 \quad 10.84108$
$\begin{array}{llll}\mathrm{H} & 8.18568 & 9.29418 & 9.55948\end{array}$
$\begin{array}{llll}\mathrm{H} & 7.32062 & 8.48975 & 8.22789\end{array}$
$\mathrm{H} \quad 11.42181 \quad 11.30438 \quad 8.33701$
$\begin{array}{llll}\mathrm{H} & 1.43567 & 8.40409 & 9.67905\end{array}$
$\begin{array}{llll}\text { H } & 8.93726 & 7.40038 & 6.66493\end{array}$
$\mathrm{H} \quad 4.95050 \quad 8.87304 \quad 11.67132$
$\begin{array}{llll}\mathrm{H} & 6.53929 & 9.66940 & 11.77707\end{array}$
$\mathrm{H} \quad 9.32482 \quad 12.75285 \quad 5.43001$
$\begin{array}{llll}\mathrm{H} & 10.05769 & 12.41002 & 3.85214\end{array}$
$\begin{array}{llll}\mathrm{H} & 11.06380 & 12.37697 & 5.31238\end{array}$
$\begin{array}{llll}\mathrm{H} & 9.14658 & 12.90364 & 13.90929\end{array}$ 


$\begin{array}{cccc}\mathrm{H} & 10.19023 & 12.12580 & 12.72048 \\ \mathrm{H} & 8.44243 & 12.15546 & 12.44790 \\ \mathrm{H} & 2.53066 & 8.35111 & 7.46404 \\ \mathrm{H} & 4.30760 & 11.18091 & 5.97235 \\ \mathrm{H} & 4.74054 & 15.94510 & 8.34235 \\ \mathrm{H} & 5.24392 & 16.70507 & 6.82050 \\ \mathrm{H} & 6.21579 & 15.40735 & 7.53053 \\ \mathrm{H} & 1.86434 & 13.83332 & 9.21553 \\ \mathrm{H} & 8.07292 & 9.31296 & 4.62138 \\ \mathrm{H} & 8.28177 & 10.64823 & 3.47106 \\ \mathrm{H} & 7.58952 & 10.96653 & 5.07802 \\ \mathrm{H} & 6.07040 & 13.94808 & 5.43581 \\ \mathrm{H} & 5.26382 & 15.34285 & 4.67304 \\ \mathrm{H} & 4.50428 & 13.73866 & 4.62081 \\ \mathrm{H} & 7.14629 & 7.50367 & 10.79353 \\ \mathrm{H} & 5.69737 & 7.52158 & 9.76175 \\ \mathrm{H} & 9.96674 & 5.81115 & 9.81447 \\ \mathrm{H} & 10.78564 & 15.76303 & 11.99791 \\ \mathrm{H} & 11.56780 & 14.25569 & 12.51937 \\ \mathrm{H} & 10.49704 & 15.13179 & 13.63009 \\ \mathrm{H} & 14.10406 & 9.83356 & 8.48844 \\ \mathrm{H} & 13.81215 & 11.38570 & 7.68001 \\ \mathrm{H} & 13.05117 & 9.90526 & 7.06165 \\ \mathrm{H} & 1.62101 & 10.19156 & 4.88806 \\ \mathrm{H} & 2.90521 & 10.96690 & 3.93949 \\ \mathrm{H} & 2.05172 & 11.88535 & 5.19815 \\ \mathrm{H} & 2.37174 & 14.64600 & 5.68558\end{array}$




$\begin{array}{cccc}\mathrm{H} & 3.12848 & 16.25698 & 5.64408 \\ \mathrm{H} & 2.45818 & 15.61268 & 7.15767 \\ \mathrm{H} & 4.81877 & 8.75313 & 6.32669 \\ \mathrm{H} & 4.62395 & 9.19966 & 4.62483 \\ \mathrm{H} & 3.33395 & 8.32652 & 5.45147 \\ \mathrm{H} & 12.16240 & 9.20420 & 11.20405 \\ \mathrm{H} & 10.25915 & 17.91555 & 8.52458 \\ \mathrm{H} & 11.74242 & 17.34174 & 7.73105 \\ \mathrm{H} & 11.42539 & 16.96170 & 9.43972 \\ \mathrm{H} & 11.71647 & 11.64550 & 10.79740 \\ \mathrm{H} & 12.97097 & 12.43409 & 9.82988 \\ \mathrm{H} & 13.34460 & 10.94275 & 10.69052 \\ \mathrm{H} & 9.09786 & 15.11525 & 6.29064 \\ \mathrm{H} & 10.38360 & 16.27943 & 5.89777 \\ \mathrm{H} & 8.88537 & 16.83416 & 6.66764 \\ \mathrm{H} & 11.18611 & 6.97802 & 11.62146 \\ \mathrm{H} & 4.69653 & 17.83493 & 9.80081 \\ \mathrm{H} & 5.45119 & 19.32142 & 9.20271 \\ \mathrm{H} & 5.16548 & 19.11716 & 10.92990 \\ \mathrm{H} & 11.76558 & 14.48530 & 8.89218 \\ \mathrm{H} & 12.07393 & 14.92145 & 7.20057 \\ \mathrm{H} & 10.82630 & 13.72634 & 7.59489 \\ \mathrm{H} & 11.78168 & 9.97741 & 4.62994 \\ \mathrm{H} & 10.71950 & 10.12587 & 3.21270 \\ \mathrm{H} & 10.54841 & 8.75300 & 4.32894 \\ \mathrm{H} & 7.63921 & 19.49275 & 11.48900 \\ \mathrm{H} & 7.87582 & 19.86504 & 9.76998\end{array}$




$\begin{array}{llrl}\mathrm{H} & 8.88501 & 18.63221 & 10.56007 \\ \mathrm{H} & 11.24573 & 6.91179 & 5.94963 \\ \mathrm{H} & 10.13728 & 5.62629 & 5.42043 \\ \mathrm{H} & 11.20473 & 5.35983 & 6.81358 \\ \mathrm{H} & 9.08731 & 4.71574 & 8.13780 \\ \mathrm{H} & 8.03207 & 5.15095 & 6.79560 \\ \mathrm{H} & 7.80348 & 5.91033 & 8.37965 \\ \mathrm{H} & 3.03145 & 12.65414 & 11.78825 \\ \mathrm{H} & 2.87122 & 14.38048 & 11.42468 \\ \mathrm{H} & 3.96353 & 13.37261 & 10.46548 \\ \mathrm{H} & -0.33399 & 12.92540 & 10.04463 \\ \mathrm{H} & 0.33735 & 14.19709 & 11.08375 \\ \mathrm{H} & 0.43205 & 12.51194 & 11.58751 \\ \mathrm{H} & 5.42777 & 15.59048 & 13.93527 \\ \mathrm{H} & 7.36282 & 14.06468 & 13.84240 \\ \mathrm{H} & 5.17740 & 17.36420 & 12.23555\end{array}$

Complex 5- Triplet Th(III) with one arene bound

$\begin{array}{lrrr}\text { Th } & 7.63952 & 12.98497 & 8.09990 \\ \text { O } & 8.80650 & 11.08559 & 7.28412 \\ \text { O } & 8.25886 & 14.37747 & 6.26442 \\ \text { O } & 5.53786 & 12.67750 & 7.07356 \\ \text { O } & 6.63994 & 11.11223 & 9.70075 \\ \text { N } & 10.08775 & 9.15991 & 6.94854 \\ \text { N } & 3.27158 & 12.26653 & 6.71377 \\ \mathrm{~N} & 8.89970 & 16.23137 & 7.48178 \\ \text { C } & 8.62518 & 15.42743 & 8.61821\end{array}$



$\begin{array}{llll}\text { C } & 7.31316 & 15.46146 & 9.20279\end{array}$
$\begin{array}{llll}\text { C } & 9.64098 & 10.32600 & 6.61478\end{array}$
$\begin{array}{llll}\text { C } & 9.35263 & 13.64879 & 10.14661\end{array}$
$\begin{array}{llll}\text { C } & 7.04465 & 14.54154 & 10.26342\end{array}$
$\begin{array}{llll}\text { C } & 8.05822 & 13.66286 & 10.72633\end{array}$
$\begin{array}{llll}\text { C } & 8.71835 & 15.61320 & 6.36014\end{array}$
$\begin{array}{llll}\text { C } & 9.67128 & 14.56371 & 9.09881\end{array}$
$\begin{array}{llll}\text { C } & 4.41074 & 12.79790 & 6.41473\end{array}$
$\begin{array}{llll}\text { C } & 2.98465 & 11.40509 & 7.76510\end{array}$
$\begin{array}{llll}\text { C } & 9.83987 & 8.40862 & 8.09140\end{array}$
$\begin{array}{llll}\text { C } & 3.26832 & 10.01852 & 7.65805\end{array}$
$\begin{array}{llll}\text { C } & 9.08212 & 7.21067 & 7.96053\end{array}$
$\begin{array}{llll}\text { C } & 5.44453 & 11.29886 & 10.49910\end{array}$
$\mathrm{H} \quad 4.58584 \quad 11.18417 \quad 9.83697$
$\begin{array}{llll}\mathrm{H} & 5.45545 & 12.31578 & 10.90027\end{array}$
$\begin{array}{llll}\text { C } & 2.22739 & 11.88607 & 8.86575\end{array}$
$\begin{array}{llll}\text { C } & 6.36995 & 16.60397 & 8.86458\end{array}$
$\begin{array}{llll}\mathrm{H} & 6.40532 & 16.75536 & 7.77902\end{array}$
$\begin{array}{llll}\text { C } & 11.10156 & 14.82229 & 8.64711\end{array}$
$\mathrm{H} \quad 11.09948 \quad 14.93146 \quad 7.55531$
$\begin{array}{llll}\text { C } & 10.48591 & 8.69113 & 9.32563\end{array}$
$\begin{array}{llll}\text { C } & 1.80642 & 10.98567 & 9.84683\end{array}$
$\mathrm{H} \quad 1.23349 \quad 11.35125 \quad 10.69514$
$\begin{array}{llll}\text { C } & 7.37820 & 9.97259 & 10.18508\end{array}$
$\begin{array}{llll}\mathrm{H} & 8.17770 & 10.32248 & 10.85181\end{array}$

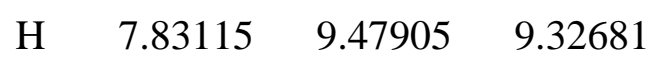
$\begin{array}{llll}\text { C } & 9.06747 & 16.32912 & 5.04734\end{array}$ 


$\begin{array}{cccc}\mathrm{C} & 10.16874 & 10.89677 & 5.28010 \\ \mathrm{C} & 11.43122 & 9.87563 & 9.42885 \\ \mathrm{H} & 10.94782 & 10.71826 & 8.91980 \\ \mathrm{C} & 2.10649 & 9.62835 & 9.76121 \\ \mathrm{H} & 1.77141 & 8.94091 & 10.53414 \\ \mathrm{C} & 8.55825 & 6.79965 & 6.59279 \\ \mathrm{H} & 8.17369 & 7.70321 & 6.10385 \\ \mathrm{C} & 5.48799 & 10.22242 & 11.58184 \\ \mathrm{H} & 4.48314 & 9.87955 & 11.84073 \\ \mathrm{H} & 5.96923 & 10.60087 & 12.49177 \\ \mathrm{C} & 11.13431 & 12.05039 & 5.60249 \\ \mathrm{H} & 10.64076 & 12.83562 & 6.18128 \\ \mathrm{H} & 11.50639 & 12.50113 & 4.67504 \\ \mathrm{H} & 11.99718 & 11.68664 & 6.17082 \\ \mathrm{C} & 12.08560 & 13.70792 & 8.99658 \\ \mathrm{H} & 12.22352 & 13.62132 & 10.08074 \\ \mathrm{H} & 13.06819 & 13.92068 & 8.56007 \\ \mathrm{H} & 11.74859 & 12.73982 & 8.61674 \\ \mathrm{C} & 2.82768 & 9.15801 & 8.66617 \\ \mathrm{H} & 3.04641 & 8.09613 & 8.59213 \\ \mathrm{C} & 3.95853 & 9.49706 & 6.40937 \\ \mathrm{H} & 4.70581 & 10.24305 & 6.11849 \\ \mathrm{C} & 4.69732 & 15.13559 & 5.60036 \\ \mathrm{H} & 3.89200 & 15.49632 & 6.24943 \\ \mathrm{H} & 4.74911 & 15.79574 & 4.72710 \\ \mathrm{H} & 5.64332 & 15.21249 & 6.14146 \\ \mathrm{C} & 1.83818 & 13.35387 & 8.91573\end{array}$




$\begin{array}{cccc}\mathrm{H} & 2.65901 & 13.91645 & 8.45709 \\ \mathrm{C} & 8.99668 & 11.42373 & 4.43985 \\ \mathrm{H} & 8.24766 & 10.64273 & 4.26723 \\ \mathrm{H} & 9.36154 & 11.75856 & 3.46137 \\ \mathrm{H} & 8.51083 & 12.27540 & 4.91846 \\ \mathrm{C} & 5.56253 & 13.21884 & 4.22516 \\ \mathrm{H} & 6.53856 & 13.33497 & 4.69934 \\ \mathrm{H} & 5.55833 & 13.81501 & 3.30470 \\ \mathrm{H} & 5.43060 & 12.16828 & 3.94226 \\ \mathrm{C} & 6.35401 & 9.13952 & 10.93602 \\ \mathrm{H} & 6.82249 & 8.45929 & 11.65188 \\ \mathrm{H} & 5.76031 & 8.54704 & 10.23226 \\ \mathrm{C} & 8.90195 & 6.39239 & 9.07715 \\ \mathrm{H} & 8.30347 & 5.49067 & 8.98540 \\ \mathrm{C} & 11.59728 & 16.16067 & 9.22375 \\ \mathrm{H} & 10.94282 & 16.97561 & 8.90501 \\ \mathrm{H} & 12.61847 & 16.38062 & 8.88512 \\ \mathrm{H} & 11.60261 & 16.12618 & 10.31997 \\ \mathrm{C} & 12.74764 & 9.57145 & 8.69422 \\ \mathrm{H} & 13.28354 & 8.75508 & 9.19353 \\ \mathrm{H} & 13.40211 & 10.45123 & 8.68510 \\ \mathrm{H} & 12.55359 & 9.27288 & 7.66102 \\ \mathrm{C} & 2.94269 & 9.38150 & 5.26059 \\ \mathrm{H} & 2.18332 & 8.62556 & 5.49483 \\ \mathrm{H} & 3.43805 & 9.08649 & 4.32753 \\ \mathrm{H} & 2.43711 & 10.33697 & 5.09788 \\ \mathrm{C} & 3.10420 & 13.63108 & 4.39990\end{array}$




$\begin{array}{cccc}\mathrm{H} & 2.88080 & 12.61544 & 4.06082 \\ \mathrm{H} & 3.15558 & 14.28518 & 3.52010 \\ \mathrm{H} & 2.27315 & 13.95754 & 5.02946 \\ \mathrm{C} & 4.43503 & 13.68774 & 5.15663 \\ \mathrm{C} & 4.69812 & 8.17508 & 6.60586 \\ \mathrm{H} & 5.41711 & 8.23620 & 7.42844 \\ \mathrm{H} & 5.25191 & 7.91745 & 5.69713 \\ \mathrm{H} & 4.01269 & 7.34336 & 6.80972 \\ \mathrm{C} & 10.28615 & 7.83082 & 10.40808 \\ \mathrm{H} & 10.76731 & 8.05142 & 11.35652 \\ \mathrm{C} & 9.66781 & 17.71143 & 5.32146 \\ \mathrm{H} & 8.97043 & 18.33937 & 5.88165 \\ \mathrm{H} & 9.90646 & 18.20838 & 4.37199 \\ \mathrm{H} & 10.58217 & 17.63372 & 5.91557 \\ \mathrm{C} & 11.72507 & 10.32135 & 10.86278 \\ \mathrm{H} & 10.80732 & 10.52178 & 11.42587 \\ \mathrm{H} & 12.31997 & 11.23994 & 10.85303 \\ \mathrm{H} & 12.30259 & 9.56912 & 11.41398 \\ \mathrm{C} & 7.79922 & 16.48710 & 4.19494 \\ \mathrm{H} & 7.33979 & 15.51738 & 3.99321 \\ \mathrm{H} & 8.04507 & 16.96084 & 3.23634 \\ \mathrm{H} & 7.06060 & 17.11623 & 4.70280 \\ \mathrm{C} & 9.48436 & 6.69870 & 10.30342 \\ \mathrm{H} & 9.33339 & 6.04955 & 11.16249 \\ \mathrm{C} & 4.91452 & 16.34067 & 9.25235 \\ \mathrm{H} & 4.56403 & 15.38154 & 8.85902 \\ \mathrm{H} & 4.26547 & 17.13104 & 8.85843\end{array}$




$\begin{array}{cccc}\mathrm{H} & 4.78298 & 16.32782 & 10.34100 \\ \mathrm{C} & 10.08328 & 15.47322 & 4.27370 \\ \mathrm{H} & 11.01340 & 15.35693 & 4.84063 \\ \mathrm{H} & 10.32891 & 15.95004 & 3.31669 \\ \mathrm{H} & 9.68119 & 14.47742 & 4.07434 \\ \mathrm{C} & 10.91960 & 9.83492 & 4.47035 \\ \mathrm{H} & 11.76636 & 9.43043 & 5.02962 \\ \mathrm{H} & 11.29441 & 10.28039 & 3.54010 \\ \mathrm{H} & 10.26498 & 8.99805 & 4.21039 \\ \mathrm{C} & 6.86845 & 17.91106 & 9.50597 \\ \mathrm{H} & 6.88839 & 17.82086 & 10.59883 \\ \mathrm{H} & 6.21466 & 18.75406 & 9.24568 \\ \mathrm{H} & 7.88007 & 18.13911 & 9.15998 \\ \mathrm{C} & 9.71611 & 6.26871 & 5.72976 \\ \mathrm{H} & 10.51545 & 7.00960 & 5.66467 \\ \mathrm{H} & 9.37139 & 6.03630 & 4.71439 \\ \mathrm{H} & 10.12553 & 5.34955 & 6.16619 \\ \mathrm{C} & 7.43008 & 5.76668 & 6.63287 \\ \mathrm{H} & 7.78796 & 4.79187 & 6.98600 \\ \mathrm{H} & 7.02674 & 5.61353 & 5.62588 \\ \mathrm{H} & 6.60596 & 6.07926 & 7.28068 \\ \mathrm{C} & 1.63430 & 13.90339 & 10.32947 \\ \mathrm{H} & 0.75072 & 13.47174 & 10.81504 \\ \mathrm{H} & 1.48245 & 14.98762 & 10.29225 \\ \mathrm{H} & 2.50069 & 13.70647 & 10.96914 \\ \mathrm{H} & 0.58835 & 13.59573 & 8.05416 \\ & 0.75788 & 13.24508 & 7.03290\end{array}$




$\begin{array}{llll}\mathrm{H} & 0.33590 & 14.66271 & 8.01812 \\ \mathrm{H} & -0.27340 & 13.05658 & 8.46609 \\ \mathrm{H} & 7.81941 & 12.93899 & 11.50134 \\ \mathrm{H} & 10.11718 & 12.99881 & 10.55718 \\ \mathrm{H} & 6.08675 & 14.57157 & 10.77196\end{array}$

\section{Complex 5- Triplet Th(III) with arenes unbound}
$\begin{array}{llll}\text { C } & 10.56191 & 7.32054 & 10.49845\end{array}$
C $\quad 9.64745 \quad 6.73883 \quad 9.62513$
C $\quad 9.44060 \quad 7.25582 \quad 8.34375$
C $\quad 10.17239 \quad 8.40085 \quad 7.93747$
C $\quad 11.12349 \quad 8.98469 \quad 8.81264$
C $\quad 11.29492 \quad 8.42871 \quad 10.08295$
$\begin{array}{llll}\mathrm{N} & 10.04780 & 8.83507 & 6.61524\end{array}$
C $\quad 9.43490 \quad 9.91071 \quad 6.25696$
C $\quad 9.45401 \quad 10.28160 \quad 4.76274$
C $\quad 9.90659 \quad 9.09426 \quad 3.90627$
$\begin{array}{llll}\text { C } & 8.49247 & 6.58864 & 7.35968\end{array}$
$\begin{array}{llll}\text { C } & 7.36328 & 5.79169 & 8.01663\end{array}$
C $\quad 11.98494 \quad 10.14094 \quad 8.32943$
C $\quad 12.57009 \quad 11.00030 \quad 9.45124$
$\begin{array}{llll}\text { O } & 8.81224 & 10.74465 & 7.06276\end{array}$
Th $\quad 8.12312 \quad 12.66181 \quad 8.08454$
$\begin{array}{llll}\text { C } & 8.61697 & 14.73458 & 12.23005\end{array}$
C $\quad 8.03157 \quad 15.67963 \quad 11.35145$
C $\quad \begin{array}{lll}6.68126 & 16.07192 & 11.52313\end{array}$
$\begin{array}{llll}\text { C } & 5.93091 & 15.47892 & 12.54125\end{array}$ 

$\begin{array}{llll}\text { C } & 6.48948 & 14.52903 & 13.39210\end{array}$
$\begin{array}{llll}\text { C } & 7.82616 & 14.17319 & 13.23607\end{array}$
$\begin{array}{llll}\mathrm{N} & 8.82699 & 16.34428 & 10.40857\end{array}$
$\begin{array}{llll}\text { C } & 9.02724 & 15.88622 & 9.22201\end{array}$
$\begin{array}{llll}\text { C } & 9.95825 & 16.66273 & 8.27732\end{array}$
$\begin{array}{llll}\text { C } & 11.25777 & 15.85163 & 8.11422\end{array}$
$\begin{array}{llll}\text { C } & 6.10758 & 17.17530 & 10.64789\end{array}$
$\begin{array}{llll}\text { C } & 6.61100 & 18.54632 & 11.12970\end{array}$
$\begin{array}{llll}\text { C } & 10.10164 & 14.42317 & 12.11914\end{array}$
$\begin{array}{llll}\text { C } & 10.92515 & 15.55597 & 12.75389\end{array}$
$\begin{array}{llll}\text { O } & 8.50956 & 14.77396 & 8.74154\end{array}$
$\begin{array}{llll}\text { O } & 5.90929 & 12.93388 & 7.52504\end{array}$
$\begin{array}{llll}\text { C } & 4.80149 & 13.30567 & 6.92341\end{array}$
$\begin{array}{llll}\text { C } & 4.91821 & 14.50362 & 5.96330\end{array}$
$\begin{array}{llll}\text { C } & 3.56889 & 14.83513 & 5.31901\end{array}$
$\begin{array}{llll}\text { O } & 7.08399 & 10.97396 & 9.79871\end{array}$
$\begin{array}{llll}\text { C } & 6.04473 & 11.47885 & 10.68012\end{array}$
$\begin{array}{llll}\text { C } & 5.93381 & 10.46511 & 11.82721\end{array}$
$\begin{array}{llll}\text { C } & 6.69052 & 9.24146 & 11.29822\end{array}$
$\begin{array}{llll}\text { C } & 7.77275 & 9.89195 & 10.45460\end{array}$
$\begin{array}{llll}\mathrm{N} & 3.63740 & 12.76938 & 7.07623\end{array}$
$\begin{array}{llll}\text { C } & 3.35702 & 11.69830 & 7.92806\end{array}$
$\begin{array}{llll}\text { C } & 3.58322 & 10.35982 & 7.51894\end{array}$
$\begin{array}{llll}\text { C } & 3.17805 & 9.32064 & 8.36037\end{array}$
$\begin{array}{llll}\text { C } & 2.54530 & 9.57140 & 9.57461\end{array}$
$\begin{array}{llll}\text { C } & 2.29225 & 10.88666 & 9.95293\end{array}$
$\begin{array}{llll}\text { C } & 2.68156 & 11.96040 & 9.14838\end{array}$ 


$\begin{array}{lccc}\mathrm{C} & 4.17956 & 10.08468 & 6.14775 \\ \mathrm{C} & 4.80021 & 8.69466 & 6.00203 \\ \mathrm{C} & 2.34024 & 13.39446 & 9.52057 \\ \mathrm{C} & 1.08343 & 13.84937 & 8.76070 \\ \mathrm{C} & 4.58103 & 17.17258 & 10.55212 \\ \mathrm{C} & 10.50473 & 13.06887 & 12.70316 \\ \mathrm{C} & 10.28735 & 18.04541 & 8.84834 \\ \mathrm{C} & 9.29227 & 16.81932 & 6.90158 \\ \mathrm{C} & 10.44374 & 11.44738 & 4.58011 \\ \mathrm{C} & 8.05565 & 10.72508 & 4.31181 \\ \mathrm{C} & 13.10155 & 9.61960 & 7.40966 \\ \mathrm{C} & 9.28131 & 5.70188 & 6.38267 \\ \mathrm{C} & 3.11868 & 10.31291 & 5.05751 \\ \mathrm{C} & 2.17696 & 13.63368 & 11.02324 \\ \mathrm{C} & 5.41140 & 15.72500 & 6.75718 \\ \mathrm{C} & 5.93509 & 14.16953 & 4.85980 \\ \mathrm{H} & 5.13351 & 11.54964 & 10.08484 \\ \mathrm{H} & 6.33214 & 12.47509 & 11.03600 \\ \mathrm{H} & 6.49985 & 17.02096 & 9.63590 \\ \mathrm{H} & 10.34690 & 14.39310 & 11.05098 \\ \mathrm{H} & 1.78243 & 11.08076 & 10.89277 \\ \mathrm{H} & 8.58184 & 10.30013 & 11.07614 \\ \mathrm{H} & 8.20756 & 9.26005 & 9.68064 \\ \mathrm{H} & 11.34301 & 10.79859 & 7.72997 \\ \mathrm{H} & 2.23996 & 8.74706 & 10.21448 \\ \mathrm{H} & 8.03196 & 7.38817 & 6.76763 \\ & 4.88986 & 10.24998 & 12.06938\end{array}$




\begin{tabular}{cccc}
$\mathrm{H}$ & 6.42040 & 10.85462 & 12.72772 \\
$\mathrm{H}$ & 10.17821 & 12.29668 & 5.22405 \\
$\mathrm{H}$ & 10.43841 & 11.78588 & 3.53648 \\
$\mathrm{H}$ & 11.46291 & 11.13425 & 4.83246 \\
$\mathrm{H}$ & 10.36596 & 13.02722 & 13.79047 \\
$\mathrm{H}$ & 11.56575 & 12.87964 & 12.50705 \\
$\mathrm{H}$ & 9.92941 & 12.25702 & 12.24510 \\
$\mathrm{H}$ & 3.35911 & 8.29220 & 8.06134 \\
$\mathrm{H}$ & 4.97978 & 10.81644 & 5.98890 \\
$\mathrm{H}$ & 4.69307 & 16.00068 & 7.53689 \\
$\mathrm{H}$ & 5.52820 & 16.58496 & 6.08701 \\
$\mathrm{H}$ & 6.37581 & 15.53208 & 7.23403 \\
$\mathrm{H}$ & 3.17035 & 14.02140 & 9.17459 \\
$\mathrm{H}$ & 7.32152 & 9.92373 & 4.44804 \\
$\mathrm{H}$ & 8.07357 & 10.99170 & 3.24852 \\
$\mathrm{H}$ & 7.71551 & 11.59963 & 4.87340 \\
$\mathrm{H}$ & 6.92210 & 13.93734 & 5.27994 \\
$\mathrm{H}$ & 6.05080 & 15.02409 & 4.18282 \\
$\mathrm{H}$ & 5.60683 & 13.30896 & 4.26634 \\
$\mathrm{H}$ & 7.10165 & 8.60933 & 12.09073 \\
$\mathrm{H}$ & 6.03851 & 8.62937 & 10.66611 \\
$\mathrm{H}$ & 9.08384 & 5.86771 & 9.94853 \\
$\mathrm{H}$ & 10.66955 & 16.51745 & 12.30059 \\
$\mathrm{H}$ & 11.99949 & 15.38235 & 12.61635 \\
\hline & 10.72773 & 15.61910 & 13.83097 \\
$\mathrm{H}$ & 13.680099 & 8.97322 & 7.96748 \\
\hline
\end{tabular}




$\begin{array}{cccc}\mathrm{H} & 12.68248 & 9.04041 & 6.58230 \\ \mathrm{H} & 2.30366 & 9.58612 & 5.15862 \\ \mathrm{H} & 3.55474 & 10.19640 & 4.05793 \\ \mathrm{H} & 2.69529 & 11.31763 & 5.13612 \\ \mathrm{H} & 3.18490 & 13.99047 & 4.74069 \\ \mathrm{H} & 3.68366 & 15.69417 & 4.64606 \\ \mathrm{H} & 2.81915 & 15.08316 & 6.07468 \\ \mathrm{H} & 5.54626 & 8.50065 & 6.77858 \\ \mathrm{H} & 5.29517 & 8.60612 & 5.02907 \\ \mathrm{H} & 4.04371 & 7.90188 & 6.04812 \\ \mathrm{H} & 12.01276 & 8.87522 & 10.76502 \\ \mathrm{H} & 9.38251 & 18.64796 & 8.97418 \\ \mathrm{H} & 10.96308 & 18.57508 & 8.16546 \\ \mathrm{H} & 10.76795 & 17.96676 & 9.82633 \\ \mathrm{H} & 11.78726 & 11.36288 & 10.12586 \\ \mathrm{H} & 13.07412 & 11.87355 & 9.02331 \\ \mathrm{H} & 13.31455 & 10.45464 & 10.04454 \\ \mathrm{H} & 9.07123 & 15.84199 & 6.46153 \\ \mathrm{H} & 9.96484 & 17.35716 & 6.22275 \\ \mathrm{H} & 8.35856 & 17.38852 & 6.97214 \\ \mathrm{H} & 10.70839 & 6.90858 & 11.49403 \\ \mathrm{H} & 4.19577 & 16.19391 & 10.24968 \\ \mathrm{H} & 4.25019 & 17.91060 & 9.81298 \\ \mathrm{H} & 4.11103 & 17.44147 & 11.50592 \\ \mathrm{H} & 11.76367 & 15.72242 & 9.07759 \\ \mathrm{H} & 11.94336 & 16.37756 & 7.43831 \\ \mathrm{H} & 11.05061 & 14.86150 & 7.69005\end{array}$




$$
\begin{array}{cccc}
\mathrm{H} & 10.90149 & 8.75156 & 4.19906 \\
\mathrm{H} & 9.93227 & 9.39084 & 2.85029 \\
\mathrm{H} & 9.22264 & 8.24577 & 4.00873 \\
\mathrm{H} & 6.24145 & 18.75531 & 12.14084 \\
\mathrm{H} & 6.25899 & 19.34740 & 10.46785 \\
\mathrm{H} & 7.70352 & 18.56727 & 11.14907 \\
\mathrm{H} & 10.04473 & 6.29105 & 5.86887 \\
\mathrm{H} & 8.61683 & 5.26111 & 5.62908 \\
\mathrm{H} & 9.77559 & 4.88326 & 6.91959 \\
\mathrm{H} & 7.73699 & 4.89713 & 8.52925 \\
\mathrm{H} & 6.65243 & 5.45110 & 7.25570 \\
\mathrm{H} & 6.81297 & 6.39336 & 8.74735 \\
\mathrm{H} & 1.29828 & 13.11723 & 11.42787 \\
\mathrm{H} & 2.03732 & 14.70242 & 11.21882 \\
\mathrm{H} & 3.05571 & 13.30152 & 11.58506 \\
\mathrm{H} & 1.22350 & 13.72124 & 7.68437 \\
\mathrm{H} & 0.86506 & 14.90576 & 8.96024 \\
\mathrm{H} & 0.21230 & 13.25893 & 9.06950 \\
\mathrm{H} & 5.88942 & 14.07723 & 14.17828 \\
\mathrm{H} & 8.26392 & 13.44249 & 13.91017 \\
\mathrm{H} & 4.89134 & 15.76442 & 12.67435
\end{array}
$$

\section{Complex 7}
U $\quad 6.817590000 \quad 12.848740000$
5.181639000
$\begin{array}{llll}\text { O } & 6.802664000 & 15.110803000 & 4.805988000\end{array}$
$\begin{array}{llll}\text { O } & 5.939369000 & 13.136208000 & 7.303210000\end{array}$
$\begin{array}{llll}\text { O } & 4.280912000 & 13.153499000 & 4.437001000\end{array}$
$\begin{array}{llll}\mathrm{N} & 7.627578000 & 17.045510000 & 3.827277000\end{array}$ 


\begin{tabular}{|c|c|c|c|}
\hline 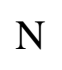 & 00 & 0 & 00 \\
\hline $\mathrm{C}$ & .790527000 & 16.395017000 & 4.565350000 \\
\hline C & 5.939065000 & 13.145041000 & 8.605885000 \\
\hline $\mathrm{C}$ & 8.823734000 & 11.397138000 & 5.775458000 \\
\hline $\mathrm{H}$ & 9.413168000 & 11.464329000 & 6.687786000 \\
\hline $\mathrm{C}$ & 5000 & 00 & 00 \\
\hline $\mathrm{H}$ & 8000 & 00 & 8000 \\
\hline $\mathrm{C}$ & 8.636330000 & 12.424838000 & 3.431451000 \\
\hline $\mathrm{H}$ & 9.072263000 & 13.208607000 & 2.817744000 \\
\hline $\mathrm{C}$ & 7.466169000 & 11.811599000 & 2.909365000 \\
\hline $\mathrm{H}$ & 7.148417000 & 12.164 & 24000 \\
\hline $\mathrm{C}$ & 36000 & $10.8^{\prime}$ & 3.54 \\
\hline $\mathrm{H}$ & 5.70 & 10.60 & 00 \\
\hline $\mathrm{C}$ & 6.7 & 10 & 00 \\
\hline $\mathrm{H}$ & 5000 & 9.658356000 & 5.138164000 \\
\hline $\mathrm{C}$ & 7.694942000 & 10.529238000 & 5.830625000 \\
\hline $\mathrm{H}$ & 7.521596000 & 10.041525000 & 6.788064000 \\
\hline $\mathrm{C}$ & 5.649632000 & 17.193001000 & 5.225525000 \\
\hline 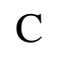 & 5.688066000 & 16.951027000 & 6.742570000 \\
\hline $\mathrm{H}$ & 5 & 1 & 00 \\
\hline $\mathrm{H}$ & 00 & 0 & 00 \\
\hline $\mathrm{H}$ & 6.623185000 & 17.326194000 & 7.174187000 \\
\hline $\mathrm{C}$ & 5.772805000 & 18.692944000 & 4.945748000 \\
\hline $\mathrm{H}$ & 6.713916000 & 19.092405000 & 5.333447000 \\
\hline $\mathrm{H}$ & 3000 & 19.228837000 & 5.425431000 \\
\hline $\mathrm{H}$ & 5.748297000 & 18.89 & 00 \\
\hline & 000 & 000 & 4.665486000 \\
\hline
\end{tabular}




\begin{tabular}{llll}
$\mathrm{H}$ & 4.243987000 & 16.869553000 & 3.587794000 \\
$\mathrm{H}$ & 3.474652000 & 17.194891000 & 5.150587000 \\
$\mathrm{H}$ & 4.206618000 & 15.604499000 & 4.835420000 \\
$\mathrm{C}$ & 8.699054000 & 16.438779000 & 3.161155000 \\
$\mathrm{C}$ & 9.959521000 & 16.324973000 & 3.797045000 \\
$\mathrm{C}$ & 11.044929000 & 15.843294000 & 3.062171000 \\
$\mathrm{H}$ & 12.013083000 & 15.740582000 & 3.544512000 \\
$\mathrm{C}$ & 10.912104000 & 15.481737000 & 1.724938000 \\
$\mathrm{H}$ & 11.766714000 & 15.098790000 & 1.172892000 \\
$\mathrm{C}$ & 9.673628000 & 15.608231000 & 1.103155000 \\
$\mathrm{H}$ & 9.572644000 & 15.322127000 & 0.059667000 \\
$\mathrm{C}$ & 8.558815000 & 16.082683000 & 1.797446000 \\
$\mathrm{C}$ & 7.216716000 & 16.277913000 & 1.110136000 \\
$\mathrm{H}$ & 6.443310000 & 16.044633000 & 1.851230000 \\
$\mathrm{C}$ & 7.033584000 & 17.751005000 & 0.711098000 \\
$\mathrm{H}$ & 7.148393000 & 18.396909000 & 1.585532000 \\
$\mathrm{H}$ & 6.039709000 & 17.923261000 & 0.278531000 \\
$\mathrm{H}$ & 7.782663000 & 18.042862000 & -0.034972000 \\
$\mathrm{C}$ & 6.988239000 & 15.359045000 & -0.092090000 \\
$\mathrm{H}$ & 7.652432000 & 15.605312000 & -0.929233000 \\
$\mathrm{H}$ & 5.960412000 & 15.466066000 & -0.458133000 \\
$\mathrm{H}$ & 7.150491000 & 14.308439000 & 0.168782000 \\
$\mathrm{H}$ & 10.114287000 & 16.786532000 & 5.237543000 \\
$\mathrm{H}$ & 9.198225000 & 16.497979000 & 5.765749000 \\
\hline & 10.214204000 & 18.319691000 & 5.295219000 \\
$\mathrm{H}$ & 11.125003000 & 18.664076000 & 4.790308000 \\
$\mathrm{H}$ & &
\end{tabular}




\begin{tabular}{|c|c|c|c|}
\hline $\mathrm{H}$ & 9.352863000 & 18.776614000 & 4.800820000 \\
\hline $\mathrm{C}$ & 11.285931000 & 16.142927000 & 5.981734000 \\
\hline $\mathrm{H}$ & 11.244511000 & 15.050622000 & 5.928850000 \\
\hline $\mathrm{H}$ & 11.262743000 & 16.432158000 & 7.038415000 \\
\hline $\mathrm{H}$ & 12.254369000 & 16.466677000 & 5.581378000 \\
\hline $\mathrm{C}$ & 7.267554000 & 13.486259000 & 9.320492000 \\
\hline $\mathrm{C}$ & 8.218565000 & 14.255281000 & 8.398034000 \\
\hline $\mathrm{H}$ & 8.530727000 & 13.645998000 & 7.541775000 \\
\hline $\mathrm{H}$ & 9.127640000 & 14.527251000 & 8.947438000 \\
\hline $\mathrm{H}$ & 7.763633000 & 15.175387000 & 8.021323000 \\
\hline $\mathrm{C}$ & 6.993568000 & 14.318280000 & 10.580416000 \\
\hline $\mathrm{H}$ & 6.549267000 & 15.286658000 & 10.325250000 \\
\hline $\mathrm{H}$ & 7.930201000 & 14.507511000 & 11.119490000 \\
\hline $\mathrm{H}$ & 6.300804000 & 13.794937000 & 11.242608000 \\
\hline $\mathrm{C}$ & 7.927292000 & 12.154604000 & 9.724656000 \\
\hline $\mathrm{H}$ & 7.289265000 & 11.602972000 & 10.421289000 \\
\hline $\mathrm{H}$ & 8.893107000 & 12.340465000 & 10.210869000 \\
\hline $\mathrm{H}$ & 8.106448000 & 11.527690000 & 8.845344000 \\
\hline $\mathrm{C}$ & 3.687566000 & 12.455332000 & 8.878371000 \\
\hline $\mathrm{C}$ & 2.635869000 & 13.403634000 & 8.785572000 \\
\hline $\mathrm{C}$ & 1.363038000 & 12.972409000 & 8.405316000 \\
\hline $\mathrm{H}$ & 0.556195000 & 13.696219000 & 8.325124000 \\
\hline $\mathrm{C}$ & 1.105053000 & 11.633374000 & 8.124669000 \\
\hline $\mathrm{H}$ & 0.108116000 & 11.316120000 & 7.827929000 \\
\hline $\mathrm{C}$ & 2.133664000 & 10.702485000 & 8.241350000 \\
\hline $\mathrm{H}$ & 1.927944000 & 9.656091000 & 8.032948000 \\
\hline $\mathrm{C}$ & 3.424107000 & 11.084793000 & 8.617393000 \\
\hline
\end{tabular}




\begin{tabular}{llll}
$\mathrm{C}$ & 4.527926000 & 10.058904000 & 8.818325000 \\
$\mathrm{H}$ & 5.457849000 & 10.510666000 & 8.454918000 \\
$\mathrm{C}$ & 4.707167000 & 9.767321000 & 10.317248000 \\
$\mathrm{H}$ & 4.888406000 & 10.694232000 & 10.867774000 \\
$\mathrm{H}$ & 5.553543000 & 9.090551000 & 10.486402000 \\
$\mathrm{H}$ & 3.806649000 & 9.293071000 & 10.726398000 \\
$\mathrm{C}$ & 4.326491000 & 8.756777000 & 8.040718000 \\
$\mathrm{H}$ & 3.477026000 & 8.176634000 & 8.421946000 \\
$\mathrm{H}$ & 5.215977000 & 8.124575000 & 8.133525000 \\
$\mathrm{H}$ & 4.160144000 & 8.944489000 & 6.975339000 \\
$\mathrm{C}$ & 2.902293000 & 14.851359000 & 9.164506000 \\
$\mathrm{H}$ & 3.919665000 & 15.086934000 & 8.833091000 \\
$\mathrm{C}$ & 1.958836000 & 15.858598000 & 8.503677000 \\
$\mathrm{H}$ & 1.940315000 & 15.741882000 & 7.415311000 \\
$\mathrm{H}$ & 2.284842000 & 16.880401000 & 8.727452000 \\
$\mathrm{H}$ & 0.930436000 & 15.762756000 & 8.872820000 \\
$\mathrm{C}$ & 2.876019000 & 15.008140000 & 10.693515000 \\
$\mathrm{H}$ & 1.876710000 & 14.784284000 & 11.086339000 \\
$\mathrm{H}$ & 3.135407000 & 16.032531000 & 10.988136000 \\
$\mathrm{H}$ & 3.591352000 & 14.324022000 & 11.156669000 \\
$\mathrm{C}$ & 3.145954000 & 12.634162000 & 5.146975000 \\
$\mathrm{H}$ & 2.402415000 & 13.433576000 & 5.275456000 \\
$\mathrm{H}$ & 3.484732000 & 12.308347000 & 6.130232000 \\
$\mathrm{C}$ & 2.630762000 & 11.530298000 & 4.237510000 \\
$\mathrm{H}$ & 1.591141000 & 11.265071000 & 4.447434000 \\
\hline & 2.2434267000 & 12.131014000 & 2.835145000
\end{tabular}




$\begin{array}{llll}\mathrm{H} & 3.124645000 & 11.373854000 & 2.101874000 \\ \mathrm{H} & 1.915912000 & 12.606342000 & 2.474796000 \\ \mathrm{C} & 3.942352000 & 13.185486000 & 3.040077000 \\ \mathrm{H} & 4.859612000 & 12.970079000 & 2.487888000 \\ \mathrm{H} & 3.596479000 & 14.194743000 & 2.783629000\end{array}$

\section{Complex 8}

$\begin{array}{llll}\mathrm{U} & 4.145153000 & 8.565432000 & 30.790395000 \\ \mathrm{U} & 9.030449000 & 7.244046000 & 31.434472000 \\ \mathrm{O} & 11.214403000 & 7.007739000 & 30.949567000 \\ \mathrm{O} & 9.760715000 & 8.973883000 & 32.702501000 \\ \mathrm{O} & 2.357060000 & 7.434109000 & 30.629680000 \\ \mathrm{O} & 3.968936000 & 9.659196000 & 28.893412000 \\ \mathrm{O} & 3.219187000 & 10.125355000 & 31.948512000 \\ \mathrm{O} & 8.779029000 & 5.169925000 & 31.105593000 \\ \mathrm{~N} & 9.128772000 & 3.819962000 & 29.353687000 \\ \mathrm{~N} & 1.231163000 & 6.074991000 & 32.010185000 \\ \mathrm{~N} & 2.695053000 & 11.371887000 & 33.838213000 \\ \mathrm{~N} & 3.195734000 & 10.639966000 & 26.918198000 \\ \mathrm{~N} & 10.273530000 & 8.432981000 & 29.565161000 \\ \mathrm{~N} & 9.837756000 & 7.070253000 & 33.813545000 \\ \mathrm{C} & -2.792269000 & 7.082464000 & 32.006339000 \\ \mathrm{C} & -1.541072000 & 7.653170000 & 34.123212000 \\ \mathrm{C} & 10.787535000 & 6.916183000 & 26.014247000 \\ \mathrm{C} & -0.940013000 & 11.526052000 & 27.585214000 \\ \mathrm{C} & 2.203446000 & 2.025535000 & 31.627357000 \\ \mathrm{C} & 12.489310000 & 1.753405000 & 29.889108000\end{array}$




\begin{tabular}{lrrr}
$\mathrm{C}$ & 6.347793000 & 3.477599000 & 26.715238000 \\
$\mathrm{C}$ & 2.978306000 & 3.223012000 & 33.710525000 \\
$\mathrm{C}$ & -1.431924000 & 3.281760000 & 33.710550000 \\
$\mathrm{C}$ & 4.172890000 & 14.217197000 & 34.216949000 \\
$\mathrm{C}$ & 11.826605000 & 12.170879000 & 30.297001000 \\
$\mathrm{C}$ & 0.674101000 & 12.549082000 & 25.939233000 \\
$\mathrm{C}$ & 13.880685000 & 6.408997000 & 34.591197000 \\
$\mathrm{C}$ & 0.306395000 & 8.082722000 & 25.262827000 \\
$\mathrm{C}$ & 7.427861000 & 6.995156000 & 36.989769000 \\
$\mathrm{C}$ & 12.759611000 & 3.160927000 & 27.817497000 \\
$\mathrm{C}$ & 1.315451000 & 10.099383000 & 36.473855000 \\
$\mathrm{C}$ & 6.421435000 & 13.524283000 & 33.323199000 \\
$\mathrm{C}$ & 5.639920000 & 1.743611000 & 28.397339000 \\
$\mathrm{C}$ & -1.454873000 & 6.969309000 & 32.750699000 \\
$\mathrm{C}$ & 4.709651000 & 9.820616000 & 36.509208000 \\
$\mathrm{C}$ & 9.963968000 & 11.270563000 & 26.445179000 \\
$\mathrm{C}$ & -0.979825000 & 5.532679000 & 32.900349000 \\
$\mathrm{C}$ & 6.727905000 & 2.757507000 & 28.016873000 \\
$\mathrm{C}$ & -1.828718000 & 4.595552000 & 33.494096000 \\
$\mathrm{C}$ & 0.380309000 & 12.394154000 & 32.862331000 \\
$\mathrm{C}$ & -0.064853000 & 9.276249000 & 25.873121000 \\
$\mathrm{C}$ & -0.181967000 & 4.860608000 & 29.594220000 \\
$\mathrm{C}$ & 5.860966000 & 10.602863000 & 36.471661000 \\
$\mathrm{C}$ & 0.481610000 & 11.472461000 & 27.019892000 \\
\hline & 9.626799000 & 10.400564000 & 35.115124000 \\
\hline
\end{tabular}




\begin{tabular}{lccc}
$\mathrm{C}$ & 11.947457000 & 9.928435000 & 34.288776000 \\
$\mathrm{C}$ & -0.148588000 & 2.899226000 & 33.338868000 \\
$\mathrm{C}$ & 13.387410000 & 6.632520000 & 29.203912000 \\
$\mathrm{C}$ & 1.939459000 & 5.595198000 & 28.524068000 \\
$\mathrm{C}$ & 0.313729000 & 10.259949000 & 31.562143000 \\
$\mathrm{C}$ & 8.318887000 & 7.296022000 & 26.087253000 \\
$\mathrm{C}$ & 1.593043000 & 12.234951000 & 30.683373000 \\
$\mathrm{C}$ & 12.906607000 & 4.793174000 & 32.931764000 \\
$\mathrm{C}$ & 4.529002000 & 12.996587000 & 27.364940000 \\
$\mathrm{C}$ & 9.353335000 & 12.155022000 & 30.693225000 \\
$\mathrm{C}$ & 0.079232000 & 7.240157000 & 28.879668000 \\
$\mathrm{C}$ & 1.649381000 & 7.724030000 & 25.231256000 \\
$\mathrm{C}$ & 6.763928000 & 5.042891000 & 35.554827000 \\
$\mathrm{C}$ & 4.399938000 & 6.721969000 & 25.388108000 \\
$\mathrm{C}$ & 11.787192000 & 2.714495000 & 28.919044000 \\
$\mathrm{C}$ & 0.879882000 & 10.113119000 & 26.469185000 \\
$\mathrm{C}$ & 8.280384000 & 1.031814000 & 27.049441000 \\
$\mathrm{C}$ & 4.687812000 & 9.053342000 & 24.490167000 \\
$\mathrm{C}$ & 9.526071000 & 0.449007000 & 26.850940000 \\
$\mathrm{C}$ & 9.783146000 & 9.917861000 & 26.188652000 \\
$\mathrm{C}$ & 10.634751000 & 1.003001000 & 27.478533000 \\
$\mathrm{C}$ & 8.589751000 & 1.400893000 & 31.159016000 \\
$\mathrm{C}$ & 10.548510000 & 11.322003000 & 30.206566000 \\
$\mathrm{C}$ & 2.492447000 & 7.876964000 & 36.383818000 \\
$\mathrm{C}$ & 13.125825000 & 8.972086000 & 28.365249000 \\
\hline & 0.739282000 & 3.795323000 & 32.740103000
\end{tabular}




\begin{tabular}{|c|c|c|c|}
\hline $\mathrm{C}$ & 0.315379000 & 5.125018000 & 32.492638000 \\
\hline $\mathrm{C}$ & 0.808869000 & 6.023859000 & 29.477195000 \\
\hline $\mathrm{C}$ & 11.016018000 & 8.651294000 & 36.233461000 \\
\hline $\mathrm{C}$ & 2.153250000 & 3.338336000 & 32.419532000 \\
\hline $\mathrm{C}$ & 5.968405000 & 11.619456000 & 35.526576000 \\
\hline $\mathrm{C}$ & 2.356560000 & 9.250785000 & 35.723588000 \\
\hline $\mathrm{C}$ & 10.524492000 & 2.114335000 & 28.317935000 \\
\hline $\mathrm{C}$ & 8.109934000 & 2.133959000 & 27.890780000 \\
\hline $\mathrm{C}$ & 10.203670000 & 11.688996000 & 27.747640000 \\
\hline $\mathrm{C}$ & 11.781624000 & 4.614264000 & 35.839116000 \\
\hline $\mathrm{C}$ & 9.550440000 & 4.730127000 & 36.698937000 \\
\hline $\mathrm{C}$ & 2.243064000 & 9.720648000 & 26.467642000 \\
\hline $\mathrm{C}$ & 3.661489000 & 10.023120000 & 35.608741000 \\
\hline $\mathrm{C}$ & 4.109484000 & 8.203884000 & 25.634849000 \\
\hline $\mathrm{C}$ & 12.593373000 & 5.955185000 & 33.885332000 \\
\hline $\mathrm{C}$ & 2.634932000 & 8.525625000 & 25.814014000 \\
\hline $\mathrm{C}$ & 5.004660000 & 13.051956000 & 33.654528000 \\
\hline $\mathrm{C}$ & 9.340506000 & 3.037189000 & 32.867515000 \\
\hline $\mathrm{C}$ & 7.765438000 & 6.193896000 & 35.724489000 \\
\hline $\mathrm{C}$ & 9.240911000 & 2.659795000 & 28.564133000 \\
\hline $\mathrm{C}$ & 10.160998000 & 9.398475000 & 28.519682000 \\
\hline $\mathrm{C}$ & 3.794549000 & 11.044243000 & 34.635647000 \\
\hline $\mathrm{C}$ & 10.300704000 & 10.778833000 & 28.804906000 \\
\hline $\mathrm{C}$ & 11.491210000 & 5.573336000 & 34.864335000 \\
\hline $\mathrm{C}$ & 9.860804000 & 8.962003000 & 27.206289000 \\
\hline $\mathrm{C}$ & 5.264643000 & 12.079461000 & 29.561868000 \\
\hline $\mathrm{C}$ & 12.851410000 & 8.036479000 & 29.547245000 \\
\hline
\end{tabular}




$\begin{array}{llll}\mathrm{C} & 6.971040000 & 3.081217000 & 32.036888000 \\ \mathrm{C} & 10.675506000 & 9.291802000 & 34.884574000 \\ \mathrm{C} & 1.184632000 & 11.464762000 & 31.948306000 \\ \mathrm{C} & 9.197592000 & 5.682512000 & 35.737692000 \\ \mathrm{C} & 4.947705000 & 11.866285000 & 34.604964000 \\ \mathrm{C} & 5.146239000 & 5.995508000 & 30.823462000 \\ \mathrm{C} & 1.441356000 & 6.463569000 & 30.811926000 \\ \mathrm{C} & 6.290767000 & 11.225073000 & 27.437347000 \\ \mathrm{C} & 8.812662000 & 3.916507000 & 30.583462000 \\ \mathrm{C} & 4.993703000 & 11.730076000 & 28.094983000 \\ \mathrm{C} & 8.439404000 & 2.850852000 & 31.635098000 \\ \mathrm{C} & 3.947293000 & 10.605176000 & 27.952408000 \\ \mathrm{C} & 10.186385000 & 6.125340000 & 34.828589000 \\ \mathrm{C} & 11.384917000 & 7.865618000 & 29.973320000 \\ \mathrm{C} & 4.850861000 & 6.313508000 & 32.162275000 \\ \mathrm{C} & 5.239221000 & 7.343725000 & 33.033538000 \\ \mathrm{C} & 6.043274000 & 8.495916000 & 32.920525000 \\ \mathrm{C} & 2.449785000 & 10.963850000 & 32.653906000 \\ \mathrm{C} & 5.932516000 & 6.571708000 & 29.807814000 \\ \mathrm{H} & 10.088125000 & 8.360392000 & 33.816283000 \\ \mathrm{C} & 6.731938000 & 7.733045000 & 29.677496000 \\ \mathrm{H} & 6.760887000 & 9.132529000 & 31.879732000 \\ \mathrm{H} & 7.022532000 & 8.843322000 & 30.515166000 \\ \mathrm{H} & 6.033733000 & 9.095663000 & 33.826930000 \\ \mathrm{H} & 7.156676000 & 10.0968553000 & 32.184264000 \\ \mathrm{H} & 4.749814000 & 7.286541000 & 34.001557000 \\ \mathrm{H} & 5.124451000 & 30.473490000\end{array}$




$\begin{array}{llll}\mathrm{H} & 7.532748000 & 9.646724000 & 29.989690000 \\ \mathrm{H} & 4.103308000 & 5.657043000 & 32.595809000 \\ \mathrm{H} & 7.099048000 & 7.876076000 & 28.665900000 \\ \mathrm{H} & 5.884043000 & 6.013700000 & 28.876533000 \\ \mathrm{H} & -3.610062000 & 6.616682000 & 32.567207000 \\ \mathrm{H} & -3.058155000 & 8.134867000 & 31.856932000 \\ \mathrm{H} & -2.751188000 & 6.602344000 & 31.023577000 \\ \mathrm{H} & -0.575191000 & 7.623552000 & 34.636070000 \\ \mathrm{H} & -1.843737000 & 8.701708000 & 34.020974000 \\ \mathrm{H} & -2.275750000 & 7.154841000 & 34.765911\end{array}$

\section{References}

(1) Eisenberger, P.; Ayinla, R. O.; Lauzon, J. M. P.; Schafer, L. L. Tantalum-Amidate Complexes for the Hydroaminoalkylation of Secondary Amines: Enhanced Substrate Scope and Enantioselective Chiral Amine Synthesis. Angew. Chem. Int. Ed. 2009, 48 (44), 8361-8365.

(2) Cantat, T.; Scott, B. L.; Kiplinger, J. L. Convenient Access to the Anhydrous Thorium Tetrachloride Complexes $\mathrm{ThCl}_{4}(\mathrm{DME})_{2}, \mathrm{ThCl}_{4}(1,4-\text { Dioxane })_{2}$ and $\mathrm{ThCl}_{4}(\mathrm{THF})_{3.5} \mathrm{Using}$ Commercially Available and Inexpensive Starting Materials. Chem. Commun. 2010, 46 (6), 919.

(3) Simpson, S. J.; Turner, H. W.; Andersen, R. A. Preparation and Hydrogen-Deuterium Exchange of Alkyl and Hydride Bis(Trimethylsilyl)Amido Derivatives of the Actinide Elements. Inorg. Chem. 1981, 20 (9), 2991-2995.

(4) Straub, M. D.; Hohloch, S.; Minasian, S. G.; Arnold, J. Homoleptic U(III) and U(IV) Amidate Complexes. Dalton Trans. 2018, 47 (6), 1772-1776.

(5) Oyala, P. H.; Ravichandran, K. R.; Funk, M. A.; Stucky, P. A.; Stich, T. A.; Drennan, C. L.; Britt, R. D.; Stubbe, J. Biophysical Characterization of Fluorotyrosine Probes SiteSpecifically Incorporated into Enzymes: E. Coli Ribonucleotide Reductase as an Example. J. Am. Chem. Soc. 2016, 138, 7951-7964.

(6) Stoll, S.; Schweiger, A. EasySpin, a Comprehensive Software Package for Spectral Simulation and Analysis in EPR. J. Magn. Reson. 2006, 178, 42-55.

(7) Thomson, R. K. Amidate Complexes of the Group 4 Metals: Synthesis, Reactivity, and Hydroamination Catalysis, University of British Columbia Dissertation, 2008. 
(8) Drover, M. W.; Love, J. A.; Schafer, L. L. 1,3-N,O-Complexes of Late Transition Metals. Ligands with Flexible Bonding Modes and Reaction Profiles. Chem. Soc. Rev. 2017, 46 (10), 2913-2940.

(9) Rausch, J.; Apostolidis, C.; Walter, O.; Lorenz, V.; Hrib, C. G.; Hilfert, L.; Kuehling, M.; Busse, S.; Edelmann, F. T. One Ligand Fits All : Lanthanide and Actinide Sandwich Complexes Comprising the 1,4-Bis(Trimethylsilyl)Cyclooctatetraenyl (=COT' ') Ligand. New J. Chem. 2015, 39, 7656-7666.

(10) Gaussian 09, Revision D.01, Frisch, M. J.; Trucks, G. W.; Schlegel, H. B.; Scuseria, G. E.; Robb, M. A.; Cheesman, J. R.; Scalmani, G.; Barone, V.; Mennucci, B.; Petersson, G. A.; Nakatsuji, H.; Caricato, M.; Li, X.; Hratchian, H. P.; Izmaylov, A. F.; Bloino, J.; Zheng, G.; Sonnenberg, J. L.; Hada, M.; Ehara, M.; Toyota, K.; Fukuda, R.; Hasegawa, J.; Ishida, M.; Nakajima, T.; Honda, Y.; Kitao, O.; Nakai, H.; Vreven, T.; Montgomery, J. A., Jr.; Peralta, J. E.; Ogliaro, F.; Bearpark, M.; Heyd, J. J.; Brothers, E.; Kudin, K. N.; Staroverov, V. N.; Kobayashi, R.; Normand, J.; Raghavachari, K.; A., R.; Burant, J. C.; Iyengar, S. S.; Tomasi, J.; Cossi, M.; Rega, N.; Millam, M. J.; Klene, M.; Knox, J. E.; Cross, J. B.; Bakken, V.; Adamo, C.; Jaramillo, J.; Gomperts, R.; Stratmann, R. E.; Yazyev, O.; Austin, A. J.; Cammi, R.; Pomelli, C.; Ochterski, J. W.; Martin, R. L.; Morokuma, K.; Zakrzewski, V. G.; Voth, G. A.; Salvador, P.; Dannenberg, J. J.; Dapprich, S.; Daniels, A. D.; Farkas, O.; Foresman, J. B.; Ortiz, J. V.; Cioslowski, J.; Fox, D. J., Gaussian Inc., 2009, Wallingford CT.

(11) (a) Becke, A. D. Density-Functional Thermochemistry. III. The Role of Exact Exchange. J. Chem. Phys. 1993, 98, 5648-5652 and references therein ; (b) Burke, K.; Perdew, J. P.; Yang, W. Electronic Density Functional Theory: Recent Progress and New Directions; Plenum: New York, 1998.

(12) (a) Dolg, M.; Stoll, H.; Preuss, H. J., Chem. Phys. 1989, 90, 1730-1734 ; (b) Cao, X.; Dolg, M., J. Molec. Struct.(Theochem), 2002, 581, 139-147.

(13) (a) Kuechle, W. ; Dolg, M. ; Stoll, H. ; Preuss, H. Energy-Adjusted Pseudopotentials for the Actinides. Parameter Sets and Test Calculations for Thorium and Thorium Monoxide, J. Chem. Phys. 1994, 100, 753 -7542; (b) Cao, X. ; Dolg, M. ; Stoll, H. Valence Basis Sets for Relativistic Energy-Consistent Small-Core Actinide Pseudopotentials. J. Chem. Phys. 2003, 118, 487-496; (c) Cao, X ; Dolg, M. Segmented Contraction Scheme for Small-Core Actinide Pseudopotential Basis Sets. J. Molec. Struct. (Theochem), 2004, 673, 203-209.

(14) (a) Hariharan, P. C.; Pople, J. A. The Influence of Polarization Functions on Molecular Orbital Hydrogenation Energies. Theor. Chem. Acc., 1973, 28, 213-222. (b) Hehre, W. J.; Ditchfield, R.; Pople, J. A. Self-Consistent Molecular Orbital Methods. XII. Further Extensions of Gaussian-Type Basis Sets for Use in Molecular Orbital Studies of Organic Molecules. J. Chem. Phys. 1972, 56, 2257-2261.

(15) Reed, A. E.; Curtiss, L. A.; Weinhold, F. Intermolecular Interactions from a Natural Bond Orbital, Donor-Acceptor Viewpoint. Chem. Rev. 1988, 88, 899-926. 
Disclaimer: This report was prepared as an account of work sponsored by an agency of the United States Government. Neither the United States Government nor any agency thereof, nor any of their employees, makes any warranty, express or implied, or assumes any legal liability or responsibility for the accuracy, completeness, or usefulness of any information, apparatus, product, or process disclosed, or represents that its use would not infringe privately owned rights. Reference herein to any specific commercial product, process, or service by trade name, trademark, manufacturer, or otherwise does not necessarily constitute or imply its endorsement, recommendation, or favoring by the United States Government or any agency thereof. The views and opinions of authors expressed herein do not necessarily state or reflect those of the United States Government or any agency thereof. 